$$
25
$$





\title{
Sytuacja demograficzna w Polsce Aspekty politologiczno-etyczne
}

\author{
Pod redakcją \\ Małgorzaty Pawlus \\ Mariusza Chamarczuka SDB
}

SPOTKANIA NAUKOWE WYKŁADOWCÓW

KATOLICKIEJ NAUKI SPOŁECZNEJ

Tom IX 
Opracowanie graficzne

Krystian Lipiński SDB

Skład

Mariusz Chamarczuk SDB

Korekta

Joanna Wójcik

Recenzenci:

Prof. UW dr hab. Krystyna Ostrowska

Ks. prof. zw. dr hab. Henryk Skorowski SDB

ISBN 978-83-61451-40-2

Wydawca:

Towarzystwo Naukowe Franciszka Salezego

Sekretariat:

ul. Baczyńskiego 1A

Skr. poczt. 26

05-095 Łomianki

E-mail: tnfs@tnfs.pl

www.tnfs.pl

Współpraca:

Wyższe Seminarium Duchowne Towarzystwa Salezjańskiego w Lązie nad Wartą

www.wsdts.pl; www.lad.pl

Międzyinstytutowy Zakład Badań nad Migracją UKSW www.migracje.uksw.edu.pl

Instytut Politologii UKSW

www.politologia.uksw.edu.pl 


\section{SPIS TREŚCI}

Wprowadzenie.

\section{Część I}

Współczesna sytuacja demograficzna w Polsce

\section{Irena Kowalska}

Procesy demograficzne w Polsce oraz uwarunkowania ich zmian

Ks. Piotr Mazurkiewicz

Kościół wobec wyzwań demograficznych

\section{Andrzej Ochocki}

Praca zawodowa kobiet jako czynnik zmiany demograficznej

\section{Małgorzata Pawlus}

Kobieta wielodzietna

\section{Magdalena Witkowska}

Przekonania i postawy prokreacyjne u osób świadomie wybierających wielodzietność

Tomasz Józefowicz

Polityka rodzinna w Polsce po 1989 roku

\section{Rafał Maciąg}

Aborcja z perspektywy personelu medycznego

Kinga Łapczys

Polskie podziemie aborcyjne: stan prawny - stan faktyczny 


\section{Część II \\ Opinie, relacje, sprawozdania świadectwa}

\section{Teresa Kapela}

Rodziny wielodzietne w Polsce .......................................2217

Anna Andrzejewska

Sytuacja polskiej rodziny w kontekście prowadzonej polityki rodzinnej

\section{Zuzanna Krogulec}

Wielodzietne rodziny uczestników Drogi Neokatechumenalnej

\section{Małgorzata Pawlus}

Sprawozdanie z konferencji Kościót wobec kryzysu demograficznego w Polsce w Falenicy w dniach 17-19 czerwca $2012 \mathrm{r}$.

\section{Ks. Mariusz Chamarczuk SDB}

Omówienie dyskusji z konferencji Kościół wobec kryzysu demograficznego w Polsce w Falenicy w dniach 17-19 czerwca 2012 r.

\section{Bożena Pietras}

Dom, rodzina - tu wszystko się zaczyna. Sprawozdanie z II Ogólnopolskiego Zjazdu Dużych Rodzin w Lublinie w dniach 20-22 czerwca 2014 r.

Ks. Mariusz Chamarczuk SDB, ks. Dominik Chmielewski SDB Świadectwa osób dojrzewających do świadomego macierzyństwa i ojcostwa we wspólnocie Nazaret przy duszpasterstwie akademickim UKSW

Aneks 1.

Teresa Kapela, Europejskie federacje stowarzyszeń rodzinnych, opracowanie własne

Aneks 2.

Kard. Andre Vingt Trois, Rodzina - szczęście, które trzeba zbudować, przemówienie wygłoszone podczas Kongresu Rodzin w Mediolanie 1-9.06.2012, tłum. T. Kapela. 


\section{Wprowadzenie}

Polska na początku transformacji systemowej w 1989 r. była krajem młodym o relatywnie wysokiej dzietności $(2,06)$. Jednym ze skutków zmiany warunków ekonomicznych, społecznych i kulturowych było odraczanie przez kobiety decyzji o macierzyństwie i gwałtowny spadek liczby urodzeń, że skutkiem czego na początku tego stulecia znaleźliśmy się w grupie państw o najniższej dzietności $(1,31)$. Z perspektywy dwóch kolejnych dekad sytuacja demograficzna jest jednym z głównych wyzwań rozwojowych ${ }^{1}$. Utrzymujące się w Polce niekorzystne procesy, takie jak bardzo niski poziom płodności i ujemne saldo migracji, oznaczają deformację struktury wiekowej i depopulację. W świetle najnowszej prognozy GUS, do $2050 \mathrm{r}$. liczba ludności zmniejszy się o 4,5 mln, a osoby w wieku 65 lat i więcej będą stanowiły $1 / 3$ populacji ${ }^{2}$. Spodziewana po 2004 r. znacząca odbudowa płodności związana z wchodzeniem w wiek prokreacji roczników wyżowych przełomu lat 70/80 nie nastąpiła, a proces wzmożonej emigracji ludzi młodych przyspieszył „drenaż młodości”. Już teraz, na skutek długotrwałego spadku urodzeń, w wiek prokreacji będą wchodziły coraz mniej liczne roczniki, a w 2050 r. liczba potencjalnych matek zmniejszy się o 40\% 3. Ponieważ przewidywany poziom reprodukcji ludności będzie daleki od prostej zastępowalności pokoleń, to na skutek dynamicznie postępującego procesu starzenia się (wzrost mediany wieku i odsetka osób starszych), w połowie XXI wieku Polska będzie jednym z najstarszych krajów UE. Zdaniem wielu ekspertów nie jest możliwe odwrócenie niekorzystnych trendów starzenia się społeczeństwa, ale można przygotować się na nadchodzące zmiany. Wzmacniać pozytywne, a osłabiać negatywne tendencje, inwe-

\footnotetext{
Por. Kancelaria Prezesa Rady Ministrów, Polska 2030. Wyzwania rozwojowe, Warszawa 2009, s. 47-51.

2 Por. GUS, Prognoza Ludności na lata 2014-2050, Warszawa 2014, s. 109.
}

3 Por. tamże.

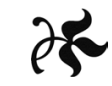


stować w przyszłość. W obliczu prognozowanych ekonomiczno-społecznych skutków starzenia się społeczeństwa, reformy systemu emerytalnego czy wzrost zatrudnienia i efektywności pracy są niewystarczające, by sprostać demograficznym wyzwaniom. Strategicznego znaczenia nabrała kwestia odbudowy płodności ${ }^{4}$.

Na poziom dzietności w Polsce mają wpływ czynniki ekonomiczne, kulturowe, prawne i systemowe. Sytuacja gospodarcza w kraju, poziom zamożności, warunki życia, stopa bezrobocia, stopień pewności zatrudnienia oraz wzrost aspiracji edukacyjnych i konsumpcyjnych pośrednio oddziałują na decyzje o posiadaniu dzieci. Jak pokazały ostatnie lata, to uwarunkowania społeczno-ekonomiczne przesądzają o wyborach młodych Polaków odnośnie do emigracji. Wyjeżdżają oni ze względu na wyższe zarobki i lepszy standard życia. Fenomenem ostatnich kilku lat jest fakt, iż w takich krajach jak Wielka Brytania, Niemcy, Norwegia, to właśnie młode Polki rodzą najwięcej dzieci spośród wszystkich imigrantek (współczynnik dzietności 2,1).

Celem polityki państwa jest tworzenie takich rozwiązań prawnych i systemowych, które zmniejszą koszty posiadania dzieci. W dyskursie publicznym w szczególności podnoszona jest kwestia tworzenia rozwiązań umożliwiających łączenie posiadania potomstwa $\mathrm{z}$ karierą zawodowa, np. poprzez zwiększenie dostępności placówek opiekuńczych $^{5}$. Jednakże, w odwołaniu do konstytucyjnej normy ochrony rodziny ${ }^{6}$, warunkiem sprzyjającym decyzjom małżeńskim i rodzicielskim jest możliwość zaplanowania przyszłości i zabezpieczenia godnego poziomu życia.

Niniejsza publikacja była zainspirowana ogólnopolską konferencją sekcji wykładowców katolickiej nauki społecznej „Kościół wobec kryzysu demograficznego w Pol-

\footnotetext{
Por tamże, s. 21.

Por. GUS, Prognoza, dz. cyt., s. 49-50.

Por. Konstytucja Rzeczypospolitej Polskiej z dnia 2 kwietnia 1997 r. Art. 18. Małżeństwo jako związek kobiety i mężczyzny, rodzina, macierzyństwo i rodzicielstwo znajdują się pod ochroną i opieką Rzeczypospolitej Polskiej.
} 
sce" (17-19 czerwca 2012 r., Falenica). Celem konferencji było zdiagnozowanie, jakie wyzwania stawia przed społeczeństwem obecna sytuacja demograficzna i jaka może być rola państwa i Kościoła w przeciwdziałaniu niekorzystnym trendom. W dyskusję, obok ekspertów oraz osób duchownych, włączyli się przedstawiciele rodzin wielodzietnych. Wydarzenie to wpisywało się w zorganizowany w 2012 r. II Kongres Demograficzny, który zapoczątkował powszechną debatę nad problemami demograficznymi w Polsce. Nasza książka jest wynikiem refleksji odnośnie do uwarunkowań i skutków obecnej sytuacji demograficznej w Polsce i wskazuje na potrzebę budowania szerokiego konsensusu w kwestii rodziny. Tworzenie środowiska sprzyjającego rozwojowi rodzin wymaga współpracy państwa, Kościoła i organizacji pozarządowych. Brak wsparcia ekonomicznego rodzin oraz wadliwe rozwiązania systemowe i prawne, nieuwzględniające zmieniających się uwarunkowań rodzicielstwa, powodują, iż mimo wysokiej akceptacji dla wartości rodzinnych, młodzi ludzie nie realizują planów prokreacyjnych, odraczają urodzenie dziecka i ograniczają liczbę potomstwa. Potrzeba nowej synergii oznacza społeczne dowartościowanie rodzicielstwa i zwiększenie pomocy dla rodzin wychowujących potomstwo, aby dzieci nie były traktowane jako kategoria dobra luksusowego, ale „dobro publiczne”, nie jako koszt, ale element budowy kapitału ludzkiego i społecznego oraz najlepsza inwestycja w przyszłość. Bo, parafrazując słowa Jana Pawła II, dziecko jest dobrem wspólnym każdej ludzkiej społeczności ${ }^{7}$.

Publikacja składa się z dwóch części, z których pierwsza ma charakter teoretyczno-empiryczny, natomiast druga jest bardziej zróżnicowana w formie - zawiera opinie, relacje, sprawozdania i świadectwa. Pierwszy z artykułów, autorstwa dr Ireny Kowalskiej, jest charakterystyką współczesnych procesów demograficznych w Polsce, wśród których szczególna uwaga jest poświęcona prze-

Jan Pawet II naucza o rodzinie, Kraków 2011, s. 41. 
mianom wzorca rodziny. Autorka analizuje czynniki, które oddziałują na dzietność rodzin i często stanowią barierę w podjęciu decyzji o pierwszym czy kolejnym dziecku.

Kolejny tekst ks. Piotra Mazurkiewicza to próba spojrzenia na wyzwania demograficzne $\mathrm{z}$ perspektywy nauczania społecznego Kościoła katolickiego. Autor w świetle wybranych dokumentów nauczania Kościoła wskazuje, iż nauczycielska rola Magisterium polega, z jednej strony, na wskazywaniu oraz piętnowaniu negatywnych tendencji i działań takich jak: koncepcje neomaltuzjańskie oraz polityki antynatalistyczne sprzężone $\mathrm{z}$ deprecjonowaniem małżeństwa i rodziny. Z drugiej strony, misją Kościoła jest promowanie idei i zachowań służących dobru wspólnemu oraz poszanowaniu godności człowieka w odniesieniu m.in. do takich kwestii, jak natura relacji między mężczyzna i kobietą czy znaczenie ludzkiej płodności.

Andrzej Ochocki w swoim artykule, w nawiązaniu do teorii dzietności Gary S. Beckera, analizuje współzależności decyzji matrymonialnych, prokreacyjnych i aktywności zawodowej kobiet oraz rzeczywistego przebiegu procesu zastępowalności pokoleń w pięciu państwach: Finlandii, Niemczech, Polsce, Republice Czeskiej i Włoszech. Ponadto Autor prezentuje kluczowe rozwiązania propagowane w politykach rodzinnych krajów europejskich, których celem jest zarówno podniesienie dzietności, jak i zwiększenie zatrudnienia kobiet.

Następny artykuł, autorstwa Małgorzaty Pawlus, poświęcony jest charakterystyce kobiet wielodzietnych w odniesieniu do danych statystycznych oraz społecznoekonomicznych modeli macierzyństwa i rodziny. Przedstawiony jest trend zaniku rodzin wielodzietnych w kontekście zmieniających się preferencji kobiet odnośnie do wielkości rodziny, ale również zewnętrznych czynników ograniczających dzietność.

Z kolei, Magdalena Witkowska, w oparciu o przeprowadzone badania jakościowe, przedstawia przekonania i postawy prokreacyjne osób świadomie wybierających wielodzietność. W pierwszej kolejności opisuje zmiany 
w ilości i sytuacji rodzin wielodzietnych, które dokonały się pomiędzy dwoma ostatnimi spisami powszechnymi (2002 i 2011 r.). Następnie wyjaśniania zastosowane w badaniu podejście teoretyczne (Teoria Planowanego Zachowania I. Ajzena), metodologię oraz uzyskane w trakcie wywiadów pogłębionych wyniki, które mogą być pomocne w wyodrębnieniu czynników sprzyjających większej dzietności.

Tekst Tomasza Józefowicza dotyczy rozwoju polityki państwa względem rodzin po roku 1989. Autor, w oparciu o wybrane dokumenty rządowe i sejmowe, analizuje, jak była ona formułowana i realizowana przez poszczególne rządy w różnych okresach polskiej transformacji ustrojowej. Ponadto zwraca uwagę na aspekt normatywny polityk rodzinnych, kwestię ich zgodności z system społecznych wartości.

Dwa ostatnie artykuły z części pierwszej podejmują problematykę aborcji. Przyjęta w 1993 r. Ustawa o planowaniu rodziny, ochronie płodu ludzkiego i warunkach dopuszczalności przerywania cią̇̇y, która zniosła możliwość dokonywania aborcji z przyczyn społecznych, w założeniu miała przyczynić się do wzrostu liczby urodzeń. Tak się jednak nie stało, a istniejące podziemie aborcyjne wskazuje na poważny społeczny problem naruszania obowiązujących przepisów. Rafał Maciąg, w oparciu o wywiady pogłębione, prezentuje zjawisko aborcji z perspektywy personelu medycznego, natomiast Kinga Łapczys, poprzez zbadanie wybranych prasowych i internetowych ogłoszeń aborcyjnych, sprawdza dostępność tych nielegalnych usług. Autorzy wskazują na wzrost częstości stosowania farmakologicznego utrudniania zajścia w ciążę oraz jej przerywania po stosunku seksualnym.

Część drugą publikacji rozpoczyna tekst Teresy Kapeli, współzałożycielki Związku Dużych Rodzin „Trzy Plus”. Podjęte zostają takie kwestie jak: założenia programowe stowarzyszeń rodzinnych funkcjonujących w Europie, stereotypy i realia dotyczące rodziny wielodzietnej w Polsce, zmiana społecznego wizerunku dużych rodzin, które mogą być rozwiązaniem problemów demograficz- 
nych Europy. Anna Andrzejewska, również reprezentująca Związek, poddaje krytycznej ocenie wybrane zapisy ustaw, które mają wpływ na sytuacje rodzin, a zarazem nie są adekwatne do ich potrzeb i praw.

Artykuł Zuzanny Krogulec wyjaśnia fenomen wielodzietności uczestników katolickiego ruchu religijnego Droga Neokatechumenalna, zwracającuwagę na takie czynniki, jak przykład innych rodzin oraz formacja ukierunkowana na prowadzenie chrześcijańskiego życia rodzinnego, którego ważnym aspektem jest „otwartość na życie”.

Następne w kolejności są trzy teksty w formie sprawozdania. Małgorzata Pawlus streszcza tematykę ogólnopolskiej konferencji sekcji wykładowców katolickiej nauki „Kościół wobec kryzysu demograficznego w Polsce”, która odbyła się w dniach17-19 czerwca 2012 r. w Falenicy. Natomiast ks. Mariusz Chamarczuk przedstawia omówienie bogatejmerytorycznie dyskusji, która stanowiłauzupełnienie referentów konferencyjnych. Ostatnie ze sprawozdań przygotowane przez Bożenę Pietras przewodniczącą koła lubelskiego ZDR „Trzy Plus” dotyczy II Ogólnopolskiego Zjazdu Dużych Rodzin, który miał miejsce w Lublinie w dniach 20-22 czerwca 2014 r. Kolejnym tekstem, zredagowanym przez ks. Mariusza Chamarczuka SDB i ks. Dominika Chmielewskiego SDB, są świadectwa osób działających w duszpasterstwie akademickim UKSW (wspólnota Nazaret) i podejmujących świadomy proces kształtowania postaw macierzyńskich i ojcowskich. Książkę kończą dwa Aneksy opracowane przez Teresę Kapelę. Pierwszy zawiera informację o europejskich federacjach stowarzyszeń rodzinnych, a drugi to przemówienie Kard. Andre Vingt Trois, Rodzina - szczęście, które trzeba zbudować, wygłoszone podczas Kongresu Rodzin w Mediolanie 1-9 czerwca 2012 r. 


\section{Część I}

\section{WSPÓŁCZESNA SYTUACJA \\ DEMOGRAFICZNA W POLSCE}





\section{Irena Kowalska}

\section{Procesy demograficzne w Polsce oraz uwa- runkowania ich zmian}

\section{Wprowadzenie}

Od wielu lat coraz częściej pojawiają się głosy niepokoju o przyszłość demograficzną Europy oraz o miejsce małżeństwa i rodziny w zapewnieniu pożądanego rozwoju ludnościowego. Niepokój ten dotyczy również naszego społeczeństwa. Symptomem notowanych przeobrażeń są niekorzystne trendy $\mathrm{w}$ tworzeniu rodzin i ich funkcjonowaniu, powodowane różnorodnymi czynnikami. Obok uwarunkowań ekonomicznych dostrzeganych zmian, najczęściej wymieniana jest ewolucja w systemie norm i wartości współczesnych społeczeństw. Wśród nich za istotny czynnik uznaje się brak odpowiedniego szacunku dla rodzin oraz daleką od pożądanej skalę ich wspierania poprzez odpowiednie rozwiązania ustawodawcze i wykonawcze. Główne oznaki notowanych przeobrażeń w sferze demografii to: postępujący spadek dzietności, wzrost udziału nieformalnych związków zastępujących pary małżeńskie i idąca w ślad za tym rosnąca liczba dzieci pozamałżeńskich, dezintegracja małżeństw, której wyrazem jest systematyczny wzrost liczby rozwodów.

Obraz sytuacji demograficznej kraju w nowym stuleciu nie daje powodów do optymizmu. Musi niepokoić zarówno fakt zanikania biologicznej substancji narodu, co może zadecydować o polskim „być” albo „nie być”, jak i załamywanie się najważniejszej funkcji prokreacyjnej rodzin, świadczące o ich trudnościach przystosowawczych i niewydolności. W 2013 r. na 100 kobiet przypadało średnio 126 urodzeń, podczas gdy do zachowania prostej zastępowalności pokoleń potrzeba minimum 211. 
To oznacza nieuniknioną depopulację, czyli systematyczne zmniejszanie się liczby mieszkańców kraju, obecnie o 40\%. Obok ujemnego salda urodzeń wobec zgonów, równego 17,7 tys., składa się na nią również nadwyżka liczby osób opuszczających kraj nad przybywającymi do Polski. Od 2011 roku ich ubytek wyniósł 53,6 tys. Emigracja jest powodowana różnymi czynnikami: wśród nich do najważniejszych należy niedostatek miejsc pracy w kraju, niemożliwe do przekroczenia bariery w zdobyciu mieszkania przez młode rodziny, brak perspektyw na godne życie wobec postępującego zróżnicowania społeczeństwa i jego podziału na milionerów i nęd zarzy. Trudno godzić się z tym, że kraj opuszczają ludzie młodzi i życiowo zaradni, którzy mogliby pracować dla dobra ojczystego kraju.

Od wieków polskie wzorce tworzenia rodzin i ich funkcjonowania były przykładem do naśladowania ze względu na odpowiedzialność i szacunek dla osób najbliższych, niezależnie od ich wieku, warunków materialnych i pozycji społecznej. We współczesnych rankingach dotyczących przemian rodziny oraz ich uwarunkowań kwestionowane są nie tylko tradycyjne wzorce życia rodzinnego, zmieniające się pod naciskiem przemian społecznych i nowych warunków pracy, ale atakowana jest sama koncepcja rodziny jako wspólnoty osób, której podstawę stanowi małżeństwo kobiety i mężczyzny. Trudno polemizować z teza, że osłabienie rodziny w dużym stopniu jest powodowane kryzysem małżeństwa. Nie sposób również nie zgodzić się z twierdzeniem, że w sytuacji, gdy rodziny tracą swą tożsamość i nie wypełniają podstawowych funkcji, przestają tworzyć bezpieczne środowisko dla miłości i życia, a dzieci i młodzież nie znajdują wsparcia wśród dorosłych w procesie kształtowania indywidualnych i społecznych postaw i zachowań. Ostatecznie słabnie całe społeczeństwo. Wyzwaniem dla podejmowanych prorodzinnych działań jest troska o zachowanie istniejącego od wieków modelu rodzin z obojgiem rodziców i dziećmi poprzez szacunek dla nich oraz wspieranie ich w potrzebie. Odpowiedzialność za stworzenie rodzinom 
odpowiednich warunków życia ponosi całe społeczeństwo; ustalanie instrumentów niezbędnego wspierania należy do władz ustawodawczych i wykonawczych.

\section{Procesy demograficzne w Polsce w latach 2000-2013}

\section{Ludność Polski w latach 2000-2013 i jej zmiany}

Według wyników ostatniego spisu ludności, w dniu 31 marca 2011 r. ludność Polski liczyła 38501 tys. mieszkańców, tj. o 0,8\% więcej w stosunku do stanu w końcu 2010 r. Po jedenastoletnim okresie (obejmującym lata 1997-2007) niekorzystnego trendu zmniejszania się liczby ludności kraju w wyniku niskiego przyrostu naturalnego oraz ujemnego salda stałych migracji zagranicznych, cztery ostatnie lata przyniosły pozytywne zmiany obu wielkości. Według danych Głównego Urzędu Statystycznego, po kolejnych latach 2006-2012, w których liczba urodzeń przewyższyła o 132,2 tys. liczbę zgonów, w 2013 r. zanotowano ujemne saldo urodzeń wobec zgonów równe 17,7 tys.; w wyrażeniu względnym przeciętnie na każde 10 tys. ludności ubyło 5 osób. W miastach ujemne saldo wynosiło 21,3 tys. osób, a na wsi przybyło 3,6 tys.; w przeliczeniu na 10 tys. w pierwszej grupie ubyło 9 osób, a w drugiej - przybyły 2 osoby. Zmiany przyrostu naturalnego w latach 1946-2009 prezentuje wykres 1.

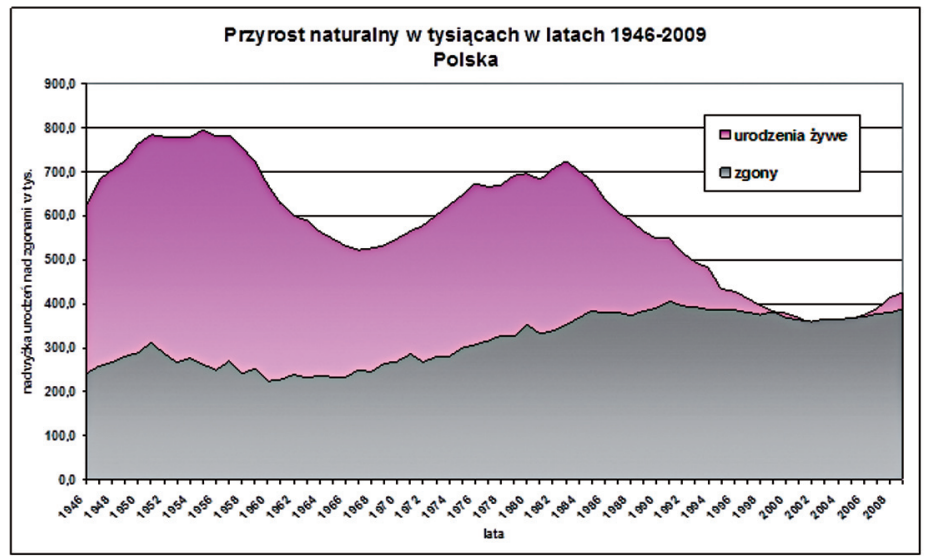


Wykres 1.

Urodzenia żywe w latach 2010-2013

2010 r.: urodzenia żywe - 413,3 tys.; zgony - 378,5 tys.; nadwyżka urodzeń $-34,0$ tys.

2011 r.: urodzenia żywe - 388,4 tys.; zgony - 375,5 tys.; nadwyżka urodzeń - 12,9 tys.

2012 r.: urodzenia żywe - 386,3 tys.; zgony - 384,8 tys.; nadwyżka urodzeń - 1,5 tys.

2013 r.: urodzenia żywe - 369,6 tys.; zgony - 387,3 tys.; nadwyżka zgonów - 17,7 tys.

Jednocześnie, notowane od 1960 r. ujemne saldo migracji zagranicznych i jego wyjątkowo wysoki poziom w 2006 r., równy 36,1 tys., w ostatnich latach wyraźnie się zmniejszał. Na przełomie dekad liczba osób wyjeżdżających za granicę przewyższyła o 6,4 tys. liczbę imigrantów, w dwu ostatnich latach 2012-2013 ujemne saldo wyniosło łącznie 26,5 tys.: w tym 19,1 tys. w miastach i 7,4 tys. na wsi.

\section{Przeciętne dalsze trwanie życia w latach $1970-2013$}

Od 1980 r. przeciętne dalsze trwanie życia kobiet i mężczyzn mierzone średnią liczbą lat, jakie ma do przeżycia noworodek, wydłuża się, przy czym kobiety żyją znacznie dłużej niż mężczyźni. W 2013 r. analizowany wskaźnik dla kobiet wyniósł 81,1 roku, a dla mężczyzn 73,1; dla porównania - w 2005 r. parametry te wynosiły odpowiednio 79,4 oraz 70,8. Notowane różnice wynikają głównie z odmiennego trybu życia i ze starań o zdrowie obu płci. Alkoholizm i palenie papierosów jest w grupie mężczyzn znacząco bardziej rozpowszechnione niż wśród kobiet i uznawane jest za główny czynnik różnic w poziomie analizowanego wskaźnika. Trendy zmian przeciętnego dalszego trwania życia w latach 1970-2008 prezentuje wykres 2. 
Wykres 2.

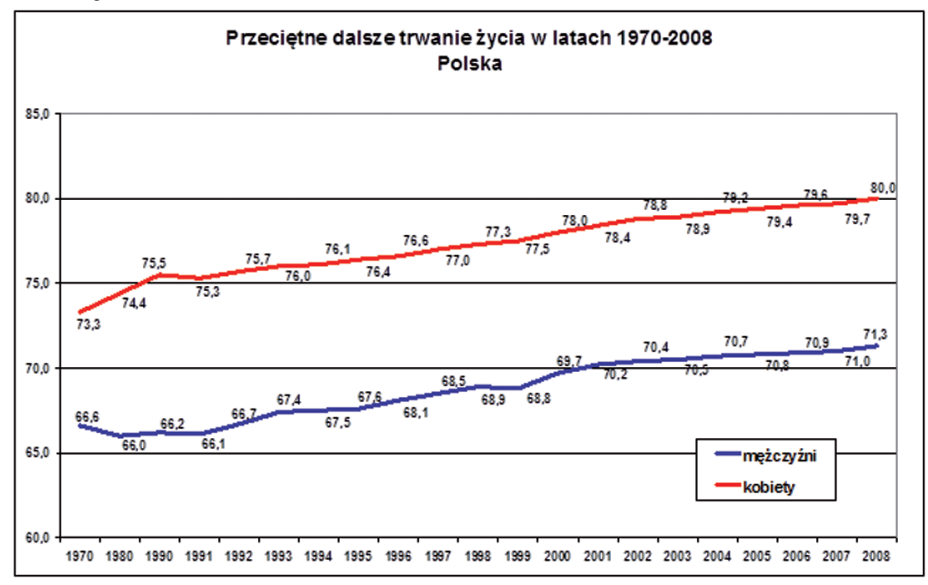

Przeciętne dalsze trwanie życia w latach 2009-2013

\section{LATA}

2009 r.

2010 r.

2011 r.

2012 r.

2013 r.
KOBIETY

80,1 roku

80,6 roku

80,9 roku

81,0 lat

81,1 roku
MĘŻCZYŹNI

71,5 roku;

72,1 roku;

72,4 roku;

72,7 roku

73,1 roku.

Warto w tym miejscu wspomnieć, że pozytywne trendy wydłużania się przeciętnego trwania życia zaowocują w przyszłości wzrostem populacji osób sędziwych, w wieku 80 lat i starszych. Osoby te będą wymagały wzmożonej, codziennej opieki, a nierzadko również intensywnej opieki lekarskiej. Wobec dynamicznego starzenia się ludności w wieku produkcyjnym i idącej z nim w parze redukcji podaży zasobów pracy z jednej strony, a z drugiejistotnej redukcji populacji młodego i średniego pokolenia można oczekiwać poważnych trudności w zapewnieniu takiej opieki osobom jej potrzebującym. 


\section{Zmiany w strukturze ludności według wieku w latach 1970-2013}

Istota przemian stanu i struktury ludności przejawia się głównie w zmianach udziału osób najmłodszych (w wieku poniżej 15 lat) oraz seniorów (w wieku 65 lat i więcej) w ogólnej liczbie mieszkańców kraju. Pierwszą z grup można uznać za wnuków, drugą - za dziadków. W demografii za starzejące uznaje się społeczeństwa, w których odsetek seniorów przekracza 13\% ogółu ludności.

W Polsce do 1988 r. odsetek osób należących do najmłodszej generacji pozostawał na niemal niezmienionym poziomie: jego krańcowe wielkości wahały się od 26,5\% w 1970 r. do 23,8\% w sześć lat później. Po osiągnięciu maksymalnej wysokości 25,7 \% w 1986 r., analizowana proporcja zmniejszała się systematycznie do poziomu 15,1\% w 2010 r. Jednocześnie z roku na rok zwiększał się udział osób starszych (seniorów) w wieku 65 lat i więcej; skalę zmian wyznaczały odsetki od 9,4\% w latach 19841985 do 13,5\% w trzech przedostatnich latach 2008-2010 oraz do 14,7\% w roku 2013.

Z przytoczonych liczb wynika, że w 1984 r. na 100 dzieci przypadało średnio 37 osób starszych, w 2010 r. proporcja ta wynosiła 89 na 100 . Trzy pierwsze lata nowej dekady wskazują na rosnący wzrost różnic w odsetkach seniorów w stosunku do proporcji dzieci i młodzieży. W 2011 r. na 100 dzieci przypadało 91 osób w wieku 65 lat i więcej, w 2012 - 95, a w 2013 - 98. Graficznym obrazem zmian liczby i struktury ludności w latach 1979-2009 jest poniższy wykres. 
Wykres 3.

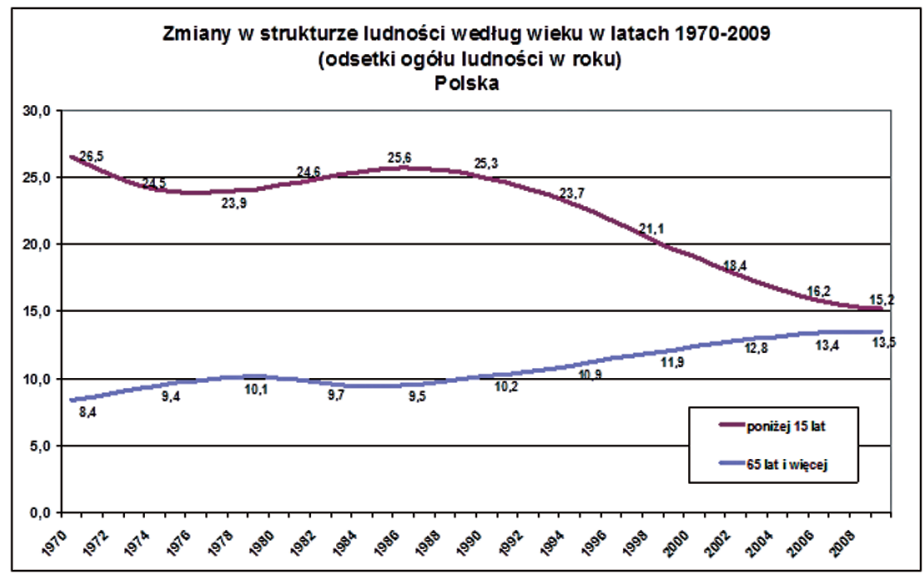

Odsetek ludności w wieku poniżej 15 lat w latach: LATA

2010 r. $-15,2 \%$;

2011 r. $-15,1 \%$;

2012 r. $-15,0 \%$

2013 r. $-15,0 \%$

Odsetek ludności w wieku 65 lat i więcej w latach:

\section{LATA}

2010 r. $-13,5 \%$;

2011 r. $-13,8 \%$;

2012 r. $-14,2 \%$

2013 r. $-14,7 \%$

Według najnowszej prognozy ludności Polski, w 2030 r. w kraju będzie mieszkać 37185 tys. osób, w tej liczbie znajdzie się 8646 tys. osób w wieku powyżej 65 lat, nazywanym wiekiem poprodukcyjnym, oraz 5211 tys. dzieci i młodzieży w wieku 15 lat i młodszych, określanych mianem przedprodukcyjnym. Populacja osób w wieku produkcyjnym będzie liczyć 23328 tys. osób. W myśl przewidywań, udział najmłodszych mieszkańców w całej populacji wyniesie $14,0 \%$, a najstarszych $-23,3 \%$; 
z porównania obu wielkości wynika, że na 100 osób młodych przypadnie średnio 166 seniorów.

\section{Dzietność rodzin w latach 1970-2013}

Po okresie systematycznego obniżania liczby urodzeń w latach 1951-1967 od 763,1 tys. do 521,8 tys., od 1968 r. do 1983 r. notowano jej systematyczny wzrost do maksymalnej wielkości 723,6 tys. W kolejnych latach dzietność kobiet systematycznie zmniejszała się do najniższego poziomu 351,1 tys. w 2003 r.; od 2004 r. do 2009 miał miejsce postępujący wzrost liczby rodzonych dzieci do 417,6 tys., tj. o 18,9\% więcej niż w roku 2003. W 2010 r. liczba urodzeń zmniejszyła się do 413,3 tys., a w rok później - do 391,0 tys., co w wyrażeniu względnym oznacza spadek o 6,4\%. W pierwszych trzech latach nowej dekady (tj. w latach 2011-2013) przyszło na świat łącznie 1144,3 tys. dzieci. Ich liczba w kolejnych latach zmniejszała się z 388,4 tys. w pierwszym roku do 386,3 tys. rok później i 369,6 tys. w roku 2013; w wyrażeniu względnym łączna redukcja wyniosła 5,0\%. Szczegółowe dane o liczbie urodzeń w kolejnych latach przedstawia poniższe zestawienie:

Urodzenia żywe w latach 2009-2013 - liczby absolutne w tysiącach:

$\begin{array}{llll}\text { LATA } & \text { POLSKA } & \text { MIASTA } & \text { WIEŚ } \\ 2009 & 417,6 & 246,4 & 171,2 \\ 2010 & 413,3 & 241,9 & 171,4 \\ 2011 & 388,4 & 225,7 & 162,7 \\ 2012 & 386,3 & 223,7 & 162,6 \\ 2013 & 369,6 & 213,8 & 155,8\end{array}$




\begin{tabular}{|c|c|c|c|}
\hline \multicolumn{4}{|c|}{$\begin{array}{l}\text { Urodzenia żywe w latach } 2009-2013 \text { - odsetki o } \\
\text { urodzeń: }\end{array}$} \\
\hline LATA & POLSKA & MIASTA & WIEŚ \\
\hline 2009 & 100,0 & 59,0 & 41,0 \\
\hline 2010 & 100,0 & 58,5 & 41,5 \\
\hline 2011 & 100,0 & 58,1 & 41,9 \\
\hline 2012 & 100,0 & 57,9 & 42,1 \\
\hline 2013 & 100,0 & 57,8 & 42,2 \\
\hline
\end{tabular}

Trendy zmian liczby urodzeń zależą zarówno od liczby kobiet $\mathrm{w}$ wieku rozrodczym, jak i natężenia urodzeń. Miarą zastępowalności pokoleń jest średnia liczba dzieci żywych urodzonych przez matkę w wieku 15-49 lat, określana mianem współczynnika dzietności. Z prostą zastępowalnością pokoleń mamy do czynienia wówczas, gdy jedna matka pozostawia po sobie jedną córkę; ta - po osiągnięciu dorosłości - zastąpi ją w tworzeniu nowej generacji. Z uwagi na zbliżone prawdopodobieństwo urodzenia chłopca i dziewczynki prosta zastępowalność wymaga od matki urodzenia średnio przynajmniej dwojga dzieci, a mając na uwadze fakt, że nie wszystkie kobiety zostają matkami, dopiero liczba 211 żywo urodzonych dzieci na 100 kobiet zapewnia prostą odtwarzalność generacji.

Tymczasem, od 1989 r., w którym na 100 kobiet przypadło 207 dzieci, nowa generacja Polaków jest mniej liczna od ustępującej. Do 2000 r. adekwatna proporcja systematycznie zmniejszała się do poziomu 137 urodzeń na 100 kobiet; w 2010 r. na 100 kobiet przypadło średnio 138 dzieci, co oznacza zastępowalność ustępującej generacji jedynie $\mathrm{w}$ niespełna dwu trzecich. $W$ kolejnych latach nowej dekady adekwatne proporcje wynosiły po 130 w roku 2011 i 2012 oraz 126 w roku 2013. Reasumując, od ponad 20 lat w kraju utrzymuje się depresja urodzeń, co znajduje wyraz w malejącej liczbie ludności kraju. Informacje o poziomie współczynników dzietności oraz ich zmianach prezentuje wykres 4 oraz zestawienie danych pod nim zawarte. 
Wykres 4.

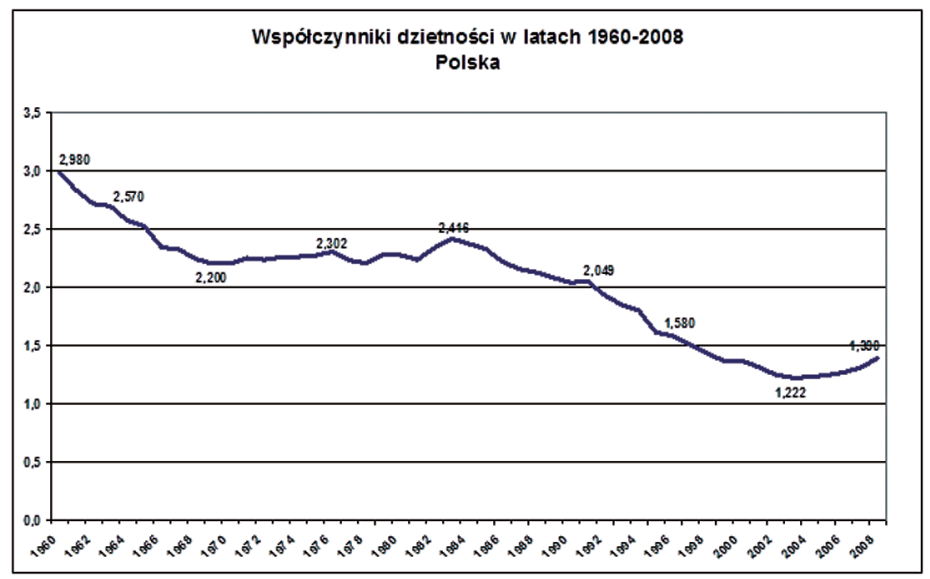

Współczynniki dzietności w latach 2009-2013

$\begin{array}{llll}\text { LATA } & \text { POLSKA } & \text { MIASTA } & \text { WIEŚ } \\ 2009 & 1,398 & 1,330 & 1,496 \\ 2010 & 1,382 & 1,309 & 1,489 \\ 2011 & 1,297 & 1,211 & 1,427 \\ 2012 & 1,299 & 1,212 & 1,427 \\ 2013 & 1,256 & 1,176 & 1,370\end{array}$

Niska dzietność wynika z ograniczania planów rodzicielskich do jednego dziecka lub co najwyżej dwojga. Bogatszym decyzjom nie sprzyja sytuacja na rynku pracy, na którym popyt na pracę jest znacząco mniejszy od podaży. Ponadto matka z małym dzieckiem - mimo ostatnio ustalonego prawa do płatnego pozostania $\mathrm{z}$ nim $\mathrm{w}$ domu w pierwszym roku jego życia - jest często niechętnie widziana $\mathrm{w}$ miejscu pracy po powrocie $\mathrm{z}$ rocznego urlopu macierzyńskiego z uwagi na większe prawdopodobieństwo korzystania ze zwolnień lekarskich w związku z ewentualną chorobą dziecka czy mniejsze zaangażowanie $\mathrm{w}$ pracę. Brak miejsc w przedszkolach przy jednoczesnym braku funduszy na zatrudnienie opiekunki dla dziecka zmusza kobietę do pozostania z dzieckiem $\mathrm{w}$ domu, a niskie świadczenia rodzinne nie są $\mathrm{w}$ sta- 
nie zabezpieczyć rodziny pod względem finansowym. W grupie pozamaterialnych uwarunkowań istotnym czynnikiem ograniczania dzietności dla potencjalnych, młodych rodziców jest m.in. stawianie na edukację i nieustanne dokształcanie, osiaganie awansów w pracy oraz posiadanie czasu dla siebie.

\section{Współczynnik reprodukcji brutto}

Jest to miara ściśle związana ze współczynnikiem dzietności. Określa bowiem średnią liczbę córek rodzonych przez kobiety przy założeniu, że kobieta w wieku rozrodczym będzie rodzić z częstością jaką charakteryzują się wszystkie kobiety w roku. Proporcje płci męskiej i żeńskiej noworodków są zbliżone, aczkolwiek udział chłopców jest nieco wyższy (stanowią oni około 51,3\% ogółu noworodków). Nieznaczące dysproporcje wyrównuje wyższe ryzyko zgonów noworodków i niemowląt płci męskiej. Pochodną współczynnika reprodukcji brutto jest współczynnik reprodukcji netto, który określa liczbę córek - przypadających na jedną kobietę - pomniejszoną o córki, które nie dożyją wieku swoich matek. Współczynnik ten wyraża stopień zastępowania pokoleń matek przez córki. Dzisiaj urodzone córki zastąpią w przyszłości swoje matki w procesie odnawialności pokoleń. Jeśli na jedną matkę przypadłaby minimum jedna córka, mielibyśmy prostą zastępowalność pokoleń. Ale na takie proporcje się nie zanosi. Dzisiaj na 100 matek przypada średnio 66 córek, a skoro prawdopodobieństwo powiększenia tej proporcji w najbliższej przyszłości jest niemożliwe, kolejne pokolenie może zmniejszyć się do około dwu trzecich obecnego stanu ludności. Trendy współczynnika reprodukcji brutto prezentuje wykres 5; nietrudno zauważyć, że są one zbieżne z kierunkiem zmian współczynnika dzietności, zamieszczonym na wykresie 4 . 
Wykres 5.

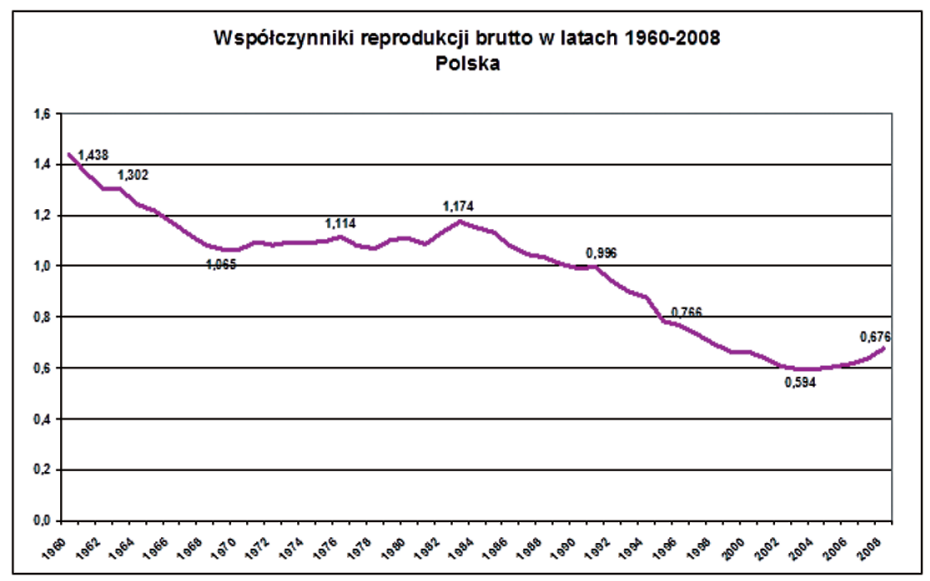

Współczynniki reprodukcji brutto w latach 2009-2013:

$\begin{array}{llll}\text { LATA } & \text { POLSKA } & \text { MIASTA } & \text { WIEŚ } \\ 2009 & 0,678 & 0,645 & 0,726 \\ 2010 & 0,665 & 0,631 & 0,713 \\ 2011 & 0,660 & 0,587 & 0,694 \\ 2012 & 0,631 & 0,589 & 0,963 \\ 2013 & 0,611 & 0,571 & 0,668\end{array}$

\section{Urodzenia pozamałżeńskie}

Wyrazem negatywnych zmian notowanych we wzorcu tworzenia rodzin i ich funkcjonowaniu są również trendy zmian w liczbie urodzeń pozamałżeńskich. Wprawdzie w naszym kraju ich udział w ogólnej liczbie urodzeń jest znacząco niższy w zestawieniu ze stanem w innych krajach, niemniej jednak nie sposób nie dostrzec, że od 2000 r., w którym urodzenia pozamałżeńskie w kraju ogółem stanowiły 12,1\% ogółu urodzeń żywych, w tym $14,4 \%$ w miastach i 8,8\% na wsi, do 2010 r. analizowane odsetki powiększyły się do 20,6\% w całym kraju, w tym do $23,2 \%$ w miastach oraz do $17,0 \%$ na wsi. W 2013 r. na 1000 urodzeń ogółem przypadało przeciętnie 234 urodzeń pozamałżeńskich, w tym 257 w miastach i 202 na wsi. Z załączonych liczb wynika, że dynamika wzrostu odset- 


\section{Część I}

Współczesna sytuacja demograficzna w Polsce

ka w latach 2010-2013 była na wsi szybsza niż w miastach; o ile w miastach zanotowano wzrost odsetka o $61 \%$, o tyle na wsi - o 93\%. Zmiany absolutnej liczby urodzeń pozamałżeńskich oraz ich udziału w urodzeniach ogółem prezentują wykresy 6a i 6b.

Wykres 6a.

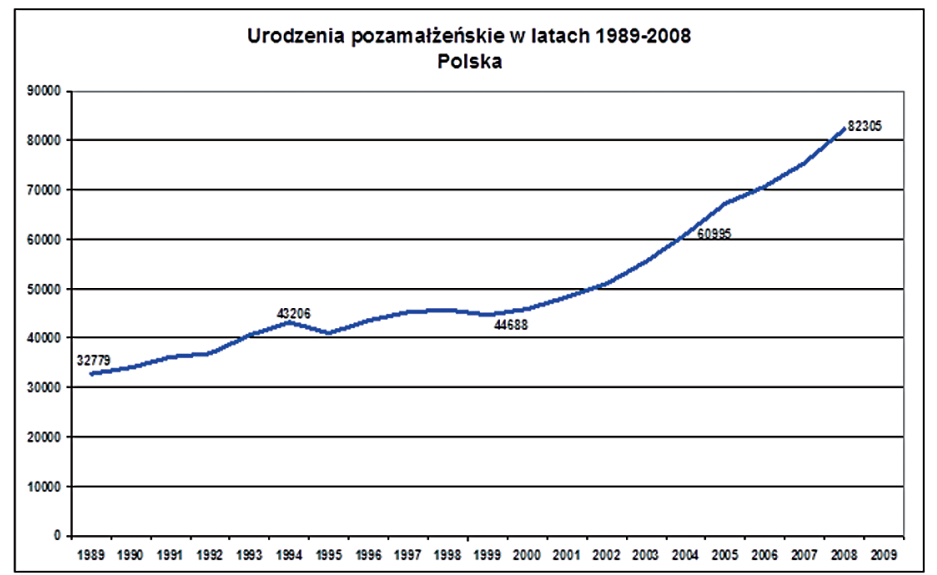

Urodzenia pozamałżeńskie w latach 2009-2013 - liczby absolutne w tys.

$\begin{array}{llll}\text { LATA } & \text { POLSKA } & \text { MIASTA } & \text { WIEŚ } \\ 2009 & 84,5 & 56,5 & 28,0 \\ 2010 & 85,1 & 55,9 & 29,2 \\ 2011 & 82,4 & 53,3 & 29,1 \\ 2012 & 86,3 & 55,5 & 30,8 \\ 2013 & 86,5 & 55,0 & 31,5\end{array}$


Wykres 6b.

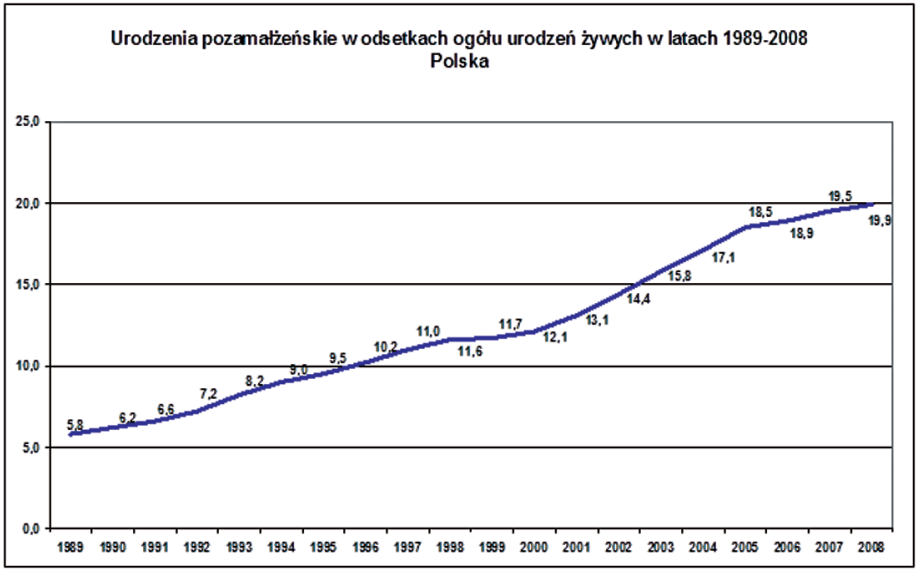

Urodzenia pozamałżeńskie w latach 2009-2013 - odsetki ogółu urodzeń żywych:

LATA

2009

2010

2011

2012

2013
POLSKA

20,2

20,6

21,2

22,3

23,4
MIASTA

22,9

23,1

23,6

24,8

25,7
WIEŚ

16,4

17,0

17,9

19,0

20,2

\section{Rodzina w Polsce}

Podstawę tworzenia rodziny stanowi związek małżeński kobiety i mężczyzny, zawarty tylko w urzędzie stanu cywilnego (ślub cywilny), w kościele (ślub wyznaniowy) lub zarówno w urzędzie, jak i w kościele. Zdecydowana większość par nowożeńców w naszym kraju wybiera związki wyznaniowe. W 2010 r. ich udział w skali kraju wynosił $68 \%$, w kolejnych latach adekwatny odsetek nie różnił się znacząco. Wprawdzie powiększająca się z roku na rok liczba urodzeń pozamałżeńskich może stanowić przesłankę do hipotezy o rosnącej tendencji rezygnacji z formalnego małżeństwa na rzecz konkubinatu, który po okresie próby wspólnego zamieszkania albo kończy się 
zawarciem związku, albo rozstaniem, ale nadal dla zdecydowanej większości młodych Polaków podstawę wzajemnego współżycia stanowi formalne małżeństwo.

Wyniki badań empirycznych wskazuja, że instytucja małżeństwa w Polsce nie jest zagrożona, co bez wątpienia należy uznać za zjawisko pozytywne. Z sondaży Centrum Badania Opinii Społecznych wynika, że we wszystkich grupach wieku, poza osobami najmłodszymi, które nie ukończyły jeszcze 20 lat, udział deklarujących wybór małżeństwa bez uprzedniego konkubinatu jest taki sam i wynosi przeciętnie dziewięć na 10 osób ankietowanych. Różnica sprowadza się jedynie do rosnącego odsetka wśród osób młodszych, które poprzedziłyby małżeństwo okresem konkubinatu. Nie bez znaczenia jest fakt, że skłonność do zawarcia małżeństwa jest zbliżona wśród mężczyzn i kobiet.

\section{Małżeństwa}

Natężenie zawierania małżeństw do połowy minionej dekady było stosunkowo niskie. Trzy ostatnie lata przyniosły niewielki wzrost wskaźnika: w 2009 na 10 tys. osób przypadało średnio 78 związków; w rok później proporcja obniżyła się do 70 na 10 tys. Szczegółowe dane prezentuje wykres 7 . 


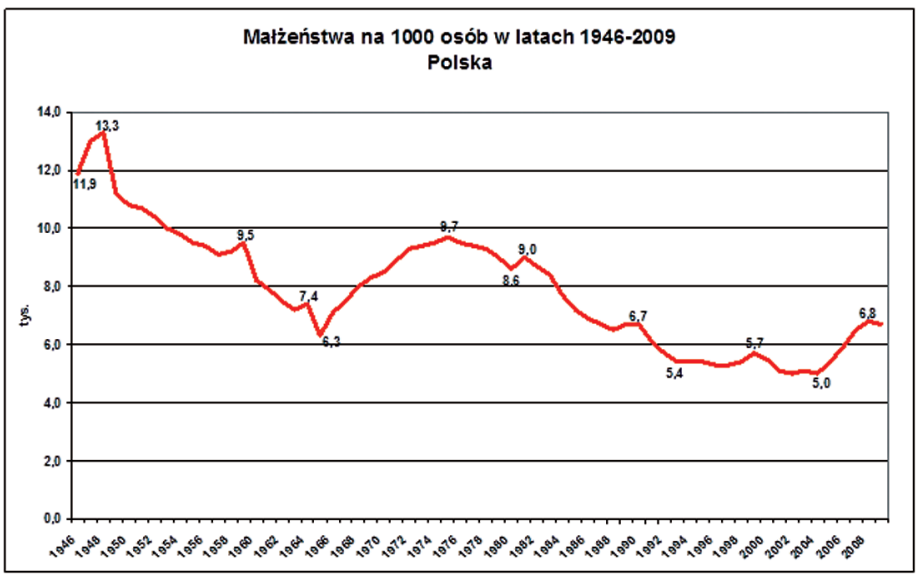

2009 r. - 78 związków na 10 tys. osób; 2010 - 70 związków na 10 tys. osób.

Zwiastunem negatywnych zmian we wzorcu zawierania związków małżeńskich jest obniżający się poziom odsetka osób zawierających pierwsze związki, inaczej mówiąc - małżeństwa zawierane przez panny i kawalerów. O ile w 2005 r. stanowiły one 86,6\%, o tyle w 2011 r. adekwatny odsetek wynosił 84,7\%, co oznacza obniżkę o 2 punkty procentowe. W dwu ostatnich latach na 1000 par małżeńskich przypadało średnio 835 pierwszych małżeństw w 2012 r. i 820 - rok później. Szczegółowe dane o notowanych zmianach prezentuje wykres 9. Wprawdzie trudno jest przewidzieć dalszy scenariusz zmian, ale - mając na uwadze obserwowane zmiany w postawach i zachowaniach matrymonialnych - wysoce prawdopodobny jest spadek udziału małżeństw pierwszych dla obojga małżonków w ogólnej liczbie zawieranych związków. Dokładne informacje o trendach zmian odsetka pierwszych małżeństw prezentuje wykres 8 . W 2013 związki zawierane przez kawalerów i panny stanowiły $83,5 \%$; odsetek kawalerów wynosił 88,3 , a panien $-88,5 \%$. 
Wykres 8.

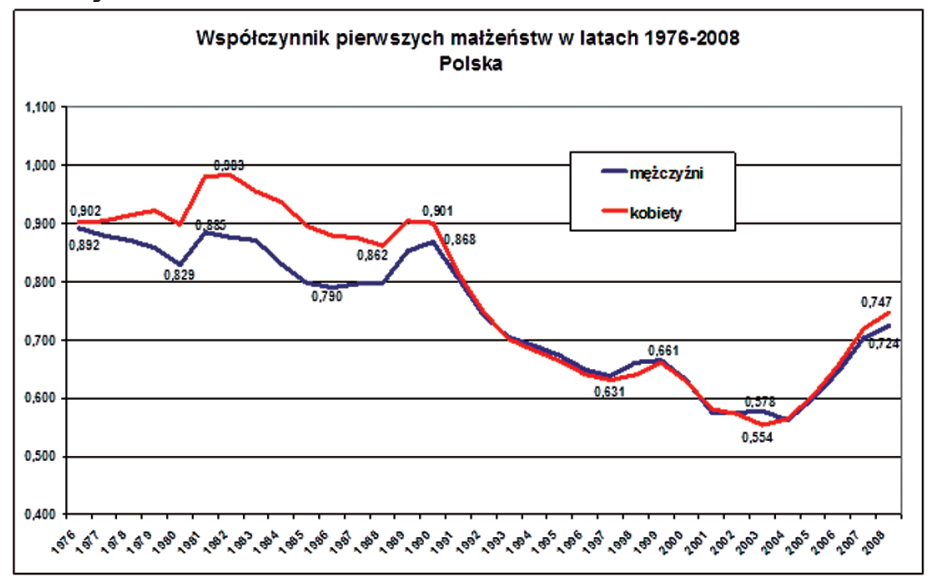

2009 - odsetek 84,8\% ; 2010 - odsetek 84,7\%; 2011 $83,9 \% ; 2012-83,5 \%$.

\section{Rozwody}

Z pozytywnym obrazem zmian liczby małżeństw oraz uznaniem związku małżeńskiego za podstawę tworzenia rodziny idzie $\mathrm{w}$ parze zmienny - a w ostatnich latach - rosnący trend liczby rozwodów. Wyjątek w tym względzie stanowił rok 2010, w którym orzeczono 61,3 tys. rozwodów, tj. o 4 tys. mniej niż rok wcześniej. Wlatach 2000-2010na skutek rozwodu rozpadło sięłącznie 704 tys. związków. Kolejne lata dekady charakteryzowały się dynamicznym wzrostem liczby orzeczeń rozwodowych do osiagnięcia niespotykanego dotąd poziomu 71,9 tys. w 2006 r. W latach 2007 i 2008 liczba orzeczeń była niższa i wynosiła odpowiednio 66,6 tys. oraz 65,5 tys.; w dwu kolejnych latach orzeczono po 61,3 tys. rozwodów. Początek nowej dekady przyniósł znacząco więcej rozwodów w porównaniu z końcem minionego dziesięciolecia. W latach 2011-2012 liczba rozwodów różniła się zaledwie o 0,2 tys., a łącznie orzeczono 129 tys. rozwodów, w 2013 r. rozpadło się 66,1 tys. związków. tj. o 1,7 tys. więcej niż rok wcześniej. Szczegółowe dane 
o liczbie rozwodów w latach 2009-2013 prezentuje poniższe zestawienie.

Rozwody w latach 2009-2013 - liczby absolutne w tys. POLSKA MIASTA WIEŚ ZAGRANICA

$2009 \quad 65,3 \quad 2009 \quad 51,4 \quad 2009 \quad 16,4 \quad 0,490$

$\begin{array}{lllllll}2010 & 61,3 & 2010 & 47,4 & 2010 & 13,4 & 0,484\end{array}$

$\begin{array}{lllllll}2011 & 64,6 & 2011 & 49,2 & 2011 & 14,9 & 0,553\end{array}$

$\begin{array}{lllllll}2012 & 64,4 & 2012 & 48,6 & 2012 & 15,3 & 0,544\end{array}$

$\begin{array}{lllllll}2013 & 66,1 & 2013 & 49,3 & 2013 & 16,1 & 0,66\end{array}$

Z zestawienia liczby rozwodów z populacją nowo zawartych małżeństw wynika, że w okresie od 2005 r., w którym na 1000 nowo zawartych małżeństw przypadło 327 rozwodów, do 2008 r. proporcja ta obniżyła się do 254 na 1000. W 2009 r. orzeczono średnio 261 rozwodów na 1000 nowo zawartych związków, a w rok później-269. W dwu ostatnich latach adekwatna proporcja powiększyła się znacząco do 316 w roku 2012 i 367 - rok później. Szczegółowe dane prezentuje wykres 9.

Wykres 9.

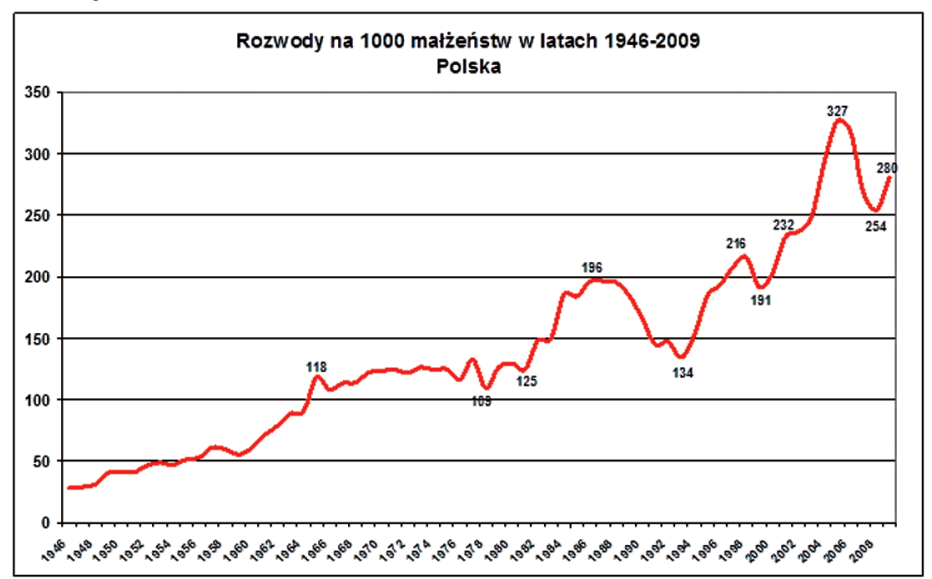

Proporcje rozwodów względem liczby nowo zawieranych związków w latach 2009-2013 przedstawia poniższe zestawienie: 


\begin{tabular}{llllll}
\hline \multicolumn{3}{c}{$\begin{array}{l}\text { Rozwody w latach } \\
\text { 2009-2013 na }\end{array}$} \\
małżeństw \\
POLSKA & \multicolumn{3}{l}{ MIASTA } & WIEŚ \\
2009 & 261 & 2009 & 337 & 2009 & 137 \\
2010 & 269 & 2010 & 345 & 2010 & 147 \\
2011 & 313 & 2011 & 401 & 2011 & 177 \\
2012 & 316 & 2012 & 407 & 2012 & 182 \\
2013 & 367 & 2013 & 467 & 2013 & 216
\end{tabular}

\section{Uwarunkowania zmian decyzji matrymonialnych i prokreacyjnych}

Wśród wielu różnorodnych czynników wpływających na zachowania matrymonialne i prokreacyjne współczesnych społeczeństw jedną z najczęściej poruszanych kwestii związanych z decyzjami prokreacyjnymi są trudności w godzeniu ról zawodowych z rodzinnymi. Grupą szczególnie zainteresowaną zatrudnieniem nietypowym, częścią etatu, bądź też elastycznym czasem pracy, są kobiety już posiadające dzieci bądź też planujące je mieć w najbliższej przyszłości. Tymczasem te formy zatrudnienia w naszym kraju są dla wielu kobiet niedostępne z różnych powodów, w szczególności jednak - ze względu na ich ograniczoną podaż. Istotną barierą na drodze ku zwiększeniu aktywności zawodowej Polek jest przede wszystkim niski poziom dostępu do usług opiekuńczych: liczba miejsc w żłobkach i przedszkolach, które są w stanie przyjąć chętnych, jest zbyt mała, zatem przyjęcie wszystkich kandydatów na przedszkolaków nie jest możliwe. Ponad to wysokie opłaty za pobyt dziecka w przedszkolu są dla niektórych rodziców barierą nie do pokonania ze względu na ich niskie dochody; podobnie koszty opieki nad dzieckiem w przedszkolach prywatnych są zbyt wysokie, by móc z nich korzystać. Polska notuje jeden z najniższych wskaźników instytucjonalnej opieki nad najmłodszymi dziećmi w Europie. W roku 2010/2011 na 1000 dzieci w wieku przedszkolnym (3-6 lat) przypadało średnio 538 dzieci objętych opieką przedszkolną. Rok wcześniej proporcja ta wynosiła 673 na 1000. Wskaźniki 
aktywności zawodowej kobiet w Polsce osiągają najwyższy poziom wśród kobiet w wieku 30-50 lat; najmniej zaangażowane w pracę zawodową są młode Polki w wieku 20-24 lata. Te w większości jeszcze się ucza, a w 2010 r. 80,1 tys. $z$ nich zostało matkami, co stanowiło 19,3\% ogółu kobiet rodzących; w tym samym roku odsetek matek rodzących dzieci w wieku 25-29 lat wynosił 36,9\%. Wobec faktu najczęstszego podejmowania decyzji matrymonialnych przez kobiety w wieku 20-29 lata (w 2010 r. stanowiły one $74,2 \%$ ogółu kobiet zawierających małżeństwo) oraz najwyższego udziału kobiet rodzących dzieci w wieku 25-34 lata (w tym samym roku stanowiły one 64,4\% ogółu kobiet rodzących dzieci, przy czym 37,0\% kobiet było w wieku 25-29 lat, a 27,4\% - w wieku 30-34 lata) brak miejsc w przedszkolach istotnie ogranicza możliwość godzenia pracy młodych matek z opieką nad dzieckiem.

Mniejszy wymiar czasu pracy lub też nietypowa forma zatrudnienia byłyby dla żon i matek idealnym sposobem rozwiązania konfliktu, jaki rodzi się między karierą zawodową a rolą spełnianą przez nie w rodzinie. Kraje Europy Zachodniej mogą pochwalić się wzrostem zatrudnienia swoich mieszkanek, ponieważ kobiety opiekujące się dziećmi, zamiast całkowicie rezygnować z pracy, jedynie ograniczają wymiar czasu, jaki opiece poświęcają. W Polsce taka możliwość jest bardzo ograniczona. Toteż matki albo całkowicie porzucają pracę na czas zajmowania się potomstwem, albo pracują na pełny etat, podczas gdy dzieckiem zajmuje się kto inny. Wyniki badań Diagnoza Społeczna 2009 informują, że przeciętnie w przypadku 49 na 100 ankietowanych kobiet, posiadających dzieci do lat 3, dominującym modelem jest rodzina, w której mężczyzna pracował w pełnym wymiarze godzin, a kobieta przerywała pracę na pewien okres. Proporcja rodzin z dziećmi do lat 3, w których mężczyzna pracował w pełnym wymiarze godzin, a kobieta - na część etatu, był niemal dwa i pół razy niższy (wynosił 20,2\%). Jego poziom był również niższy od udziału rodzin, w których kobieta rezygnowała z pracy w ogóle $(24,2 \%)$. Powyższe 
proporcje ulegają całkowitemu odwróceniu w przypadku rodzin z dziećmi w wieku przedszkolnym (3-6 lat): w grupie tej rodziny z ojcem pracującym na pełny etat i matką przerywającą pracę stanowiły $24,6 \%$, przeciętnie w 47 na 100 rodzin kobieta pracowała na część etatu, a w 11,5\% matka rezygnowała z pracy w ogóle. Według wyników wspomnianej Diagnozy Społecznej 2009:

- prace w niepetnym wymiarze godzin jako najlepsze rozwiązanie pozwalające na godzenie pracy zawodowej z wychowaniem dzieci wskazało 8\% ankietowanych kobiet;

- 21,5\% osób wskazało na dłuższy urlop macierzyński,

- 14,0\% - na elastyczny czas pracy,

- 11,7\% - na większe możliwości opieki nad dziećmi do lat 7 poza domem,

- 10,9\% - na wyższe zasiłki wychowawcze na dzieci,

- 10,4\% - na dtuższy płatny urlop wychowawczy.

Na podkreślenie zasługuje fakt, że 17,8\% osób ankietowanych swój powrót do pracy warunkowało uzyskaniem możliwości pracy na część etatu, a w poszukiwaniu optymalnych rozwiązań problemu godzenia pracy zawodowej z opieką nad dziećmi za podstawowy warunek aktywizacji zawodowej młodych kobiet uznaje się powszechny system instytucjonalnej opieki nad dziećmi do lat 5 . W grupie czynników warunkujących stosunkowo niski poziom analizowanego odsetka w relacji do innych krajów można wskazać następujące:

- upowszechniony model opieki nad najmłodszymi dziećmi - jeśli nie matki lub babci - to innych osób z najbliższej rodziny,

- nieodptatna opieka krewnych spoza gospodarstwa domowego,

- opieka odpłatnej niani.

W świadomości społecznej nieprzerwanie istnieje przekonanie, że praca zawodowa ogranicza możliwości posiadania i wychowywania dzieci. Wpływa to bezwzględnie na decyzje części kobiet o rezygnacji z pracy, gdy w rodzinie pojawia się potomstwo, podczas gdy przykłady wielu innych krajów wskazuja, że ambicje zawodowe mogą iść 
w parze z ambicjami macierzyńskimi. Z drugiej strony, w warunkach utrudniających łączenie pracy zawodowej z opieką nad dzieckiem pojawia się ryzyko skłonności do odraczania decyzji prokreacyjnych, a ostatecznym efektem takiego scenariusza jest zwykle niższa dzietność.

Niski poziom dzietności wiąże się z odraczaniem decyzji prokreacyjnych również ze względu na: wydłużanie czasu nauki, trudności ze znalezieniem stałego partnera i założeniem własnego gospodarstwa domowego, sytuację ekonomiczną i niepewność zatrudnienia, lęk przed godzeniem wyzwań konkurencyjnego rynku pracy i roli opiekuńczo-wychowawczej, kojarzonej z rosnącą odpowiedzialnością za podejmowanie każdego z tych zadań. Dodatkowo, coraz częściej dziecko jest uznawane: za wartość o charakterze konsumpcyjnym, jako czynnik zaspokajający potrzeby rodzicielskie, przynoszące radość i satysfakcję, a nie jako wartość sama w sobie.

Dzisiaj o liczbie dzieci z wyboru i ich miejscu w rodzinie decyduje coraz częściej swoisty „rachunek ekonomiczny", podobny do stosowanego przy dokonywaniu decyzji związanych z nabywaniem dóbr luksusowych. Podejmowane decyzje stanowią wypadkową kalkulacji kosztów i korzyści w przypadku posiadania dzieci, a także konkurencyjności innych dóbr trwałego użytku. Istotne znaczenie posiada również dominująca w niektórych środowiskach orientacja indywidualistyczna. Ujmuje ona plan życiowy młodych ludzi niemal wyłącznie w wymiernych kategoriach osobistego sukcesu rozumianego jako zwiększenie i urealnienie dostępu do dóbr konsumpcyjnych. Zanika natomiast poczucie współodpowiedzialności za szersze społeczności: rodzina coraz rzadziej bywa traktowana jako odpowiedzialna służba. Stąd występujące problemy ludnościowe kraju nie stanowią przesłanek dla podejmowanych rozstrzygnięć prokreacyjnych.

Do niedawna wyniki badań empirycznych informowały, że zdecydowana większość młodych ludzi uznaje rodzinę i dziecko na wartości nadrzędne i deklaruje pragnienie stania się rodzicami. Najnowsze sondaże wska- 
zują że wprawdzie instytucja małżeństwa jest stawiana przez dziewczęta na pierwszym miejscu wśród celów życiowych, ale w opiniach pojawia się dylemat, który do niedawna nie istniał, a mianowicie dopuszczanie związków nieformalnych. Dla wielu młodych mężczyzn najważniejsze są wykształcenie, zawód, kariera, a dopiero po nich - małżeństwo. Młodzi mężczyźni również częściej niż kobiety dopuszczają związki pozamałżeńskie. Zaprezentowane postawy znajdują epilog w podobnych zachowaniach, prowadzących do niepokojących przemian wzorca tworzenia rodziny i sposobu jej funkcjonowania.

Trudno uznać notowane przeobrażenia za pozytywne, czego wyrazem jest powszechna świadomość ich negatywnych konsekwencji dla przyszłego stanu i struktury ludności. Przyczyn dostrzeganych przeobrażeń większość społeczeństwa dopatruje się głównie w przemianach społeczno-ekonomicznych, takich jak bezrobocie, wysokie ceny mieszkań, wzrost czynnika materialnego w uzyskaniu odpowiedniej pozycji społecznej. Z drugiej strony, brak wystarczającego, społecznego wsparcia dla rodzin nie zachęca młodych do ich zakładania i rozwoju, mimo że w hierarchii wartości deklarowanych udane życie małżeńskie i rodzinne stawiane jest na jednym z czołowych miejsc. Nie tylko w naszym kraju istnieje ogromne zapotrzebowanie na społeczno-ekonomiczne działania wspierające rodziny w pełnieniu przez nie rozlicznych zadań, w tym przede wszystkim funkcji opiekuńczo-wychowawczej i ekonomicznej. Skuteczna polityka prorodzinna jest pożądana w całej Europie, a najbardziej - w jej środkowo-wschodniej części. Tymczasem coraz rzadziej małżeństwo i rodzina przestają być podmiotem społecznego postrzegania, a coraz częściej są w społeczeństwie traktowane jako sprawa prywatna. Negatywne konsekwencje zaniedbań rodziny wskazują na pilną potrzebę tworzenia zasad spójnego i efektywnego działania na rzecz tej małej wspólnoty. 


\section{Wnioski końcowe}

Spostrzeżenia i wnioski zaprezentowane w powyższym opracowaniu pomagają odpowiedzieć na pytanie: Dlaczego w Polsce rodzi się tak mało dzieci ? Uogólniając je, przyczyny niskiej dzietności należy upatrywać głównie w czynnikach zewnętrznych. Wśród nich do najczęściej wskazywanych należy czynnik ekonomiczny oraz konflikt ról zawodowych i opiekuńczo-wychowawczych. Warto zastanowić się, czy wymieniane przyczyny rzeczywiście powinny górować nad decyzjami rodzicielskimi i perspektywą radości $\mathrm{z}$ obecności dziecka w naszych rodzinach? A może to egoizm lub ucieczka przed odpowiedzialnością za opiekę i wychowanie dziecka stanowią bariery przy podejmowaniu decyzji o pierwszym czy kolejnym dziecku? Mając na uwadze wspomniane różne czynniki, determinujące ograniczanie planów rodzicielskich, w kontekście uwarunkowań zewnętrznych i wewnętrznych kształtujących dzietność rodziny, można przedstawić możliwe scenariusze poziomu dzietności rodzin w Polsce w bliższej i bardzo odległej perspektywie. Wybrane czynniki zewnętrzne i wewnętrzne mogą oddziaływać na dzietność rodziny w następujących kierunkach:

Warunki materialne. Powszechne dążenie do poprawy warunków materialnych i ich rosnąca rola w osiąganiu przez rodzinę wyższej pozycji ekonomicznej i społecznej oraz w zapewnieniu dzieciom i młodzieży możliwości inwestowania w ich kształcenie i rozwój stanowią poważne zagrożenie dla wyższej dzietności rodzin. Według danych zawartych $\mathrm{w}$ raporcie OBOP-u wielu rodziców nie stać na opłaty za pobyt dziecka w przedszkolu, toteż dziećmi zwykle zajmują się dziadkowie, a zdecydowanie rzadziej - przedszkole lub żłobek. Znaczącej grupy matek nie stać na opłacenie należności za pobyt dziecka w przedszkolu, średnio co dziesiąta matka - rezygnuje z pracy.

Praca zawodowa kobiet. Kobiety aktywne zawodowo zwykle decydują się na mniejszą liczbę dzieci z dwu względów. Po pierwsze, decyzja o urodzeniu dziecka 
może spowodować utratę pracy, co przy istniejącym bezrobociu stanowi poważne zagrożenie, lub kolidować z możliwością zdobywania kolejnych szczebli w karierze zawodowej. Dzieje się tak dlatego, że mimo ochrony prawnej, w rzeczywistości kobiety przegrywają z mężczyznami w wyborach na pracownika. Nierzadko młoda matka musi po zakończeniu urlopu wychowawczego szukać nowej pracy. Sytuacja ta jest powodowana m.in. również racją relatywnie wysokiego współczynnika kobiet bezrobotnych, nie tylko najmłodszych w wieku od 18 do 30 lat, ale także w wieku średnim. $Z$ kolei, matki licznych rodzin są $\mathrm{w}$ mniejszym stopniu aktywne zawodowo $\mathrm{z}$ uwagi na trudności w godzeniu obowiązków rodzinnych z zawodowymi, co prowadzi do pogorszenia ich warunków bytowych. Te względy również przemawiają przeciwko posiadaniu licznych rodzin.

Wykształcenie. Coraz bardziej pożądane i osiagane wykształcenie wyższe idzie w parze $\mathrm{z}$ małodzietnościa, niższemu częściej towarzyszy średnio i wielodzietność. Powszechne dążenie do podwyższania poziomu edukacji powoduje odkładanie decyzji o zawarciu małżeństwa i o rodzicielstwie przez najmłodszą generację potencjalnych matek i ojców. Późniejsze urodzenie pierwszego dziecka owocuje zwykle ograniczaniem dzietności rodziny.

Opinia społeczna. Liczna rodzina nie przestaje być poddawana negatywnej presji otoczenia; postrzegana nierzadko jako przejaw patologii oraz braku odpowiedzialności za właściwy rozwój dzieci, przy tym doświadczająca bardziej niż inne rodziny trudności w realizacji spotęgowanych funkcji, ma bardzo ograniczone możliwości przetrwania we współczesnym społeczeństwie. Dla wielu rodzin obawa przez brakiem akceptacji wielodzietności oraz trudnymi warunkami bytu będzie stanowić przeszkodę w realizacji bogatszych planów rodzicielskich.

Polityka rodzinna. Działalność państwa w tym zakresie nie ma w Polsce najlepszych notowań. Niezależnie od opcji politycznej, bywa najczęściej mylona z opieką socjalną i ma charakter doraźnych zrywów; ich przykładem 
może być „,becikowe”, ograniczony dostęp do przedszkoli dzieci z rodzin z obojgiem rodziców (nawet przy niższym poziomie ich zamożności) w stosunku do dzieci z małżeństw rozwiedzionych, które nierzadko decydowały się na fikcyjny rozwód tylko ze względu na większe szanse umieszczenia dziecka w przedszkolu. Działania dalekie od obiecywanego i oczekiwanego efektu wzmacniające rodzinę $\mathrm{w}$ pełnieniu przez nią określonych funkcji, wynikające po części z uznania rodziny za sprawę prywatna, oraz przyznawanie w polityce społeczno-gospodarczej priorytetu rozwojowi gospodarczemu, ogranicza możliwość wspierania rodzin poprzez odpowiedni system zasiłków i finansowego wspierania w pokrywaniu kosztów opieki nad dziećmi i ich edukacji. Skazuje to często rodziny potrzebujące permanentnej pomocy na upokorzenia związane z życiem na poziomie minimum oraz koniecznością korzystania z pomocy społecznej.

Postawy konsumpcyjne. Dążenie do nieustannego podwyższania standardu ekonomicznego w celu dorównywania innym, którzy się lepiej maja, stoi w sprzeczności z większą liczbą dzieci w rodzinie. Coraz częściej powtarzane hasła konieczności inwestowania w kapitał ludzki, przez który należy rozumieć przede wszystkim odpowiedni poziom edukacji oraz zasoby umiejętności młodego pokolenia, będą wstrzymywać większość rodziców przed podejmowaniem decyzji o urodzeniu więcej niż jednego dziecka.

Zmiany w systemie norm i wartości. Mimo iż w świetle deklarowanych postaw i zachowań młodego pokolenia życie małżeńskie i rodzinne jest stawiane na czołowym miejscu, w zachowaniach zaczyna ono ustępować miejsca innym wartościom. Postawa być ustępuje miejsca postawie mieć, a dziecko coraz częściej jest traktowane w sensie przedmiotowym jako kolejny zasób po dobrej pracy, własnym, należycie wyposażonym mieszkaniu, samochodzie wysokiej marki itp.

Obniżanie aktywności religijnej w społeczeństwie. Zgodnie z zasadami nauki Kościoła Katolickiego dziecko 
jest darem Bożym i wyrazem Bożego błogosławieństwa, stąd wielodzietność często kojarzy się z większym zaangażowaniem w sprawy wiary. Osłabianie religijności prowadzi do osłabiania tego motywu jako determinanty dzietności. Pełna akceptacja katolickich norm moralnych sprzyja modelowi rodziny wielodzietnej, moralny relatywizm osłabia motywację do posiadania licznego potomstwa. Ponieważ relatywizm zyskuje na znaczeniu, można obawiać się o losy wyższej dzietności, przynajmniej w tej grupie rodzin, które bardziej deklarują niż praktykują katolicyzm.

Świadome rodzicielstwo.Znajomośći stosowanie ,skutecznych" metod regulacji poczęć prowadzi do ograniczania liczby poczęć przypadkowych, co w znaczącej mierze przesądza o małodzietności. Nie sposób nie zauważyć, że przygotowanie młodego pokolenia do odpowiedzialnego rodzicielstwa i życia w rodzinie, zaprogramowane w obowiązującym systemie edukacji, będzie sprzyjać ograniczaniu dzietności niezamierzonej na rzecz dzietności z wyboru, co niewątpliwie można byłoby uznać za czynnik pozytywny, ale tylko wówczas, gdy stosowanie metod planowania rodziny nie jest skierowane przeciw życiu poczętego dziecka.

Niezależnie od istniejących barier w skutecznym działaniu na rzecz rodziny wyzwaniem dla każdego z nas winna być głęboka troska o małżeństwo, rodzinę i dzieci i to nie tylko wtedy, gdy pojawia się ryzyko niewydolności w zapewnieniu im godnego życia i prawidłowego rozwoju, ale od dzieciństwa po młodość, dorastanie, osiągnięcie dojrzałości aż do jesieni i zimy życia. 


\section{Część I}

Współczesna sytuacja demograficzna w Polsce

7. Sytuacja demograficzna Polski na tle innych państw

Wykres 1. Urodzenia na 1000 ludności w krajach europejskich w 2012 r.

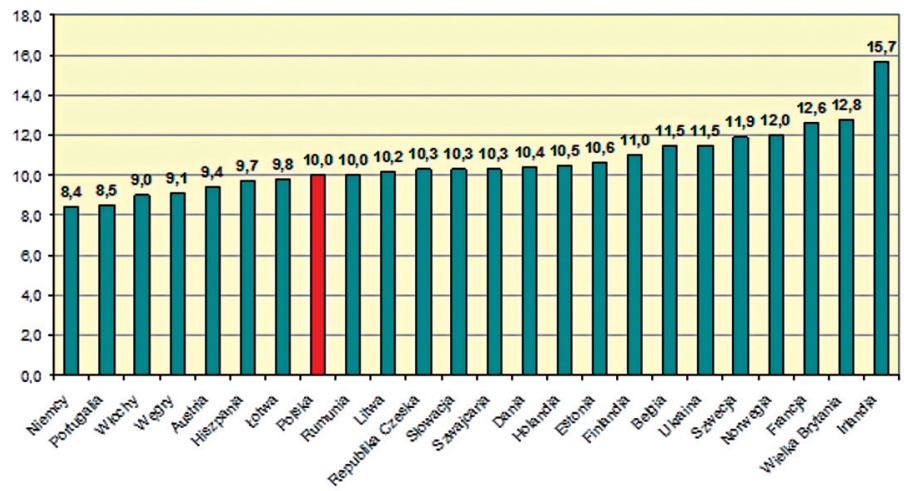

Wykres 2. Zgony na 1000 ludności w krajach europejskich w 2012 r.

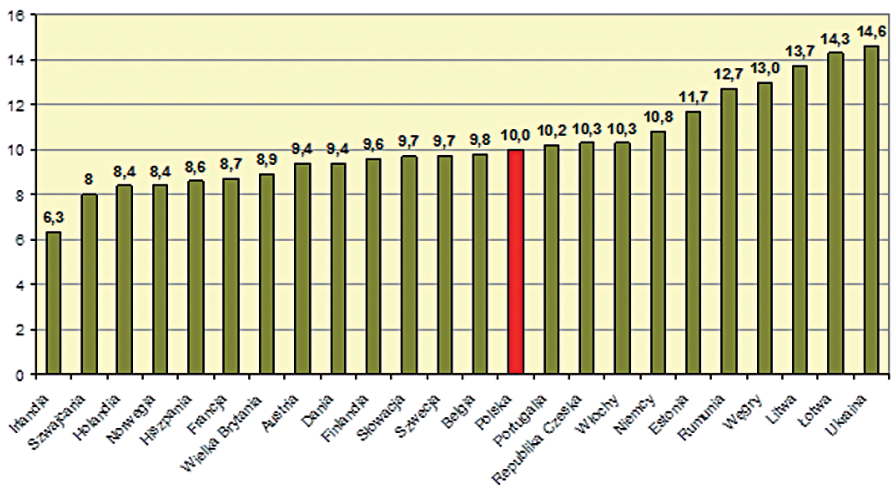


Wykres 3. Przyrost naturalny na 1000 ludności w krajach europejskich w 2012 r.

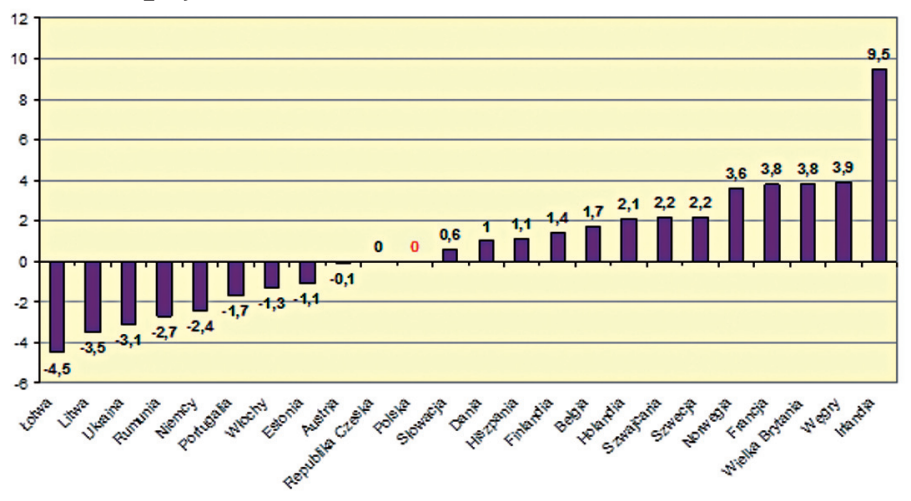

Wykres 4. Współczynnik małżeństw na 1000 ludności w krajach europejskich w 2012 r.

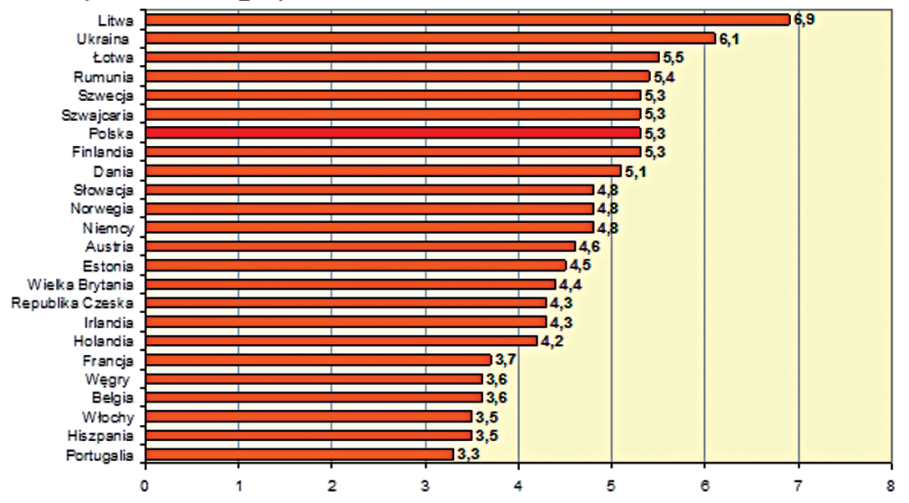




\section{Część I}

Współczesna sytuacja demograficzna w Polsce

Wykres 5. Współczynnik rozwodów na 1000 ludności w krajach europejskich w 2012 r.

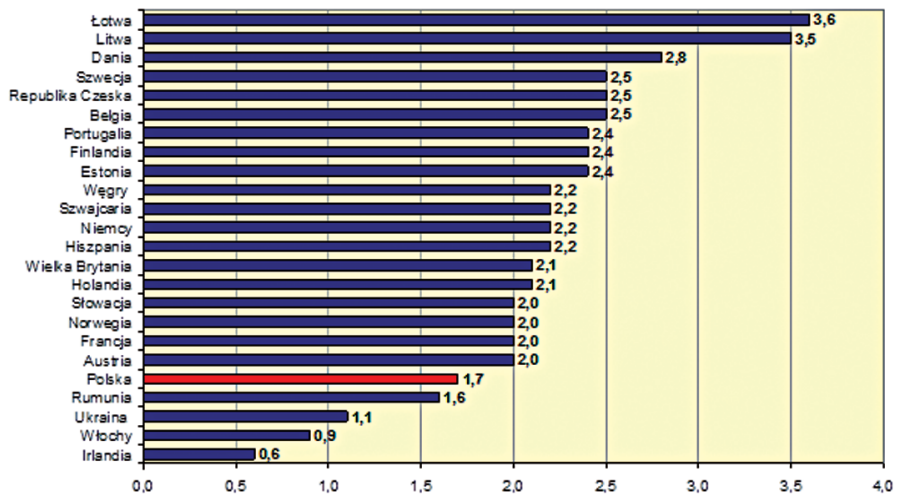

Wykres 6. Urodzenia pozamałżeńskie. Od setek ogółu urodzonych dzieci w krajach europejskich w 2012 r.

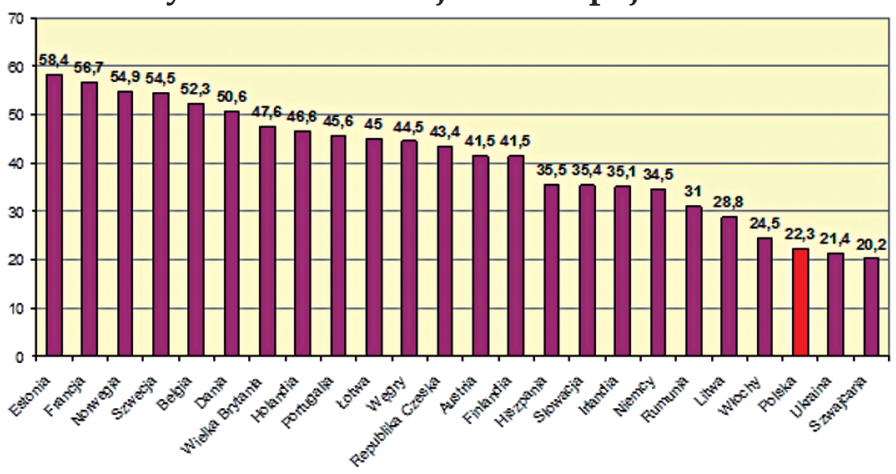




\section{Część I}

Współczesna sytuacja demograficzna w Polsce

Wykres 7. Współczynnik dzietności w krajach europejskich w 2012 r.

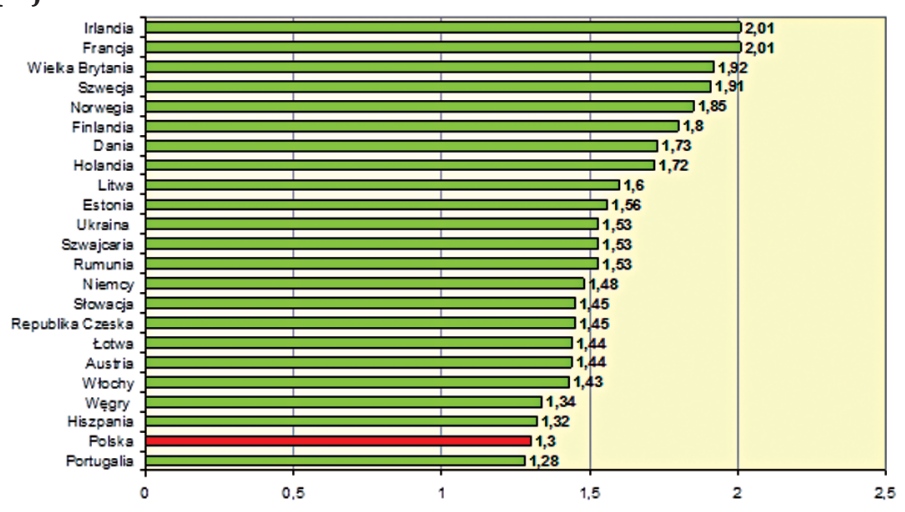





\section{Ks. Piotr Mazurkiewicz}

Instytut Politologii UKSW

\section{Kościót wobec wyzwań demograficznych}

\section{Wstęp}

Czy Kościół powinien zajmować się demografią? Nawet pobieżne przejrzenie podstawowych dokumentów z zakresu nauczania społecznego Kościoła pokazuje, że poświęca on temu zagadnieniu stosunkowo dużo miejsca ${ }^{1}$. Pojawia się ono w dwóch kontekstach. Z jednej strony, w związku z prawami i obowiązkami rodziców, z drugiej zaś, w kontekście odpowiedzialności za wspólnotę narodową lub - częściej - globalną. Ten drugi wątek wiąże się z analizą założeń filozoficznych oraz praktycznych postulatów politycznych zgłaszanych przez międzynarodowe organizacje, rządy niektórych państw czy też organizacje pozarządowe. $W$ tym drugim zakresie papieże podejmują dyskusję z teoriami neo-maltuzjańskimi zapowiadającymi „demograficzną eksplozję", która sprokuruje globalny kryzys żywnościowy ${ }^{2}$. W ostatnich czasach powraca często pytanie - pisze Jan XXIII - w jaki sposób można by uzgodnić działalność gospodarcza $i$ dobre warunki bytowe z poważnym wzrostem liczby ludności, tak odnośnie całego świata, jak i narodów cierpiacych niedostatek. Jeśli idzie o cały świat, to niektórzy na podstawie obliczeń i przewidywań statystycznych uwa-

1 W tekście używam słowa „Kościół” na ogół jako synonimu Urzędu Nauczycielskiego Kościoła.

2 Jak podkreśla Gérard-Francois Dumont, wyrażenia takie jak „,bomba P” (Paul Ehrlich) czy „eksplozja demograficzna” (Klub Rzymski) zostały wymyślone jedynie po to, aby straszyć ludzi. Na gruncie demografii nie mają one żadnej wartości eksplikatywnej. Por. G.-F. Dumont, Démographie, transition démographique et politiques démographiques, w: Conseil Pontifical pour la Famille, Lexique des termes ambigus et controversés sur la famille, la vie et les questions éthiques, Paryż 2005, s. 235-237. 
żaja, że liczba ludności w ciagu kilkudziesięciu lat gwałtownie wzrośnie, podczas gdy rozwój gospodarczy będzie postępowat o wiele wolniej. Sa tacy, którzy wyprowadzaja z tego wniosek, że jeśli nie ustali się jakichś norm przyrostu ludności, to w niedługim czasie ulegnie powiększeniu dysproporcja między liczba ludności a ilościa niezbędnych środków utrzymania ${ }^{3}$. Przypomnijmy, że podstawowa teza Thomasa Roberta Malthusa głosiła, że liczba ludności świata wzrasta w porządku geometrycznym, podczas gdy produkcja żywności w porządku arytmetycznym. Aby przywrócić równowagę należy zatem ograniczyć przyrost ludności, na przykład, opóźniając moment założenia rodziny, oraz przywrócić naturze możliwość eliminacji osób „niepotrzebnych”4 . Ta druga teza, za sprawą takich ludzi jak Francis Galton czy Margaret Sanger, powiązała na stałe maltuzjanizm z eugeniką ${ }^{5}$.

\section{1. „Naukowo" uzasadniony spisek przeciwko życiu}

Już w Mater et magistra wyrażona jest poważna wątpliwość odnośnie do naukowej poprawności danych, na które powołuje się teoria neo-maltuzjańska. Prawdę rzekłszy, biorąc pod uwage stosunek liczby ludności do zasobów w skali światowej, ani obecnie, ani na niedaleka przyszłość nie można na tej podstawie przewidywać poważnych trudności. Wysuwane bowiem w tej sprawie tezy sa tak niepewne i sprzeczne, że nie można z nich wyprowadzić żadnych niewątpliwych wniosków ${ }^{6}$. Hipotezy te nie uwzględniają w wystarczającym stopniu ani niewyczerpanej prawie płodności przyrody, ani kreatywności ludzkiego umysłu, wynajdującego wciąż nowe, bardziej efektywne sposoby produkcji żywności. W efekcie tak redukcjonistycznego podejścia, znaleźli się

Jan XXIII, Mater et magistra, 186-187.

Por. T. R. Malthus, Prawo ludności, Warszawa 2007, s. 69-76,87.

Por. M. Schooyans, Démographie, contrôle de naissances et crash démographique, w: Conseil Pontifical pour la Famille, Lexique des termes ambigus et controversés sur la famille, la vie et les questions éthiques, dz. cyt., s. 207-209.

6 Jan XXIII, Mater et magistra, 189. 


\section{Część I}

Współczesna sytuacja demograficzna w Polsce

tacy, którzy (...) sadza, że należy unikać poczęć i urodzeń, względnie liczbę ich wszelkimi sposobami ograniczaćt. Jan XXIII zwraca uwagę, że podstawą neo-maltuzjańskiej polityki jest wyraźnie materialistyczna wizja świata i życia, która powoduje, że w stosunku do człowieka stosuje się środki i metody, które są wprawdzie dozwolone w przekazywaniu życia roślin i zwierząt, ale zastosowane do człowieka okrywają hańba (...) rodzaj ludzki $i^{8}$ W późniejszych tekstach, Jana Pawła II, wyraźnie podkreśla się uproszczony charakter neo-maltuzjańskich analiz odnośnie do zachodzących w świecie przemian demograficznych. Przebiegaja one odmiennie w różnych czéściach świata: w krajach bogatych i rozwiniętych obserwujemy niepokojacy spadek, czasem bardzo gwałtowny, liczby urodzin; kraje ubogie natomiast maja na ogót wysoki wskaźnik przyrostu ludności, co stwarza trudne do rozwiązania problemy w kontekście powolniejszego rozwoju gospodarczego i społecznego czy wręcz głębokiego zacofania9.

Wydaje się, że dopiero w świetle tej uwagi o demograficznym „podziale świata”, daje się zrozumieć istotę międzynarodowych kampanii przeciw przyrostowi naturalnemu, w ramach których bogaci płacą za ograniczenie przyrostu ludności w krajach biednych ${ }^{10}$. Często te kam-

Tamże, 188 .

Tamże, 192, 194.

Jan Paweł II, Evangelium vitae, 16. Por. Jan Paweł II, Sollicitudo rei socialis, 25. W przypadku Europy, odnotowującej ujemny przyrost demograficzny, raczej mówi się dzisiaj o „zimie demograficznej” czy wręcz o „implozji Europy”. Por. G.-F. Dumont, Démographie: son implosion en Europe, dz. cyt., s. 221-234.

10 Kluczowe znaczenie dla zrozumienia tego procesu ma opracowany w roku 1974 Raport Kissingera, w którym przyrost ludności w krajach słabo rozwiniętych (LDC) przedstawia się jako poważne zagrożenie dla dominującej w polityce międzynarodowej pozycji Stanów Zjednoczonych oraz dla interesów gospodarczych USA. Ograniczenie populacji w krajach $L D C$ wymaga zaangażowania ONZ, wybranych międzynarodowych organizacji pozarządowych oraz spowodowania, że same te kraje zaangażują się w ograniczanie liczebności własnej populacji. Z Raportu wynika, że od samego momentu ogłoszenia „alarmu demograficznego" jego autorzy mieli pełną jasność, że jest to fałszywy alarm (National Security Council, Washington D.C. 20506, Implications of Worldwide Population Growth for U.S. Security and Overseas Interests (The 


\section{Część I}

Współczesna sytuacja demograficzna w Polsce

panie sa wymuszane i finansowane przez kapitaty pochodzace z zagranicy, niekiedy zaś od nich bywaja wręcz uzależnione pomoce i opieka ekonomiczno-finansowa. W każdym razie przejawia sie w tym zupetny brak poszanowania wolnej decyzji zainteresowanych osób, mężczyzn i kobiet, poddanych nierzadko bezwzględnym naciskom, również ekonomicznym, majacym podporzadkować ich tej nowej formie przemocy. Właśnie ludy najuboższe doznaja takich krzywd: doprowadza to niekiedy do pojawiania się tendencji do rasizmu lub sprzyja wprowadzaniu pewnych, również rasistowskich form eugenizmu ${ }^{11}$. W Evangelium vitae Jan Paweł II wyjaśnia, że wobec problemu przeludnienia krajów ubogich społeczność międzynarodowa nie podejmuje odpowiednich działań na skalę globalna, a realizuje jedynie różne formy polityki antynatalistycznej. Oni (możni tego świata) sa przerażeni obecnym tempem przyrostu ludności i obawiaja się, że narody najbardziej płodne i najuboższe stanowia zagrożenie dla dobrobytu i bezpieczeństwa ich krajów. W konsekwencji, zamiast podjać próbę rozwiąania tych poważnych problemów w duchu poszanowania godności osób i rodzin oraz nienaruszalnego prawa każdego człowieka do życia, wola propagować albo narzucać wszelkimi środkami na skale masowa polityke planowania urodzin. Nawet wówczas, gdy proponuja pomoc gospodarcza, uzależniaja ja wbrew sprawiedliwości od akceptacji polityki antynatalistycznej ${ }^{12}$.

Kissinger Report), <http://pdf.usaid.gov/pdfdocs/PCAAB500.pdf>; Life Issues, Kissinger Report 2004. A Retrospective on NSSM-200, <http://www. lifeissues.net/writers/clo/KissingerReport2004.pdf)>. Inną interesującą opinią z tego zakresu jest pogląd wyrażony przez Jacques-Yves Cousteau w wywiadzie opublikowanym w "The UNESCO Currier": Our society is geared to increasingly useless consumption. It's a vicious circle which I compare to a cancer. What should we do to eliminate suffering and disease? It's a wonderful idea but perhaps not altogether a beneficial one in the long run. If we try to implement it we may jeopardize the future of our species. It's terrible to have to say this. World population must be stabilized and to do that we must eliminate 350,000 people per day. This is so horrible to contemplate that we shouldn't even say it. But the general situation in which we are involved is lamentable. J.-Y. Cousteau, Interview, "The UNESCO Currier", November 1991, s. 13, <http://unesdoc.unesco.org/images/0009/000902/090256eo. pdf)>.

11 Jan Paweł II, Sollicitudo rei socialis, 25.

12 Jan Paweł II, Evangelium vitae, 16. 


\section{Część I}

Współczesna sytuacja demograficzna w Polsce

Współcześnie, obok „tradycyjnych” zagrożeń dla życia ludzkiego, jakie niosą na przykład żywioły przyrody albo „Kainowie”, którzy zabijają "Ablów”, pojawiają się także zagrożenia zaprogramowane w sposób naukowy $i$ systematyczny. Wiek XX zapisze się jako epoka masowych ataków na życie, jako nie kończąca się seria wojen i nieustanna masakra niewinnych istot ludzkich. Fałszywi prorocy i fatszywi nauczyciele odnieśli w tym stuleciu największe sukcesy. Niezależnie od intencji, które bywaja różne i moga się nawet wydawać przekonujace czy wręcz powoływać się na zasadę solidarności, stoimy tu w rzeczywistości wobec obiektywnego spisku przeciw życiu, w który zamieszane sa także insty tucje międzynarodowe, zajmujace sie propagowaniem i planowaniem prawdziwych kampanii na rzecz upowszechnienia antykoncepcji, sterylizacji $i$ aborcji. Nie można (...) zaprzeczyć, że również środki społecznego przekazu biora często udział w tym spisku, utwierdzajac w opinii publicznej owa kulture, która uważa stosowanie antykoncepcji, sterylizacji, aborcji, a nawet eutanazji za przejaw postepu $i z d o-$ bycz wolności, natomiast postawę bezwarunkowej obrony życia ukazuja jako wroga wolności i postępowi ${ }^{13}$. Zdaniem Jana Pawła II, mamy obecnie do czynienia z brutalną walką ekonomiczną bogatych przeciwko ubogim, podszytą rasizmem i pseudonauką (eugeniką), którą propaguje się w świecie pod pozorem pomocy humanitarnej ${ }^{14}$. Benedykt XVI zwraca uwagę, że obok organizacji międzynarodowych i rządów niektórych państw, w kampanie tę angażują się także liczne organizacje pozarządowe: Następnie niektóre organizacje pozarzadowe angażuja się czynnie w propagowanie aborcji, promujac niekiedy w krajach ubogich stosowanie praktyki sterylizacji, także w wypadku kobiet nieświadomych tego. Istnieje ponadto uzasadnione podejrzenie, że czasami pomoc na

Tamże, 17.

14 Począwszy od Konferencji w Bukareszcie (1974), integralną częścią polityki demograficznej jest teza o konieczności ochrony „dziedzictwa genetycznego ludzkości”, które mogłoby ulec degradacji za sprawą niekontrolowanego przyrostu ludności w krajach ubogich. Ich ubóstwo jest postrzegane jako uwarunkowane genetycznie. Por. M. Schooyans, Démographie, contrôle de naissances et crash démographique, dz.cyt., s. 210. 


\section{Część I}

Współczesna sytuacja demograficzna w Polsce

rzecz rozwoju jest zwiąana z określona polityka sanitarna, zakładajaca faktyczne narzucenie silnej kontroli urodzin. Budzą niepokój zarówno prawodawstwa przewidujące eutanazję, jak i naciski grup krajowych i międzynarodowych żadajacych prawnego jej uznania ${ }^{15}$.

Wspomniani papieże podważają tezę, według której przyrost ludności miałby być bezpośrednią przyczyną ubóstwa, natomiast ograniczenie liczby ludności miałoby sprzyjać gospodarczemu rozwojowi. Na niejednoznaczność tego powiązania zwracał uwagę Jan Paweł II: Nie można zaprzeczyć, że istnieje, zwłaszcza w strefie Południa naszej planety, problem demograficzny utrudniajacy rozwój. Warto tu zaznaczyć, że w strefie Pótnocy ten problem ma cechy odwrotne: tam niepokoi spadek przyrostu urodzeń $i$ zwiąane z tym starzenie się ludności, niezdolnej do biologicznej odnowy. Zjawisko to samo w sobie utrudnia rozwój. Tak jak nie jest ścisłe twierdzenie, że trudności pochodza jedynie z wyżu demograficznego, tak nie zostało również dowiedzione, że każdy wzrost demograficzny nie da się pogodzić z planowanym rozwo$j^{16}{ }^{16}$. Benedykt XVI natomiast pisał: Błędem jest uważanie

15 Benedykt XVI, Caritas in veritate, 28. Dwie największe organizacje pozarządowe zaangażowane w ograniczanie przyrostu ludności w krajach ubogich to International Planned Parenthood Federation oraz Marie Stopes International. Są one finansowane głównie przez ONZ, Stany Zjednoczone oraz prywatne fundacje, jak Fundacja Rockefelera, Fundancja Billa i Melindy Gates, Fundacja Georges'a Sorosa. Por. M. Schooyans, Démographie, contrôle de naissances et crash démographique, dz. cyt., s. 209; G. Kuby, Globalna rewolucja seksualna. Likwidacja wolności w imię wolności, Kraków 2013, s. 90-91.

16 Jan Paweł II, Sollicitudo rei socialis, 25. Wszyscy zdaja sobie sprawe, z aktualności i wzrastającej powagi owego zjawiska w krajach uprzemysłowionych. Jeśli wydaje się ono alarmujace w krajach na drodze rozwoju, przy ich dużym przyroście demograficznym $i$ wielkiej liczbie ludzi młodych, to w przypadku krajów o wysokim. rozwoju ekonomicznym odnosi się: wrażenie, że kurcza się miejsca pracy $i$ w ten sposób możliwości zatrudnienia zamiast wzrastać, maleja. Również to zjawisko, któremu towarzyszy szereg ujemnych skutków na płaszczyźnie indywidualnej i społecznej, od degradacji aż po utrate szacunku, jaki każdy człowiek winien żywić dla samego siebie, skłania nas do poważnego pytania o to, z jakiego typu rozwojem mieliśmy do czynienia w ciagu ostatnich dwudziestu lat. W zwiazku z tym nasuwa się jakże tu stosowna myśl $z$ Encykliki Laborem exercens: 'Należy podkreślić, że elementem konstytutywnym, a zarazem najwłaściwszym sprawdzianem owego postępu w duchu spra- 


\section{Część I}

Współczesna sytuacja demograficzna w Polsce

wzrostu ludności za pierwsza przyczynę niedorozwoju, również z punktu widzenia ekonomicznego: wystarczy wspomnieć $z$ jednej strony poważne zmniejszenie śmiertelności dzieci i przedtużenie średniej wieku, dostrzegalne w krajach rozwiniętych gospodarczo; z drugiej oznaki kryzysu dostrzegalne w społeczeństwach, w których obserwuje się niepokojacy spadek narodzin. (...) Moralnie odpowiedzialne otwarcie na życie stanowi bogactwo społeczne i ekonomiczne. Wielkie narody mogły wyjść ze swej nędzy również dzięki wielkiej liczbie i zdolnościom swoich mieszkańców. I przeciwnie, narody niegdyś kwitnace doświadczaja obecnie fazy niepewności, a w niektórych przypadkach upadku właśnie z powodu zmniejszenia liczby urodzin, będacego kluczowym problemem społeczeństw zaawansowanego dobrobytu. Zmniejszenie się liczby urodzin, niekiedy poniżej tak zwanego "wskaźnika wymiany», powoduje również kryzys systemów opieki społecznej, zwiększa jej koszty, pomniejsza nagromadzone oszczędności $i w$ rezultacie środki finansowe potrzebne do inwestycji, redukuje liczbe kwalifikowanych pracowników, zacieśnia zasoby «mózgów», do których można sięgać dla potrzeb narodu. Ponadto mate, a czasem bardzo mate rodziny sa narażone na ryzyko zubożenia więzów społecznych i niemożności zagwarantowania skutecznych form solidarności. Sa to sytuacje ujawniajace symptom ograniczonego zaufania wobec przyszłości, jak również zmęczenia moralnego ${ }^{17}$.

wiedliwości i pokoju, który Kościół głosi i o który nie przestaje się modlić (...) jest właśnie stałe dowartościowywanie pracy ludzkiej, zarówno pod katem jej przedmiotowej celowości, jak też pod kątem godności podmiotu każdej pracy, którym jest człowiek'. Co więcej, 'nie może nas nie uderzać niepokojacy fakt o ogromnych wymiarach', a mianowicie, że 'istnieja całe zastępy bezrobotnych czy też nie w petni zatrudnionych (...) fakt, który niewatpliwie dowodzi, że zarówno wewnątrz poszczególnych wspólnot politycznych, jak $i$ we wzajemnych stosunkach między nimi na płaszczyźnie kontynentalnej i światowej - gdy chodzi o organizacje pracy $i$ zatrudnienia - coś nie działa prawidłowo, i to właśnie w punktach najbardziej krytycznych i o wielkim znaczeniu społecznym'. Tak jak poprzednie, tak $i$ to zjawisko, ze względu na jego powszechność i szybkie narastanie, stanowi bardzo wyraźny wskaźnik, o wydźwięku negatywnym, dzisiejszego stanu i jakości rozwoju ludów (Jan Paweł II, Sollicitudo rei socialis, 18).

17 Benedykt XVI, Caritas in veritate, 44. 
2. Rola państwa i organizacji międzynarodowych w zakresie polityki demograficznej

Czy z powyższego wynika, że rządy państw i organizacje międzynarodowe powinny się całkowicie wycofać z prób wpływania na procesy demograficzne? Wydaje się, że oczekiwanie Kościoła jest wręcz przeciwne. Chodzi jedynie o to, aby zdawać sobie sprawę, że aktualna, oparta na błędnych naukowych teoriach, polityka antynatalistyczna nie ma wiele wspólnego $\mathrm{z}$ autentyczną pomocą na rzecz rozwoju, a być może jest wręcz przeciw-skuteczna. Papież Paweł VI pisał: Nie ulega watpliwości, że władze publiczne w granicach swej kompetencji moga w tej sprawie interweniować, udzielając obywatelom odpowiednich pouczeń i podejmując stosowne decyzje, byle tylko byty one zgodne z nakazami prawa moralnego i szanowaty w całej petni uprawniona wolność małżonków ${ }^{18}$. Zalecenia w podobnym duchu można znaleźć w tekście Gaudium et spes: Do rzadu należa prawa $i$ obowiązki odnoszace się do problemu populacji w jego narodzie, w granicach właściwej mu kompetencji, na przykład co do ustawodawstwa społecznego i rodzinnego, migracji mieszkańców wsi do miast, informacji o stanie i potrzebach narodu. (...) Ponieważ wielu jest zdania, że wzrost liczby ludności świata, albo przynajmniej niektórych narodów, powinien być drastycznie ograniczony przy użyciu wszystkich środków i wszelkiego interwencji władzy publicznej, Sobór wzywa wszystkich, aby wystrzegali się zalecanych prywatnie lub publicznie, a niekiedy wprost narzucanych rozwiazań, które sprzeciwiaja się prawu moralnemu ${ }^{19}$.

Główny problem z polityką demograficzną na poziomie narodowym i międzynarodowym polega zatem na lekceważeniu godności i wolności małżonków oraz na niegodziwości stosowanych instrumentów. Mamy zatem, z jednej strony, próbę odgórnego wymuszania na rodzicach decyzji o liczbie dzieci i chwili ich narodzenia,

18 Paweł VI, Populorum progressio, 37.

19 Sobór Watykański II, Gaudium et spes, 87. 
z drugiej zaś, nachalne promowanie antykoncepcji, sterylizacji i aborcji. Niekiedy przybiera ono formę policyjnego wymuszania decyzji na konkretnych osobach, jak w przypadku chińskiej „polityki jednego dziecka”, lub na uwarunkowywaniu pomocy dla rozwoju udzielanej przez organizacje międzynarodowe i poszczególne państwa od przyjęcia przez konkretne rządy antynatalistycznej polityki. Kluczowym terminem wykorzystywanym do promocji polityki antynatalistycznej jest tzw. zdrowie (i prawa) reprodukcyjne. Eufemizmy te, spopularyzowane za sprawą konferencji ludnościowej w Kairze (1994), służą, między innymi, do wymuszania zmian prawnych przeciwko życiu ludzkiemu oraz promocji w krajach ubogich antynatalistycznych programów edukacji seksualnej ${ }^{20}$.

Innym etycznie wątpliwym elementem polityki antynatalistycznej jest deprecjonowanie instytucji małżeństwa i rodziny. Jest to, jak się wydaje, prostą konsekwencją „,sterylizacji" ludzkiej seksualności. Jeśli bowiem z kontekstu współżycia między mężczyzną i kobietą wyeliminuje się możliwość poczęcia dziecka, trudno zrozumieć zarówno potrzebę zagwarantowania trwałości więzi małżeńskiej, jak i konieczność ograniczenia instytucji małżeństwa do związków osób odmiennej płci. Warto przypomnieć, że w historii zarówno opóźnianie małżeństwa (T.R. Malthus), jak i propagowanie relacji homoseksualnych (J. Bentham: the improlific appetite) były proponowane jako środki zapobiegające przeludnieniu.

20 Por. Report of the International Conference on Population and Development, Cairo, 1994. Programme of Action, Chapter 7, Reproductive rights and reproductive health, Principles of action, § 7.2, <http://www.un.org/popin/ icpd/conference/offeng/poa.html>. Por. Programme of Action, $\S 13.14$ i § 8.25: "Basic reproductive health services (...) would include the following major components, which should be integrated into national basic programmes for population and reproductive health: (...) b) (...) abortion, as specified in paragraph 8.25" (\$13.14). In circumstances where abortion is not against the law, such abortion should be safe (§ 8.25). Por. COMECE, The term 'sexual and reproductive health' and its meaning at international and Euroeapn levels, w: COMECE, Science $\mathcal{E}$ Ethics, volume 2: Collection of opinions prepared by the Bioethics Reflection Group, 2012, <http://www.comece.eu/site/en/ publications/pubsec/article/4999.html>. 


\section{Część I}

Współczesna sytuacja demograficzna w Polsce

W reakcji na te ideologiczne postulaty, Kościół przypomina, po pierwsze, o niezbywalnym prawie mężczyzny i kobiety do zawarcia związku małżeńskiego oraz do swobodnego i odpowiedzialnego decydowania o liczbie i momencie przyjścia na świat dzieci. Skoro bowiem niezaprzeczalne prawo do małżeństwa $i$ do prokreacji zostaje odjęte, nie ma już mowy o godności ludzkiej. Wreszcie jest rzecza rodziców z pełnym rozeznaniem ustalać liczbę dzieci; przyjmuja oni na siebie to zadanie wobec Boga, wobec siebie samych, wobec dzieci już urodzonych $i$ wobec społeczności, do której należa, idąc za nakazem swego sumienia, pouczonego o prawie Bożym, autentycznie tłumaczonym i umocnionego ufnościa w Bogu ${ }^{21}$. Zadaniem państwa jest stworzenie warunków sprzyjających właściwemu kształtowaniu sumienia oraz zdobyciu wiedzy koniecznej do podejmowania odpowiedzialnych decyzji o prokreacji. Albowiem, zgodnie z niezbywalnym prawem człowieka do małżeństwa i prokreacji, decyzja o liczbie potomstwa zależy od stusznego osadu rodziców i w żadnym wypadku nie może być pozostawiana władzy publicznej. Ponieważ zaś ocena rodziców zakłada prawidłowe ukształtowanie ich sumień, jest rzecza wielkiej wagi, aby wszyscy uzyskali możliwość rozwoju właściwej i prawdziwie ludzkiej odpowiedzialności, która kierowałaby się prawem Boskim, z uwzględnieniem okoliczności miejsca i czasu; to zaś wymaga, aby warunki pedagogiczne i społeczne wszędzie zmieniały się na lepsze, a przede wszystkim, aby umożliwiono ludziom uzyskanie formacji religijnej albo przynajmniej petnego wychowania moralnego. Ludzie powinni w sposób madry dowiadywać się o dalszych postępach nauki w zakresie poszukiwania metod, które moga pomagać matżonkom w decydowaniu o liczbie potomstwa, metod pewnych i zgodnych z porzadkiem moralnym ${ }^{22}$.

Deprecjonowanie przez państwa i instytucje międzynarodowe małżeństwa i rodziny wynika z całkowitego zapoznania roli i znaczenia tych instytucji dla życia społecznego i państwowego. Dziecko jest dobrem nie tylko

$21 \quad$ Paweł VI, Populorum progressio, 37.

22 Sobór Watykański II, Gaudium et spes, 87. 
„dla" rodziców. Jest dobrem także „dla” społeczeństwa. Macierzyństwo nie jest tylko sprawą prywatną. Jest dobrem wnoszonym do życia społecznego. Są to tezy dobrze dziś przyswojone zarówno przez nauki społeczne, jak i ekonomiczne ${ }^{23}$. Dlatego też - pisze Benedykt XVI - staje się koniecznościa społeczna, a nawet ekonomiczna, ponowne proponowanie nowym pokoleniom piękna rodziny i małżeństwa, oraz że instytucje te odpowiadaja na najgłębsze potrzeby serca $i$ godności osoby. W tej perspektywie zadaniem państw jest prowadzenie polityki, która promuje centralny charakter i integralność rodziny, opartej na małżeństwie mężczyzny i kobiety, będacej pierwsza i żywotna komórka społeczeństwa, troszczac się także o jej problemy ekonomiczne i fiskalne, z poszanowaniem jej natury relacyjnej ${ }^{24}$.

Paradoksalnie, w aktualnej debacie publicznej pozytywne opinie na temat posiadania dzieci padają niemal wyłącznie w kontekście dyskusji na temat zapłodnienia in vitro, matek zastępczych oraz ewentualnego prawa do adopcji przez osoby żyjące w związkach jednej płci. W głównym nurcie debaty ludzka płodność przedstawiana jest raczej jako potencjalne zagrożenie, przed którym należy się możliwie skutecznie „zabezpieczyć”. „Ubezpłodnienie" współżycia seksualnego między mężczyzną i kobietą powoduje, że w kulturze masowej przedstawiane jest ono w kontekście dążenia do maksymalizacji doświadczenia przyjemności zmysłowej, czemu sprzyjać „powinna" edukacja seksualna sprowadzona do znajomości pewnych technik oraz zasad higieny ${ }^{25}$. W tym kontekście

23 Por. G.S. Becker, A Treatise on the Family, Cambridge, Massachusetts 1994; P. Donati, Famiglia - risorsa della societa, Bologna 2012; P. Donati, La famiglia - il genoma che fa vivere la societa, Rubbettino 2013; R. Prandini, Politiche familiari europee. Convergenze e divergenze, Roma 2012; K. Bogenschneider, Family Policy Matters. How policymaking affects families and what professionals can do, New York 2014.

24 Benedykt XVI, Caritas in veritate, 44.

25 Por. UNESCO, International Technical Guidance on Sexuality Education. An evidence-informed approach for schools, teachers and health educators, $<$ http://unesdoc.unesco.org/images/0018/001832/183281e.pdf>; Biuro Regionalne WHO dla Europy i BZgA, Standardy edukacji seksualnej w Europie. Podstawowe zalecenia dla decydentów oraz specjalistów zajmujacych się 
należy chyba odczytywać słowa Benedykta XVI zawarte w Caritas in veritate: Kościót, któremu leży na sercu prawdziwy rozwój człowieka, zaleca mu pełne poszanowanie wartości ludzkich, także w korzystaniu z ptciowości. Nie można jej sprowadzić do zwykłego faktu hedonistycznego czy zabawy, podobnie jak nie można sprowadzić wychowania seksualnego do instrukcji technicznej, troszczac sie jedynie o obrone zainteresowanych przed ewentualnym zarażeniem się czy przed «ryzykiem» prokreacyjnym. Byłoby to równoważne ze zubożeniem i pominięciem głębokiego znaczenia płciowości, który powinien być uznany $i$ przyjęty z odpowiedzialnościa zarówno ze strony osoby, jak $i$ wspólnoty. Odpowiedzialność zabrania bowiem zarówno traktowania płciowości jako zwykłego źródła przyjemności, jak i regulowania jej przez polityke przymusowego planowania narodzin. Wobydwu przypadkach mamy do czynienia z politykami i działaniami materialistycznymi, w których osoby doświadczaja w końcu różnych form przemocy. Temu wszystkiemu trzeba przeciwstawić pierwszorzędna kompetencje rodzin na tym polu, w odniesieniu do państwa i jego polityki restrykcyjnej, a także odpowiednią edukację rodziców $w^{26}$.

\section{Płodność jako błogosławieństwo}

Człowiek nie potrafi żyć bez miłości ${ }^{27}$. Stanowi to najgłębszy powód, dla którego mężczyzna opuszcza ojca swego i matke swoja i łaczy się ze swoja żona tak ściśle, że staja się jednym ciałem $(\mathrm{Rdz} 2,24)$. W ten obrazowy sposób Księga Rodzaju wyjaśnia genezę instytucji małżeństwa i niezwykłej więzi, która każe opuścić rodziców, by założyć nowa, własną rodzinę ${ }^{28}$. Cielesne zjednoczenie Biblia nazywa także „poznaniem” (hebr. jada). Mężczyzna „poznał" swoją żonę Ewę, ona zaś poczęła i urodziła syna

edukacja $i$ zdrowiem, <http://issuu.com/undp_poland/docs/who_bzga_ standardy_edukacji_seksualnej/63>.

26 Benedykt XVI, Caritas in veritate, 44.

27 Jan Paweł II, Redemptor hominis, 10.

28 Por. W. Chrostowski, Płeć jest darem Boga. Ideologia gender w świetle Pisma Świętego, s. 11. 
(por. Rdz 4,1-2). Jan Paweł II zwraca uwagę na specyficzne znaczenie tego poznania. Odmienna w stosunku do mężczyzny konstytucja kobiety (dziś wiemy, że odmienna aż do najgłębszych determinant biologicznych) w pewnej tylko mierze uwidacznia się na zewnatrz w budowie i kształcie jej ciała. Macierzyństwo ujawnia tę konstytucję do wewnątrz jako szczególna potencjalność całego ustroju kobiecego, który ze stwórcza zaiste precyzja służy poczęciu i zrodzeniu cztowieka za sprawa męż$c z y z n y^{29}$. Poznanie oznacza tutaj odkrycie i zrozumienie, że różnica biologiczna płci ma charakter relacyjny. Ustanowiona jest przez Boga z uwagi na możliwość zrodzenia wspólnie dzieci. Gdyby pominąć kwestię płodności, zdolności do powołania do życia trzeciego człowiek, trudno byłoby zrozumieć, na czym zasadza się różnica płci ${ }^{30}$. Bycie mężczyzną i kobietą nie sprowadza się do odgrywania ról $\mathrm{w}$ teatrze, do przebierania się po to, by przez chwilę udawaćna scenie jakąś postaćliteracką. Kobieta może wprawdzie w teatrze życia społecznego "grać rolę chłopca", a mężczyzna "grać rolę dziewczynki", ale istnieją w tym zakresie naturalne ograniczenia. Można odgrywać role chłopca w łóżku, co nie oznacza, że można odegrać role mężczy$z n y$, który obdarowuje kobiete dzieckiem ${ }^{31}$. Pod widocznym na zewnątrz kostiumem ukrywa się bowiem niezwykle skomplikowane instrumentarium biologiczne przygotowane po to, aby, za współdziałaniem tej jego części, której nosicielem jest mężczyzna, i tej znajdującej się po stronie kobiety, doszło do poczęcia i urodzenia nowego człowie-

29 Jan Paweł II, Katecheza środowa, 12 marca 1980 r., 3.

30 Kobieta wiąże się z mężczyzna jako możliwym towarzyszem i ojcem jej dzieci, mężczyzna wiąże się z kobieta jako możliwa partnerka i matka jego dzieci. Wtaśnie w tym odniesieniu do trzeciego, do tego, którego moga wydać na świat tylko wspólnie, mężczyzna i kobieta określają się jako byty zróżnicowane ptciowo. Jeśli zapomnimy o stosunku do potomstwa, jeśli nie jest on regulowany żadnymi więziami społecznymi, takimi jak małżeństwo i pokrewieństwo, różnica między mężczyznami i kobietami nie jest naprawdę istotna, a tożsamość płciowa traci większe znaczenie. Ojcostwo i macierzyństwo sa najprawdopodobniej decydującymi doświadczeniami różnicy płci i nie jest pewne, czy istnieją inne (S. Agacinski, Polityka płci, Warszawa 2000, s. 153).

31 S. Agacinski, Femmes entre sexe et gendre, Editions du Seuil 2012, s. 105. 


\section{Część I}

Współczesna sytuacja demograficzna w Polsce

$\mathrm{ka}^{32}$. Poczęcie i urodzenie człowieka stanowi w pewnym sensie definitywne odkrycie sensu ludzkiego ciała w konstytutywnej dla niego męskości i kobiecości ${ }^{33}$, to jakby dojście do kresu ukrytej w somatycznych możliwościach mężczyzny i kobiety «przedmiotowości» ciała, a zarazem przedmiotowości człowieka, który «jest» tym ciałem ${ }^{34}$. Otwiera ono zarazem przed człowiekiem perspektywę realizacji siebie poprzez stawanie się „czystym" darem. Tym samym "przyrodnicza” determinacja człowieka poprzez ciało i płeć przestaje być czymś biernym. Zostają one odczytane jako dane przez Boga i zadane człowiekowi, by ten stał się poprzez nie i na sposób właściwy każdej z płci darem w swoim ojcostwie i macierzyństwie ${ }^{35}$.

Uczucia i biologia korespondują ze sobą. Pragnienie zjednoczenia $\mathrm{w}$ miłości budzi chęć posiadania dzieci wspólnie z umiłowaną osobą. Mężczyzna, zauroczony pięknem i dobrem swojej żony, pragnie, by świat zapełnił się istotami na jej „obraz i podobieństwo”. Dzięki temu świat stanie się lepszy i piękniejszy. Kobieta, zauroczona szlachetnym męstwem swojego męża, pragnie, by świat zapełnił się istotami podobnymi do niego. Powiedzenie umiłowanej osobie: „dobrze, że jesteś", prowadzi do odkrycia, że świat będzie lepszy i piękniejszy, jeśli pojawia się na nim kolejne istoty podobne do ciebie. W ten sposób miłość snuje swój chytry plan naprawy świata.

Stwórca mówi: Bądźcie płodni i rozmnażajcie się, abyście zaludnili ziemię i uczynili ją sobie poddana (Rdz 1,28). Księga Rodzaju - zwraca uwagę Jan Paweł II - używa

32 Sylviane Agacinski zwraca uwagę, że zastanawianie się przez niektórych autorów nad tym, czy dwom płciom biologicznym muszą odpowiadać dwie jedynie płcie kulturowe (gender) wynika z zapoznania relacyjnego charakteru płci biologicznej. Pytanie tego typu jest możliwe dopiero, gdy rozważa się płeć w liczbie pojedynczej, w odseparowaniu od siebie, jakby ciało męskie i kobiece nie były sobie relacyjnie przyporządkowane (Por. S. Agacinski, Femmes entre sexe et gendre, dz. cyt., s. 97-98, 105).

33 Jan Paweł II, Katecheza środowa, 5 marca 1980 r., 5.

34 Jan Paweł II, Katecheza środowa, 12 marca 1980 r., 3.

35 Por. tamże, 4. 
w stosunku do człowieka tych samych słów, co przy stworzeniu innych istot żyjących: „rozmnażajcie się”. Jednak ich sens jest jedynie analogiczny. Wprawdzie słowa, których Arystoteles używa do opisu świata zwierząt (Przez samca rozumiemy «zwierze, które rodzi w drugim», a przez samicę "zwierzę, które rodzi w sobie» ${ }^{36}$ ) prawdziwe są także w odniesieniu do mężczyzny i kobiety, ale daleko im do wyczerpania prawdy o ludzkim rodzicielstwie. Biologicznie jest ono podobne do prokreacji innych istot żyjących w przyrodzie, ale istotowo jest ono „podobne” do działania Boga samego ${ }^{37}$. Gdy z małżeńskiej jedności dwojga rodzi się nowy człowiek, to przynosi on z soba na świat szczególny obraz i podobieństwo Boga samego: w biologie rodzenia wpisana jest genealogia osoby ${ }^{38}$. Pozwala to powiedzieć, że małżonkowie jako rodzice są współpracownikami Boga-Stwórcy w poczęciu i zrodzeniu nowego człowieka. Nasze obcowanie ptciowe, niczym cielesna modlitwa, przynagla Wszechmocnego, żeby nadał ostateczna doskonałość zjednoczeniu nas dwojga - pisze Fabric Hadjadj ${ }^{39}$. Nie chodzi tu jednak jedynie o współuczestnictwo w przekazywaniu życia w sensie biologicznym, jak się to dzieje w odniesieniu do zwierząt. W poczęciu człowieka zostaje mu przekazany „obraz i podobieństwo" samego Boga, co może być wyłącznie Jego dziełem. Dokonuje się to, jak mówi kobieta, z pomoca Jahwe $(\operatorname{Rdz} 4,1)^{40}$. W akcie poczęcia i zrodzenia dziecka rodzice są dopuszczeni do uczestnictwa w boskim akcie stworzenia człowieka, który jest na „obraz i podobieństwo" Boga i który pewnego dnia znajdzie się po stronie zbawionych lub potępionych. Dziecko jest jednak także - choć w innym sensie - na obraz i podobieństwo matki

\footnotetext{
36 Arystoteles, O rodzeniu się zwierzat, w: Arystoteles, Dzieła wszystkie, t. 4, Warszawa 1993, s. 101.

37 Por. Jan Paweł II, List do rodzin, 6.

38 Tamże, 9.

39 F. Hadjajd, Kobieta i mężczyzna. O mistyce ciała, Poznań 2013, s. 193.

40 W trakcie zawierania sakramentu małżeństwa celebrans pyta narzeczonych w imieniu Kościoła: Czy chcecie z miłościa przyjąc i po katolicku wychować potomstwo, którym Bóg was obdarzy? (Rituale Romanum. Ordo celebrandi matrimonium, n. 60, editio typica altera, 1991, s. 17).
} 


\section{Część I}

Współczesna sytuacja demograficzna w Polsce

i ojca. Rodzenie sprawia, że «mężczyzna i kobieta (jego żona)» poznaja się wzajemnie w tym "trzecim», który jest z nich dwoj$g a^{41}$. Rozpoznają w nim „żywy obraz" każdego z nich, a także łączącej ich miłości. O tej nowej istocie mogą wspólnie powiedzieć: kość z moich kości i ciało z mego ciała (por. Rdz 2,24) ${ }^{42}$.

Ludzka miłośćnieustannie zmaga się z egoizmem. Małżonkowie chcą dzieci, ale - jak notuje Jan Paweł II - chcą ich "dla siebie", widząc w nich zwieńczenie wzajemnej miłości ${ }^{43}$. Bóg tymczasem chce człowieka dla niego samego ${ }^{44}$. Odnosi się to do każdej ludzkiej istoty. Również do osoby chronicznie chorej, urodzonej z głębokim upośledzeniem czy niedorozwojem. Również jej istnienie zakorzenione jest w odwiecznej miłości Boga (por. Jr 31,3). Również ona powołana jest, aby „być człowiekiem" na miarę daru, jaki otrzymała. Na miarę tego „,talentu”, którym jest samo człowieczeństwo, a dopiero potem na miarę wszystkich talentów szczegółowych, jakimi została obdarzona ${ }^{45}$. Trzeba, ażeby w to chcenie Boga - pisze Jan Paweł II - włączało się ludzkie chcenie rodziców: aby oni chcieli nowego człowieka, tak jak go chce Stwórca. Ludzkie chcenie zawsze poddane jest prawu czasu, prawu przemijania. Boże - jest odwieczne. «Zanim ukształtowałem cię w tonie matki, znałem cię - mówi prorok Jeremiasz - nim przyszedłeś na świat, poświęciłem cię» (Jr 1,5). Genealogia osoby jest naprzód związana z wiecznościa Boga, a potem dopiero z momentem ludzkiego rodzicielstwa. Już $w$ samym poczęciu człowiek jest powołany do wieczności w Bogu ${ }^{46}$. Małżonkowie wezwani są do tego, aby uczyć się chcieć dziecka "dla niego samego", aby słowa, jakie skierowali do siebie nawzajem: „dobrze, że jesteś”, pewnego dnia wypowiedzieć także pod adresem swojego dziecka. „Dobrze, że jesteś" - to nie tylko odczytanie, że płodność jest

\footnotetext{
Jan Paweł II, Katecheza środowa, 12 marca 1980 r., 4.

Por. Jan Paweł II, Katecheza środowa, 26 marca 1980 r., 3.

Por. Jan Paweł II, List do rodzin, 9.

Sobór Watykański II, Gaudium et spes, 24.

Por. Jan Paweł II, List do rodzin, 9.

Tamże.
} 


\section{Część I}

Współczesna sytuacja demograficzna w Polsce

błogosławieństwem, ale przede wszystkim odkrycie, że w przypadku ludzkiej płodności nie chodzi po prostu, jak w przypadku zwierząt, o rozmnażanie, ale o miłość, która jest twórcza. Communio personarum poprzedza - w sensie ontycznym - płodność 47 .

Miłość między mężczyzną i kobieta, zgodnie z jej wewnętrzną logiką uczynienia z siebie daru dla drugiej osoby, prowadzi do zawarcia małżeństwa i założenia rodziny. Współżycie męża i żony sprawia, że na świat przychodzą dzieci jako owoc wzajemnej miłości. Otwartość na życie jest znakiem otwartości na współmałżonka i otwartości na wolę Boga. Pełny akt ptciowy, jak pisze Fabric Hadjadj, to akt płodny. Z teściowa w tle, z wnukami w perspektywie ${ }^{48}$. Sterylizacja relacji heteroseksualnych w wyobraźni społecznej za sprawą upowszechnienia antykoncepcji i aborcji sprawia, że współczesnym coraz trudniej jest zrozumieć w sposób wystarczająco głęboki naturę relacji między mężczyzną i kobieta, co sprzyja, z jednej strony, banalizacji seksu, z drugiej zaś, prowadzi do niezaspokojenia serca poszukującego prawdziwej miłości.

Twórczość ludzkiej miłości przejawia się w powołaniu do życia rodziny. Dzieci mają niezwykle ważną rolę do odegrania w historii małżeńskiej miłości. Już Arystoteles zauważył: Dodatkowym węzłem łączacym ich (małżonków) zdaja się być dzieci (dlatego matżeństwa bezdzietne szybko się rozchodza); wszak dzieci sa wspólnym ich dobrem, a to, co wspólne, stanowi więźt ${ }^{49}$. Nie jest więc jasne, czy aktualny kryzys małżeństwa i rodziny w Europie jest przyczyną

47 Por. Y. Semen, La préparation au mariage selon Jean-Paul II et la théologie du corps, Presses de la Renaissance, Paris 2013, s. 128-129; Mężczyzna nie ma jednoczyć się z żona po to, żeby spłodzić potomka - w ten sposób uprzedmiotowiałby ją. Ale kiedy mężczyzna i kobieta dąża do jak najściślejszego zjednoczenia, na przedłużeniu dróg, które prowadza ich ku sobie nawzajem, pojawia się dziecko, pogłębiając ich jedność. Kobieta i mężczyzna, obcując cieleśnie, tworza jedno ciało - nowe i osobne (F. Hadjajd, Kobieta i mężczyzna. O mistyce ciała, dz. cyt., s. 194).

48 F. Hadjadj, Kobieta i mężczyzna. O mistyce ciała, dz. cyt., s. 30.

49 Arystoteles, Etyka nikomachejska, w: Arystoteles, Dzieła wszystkie, t. 5, Warszawa 1996, s. 255. 
braku dzieci, czy też brak dzieci jest źródłem kryzysu i słabości małżeństwa i rodziny. Zbudowana na fundamencie małżeństwa, głębokiego i uzupełniającego się związku mężczyzny i kobiety, otwartego na przekazywanie życia, rodzina jest podstawową komórką życia społecznego ${ }^{50}$. Jest ona pierwszym miejscem humanizacji ${ }^{51}$. W niej człowiek otrzymuje pierwsze $i$ decydujące wyobrażenia zwiazane z prawda i dobrem, uczy się, co znaczy kochać i być kochanym, a więc co konkretnie znaczy być osobą ${ }^{52}$. Rodzina jest czymś więcej niż tylko zwykłą jednostką prawną, społeczną czy ekonomiczną. Stanowi wspólnotę miłości i solidarności, unikalną pod względem możliwości nauczania i przekazywania wartości kulturalnych, etycznych, społecznych, duchowych i religijnych, istotnych dla rozwoju i powodzenia własnych członków oraz społeczeństwa. Jest miejscem spotkania różnych pokoleń, które pomagają sobie wzajemnie w osiąganiu pełniejszej mądrości życiowej oraz w godzeniu praw poszczególnych osób z wymaganiami życia społecznego. Solidarność pokoleń, z jaką spotykamy się w rodzinie, jest szczególnie ważna w obliczu zjawiska starzenia się społeczeństw. Sprzyja bowiem łagodzeniu społecznych napięć ${ }^{53}$.

Rodzina, jako związek naturalny, jest rzeczywistością pierwotną w stosunku do państwa czy jakiejkolwiek innej wspólnoty. Nie istnieje dla społeczeństwa i dla państwa, ale społeczeństwo i państwo istnieja dla rodziny ${ }^{54}$. Rodzina zatem posiada swoją naturalną tożsamość i swoje własne - nie pochodzące z nadania społeczeństwa czy państwa - niezbywalne prawa, które państwo i społeczeństwo zobowiązane są uszanować.

\footnotetext{
Por. Stolica Apostolska, Karta Praw Rodziny, Preambuła, B.

Jan Paweł II, Christifideles laici, 40.

Jan Paweł II, Centesimus annus, 39.

Por. Stolica Apostolska, Karta Praw Rodziny, Preambuła, D-G.

Papieska Rada „Iustitia et Pax”, Kompendium Nauki Społecznej Kościoła, 214.
} 


\section{Co Kościół może uczynić w dziedzinie demografii?}

Ani dominujący aktualnie model polityki demograficznej, ani też przebieg samych procesów demograficznych $w$ różnych regionach świata nie są obojętne Kościołowi. Jeśli myślimy o roli, jaką może on odegrać w obu tych obszarach, niewątpliwie chodzić tu musi głównie o nauczanie skierowane zarówno do członków społeczności katolickiej, jak i do całych społeczeństw. Nauczanie to powinno obejmować pewne elementy negatywne (wskazujące i piętnujące pewne tendencje i działania) oraz elementy pozytywne (promocja idei i zachowań szanujących możliwie w pełni godność człowieka oraz służących dobru wspólnemu). Zadaniem Kościoła jest więc:

- ujawnianie ideologicznego charakteru polityki antynatalistycznej ufundowanej na mitycznym rozumieniu demografii;

- przeciwstawianie się rasistowskiej ideologii;

- przeciwstawianie się mentalności eugenicznej;

- przeciwstawianie się kulturze hiper-indywidualizmu, egoizmu, hedonizmu itp.;

- dążenie do ustanowiona prawnego zakazu aborcji i przymusowej sterylizacji;

- przeciwstawianie się legalizacji eutanazji dobrowolnej i niedobrowolnej;

- wyjaśnianie szkodliwości redukcji idei wolności kobiet do wolności od męża i dzieci;

- ukazywanie zagrożeń dla zdrowia, integralnego rozwoju osoby oraz ludzkiej miłości niesionych przez antykoncepcję,

- zwalczanie rynku usług prokreacyjnych (handlu „brzuchami” matek zastępczych i handlu dziećmi);

- sprzyjanie autentycznym badaniom naukowym w dziedzinie demografii i oraz jej związków z naukami ekonomicznymi ${ }^{55}$;

55 Ponieważ obecnie problem ten tak silnie angażuje umysty ludzi, jest pożądane, aby kompetentni katolicy, zwłaszcza na uniwersytetach, w sposób przemyśla- 
- promocja autentycznej pomocy dla integralnego rozwoju ${ }^{56}$;

- promocja godności każdej osoby;

- wyjaśnianie natury ludzkiej miłości i małżeństwa;

- promocja instytucji małżeństwa jako trwałego związku jednego mężczyzny i jednej kobiety;

- promocja pozytywnego stosunku do ludzkiej płodności (dzieci jako owoc miłości i dar od Boga);

- promocja rodziny, zwłaszcza rodziny wielodzietnej;

- promocja odpowiedzialnego rodzicielstwa ${ }^{57}$;

- promocja praw rodziców i praw dzieci;

- promocja solidarności międzypokoleniowej;

- promocja poczucia odpowiedzialności za wspólnotę;

- ukazywanie godności osób w podeszłym wieku;

- przypominanie o konieczności globalizacji solidarności.

Europa jest wyjątkowa pod względem demograficznym, choć inne kontynenty - być może - kiedyś podążą jej śladem. Jan Paweł II zwracał uwagę, że Europa jest kontynentem wystawionym na pokusę gaszenia nadziei. Wydaje się bowiem, że czasy, w jakich żyjemy i zwiazane z nimi wyzwania to okres zagubienia. Tylu ludzi sprawia wrażenie, $\dot{z} e$ sa zdezorientowani, niepewni, pozbawieni nadziei, stan ducha

ny prowadzili i coraz szerzej rozwijali podejmowali badania i przedsięwzięcia w tym zakresie (Sobór Watykański II, Gaudium et spes, 87).

56 Prawda rozwoju tkwi w jego integralności: jeśli nie ogarnia całego człowieka $i$ każdego człowieka, rozwój nie jest prawdziwym rozwojem. (...) Tak więc powołanie chrześcijańskie do takiego rozwoju dotyczy zarówno wymiaru przyrodzonego, jak i nadprzyrodzonego; $z$ tego powodu, «kiedy Bóg zostaje zepchnięty na dalszy plan, nasza zdolność rozeznania naturalnego porzadku, celu $i$ "dobra" zaczyna słabnaćc» (Benedykt XVI, Caritats in veritate, 18).

57 G.F. Dumont zwraca uwagę na racjonalny charakter ludzkich decyzji także w dziedzinie płodności. Gdy w 1976 roku premier Gandhi wprowadzała w Indiach zachodnią politykę „,dwójki dzieci”, ludzie nie byli w stanie zrozumieć, dlaczego przy wysokiej śmiertelności dzieci mają ograniczać się jedynie do wydania na świat dwójki dzieci. Negatywna reakcja sprawiła, że, aby przeforsować swoją politykę, rząd musiał się uciec do stosowania narzędzi przymusu. Z drugiej strony, polityka ta przyniosła różne skutki w różnych kastach społecznych (Por. G.-F. Dumont, Démographie, transition démographique et politiques démographiques, dz. cyt., s. 242). 
wielu chrześcijan jest (niestety) podobny ${ }^{58}$. Papież wiąże ten stan ducha z religijną obojętnością i praktycznym agnostycyzmem, powodującym, że wielu Europejczyków żyje bez duchowego zaplecza, niczym spadkobiercy, którzy roztrwonili dziedzictwo pozostawione im przez historię. (...) Z ta utrata chrześcijańskiej pamięci wiąże się swego rodzaju lęk przed przyszłościa. Obraz jutra jest często bezbarwny i niepewny. Bardziej się boimy przyszłości, niż jej pragniemy. Niepokojąca oznaka tego jest między innymi wewnętrzna pustka dręczaca wielu ludzi i utrata sensu życia ${ }^{59}$. Świat ekonomii i polityki potrafi wprawdzie coraz lepiej zadbać o dobrobyt, praworządność czy dostęp do dóbr kultury, udzielając przez to praktycznej odpowiedzi na pytanie, na czym polega dobre życie, ale nie jest zdolny, by podać rację, dlaczego w ogóle warto żyć takim "dobrym” życiem ${ }^{60}$. Jednym z wyrazów i owoców tej egzystencjalnej udręki jest dramatyczny spadek liczby urodzeń, zmniejszenie liczby powołań do kapłaństwa $i \dot{z}$ ycia konsekrowanego, trudności w podejmowaniu definitywnych wyborów życiowych - jeśli nie wprost rezygnacja - również w mał̇̇eństwie ${ }^{61}$. W efekcie Europa jest jedynym kontynentem $\mathrm{z}$ ujemny przyrostem demograficznym. Mamy więc, z jednej strony, do czynienia ze starzeniem się społeczeństw, a z drugiej, z wciąż rosnącym procentem celibatariuszy. Sytuacja jest na tyle dramatyczna, że niektórzy demografowie, starając się poruszyć wyobraźnię czytelników, przywołują mityczną postać Kronosa, który pożerał własne dzieci, aby wyeliminować potencjalnych pretendentów do sukcesji ${ }^{62}$.

W kontekście pokusy gaszenia nadziei szczególnym zadaniem Kościoła w Europie jest przywracanie nadziei mającej swoje źródło w Ewangelii. Charles Péguy porównywał ewangelizację do kropli wody święconej, która, wchodząc do kościoła, ludzie podają sobie i przekazują

\footnotetext{
58 Jan Paweł II, Ecclesia in Europa, 7.

59 Tamże, 7-8.

60 Por. R. Brague, Modérément moderne, Flamamarion 2014, s. 47.

61 Jan Paweł II, Ecclesia in Europa, 8.

62 Por. G.-F. Dumont, Démographie: son implosion en Europe, dz. cyt., s. 226-234.
} 


\section{Część I}

Współczesna sytuacja demograficzna w Polsce

z rąk do rąk, by zrobić znak krzyża. Z ręki do ręki i z końca palca na koniec palca, z pokolenia na pokolenie, aż do końca świata ${ }^{63}$. W ten sposób Miłosierdzie Boga przechodzi „z pokolenia na pokolenie", z ojca na syna i wnuka, z matki na córkę i wnuczkę. Wbrew „kulturze prowizoryczności", aż do końca świata.

63 Por. C. Péguy, Przedsionek tajemnicy drugiej cnoty, Kraków 2007, s. 115116. 


\section{Andrzej Ochocki}

Instytut Socjologii UKSW

\section{Praca zawodowa kobiet jako czynnik zmiany demograficznej}

\section{Wprowadzenie}

$\mathrm{W}$ drugiej połowie $\mathrm{XX}$ w., w krajach osiągających relatywnie wyższy poziom dobrobytu społecznego, nastąpiła zmiana demograficzna polegająca na tym, że kolejne pokolenia dzieci są mniej liczne niż pokolenia ich rodziców. Zmianę tę nazwano drugim przejściem demograficznym. Jednym z głównych czynników kształtujących ten proces jest praca zawodowa kobiet.

W artykule dokonano analizy współzależności decyzji matrymonialnych, prokreacyjnych i aktywności zawodowej matek w nawiązaniu do teorii dzietności Gary S. Beckera oraz rzeczywistego przebiegu procesu zastępowalności pokoleń w pięciu państwach: Finlandii, Niemczech, Polsce, Republice Czeskiej i Włoszech. W Finlandii i Niemczech, gdzie osiągnięto podobny poziom dobrobytu społecznego, obserwuje się odmienne tendencje zarówno w zakresie rodności, jak i znaczące różnice w poziomie aktywności zawodowej kobiet wychowujących małe dzieci, co skłania do formułowania nowych hipotez o uwarunkowaniach procesu zastępowalności pokoleń.

Źródłami analizowanych danych są opracowania statystyczne Rady Europy, UNDP, Eurostat'u i badania aktywności zawodowej matek w wybranych krajach Europy przeprowadzone w ramach programu „Dialog” w latach 2000-2003. 


\section{Główne ustalenia teorii dzietności Gary S. Beckera}

Realizowany wzorzec małżeństwa i faktyczna dzietność kobiety jest uwarunkowana różnorodnymi czynnikami płynącymi z otoczenia kulturowego, religijnego, społecznego, ekonomicznego i ekologicznego. Efekt psychologiczny łącznego oddziaływania tych czynników w sferze motywacji i decyzji rodzicielskich kształtuje dominujący model rodziny, a $\mathrm{w}$ konsekwencji przesądza o dynamice demograficznej danego społeczeństwa. Laureat Nagrody Nobla Profesor Gary S. Becker podjął próbę wyjaśnienia mechanizmów decyzji matrymonialnych i prokreacyjnych na gruncie ekonomii w książce pt. A Treatise on the Family $(1981 \mathrm{r} \text {. })^{1}$. W swojej teorii sprecyzował warunek brzegowy możliwych wyborów w sferze zachowań prokreacyjnych, którym jest kategoria pełnego dochodu gospodarstwa domowego. Należy jednak podkreślić, że jego teoria nie traktuje - jak zastrzega sam autor - wyłącznie o materialnych warunkach życia rodzin, ale jest zakorzeniona $\mathrm{w}$ uczuciach moralnych, przyzwyczajeniach i tradycji. Ma ona zastosowanie do opisu zmian zachowań prokreacyjnych, jakie nastąpiły $\mathrm{w}$ okresie ostatnich dwóch stuleci w krajach obecnie wysoko rozwiniętych. Oznacza to, że opisane w tej teorii zależności określają ramy przebiegu procesu podejmowania decyzji prokreacyjnych i rzeczywistą realizację dzietności - w sekularnych tendencjach rozrodczości - w warunkach:

- utrwalenia się niskiej umieralności niemowląt w kolejnych generacjach społeczeństwa,

- upowszechnienia znajomości metod regulacji urodzeń, planowania liczby potomstwa i odstępów proto- $\mathrm{i}$ intergenetycznych,

- ukształtowania w społeczeństwie danego poziomu inwestowania w składniki jakościowe dziecka, które określają jego kapitał ludzki, np. ustanowienie obo-

Por. G.S. Becker, A Treatise on the Family, Harvard University Press, London 1981, s. 38-92, 93-134. 
wiązku szkolnego dzieci, obowiązkowej ochrony macierzyństwa i zdrowia małego dziecka. Warunki te spełniają obecnie kraje Europy i rozwinięte gospodarczo kraje innych kontynentów.

Gary S. Becker stwierdził, że w gospodarstwie domowym wytwarzane są dobra (commodities) na potrzeby jego członków. Zaliczył do nich m.in. zdrowie, autorytet, altruizm, a także satysfakcję z posiadania dzieci. Ugruntowany system wartości $w$ danym społeczeństwie określa preferencje $\mathrm{w}$ zaspokajaniu tych potrzeb $\mathrm{w}$ granicach możliwych wyborów wyznaczonych pełnym dochodem gospodarstwa domowego. Pełny dochód w tym ujęciu odpowiada wartości ekonomicznej czasu rozporządzalnego gospodarstwa domowego w społeczeństwie o danym poziomie dobrobytu: jest sumą dochodów uzyskiwanych z pracy i innych źródeł poza gospodarstwem domowym oraz wartością pieniężną czasu przeznaczonego na wytwarzanie dóbr w gospodarstwie domowym, w tym - na utrzymanie i wychowanie dzieci.

Dążeniem rodziców jest uzyskanie największej satysfakcji (użyteczności) z posiadania określonej liczby dzieci o określonym składniku jakościowym. Maksymalną liczbę dzieci o określonym składniku jakościowym wyznaczają koszty ich utrzymania, które nie mogą być większe niż pełny dochód gospodarstwa domowego. Główną tezą jest natomiast twierdzenie, że $w$ rodzinnym gospodarstwie domowym zachodzi interakcja między ilością urodzonych dzieci a ich składnikiem jakościowym, tzn. stanem zdrowia, wykształceniem, rozwijanymi uzdolnieniami, przyswojonym systemem wartości, poziomem kultury, nabytymi umiejętnościami. Gary S. Becker udowodnił zarazem, że w sytuacji wzrostu pełnego dochodu rodzinnego gospodarstwa domowego rodzice przejawiają większą skłonność do inwestowania w kapitał ludzki dzieci niż do powiększania ich liczby.

Istotne jest też rozróżnienie kosztów stałych i zmiennych utrzymania i wychowania dzieci w gospodarstwie domowym. Koszty stałe to przede wszystkim wyżywie- 
nie, ubranie i higiena osobista. Do kosztów zmiennych zalicza się nakłady poniesione przez rodziców na edukację, prozdrowotny styl życia i ochronę zdrowia, rozwój intelektualny i kulturalny. Analiza zależności między kosztami stałymi i kosztami zmiennymi utrzymania określonej liczby dzieci a skłonnościami rodziców do inwestowania w ich kapitał ludzki dowiodła, że zmniejszenie pożądanej liczby dzieci może być znaczne w sytuacji nawet niewielkiego wzrostu kosztów stałych ze względu na dążenie do sprostania wydatkom decydującym o składniku jakościowym dziecka.

Należy też podkreślić, że w społeczeństwach o rosnącym poziomie dobrobytu społecznego czas przeznaczony przez rodziców na pracę $\mathrm{w}$ domu w związku z wychowywaniem dziecka relatywnie zwiększa swoją wartość ekonomiczną. Z tego powodu tzw. koszty alternatywne macierzyństwa i ojcostwa rosną w sytuacji podwyższania standardu życia, co również powoduje ograniczenie dzietności, ponieważ w społeczeństwie upowszechniają się określone wzorce kosztowniejszej konsumpcji.

Reasumując, można stwierdzić, że w społeczeństwie zwiększającym swój dobrobyt zmniejsza się liczba dzieci w rodzinie, ale zwiększa się ich kapitał ludzki.

Czy zatem skazani jesteśmy na transformację demograficzną bez możliwości powrotu do sytuacji, w której pokolenia dzieci będą co najmniej tak samo liczne jak pokolenia ich rodziców, ponieważ powszechnym dążeniem współczesnych społeczeństw jest poprawa warunków życia, a ich źródłem jest praca człowieka? Teoria Gary S. Beckera uzasadnia, że przywrócenie prostej zastępowalności pokoleń jest możliwe pod warunkiem powiększania dobrobytu społecznego, co umożliwia wzrost pełnego dochodu gospodarstwa domowego, który jest niezbędną przesłanką pozytywnej zmiany zachowań prokreacyjnych generacji wstępujących w wiek matrymonialny. 


\section{Rodzicielstwo a praca}

Rodzicielstwo i pracę łączy w szczególny sposób czas będący do dyspozycji matki i ojca w fazie rozwojowej rodziny aż do momentu usamodzielnienia się ostatniego dziecka, a zwłaszcza wychowywania dzieci w okresie niemowlęctwa i w wieku przed podjęciem nauki w szkole. Rozważenie tych dwóch sfer życia człowieka w kontekście zachowań matrymonialnych i prokreacyjnych ludności ma niewątpliwie istotne znaczenia dla formułowania rozwiązań w zakresie polityki rodzinnej. Jan Paweł II tak oto ujmował tę kwestię: (...) polityka rodzinna musi być filarem $i$ motorem wszelkiej polityki społecznej. Dlatego należy podejmować działania społeczne i prawodawcze zdolne zapewnić warunki autentycznej wolności w podejmowaniu decyzji dotyczacych ojcostwa i macierzyństwa; konieczne jest też oparcie na nowych zasadach polityki w sferze pracy, rozwoju miast, budownictwa mieszkaniowego i ustug, tak aby można było pogodzić rytmy pracy z rytmem życia rodzinnego oraz zapewnić rzeczywista opieke dzieciom i starcom ${ }^{2}$.

Anna Giza-Poleszczuk podkreśla, że: (...) jeśli podstawowym dobrem wytwarzanym przez rodzine jest dziecko, to ten fakt niejako skazuje kobiete na specjalizacje domowa ${ }^{3}$. Uruchomienie procesu owej specjalizacji w okresie macierzyństwa zwiększa przewagę komparatywną pracy kobiety $\mathrm{w}$ domu $\mathrm{w}$ porównaniu $\mathrm{z}$ mężczyzną, a przez to podnosi efektywność inwestowania w kapitał ludzki własnych dzieci, przy jednoczesnym ograniczeniu aktywności zawodowej kobiet na rynku pracy. Problem polega jednak na tym, że praktyczna alokacja czasu rozporządzalnego matki i ojca na rynku pracy i w gospodarstwie domowym przebiega $\mathrm{w}$ określonych warunkach cywilizacyjnych i kulturowych współczesnych społeczeństw, które cha-

\footnotetext{
2 Jan Paweł II, Evangelium vitae, nr 90, w: Encykliki Ojca Świętego Jana Pawła II, Wydawnictwo „Znak”, Kraków 2005, s. 965.

3 A. Giza-Poleszczuk, Rodzina a system społeczny. Reprodukcja i kooperacja w perspektywie interdyscyplinarnej, Wydawnictwo Uniwersytetu Warszawskiego, Warszawa 2005, s. 210.
} 
rakteryzują się odmiennymi systemami wartości i preferencji życiowych ludzi, a w związku z tym, urodzenie się pierwszego i kolejnych dzieci jest uwarunkowane splotem różnorodnych czynników, w tym także aktywnością zawodową kobiety.

Analiza - w retrospekcji trzydziestu lat - zmian natężenia zawierania pierwszych małżeństw, dzietności, aktywności zawodowej matek wychowujących małe dzieci i poziomu dobrobytu społecznego, opisanego za pomocą wskaźnika Sena w pięciu krajach europejskich, nie potwierdziła zależności między tymi procesami ${ }^{4}$. Okazało się bowiem, że nie stwierdzono zależności między poziomem aktywności zawodowej matek wychowujących małe dziecko a poziomem dzietności w Niemczech i Finlandii. Frakcja matek wychowujących dzieci w wieku do 5 lat, które pracowały zarobkowo w pełnym lub niepełnym wymiarze czasu, wynosiła w Finlandii około 66\%, a w Niemczech - 46\%. Zmiany zachowań matrymonialnych przebiegały we wszystkich analizowanych krajach w kierunku osłabienia skłonności do zawierania małżeństw, a jednocześnie $\mathrm{w}$ czterech $\mathrm{z}$ nich utrwalał się proces zawężonej zastępowalności pokoleń. Świadczą o tym wartości współczynników pierwszych małżeństw i dzietności w analizowanym okresie. Otóż utrwalenie się częstości zawierania pierwszych małżeństw na poziomie 2004 roku oznacza, że - w zależności od kraju - więcej niż $30 \%$ kobiet nie zawrze nigdy małżeństwa, jeżeli nie nastąpi zmiana zachowań matrymonialnych. Z kolei, wartości współczynników dzietności w Niemczech, Polsce, Republice Czeskiej i Włoszech obniżyły się w okresie trzydziestu lat do poziomu 1,2 -1,3, co oznacza, że pokolenie dzieci będzie mniej liczne niż pokolenie rodziców o około $40 \%$, jeżeli zachowania prokreacyjne nie ulegną zmianie. Jedynie w Finlandii odwrócono tendencję zmian zacho-

4 Por. A. Ochocki, Rodzicielstwo a praca, w: Kobieta, Etyka, Ekonomia, red. E. Ozorowski, R.C. Horodeński, Wydawnictwo Wyższej Szkoły Ekonomicznej w Białymstoku, Białystok 2009, s. 167-178. 
wań prokreacyjnych w kierunku prostej zastępowalności pokoleń, kiedy pokolenie dzieci jest tak samo liczne jak pokolenie ich rodziców (tabl. 1).

Tablica 1. Pierwsze małżeństwa, współczynnik dzietności, aktywność zawodowa matek wychowujących dzieci w wieku do 5 lat i wskaźnik Sena w wybranych krajach Unii Europejskiej (1970-2005)

\begin{tabular}{|c|c|c|c|c|c|c|}
\hline \multirow{3}{*}{ Kraj } & $\begin{array}{c}\text { Pierwsze } \\
\text { małżeństwa }\end{array}$ & \multicolumn{7}{c|}{ Dzietność } & $\begin{array}{c}\text { Praca } \\
\text { matek }^{1}\end{array}$ & $\begin{array}{c}\text { Wskaź- } \\
\text { nik } \\
\text { Sena }\end{array}$ \\
\cline { 2 - 7 } & \multicolumn{5}{|c|}{ współczynniki lub odsetki w latach } \\
\cline { 2 - 7 } & 1970 & 2004 & $\begin{array}{c}1970 / \\
1975\end{array}$ & $\begin{array}{c}2000 / \\
2005\end{array}$ & $\begin{array}{c}2000 / \\
2003\end{array}$ & 2004 \\
\hline Finlandia & 0,94 & 0,68 & 1,6 & 1,8 & 66,3 & 9284 \\
\hline Niemcy & 0,98 & 0,55 & 1,6 & 1,3 & 46,5 & 9845 \\
\hline Polska & 0,91 & 0,56 & 2,3 & 1,3 & 49,3 & 4585 \\
\hline $\begin{array}{c}\text { Rep. } \\
\text { Czeska }\end{array}$ & 0,91 & 0,48 & 2,2 & 1,2 & 34,2 & 6192 \\
\hline Włochy & 1,01 & 0,6 & 2,3 & 1,3 & 54,2 & 9088 \\
\hline
\end{tabular}

1/ Odsetek matek wychowujących dzieci w wieku do 5 lat pracujących $\mathrm{w}$ pełnym lub niepełnym wymiarze czasu,

2/ Wskaźnik Sena jest miernikiem dobrobytu uwzględniającym przeciętne dochody lub wydatki gospodarstw domowych na osobę, skorygowane współczynnikiem koncentracji Giniego; podane w tablicy wielkości wyrażono w jednostkach PPP, czyli standardowej jednostce nabywczej ustalonej dla wszystkich krajów Unii Europejskiej na podstawie parytetu siły nabywczej walut (PPP), która odpowiada jednakowej ilości kupowanych towarów i usług konsumpcyjnych w każdym kraju.

Źródło: Human Development Report 2001. Making new technologies work for human development, UNDP, New York, tabl. 12, s. 182; Human Development Report 2007/2008. Fighting climate change: Human solidarity in a divided world, UNDP, New York, tabl. 5, s. 246; tabl. 15, s. 281; Europe in figures. Eurostat Yearbook 2006-2007, tabl. 4.2, s. 121; Recent demographic developments 2000, Council of Europe Publishing, T2.2, s. 57; Rocznik Demograficzny 2007, Główny Urząd Statystyczny, Warszawa, tabl. 13 (246); I.E. Kotowska, Work and Parenthood: main findings of comparative data analysis and some policy implications, "Studia Demograficzne" (2005), nr 2/148, s. 60; obliczenia własne. 
Na tej podstawie można wysunąć hipotezę, że dzietność kobiet i aktywność zawodowa na rynku pracy matek wychowujących małe dzieci jest uwarunkowana zarówno poziomem dobrobytu danego społeczeństwa, jak i rozwiązaniami w polityce rodzinnej, a także stopniem upowszechnienia partnerskiego modelu rodziny nuklearnej, gdzie opiekę nad dzieckiem sprawuje także ojciec. W Finlandii szczególnie wszechstronnie rozwinięto system instytucjonalnej opieki nad małym dzieckiem. Wszystkie dzieci poniżej wieku szkolnego mają prawo do opieki gminnej w odpowiednich placówkach. Rodziny o niskich dochodach są zwolnione z opłat za korzystanie z ich usług, a pozostałe są objęte systemem ulg, które przysługują w zależności od wielkości rodziny i uzyskiwanych dochodów. W 2005 r. z opieki gminnej skorzystało 23\% dzieci poniżej trzeciego roku życia i 62\% w wieku od trzech do pięciu lat. Rodzinom korzystającym z prywatnej opieki nad dzieckiem i zaakceptowanej przez władze gminne przysługuje specjalny zasiłek pieniężny. Rozwinięto w tym kraju sprawnie funkcjonujący system edukacji przedszkolnej: 96\% dzieci w wieku sześciu lat było objętych tą formą opieki w 2003 r. Ponadto, rodzice mają możliwość - w uzgodnieniu z pracodawcą - wykonywania pracy w zmniejszonym wymiarze 30 godzin tygodniowo do momentu rozpoczęcia przez dziecko drugiego roku nauki ${ }^{5}$.

\section{Praca zawodowa kobiet $\mathrm{w}$ projektach polityki ro- dzinnej}

Proponowane rozwiązania w zakresie polityki społecznej wobec rodziny w krajach Europy akcentują potrzebę

Por. T. Piensoho, E.M. Ojala, K. Mattila, M. Aaito-Kallio, M. Kansala, Godzenie życia zawodowego z rodzinnym. Dobre praktyki z Finlandii, Polski i Hiszpanii, Wydawnictwo Wyższej Szkoły Ekonomicznej w Białymstoku, Białystok 2007, s. 56, 61; Równowaga praca-życie. Studium porównawcze, Finlandia, Polska, Hiszpania, red. C. Sadowska-Snarska, Wydawnictwo Wyższej Szkoły Ekonomicznej w Białymstoku, Białystok, s. 46. 
utrzymania, a nawet podwyższania aktywności zawodowej kobiet ze względu na demograficzne starzenie się społeczeństw i wynikające stąd deficyty zasobów pracy. Przykładem takiego podejścia są scenariusze polityki rodzinnej do 2030 roku zawarte w opracowaniu The DIALOG Delphi Study ${ }^{6}$ Zalecane działania podkreślają m.in. znaczenie rozwiązań umożliwiających godzenie pracy zawodowej i obowiązków rodzinnych zarówno przez kobiety, jak i mężczyzn. Osiąganie tego celu jest możliwe dzięki zwiększaniu zatrudnienia w niepełnym wymiarze i elastycznych formach czasu pracy, a także rozwijaniu telepracy. Ponadto zaleca się doskonalenie systemu urlopów rodzicielskich, rozwój sieci żłobków i przedszkoli, wydłużanie czasu przebywania dzieci w szkole oraz na zajęciach w placówkach pozaszkolnych. Zmiana społecznych ról kobiet i mężczyzn powinna zmierzać do większego udziału mężczyzn w pracach domowych i ojców w opiece nad dziećmi, co pozwoli wyrównywać szanse kobiet na rynku pracy i osiąganie pozycji zawodowych, społecznych i politycznych zgodnych z ich aspiracjami. Formułowana jest nawet hipoteza, że kluczowym czynnikiem umożliwiającym obecnie realizację planów prokreacyjnych młodych pokolen jest tworzenie takich warunków aktywności zawodowej rodziców wychowujących małe dzieci, które pozwoliłyby pogodzić obowiązki wobec rodziny i pracodawcy ${ }^{7}$.

Podobne podejście prezentuje również Komisja Europejska, która w oficjalnym dokumencie z 2006 roku zaleca m.in. wspomaganie rodziców w okresie kształcenia

6 Por. R. Palomba, P. Dell Anno, 2030: Another Europe?, w: People, Population Change and Policies, red. Ch. Höhn, D. Avramov, I. Kotowska [Lessons from the Population Policy Acceptance Study, vol. 2: Demographic Knowledge - Gender - Ageing], Springer 2008, s. 93-108; S. Schmid, Looking into visions - methods and results of A Delphi Study on demographic development in 15 European countries, "Studia Demograficzne" No 2/148, PAN, KND, Warszawa 2005, s. 86-99.

7 Por. D. Avramov, R. Cliquet, The Need to Adapt and Reform Social Policy: Setting the Stage for Effective Population-friendly Policies, w: People, Population Change and Policies, dz. cyt., s. 286. 
dzieci w systemie edukacji, rozwój instytucjonalnych form opieki nad dziećmi, tworzenie warunków równych szans dla mężczyzn i kobiet na rynku pracy, rozwijanie elastycznych form pracy, ułatwienie dostępu do mieszkań młodym małżeństwom, przeciwdziałanie ubóstwu rodzin z dziećmi ${ }^{8}$. Projektowanie rozwiązań polityki rodzinnej w danym państwie wymaga uwzględnienia opinii społecznej na ten temat przede wszystkim ze względu na uwarunkowania kulturowe, normy i doświadczenia praktyczne, osiągnięty poziom rozwoju gospodarczego i ukształtowany stosunek do zadań państwa w tym zakresie. Dowiodły tego również badania $w$ ramach projektu „Dialog"9. Mimo istniejących różnic w pojmowaniu zadań i instrumentów polityki rodzinnej między społeczeństwami, urlop rodzicielski, który sprzyja realizacji postulatu równości mężczyzn i kobiet na rynku pracy, znalazł powszechne poparcie w populacji osób w wieku 20-49 lat $\mathrm{w}$ różnych krajach Europy. Zdaniem tej grupy osób, urlop rodzicielski dla matki i ojca powinien trwać łącznie 2-3 lata.

\section{Zakończenie}

Praca jest atrybutem każdej osoby ludzkiej, a w wymiarze społecznym - podstawą rozwoju wszystkich sfer życia człowieka ${ }^{10}$. Tak więc, godzenie funkcji rodzicielskich z pracą wymaga tworzenia warunków dla dokonywania przez matkę i ojca możliwie swobodnego wyboru między aktywnością zawodową a pracą $w$ rodzinnym gospodarstwie domowym w okresie wychowywania małych dzieci. Wydaje się, że partnerski model rodziny,

Por. Komisja Wspólnot Europejskich, Demograficzna przyszłość Europy przekształcić wyzwania w nowe możliwości, COM/2006/571, Bruksela, PL.

9 Por. A. Ochocki, Ludność świata - powinność i kapitał, Wydawnictwo Uniwersytetu Kardynała Stefana Wyszyńskiego, Warszawa 2010, s. 170-176.

10 Por. W. Zdaniewicz, Znaczenie Augustyńskiej filozofii pracy, Towarzystwo Naukowe Katolickiego Uniwersytetu Lubelskiego, „Roczniki Filozoficzne" 7(1959)2, s. 133. 
godziwe dochody gospodarstwa domowego, rozwinięta instytucjonalna opieka nad małymi dziećmi oraz pośrednie transfery finansowe związane $\mathrm{z}$ edukacją i ochroną zdrowia dzieci i młodzieży, mogą przywrócić naturalne proporcje pokoleń rodziców i dzieci. Symptomy takiego procesu odnotowano już w tych krajach Europy, gdzie konsekwentnie realizowana jest polityka rodzinna, tj. w Finlandii, Francji, Irlandii, Islandii, Norwegii i Szwecji.

Należy jednocześnie podkreślić, że człowiek jest samodzielna w istnieniu substancja natury rozumnej ${ }^{11}$, a jego atrybutem jest wolność dokonywania wyboru. Dlatego też, wyjaśnienia postaw i decyzji prokreacyjnych należy także poszukiwać w sferze sytemu wartości danego społeczeństwa czy - szerzej - wśród walorów danego kręgu kulturowego.

\section{The women work as a factor of the demographic change Summary}

The relation between parenthood and work is considered in the article and analysis covers five countries: Finland, Germany, Poland, the Czech Republic and Italy. The theoretical basis of the analysis is Gary S. Becker's thesis that there is the interaction between the quantity and quality of children at the household, for it implies that the demand for children is highly responsive to price and perhaps to income. It was also assumed that the prevailing tendency among married couples with small children is to optimize the use of parents' disposable time according to the total income including worth of work at the household. On the grounds of the analysis it was found that the vocational activity of mothers bringing up a small children is determined by both the level of well-being of the respective society and the solution within the family

11 Boecjusz, cyt. za: B. Gacka, Prezentacja personalizmu, <http://www.personalizm, pl/polrocznik/numer-1/prezentacja -personalizmu/>, (dostęp: 10.05.2006). 


\section{Część I}

Współczesna sytuacja demograficzna w Polsce

policy, but also by the popularity of the partnership-based model of nuclear family. The hypothesis could also be formulated that indirect public transfers to the family, that are associated with institutional care over children, stimulate vocational activity of mothers as well as fertility. 


\section{Małgorzata Pawlus}

Instytut Politologii UKSW

\section{Kobieta wielodzietna}

\section{Wstęp}

Feministyczna idea polityki umiejscowienia uznaje wielość różnic między kobietami, odrzuca uogólnienia i podkreśla znaczenie miejsca, z jakiego wygłasza się swoje racje. Niestety w polskim dyskursie feministycznym nie dostrzega się różnorodności kobiet i ich potrzeb. Znacznie częściej mamy do czynienia z zawłaszczeniem ruchu kobiecego przez jedną opcję pretendującą do wypowiadania się „w imieniu polskich kobiet” oraz reprezentowania ich interesów, co bywa określane problemem uniwersalizacji własnych doświadczeń przez feministki. Jedną $\mathrm{z}$ takich marginalizowanych grup są kobiety wielodzietne, których sytuacja społeczna jest niedostatecznie zbadana i opisana ${ }^{1}$. Niniejszy artykuł jest próbą charakterystyki kobiet wielodzietnych zarówno w odniesieniu do danych statystycznych (wyniki spisów powszechnych, dzietność kobiet), jak i socjologicznych analiz modeli macierzyństwa.

\section{Wielodzietność - charakterystyka demograficzno- społeczna}

Rodzina wielodzietna to rodzina mająca liczne potomstwo. Do drugiej wojny światowej za taką uchodziła rodzina z pięciorgiem dzieci i więcej, w pierwszych po-

\footnotetext{
$1 \quad$ W jednej z ostatnich naukowych publikacji poświęconych macierzyństwu: Pożegnanie z Matka Polką? Dyskursy, praktyki i reprezentacje macierzyństwa we współczesnej Polsce, red. R. Hryciuk, E. Korolczuk, Warszawa 2012, nie tylko nie uwzględniono zagadnienia matek wielodzietnych, ale również nie dostrzeżono tego braku w zakreślonych ramach analizy.
} 
wojennych dekadach - czworgiem i więcej, a od lat 70. kryterium wielodzietności jest posiadanie przynajmniej trójki dzieci². Odwołując się do statystyk, można stwierdzić, iż ta forma rodziny już dawno przestała być normą w życiu społeczeństwa polskiego, a wręcz jest zjawiskiem wygasającym. Zdaniem P. Szukalskiego, zmiana znaczenia samego terminu „wielodzietność" odzwierciedla zmniejszanie się gotowości do rodzenia dzieci wysokiej kolejności. W okresie powojennym odsetek dzieci czwartych i dalszych wynosił $20 \%$, dziś jest to jedynie ok. $5 \%$. Wyż demograficzny początku lat 80 . był w znacznej mierze rezultatem przychodzenia na świat kolejnych dzieci w rodzinach o dłuższym stażu. Jednak od lat 90. liczba urodzeń wysokich kolejności zmniejszała się corocznie ${ }^{4}$. W latach 2010-2012 nastąpiło wyhamowanie trendu spadku odsetka urodzeń trzeciej kolejności, przy równoczesnym dalszym spadku odsetka urodzeń czwartych, piątych i dalszych. W 2013 r. urodzenia pierwsze stanowiły $48,6 \%$, drugie $36,4 \%$, trzecie $10,4 \%$, czwarte $2,8 \%$, piąte i wyższej kolejności 1,8\% .

W świetle wyników NSP 2011, wśród 4640 tys. matek w wieku 16-49 lat, kobiety wielodzietne stanowiły 19,3\% (w tym 13,3\% z trójką dzieci i 6\% z czwórką i więcej). Wielodzietnością częściej cechowały się mieszkanki wsi - po-

2 Zdaniem D. Graniewskiej, o przyjęciu tego kryterium przesądzały względy socjalne - narodziny trzeciego dziecka często oznaczały znaczne pogorszenie sytuacji dochodowej rodziny. Por. Rodziny wielodzietne w Polsce. Teraźniejszość i przyszłość, red. B. Balcerzak-Paradowska, Warszawa 1997, s. 9.

3 Por. P. Szukalski, Wielodzietność we wspótczesnej Polsce, „Demografia i Gerontologia Społeczna - Biuletyn Informacyjny" (2012), $\mathrm{nr} \quad 4, \quad<$ http://repozytorium.uni.lodz.pl:8080/xmlui/bitstream/handle/11089/3514/2012-4\%20Wielodzietno\%C5\%9B\%C4\%87\%20we\%20 wsp\%C3\%B3\%C5\%82czesnej\%20Polsce.pdf?sequence=1>, (dostęp: 21.12.2014).

4 Por. Raport RRL, Sytuacja demograficzna Polski, Warszawa 2013, s. 102.

5 Dla porównania w 1989 r. urodzenia trzecie stanowiły ok. 17\%, czwarte 6,7\%, piąte i wyższe 5,1\%. Por. GUS, Urodzenia żywe wedtug kolejności urodzenia dziecka u matki w latach 1960-2013, <http://stat.gov.pl/download/gfx/portalinformacyjny/pl/defaultaktualnosci/5468/16/1/1/tablica_6. xls>, (dostęp: 21.11.2014). 
nad $17 \%$ z nich posiadało troje dzieci, a ponad $9 \%$ czworo i więcej. W miastach ich udziały wynosiły odpowiednio ponad $10,5 \%$ oraz $3,6 \%$ (tabela 1 ).

Tabela 1. Kobiety w wieku 16-49 lat, które rodziły dzieci według liczby żywo urodzonych dzieci i miejsca zamieszkania w 2011 roku

\begin{tabular}{|c|c|c|c|c|c|}
\hline \multirow{2}{*}{$\begin{array}{c}\text { Wy- } \\
\text { szcze- } \\
\text { gólnie- } \\
\text { nie }\end{array}$} & \multicolumn{4}{|c|}{ Kobiety według liczby żywo urodzonych dzieci } \\
\cline { 2 - 6 } & Ogółem & 1 dziecko & 2 dzieci & 3 dzieci & $\begin{array}{c}4 \\
\text { i więcej } \\
\text { dzieci }\end{array}$ \\
\cline { 2 - 6 } & w tys. & W odsetkach (struktura pozioma) \\
\hline Ogółem & 4640,0 & 37,0 & 41,3 & 13,3 & 6,0 \\
\hline Miasta & 2752,3 & 42,2 & 41,3 & 10,5 & 3,6 \\
\hline Wieś & 1887,7 & 29,5 & 41,2 & 17,4 & 9,4 \\
\hline
\end{tabular}

Źródło: GUS, Gospodarstwa domowe i rodziny. Charakterystyka demograficznaNSP 2011, Warszawa 2014, s. 59.

O zmniejszającej się skłonności kobiet do posiadania licznej rodziny świadczy również to, iż statystycznie w wyższych grupach wieku jest większy odsetek matek posiadających troje i więcej dzieci (tabela 2). Najwięcej wielodzietnych jest w grupie wiekowej 45-49 lat (1/3 matek) i niewiele mniej w grupie 40-44 (ok. 28\%) oraz dla wieku 35-39 lat niecałe 20\%. Wśród młodszych kobiet wielodzietność stanowi niewielki procent (30-34 lat - 10,8\%; $25-29-6,6 \% ; 20-24-2,3 \%)$. 


\section{Część I}

Współczesna sytuacja demograficzna w Polsce

Tabela 2. Kobiety w wieku 16-49 lat, które rodziły dzieci, według liczby żywo urodzonych dzieci i grup wieku w 2011 roku.

\begin{tabular}{|c|c|c|c|c|c|}
\hline \multirow{2}{*}{$\begin{array}{c}\text { Grupy } \\
\text { wieku }\end{array}$} & \multirow{4}{*}{ Kobiety według liczby żywo urodzonych dzieci } \\
\cline { 2 - 6 } & Ogół & 1 dziecko & 2 dzieci & 3 dzieci & $\begin{array}{c}4 \\
\text { i więcej } \\
\text { dzieci }\end{array}$ \\
\cline { 2 - 6 } & w tys. & W odsetkach (struktura pozioma) \\
\hline Ogółem & 4640,0 & 37,0 & 41,3 & 13,3 & 6,0 \\
\hline $\begin{array}{c}16-19 \\
\text { lat }\end{array}$ & 21,0 & 87,6 & 6,0 & 0,8 & 0,3 \\
\hline $20-24$ & 206,3 & 78,5 & 16,7 & 2,0 & 0,3 \\
\hline $25-29$ & 634,3 & 64,2 & 28,1 & 4,5 & 1,1 \\
\hline $30-34$ & 955,8 & 44,7 & 42,2 & 8,5 & 2,3 \\
\hline $35-39$ & 988,4 & 30,8 & 47,4 & 14,0 & 5,3 \\
\hline $40-44$ & 891,3 & 23,7 & 45,9 & 18,7 & 9,2 \\
\hline $45-49$ & 942,7 & 19,8 & 44,6 & 21,1 & 11,9 \\
\hline lat & & & & & \\
\hline
\end{tabular}

Źródło: GUS, Gospodarstwa domowe i rodziny. Charakterystyka demograficzna NSP 2011, Warszawa 2014, s. 60.

Należałoby również wziąć pod uwagę utrzymujący się trend odraczania w czasie decyzji o urodzeniu dziecka - w 2013 przeciętny wiek kobiet rodzących to 29 lat, a średni wiek urodzenia pierwszego dziecka 27 lat. Jedną z przyczyn odkładania zarówno zawierania małżeństw, jak i rodzicielstwa jest wydłużony okres kształcenia. Wzrost aspiracji edukacyjnych wśród kobiet ma swoje 
odzwierciedlenie w strukturze urodzeń - od 2009 r. najwyższy odsetek stanowią urodzenia wśród matek z wykształceniem wyższym . W 2012 r. było to ponad 45\%, co oznacza prawie 7-krotny wzrost w stosunku do lat $90^{6}$.

Analizując poziom wykształcenia matek w wieku 16-49 lat, zauważa się istotne różnice (tabela 3). Kobiety z wykształceniem wyższym mają najczęściej jedno lub dwoje dzieci (odpowiednio 48,9\% i 40,3\%) i tylko nieliczne $(8,5 \%)$ decydują się na dużą rodzinę (w tym troje $7,1 \%$, a czworo i więcej 1,4\%). Kobiety o najniższych poziomach wykształcenia zdecydowanie częściej posiadały większą liczbę dzieci. Prawie 40\% kobiet o wykształceniu gimnazjalnym i podstawowym oraz bez wykształcenia zadeklarowało, że urodziło troje i więcej dzieci. Wśród kobiet z wykształceniem zasadniczym zawodowym było ok. $30 \%$ wielodzietnych.

Tabela 3. Kobiety w wieku 16-49 lat, które rodziły dzieci, według liczby żywo urodzonych dzieci i poziomu wykształcenia w 2011 roku

\begin{tabular}{|c|c|c|c|c|c|}
\hline \multirow{2}{*}{$\begin{array}{c}\text { Grupy } \\
\text { wieku }\end{array}$} & Kobiety według liczby żywo urodzonych dzieci \\
\cline { 2 - 6 } & Ogółem & 1 dziecko & 2 dzieci & 3 dzieci & $\begin{array}{c}4 \\
\text { i więcej } \\
\text { dzieci }\end{array}$ \\
\cline { 2 - 6 } & w tys. & W odsetkach (struktura pozioma) \\
\hline Ogółem & 4640,0 & 37,0 & 41,3 & 13,3 & 6,0 \\
\hline Wyższe & 1310,4 & 48,9 & 40,3 & 7,1 & 1,4 \\
\hline $\begin{array}{c}\text { Średnie } \\
\text { zawodowe }\end{array}$ & 1190,1 & 36,4 & 44,3 & 13,0 & 4,5 \\
\hline
\end{tabular}

6 Por. GUS, Podstawowe informacje o rozwoju demograficznym Polski do 2013 roku, Warszawa 2014, s. 5. 
Współczesna sytuacja demograficzna w Polsce

\begin{tabular}{|c|c|c|c|c|c|}
\hline $\begin{array}{c}\text { Średnie } \\
\text { ogólno- } \\
\text { kształcące }\end{array}$ & 648,1 & 42,0 & 40,2 & 11,2 & 3,5 \\
\hline $\begin{array}{c}\text { Zasadnicze } \\
\text { zawodowe }\end{array}$ & 1121,8 & 24,8 & 42,7 & 19,7 & 10,5 \\
\hline $\begin{array}{c}\text { Podstawo- } \\
\text { we i gim- } \\
\text { nazjalne }\end{array}$ & 365,4 & 25,2 & 32,8 & 20,7 & 18,5 \\
\hline $\begin{array}{c}\text { Podstawo- } \\
\text { we nie- } \\
\text { ukończone } \\
\text { i bez wy- } \\
\text { kształcenia } \\
\text { szkolnego }\end{array}$ & 4,1 & 27,6 & 27,7 & 20,3 & 19,0 \\
\hline
\end{tabular}

Źródło: GUS, Gospodarstwa domowe i rodziny. Charakterystyka demograficzna NSP 2011, Warszawa 2014, s. 60.

Wykształcenie bywa traktowane jako jeden z determinantów wielodzietności, czego wyrazem może być ogólna prawidłowość: im niższe wykształcenie, tym wielodzietność jest zjawiskiem częstszym ${ }^{7}$. Ten niższy od przeciętnego poziom wykształcenia kobiet wielodzietnych wynika z faktu, iż są one z reguły starsze niż ogół matek (należą do roczników, które miały niższe możliwości kontynuowania edukacji) oraz częściej zamieszkują obszary wiejskie, gdzie ludność generalnie jest gorzej wykształcona ${ }^{8}$. Jednakże już w badaniach rodzin wielodzietnych z lat 90 . wskazywano wyraźny trend ograniczania wielodzietności przez generację młodych matek zamieszkujących tereny wiejskie (szybki spadek liczby urodzeń wyższej kolejności), a zarazem wzrost urodzeń szóstych i dalszych u matek z wyższym wykształceniem, co wstępnie zostało określone jako zjawisko „wielodzietności świadomie realizowanej", wynikającej z uznawanego światopoglądu

Rodziny wielodzietne w Polsce, dz. cyt., s. 14.

Por. P. Szukalski, dz. cyt. 
i wychowawczo-moralnych wartości przypisywanych rodzinie wielodzietnej ${ }^{9}$. W ostatnich latach również odnotowano niewielki wzrost odsetka urodzeń trzecich oraz czwartych i dalszych wśród kobiet z wyższym wykształceniem: od 5,71\% i 1,33\% w 2006 do 6,86 i 1,43\% w 2012 r. Przy czym, więcej urodzeń żywych wyższej kolejności w 2012 r. było na wsi: odpowiednio 8,05\% urodzeń trzecich i 1,74\% czwartych i dalszych ${ }^{10}$.

Nie zmienia to jednak faktu, iż rodzin wielodzietnych ubywa. Od poprzedniego spisu powszechnego w 2002 r. liczba rodzin z co najmniej trójką dzieci na utrzymaniu zmniejszyła się o ok. 39\% (1024 tys. w 2002 r. i 626,8 tys. w 2011 r.). Zdaniem francuskiego ekonomisty J. D. Lecaillona, w przeszłości to istnienie rodzin wielodzietnych zapewniało równowagę demograficzna, bo chociaż były mniejszościa, to pochodziła $\mathrm{z}$ nich duża liczba dzieci ${ }^{11}$. Tym samym zanik rodzin wielodzietnych można łączyć z pogłębiającym się kryzysem ludnościowym. Pojawia się wątpliwość, czy ten trend jest odzwierciedleniem zmiany preferencji kobiet odnośnie do modelu rodziny (kobiety chcą mieć mniej dzieci), czy też ograniczanie dzietności jest uwarunkowane czynnikami zewnętrznymi (kobiety mają mniej dzieci niżby chciały)?

\section{Tradycyjny model macierzyństwa}

Postrzeganie kobiet wielodzietnych jest niejednoznaczne. Z jednej strony, występuje stereotypizacja mająca częściowe odzwierciedlenie w danych statystycznych, gdzie wielodzietność jest cechą środowiskową kojarzoną z niezaradnością i brakiem wykształcenia. Z drugiej, w kontekście niskiego poziomu dzietności, kobieta, która decyduje się na dużą rodzinę, jest etykietowana jako Matka-Polka.

Por. Rodziny wielodzietne w Polsce, dz. cyt., s. 14.

Por. Raport RRL, dz. cyt., s. 110-112.

11 Por. J.D. Lecaillon, Rodzina źródłem dobrobytu, Warszawa 2004, s. 20, 63. 
Sięgając do historii Polski okresu zaborów, MatkaPolka jawi się jako symbol łączący wartości związane ze sferą prywatną (matka) z działalnością obywatelską i patriotyczną (Polka) oraz wskazujący na dom i rodzinę jako pole aktywności kobiecej. Kobiety, rodząc i wychowując dzieci, w polskiej tradycji aktywnie włączały się w walkę o niepodległość. W symbolu Matki-Polki tożsamość kobiety zostaje podporządkowana wartościom narodowo-religijnym. Najważniejszym aspektem kulturowego wzorca kobiety polskiej jest heroizm i poświęcenie wyrażające się w zdolności sprostania najtrudniejszym wymaganiom stawianym przez rzeczywistość społeczną ${ }^{12}$.

Symbol Matki-Polki na nowo powrócił w okresie PRL-u, z czasem zmieniając swoje znaczenie. W pierwszych latach powojennych prezydent Bolesław Bierut odznaczał Krzyżem Zasługi matki, które wychowały dziesięcioro i więcej dzieci. Następująca w kolejnych latach zmiana postrzegania wielodzietności wyraźnie wiązała się z nowym ukierunkowaniem polityki ludnościowej i preferowaniem modelu rodziny 2+2. Matka-Polka w PRL-u, to kobieta obarczona wychowaniem dzieci i pracą zawodowa, codziennie walcząca o utrzymanie rodziny w warunkach gospodarki niedoboru, inaczej „matka gastronomiczna”, godzinami wystająca w kolejkach, dźwigająca siatki z zakupami, skoncentrowana na tym, żeby rodzina miała co jeść. Zdaniem socjologów, w ówczesnych polskich rodzinach funkcjonował tzw. menadżerski matriarchat, który opierał się na silnej roli kobiecej w domu i był podstawowym źródłem ich życiowej satysfak$\mathrm{cji}^{13}$. Jak zauważa A. Titkow: figura Matki-Polki petniła funkcje swoistego kamuflażu dla rozszerzenia zakresu tradycyjnych ról kobiecych bez naruszania obowiazujacego kulturowego kontraktu ptci ${ }^{14}$, a jego synonimem jest współczesne pojęcie superkobiety.

12 Por. A. Titkow, Kobiety pod presją? Proces kształtowania się tożsamości, w: Co to znaczy być kobieta w Polsce, red. A. Titkow, H. Domański, Warszawa 1995, s. 14.

13 Por. tamże, s. 31-32.

14 A. Titkow, Figura Matki Polki. Próba demitologizacji, w: Pożegnanie z Matka Polką?, dz. cyt., s. 28. 
Według środowisk feministycznych, od lat 90. mamy do czynienia z próbą wskrzeszania stereotypu Matki-Polki w środowiskach prawicowych i wśród przedstawicieli Kościoła katolickiego ${ }^{15}$. Matka-Polka powinna być oddana całkowicie rodzinie, a jej życie ma spełniać się w rodzeniu i wychowywaniu dzieci. Dla polskich feministek polityka prorodzinna afirmująca macierzyństwo i model rodziny wielodzietnej poprzez swój pronatalistyczny charakter oznacza wymuszanie na kobietach rodzenia kolejnych dzieci, a Matka-Polka staje się wzorcem ofiarnej, biernej kobiety, której pozycja społeczna została zredukowana do stereotypowych ról w rodzinie. W roku 1998, w jednej z debat o polityce państwa na rzecz rodzin, posłanka AWS Urszula Wachowicz podniosła problem kreowania przez media i kulturę wzorca kobiecości jako modelu indywidualnej kariery kobiety wyzwolonej od swego naturalnego powołania "matki, wiernej żony". Z kolei, posłanka SLD Alicja Murynowicz zarzuciła stronie rządowej uprzedmiotowianie kobiet, traktowanie ich wyłącznie jako współreproduktorki dzieci, promowanie wzorca Matki-Polki, która siedzi w kuchni, dba o dzieci, głaszcze po główkach, gotuje obiadki ${ }^{16}$.

Krytyka zdeterminowanych płciowo ról kobiecych ma długą tradycję. Już w 1949 roku Simone de Beauvoir w swojej książce Druga płeć podkreślała, iż to właśnie role społeczne żony i matki są głównym mechanizmem podporządkowywania kobiety i utrwalenia jej statusu jako uprzedmiotowionej Innej. Drogą wyzwolenia i upodmiotowienia jest proces samookreślenia, kreowania własnej tożsamości w drodze świadomego działania, w szczególności poprzez opanowanie funkcji rozrodczych

15 Por. J. Kantola, Polityka równości ptci w Unii Europejskiej, Warszawa 2012, s. 23. Teza o „nowej tradycjonalizacji” po 1989 r. jest od wielu lat powtarzana w dyskursie feministycznym. Jednakże adekwatniejszym określeniem ówczesnej sytuacji jest konflikt ideologiczny w kwestii nowego modelu polityki państwa na rzecz kobiet, w której jedną ze stron był sam ruch feministyczny.

16 Por. Sejm III kad., Stenogram 29. posiedzenia z dnia 22.09.1998. 
oraz pracę zawodową. Zainicjowana przez de Beauvoir feministyczna deprecjacja macierzyństwa jako totalnego obciążenia kobiety jest wciąż kontynuowana, chociaż w bardziej wysublimowanej formie: Nie chodzi o odrzucenie macierzyństwa jako wartości, ale o zrewidowanie związanych z nim stereotypów, odrzucenie mitu macierzyństwa i „wiecznego poświęcenia”"17.

Początkowo zwracano uwagę, iż fakt biologicznego zdeterminowania macierzyństwa nie jest racją uzasadniającą utrzymywania społeczno-kulturowej presji posiadania dzieci i stereotypowego postrzegania miejsca i roli kobiet. Polski ruch feministyczny już w latach 90. opowiedział się za prawem każdej kobiety do swobodnego wyboru modelu pełnienia tej roli osobistej, a także do rezygnacji z niej (prawo do aborcji), równocześnie postulując konieczność dowartościowania zawodowej, społecznej i politycznej aktywności kobiet ${ }^{18}$. Obecnie, na skutek wpływu postmodernistycznie zorientowanego feminizmu, promowana jest koncepcja płci społeczno-kulturowej (gender), w świetle której kobiecość i męskość są społecznymi konstrukcjami, które podlegają zmianom ${ }^{19}$. Jednakże analizy genderowe, ignorując płeć biologiczną oraz biologiczne różnice, mogą prowadzić do zafałszowania rzeczywistego obrazu życia kobiet. Zdaniem B. Szackiej, we współczesnym dyskursie feministycznym dominuje jawny determinizm kulturowy, przy równoczesnym ignorowaniu dorobku współczesnej biologii i psychologii ewolucyjnej dotyczącego płci i reprodukcji człowieka ${ }^{20}$.

Proces indywidualizacji oraz wzrost zapotrzebowania na wolność i niezależność łączą się ze zmianą wartościowania macierzyństwa, które cieszy się coraz mniejszym

\footnotetext{
17 Por. M. Środa, Kobiety i władza, Warszawa 2009, s. 84-88.

18 Por. A. Matuchniak-Krasuska, Ruch feministyczny i kobiecy w Polsce. Interwencja socjologiczna 1994/1995, „Acta Universitatis Lodziensis, Folia Sociologica", nr 27, s. 128-129.

19 Por. A. Gromkowska-Melosik, Edukacja i (nie) równość społeczna kobiet. Studium dynamiki dostępu, Kraków 2011, s. 173.

20 Por B. Szacka, Gender i płeć, w: Gender w społeczeństwie polskim, red. K. Slany, J. Struzik, K. Wojnicka, Kraków 2011, s. 24.
} 
prestiżem społecznym i nie może stanowić źródła pełnej samorealizacji kobiety jako równoprawnej $\mathrm{z}$ mężczyzną jednostki ludzkiej²1. Odzwierciedleniem tego trendu może być europejska polityka wspierania równości kobiet i mężczyzn, w której szczególny nacisk kładzie się na zakwestionowanie i przezwyciężenie tradycyjnych stereotypów ról płciowych. W lansowanym wzorcu osobowym współczesnej młodej kobiety priorytetem jest dbałość o własny rozwój i awans zawodowy (inwestowanie w siebie). Młode kobiety kwestię małżeństwa i macierzyństwa odsuwają w czasie, a czasami z nich rezygnuja gdyż stanowi to barierę $w$ rozwoju kariery ${ }^{22}$. Ponieważ w społeczeństwach rozwiniętych praca zawodowa staje się źródłem spełnienia, a dochód decyduje o uznaniu społecznym i statusie, to zatrudnienie jest norma a kobiety, które nie chcą jej odpowiadać, są ignorowane zarówno $\mathrm{w}$ wymiarze instytucjonalnym (powiązanie prawa do emerytury z płatną pracą), jak i społeczno-kulturowym (dewaluacja roli gospodyni domowej oraz pracy matek wychowujących dzieci) ${ }^{23}$.

\section{Wielodzietność jako „nowy” model macierzyństwa}

W warunkach szybko zachodzących zmian społecznych wyłaniają się nowe kobiece wzorce, zróżnicowane i wielorakie: kobieta sukcesu, Matka-Polka wyzwolona, nowa matka ${ }^{24}$. M. Sikorska, badając proces przemiany wzorców życia rodzinnego w Polsce, opisuje współczesną matkę jako diametralnie różną od tradycyjnej Matki-Polki. Nowa matka nie musi być już doskonała i ma do wyboru wiele różnych wzorów macierzyństwa, a zarazem

21 Por. D. Duch-Krzystoszek, Kto rzadzi w rodzinie? Socjologiczna analiza relacji w matżeństwie, Warszawa 2007, s. 128-129.

22 Por. A. Maciarz, Macierzyństwo w kontekście zmian społecznych, Warszawa 2004, s. 19.

23 Por. J.D. Lecaillon, dz. cyt., s. 22-23.

24 Określenie „nowa matka” nawiązuje do książki M. Sikorskiej, Nowa matka, nowy ojciec, nowe dziecko. O nowym układzie sit w polskich rodzinach, Warszawa 2009.

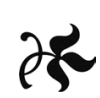


ten wzrost możliwości jest związany ze wzrostem ryzyka i niepewności młodej mamy ${ }^{25}$. W tym kontekście narzuca się pytanie, na ile takim wyborem i jednym ze społecznie akceptowanych wzorów macierzyństwa jest wielodzietność? Czy nadal powinna być etykietowana mianem tradycyjnego wzorca, czy też wpisuje się w nowy model macierzyństwa?

Kluczowymi wyznacznikami nowego modelu macierzyństwa jest poszanowanie wolności indywidualnego wyboru kobiety zarówno odnośnie do decyzji prokreacyjnych, jak i wobec pełnionych ról rodzinnych i zawodowych. W dyskursie feministycznym wolność wyboru jest utożsamiana $\mathrm{z}$ wolnością reprodukcyjna, uznaniem praw reprodukcyjnych, które powinny się wyrażać przede wszystkim w dostępności antykoncepcji i aborcji. Natomiast postulat prawa do macierzyństwa pojawia się wyłącznie w kontekście walki o in vitro. Wielodzietność postrzegana jest jako nieumiejętność, niemożność kontrolowania własnej płodności, a nie wyraz praw reprodukcyjnych do wolnego i odpowiedzialnego decydowania pary małżeńskiej o liczbie i czasie przychodzenia na świat ich dzieci. Potencjalna wolność wyboru posiadania dużej rodziny jest silnie ograniczona uwarunkowaniami ekonomicznymi i brakiem wymiernego wsparcia państwa. W świetle danych statystycznych, wzrost liczebności gospodarstwa domowego jest silnie powiązany z większym zagrożeniem ubóstwem i najwyższe wartości osiąga $\mathrm{w}$ rodzinach wielodzietnych $\mathrm{z}$ trojgiem bądź większą liczbą dzieci na utrzymaniu (wskaźnik w 2011 r. wyniósł $34,6 \%)^{26}$.

25 Por. tamże, s. 173-178.

26 Por. MPiPS, Krajowy Program Przeciwdziałania Ubóstwu i Wykluczeniu Społecznemu 2020. Nowy wymiar aktywnej integracji, Warszawa 2013, s. 9. Podobne wnioski można znaleźć w raporcie IBS: gospodarstwa wielodzietne sa znacznie bardziej zagrożone ubóstwem niż te, w których liczba dzieci na utrzymaniu nie przekracza dwojga - w analizowanej subpopulacji gospodarstw złożonych $z$ dorosłych w wieku tworzenia $i$ rozwijania rodziny, ryzyko ubóstwa w gospodarstwach $z$ jednym lub dwojgiem dzieci wyniosto w 2011 roku 10\%, a tych z większa licza dzieci - 29\%. Problem ubóstwa 
Drugi wyznacznik modelu nowego macierzyństwa dotyczy sposobu wypełniania ról macierzyńskich i ściśle jest związany ze standardem równości płci. Macierzyństwo nie tyle jest elementem tożsamości kobiety, co jedną z wielu funkcji. Jest to macierzyństwo, które nie zniewala i nie wyklucza z pełnienia innych ról społecznych czy zawodowych. Możliwość realizowania pozarodzinnych aspiracji matek jest silnie uwarunkowana istnieniem systemu wsparcia: w postaci męża, bliskiej rodziny, instytucji opiekuńczo-wychowawczych. Jednak ten model kobiety-matki realizującej się w rolach zawodowych i robiącej karierę zasadniczo dotyczy rodzin jedno-, dwudzietnych, w których kobieta nie jest przeciążona obowiązkami opiekuńczo-wychowawczymi.

Jak zatem wygląda sytuacja kobiet wielodzietnych? Na ile wielodzietność różnicuje nasz nowy model matki? Czy kobiety mogą mieć wszystko - karierę i macierzyństwo? Zjawisko zanikania rodzin wielodzietnych może być odzwierciedleniem istniejących ograniczeń: Jedyne czego nie można mieć jednocześnie, to gromadka dzieci w domu i dotrzymanie kroku w biurowym współzawodnictwie. Zmuszone dokonać wyboru, kobiety wybierają karierę lub karierę i ewentualnie posiadanie jednego dziecka ${ }^{27}$. Problem konfliktu pomiędzy zaangażowaniem kobiet w pracę zawodowa i życie rodzinne oraz heterogeniczność kobiecych wyborów w zakresie stylu życia jest podstawą do tworzenia socjologicznych klasyfikacji. C. Hakim, badając modele pracy zawodowej brytyjskich kobiet, wyróżniła trzy kategorie: skoncentrowane na ognisku domowym (home-centred), przystosowane (adapted), skoncentrowane na pracy (work-centred) ${ }^{28}$. Z kolei amerykański badacz N. Gilbert zaproponował typologię, w której podstawo-

gospodarstw wielodzietnych jest tym bardziej istotny, że należace do nich dzieci stanowia aż $25 \%$ wszystkich osób poniżej 16 roku życia. Por. Zatrudnienie w Polsce 2011. Ubóstwo a praca, red. M. Bukowski, I. Magda, Warszawa 2013, s. 81.

27 Por. P. J. Buchanan, Śmierć Zachodu, Wrocław 2005, s. 47.

28 Por. E. Badinter, Konflikt: kobieta i matka, Warszawa 2013, s. 21-22. 


\section{Część I}

Współczesna sytuacja demograficzna w Polsce

wym kryterium jest liczba posiadanych dzieci, a jej dwie skrajne kategorie to matki wielodzietne (określone jako tradycjonalistki) oraz kobiety bezdzietne (postmodernistki). Środkowe miejsce w tym modelu zajmują kobiety łączące wychowanie dzieci z praca zawodowa, czyli neotradycjonalistki (matki dwojga dzieci) i kobiety nowoczesne ${ }^{29}$. W świetle tych modeli, kobiety wielodzietne to skoncentrowane na ognisku domowym inaczej tradycjonalistki, które stawiają życie rodzinne i dzieci na pierwszym miejscu, w tym celu rezygnując $\mathrm{z}$ aktywności zawodowej.

Pojawia się pytanie: na ile powyższe klasyfikacje można odnieść do polskich realiów? Czy w kontekście istniejącej sytuacji gospodarczej, społecznej i politycznej, możemy mówić o różnorodności wyborów macierzyńskich i stylów życia? Czy kobiety mogą skoncentrować się na wychowaniu dzieci i prowadzeniu domu? W europejskiej polityce rynku pracy jednym z częściej stosowanych narzędzi ułatwiających kobietom łączenie obowiązków rodzinnych i zawodowych jest praca w niepełnym wymiarze czasu pracy - średnio 1/3 kobiet w krajach UE wybiera taką formę zatrudnienia, w Polsce zaledwie 11\% kobiet ${ }^{30}$. Czy w sytuacji wzrastającej niepewności zatrudnienia oraz niskich płac (płaca minimalna w Polsce w 2014 to 1680 zł brutto) możliwa jest czasowa rezygnacja kobiet $\mathrm{z}$ zatrudnienia?

Większa liczba dzieci wydłuża okres niezbędnej opieki nad nimi, zwiększa liczbę obowiązków domowych i w konsekwencji zmniejsza możliwość pracy matek poza domem. Co również oznacza, że rodzina wielodzietna dysponuje zazwyczaj jednym źródłem utrzymania i wraz z liczbą dzieci pogarsza się ich sytuacja materialna ${ }^{31}$. $\mathrm{W}$ badaniach rodzin wielodzietnych z lat 90 . wskazano

Por. tamże, s. 23-25.

30 Por. European Commission, Questions and Answers: What has the EU done for women? 50 years of EU action on Gender Equality for One Continent, $<$ http://europa.eu/rapid/press-release_MEMO-14-156_en.htm>, (dostęp: 22.12.2014).

31 Por. J.D. Lecaillon, dz. cyt., s. 15-16. 
na dominujący w nich model tradycyjnego podziału obowiązków rodzinnych, w którym mężczyzna jest odpowiedzialny za byt ekonomiczny, a kobieta sprawuje opiekę nad dziećmi i jest obciążona większością prac domowych. Czynnikami warunkującymi sytuację wewnątrzrodzinną było wykształcenie, miejsce zamieszkania oraz wiek małżonków ${ }^{32}$. Jednakże już na początku okresu transformacji ustrojowej w Polsce, na skutek presji rynku pracy i rosnących kosztów utrzymania, prawie $60 \%$ matek wielodzietnych pracowało zawodowo, coraz rzadziej decydując się na urlop wychowawczy (w 1991 r. 38,4\% dzieci z rodzin wielodzietnych było pod opieką matek przebywających na urlopie wychowawczym, a w 1994 r. już tylko 14,3\%) 3. $^{33}$. Przekształcenia w obrębie modelu rodziny były interpretowane $\mathrm{w}$ kategoriach indywidualnych strategii $\mathrm{w}$ nowych warunkach ekonomicznych, politycznych, społecznych ${ }^{34}$. Jak zauważa Szukalski, obecnie blisko 2/3 matek rodzących trzecie lub dalsze dziecko pozostaje aktywne zawodowo ${ }^{35}$.

Upowszechnienie pracy zawodowej kobiet bywa postrzegane jako jedna z przyczyn zaniku rodzin wielodzietnych - kobiety, realizując role zawodowe, nie odrzucają macierzyństwa, ale ograniczają liczbę dzieci. W klasycznym ujęciu relacji pomiędzy pracą zawodową a dzietnością funkcjonowały dwie normy rozrodczości: niższa dzietność matek pracujących zawodowo i wyższa wśród niepracujących ${ }^{36}$. W najnowszych badaniach wskazuje się, iż niska dzietność to efekt zarówno niedostosowania rozwiązań instytucjonalnych do pracy zawodowej kobiet (konflikt strukturalny), jak i skutek norm kulturowych ról społecznych kobiet i mężczyzn (konflikt kulturowy). W krajach, w których oba konflikty są słabsze,

Por. Rodziny wielodzietne w Polsce, dz. cyt., s. 72-73.

Por. tamże, s. 74.

34 Por. A. Giza-Poleszczuk, Rodzina i system społeczny, w: Wymiary życia społecznego. Polska na przełomie XX i XXI wieku, red. M. Marody, s. 314.

35 Por. P. Szukalski, dz. cyt.

36 Por. J.D. Lecaillon, dz. cyt. s. 49. 
wysoka aktywność zawodowa kobiet współwystępuje ze stosunkowo wysoką dzietnością ${ }^{37}$. Kariery zawodowe kobiet są konsekwencją wzrostu poziomu ich wykształcenia, co wiąże się ze zmianą aspiracji i wartościowania macierzyństwa. Isabelle Robert-Bobee stwierdza: Kobiety o najwyższych kwalifikacjach moga oczekiwać uznania społecznego dzięki pracy, która wykonuja, tymczasem kobiety o najniższych kwalifikacjach zyskuja to uznanie przede wszystkim dzięki statusowi matki ${ }^{38}$.

Zdaniem Philipova ${ }^{39}$, nie ma jednego doskonałego modelu podziału pracy $\mathrm{w}$ rodzinie, który rozwiązałby problem niskiej dzietności. Zarówno tzw. klasyczny model rodziny z mężczyzną jako jedynym żywicielem (male breadwinner model), jak i model z obojgiem pracujących rodziców, nazywany również modelem z równoległymi karierami zawodowymi rodziców (dual-earner/dualcarer model), zawiera elementy pozytywne i negatywne. Dla kobiet wielodzietnych częstszym rozwiązaniem jest pierwszy z modeli oznaczający czasową rezygnację lub niepodejmowanie pracy zawodowej. Małżonkowie dzielą się pracą - mężczyzna zarabia, kobieta specjalizuje się w pracach domowych oraz zapewnia dzieciom opiekę i wychowanie wyższej jakości. Słabością tradycyjnego podziału ról jest ograniczenie kobiecej autonomii i możliwości realizowania się przez pracę zawodowa, zawężenie społecznych kontaktów oraz niższy przychód rodziny. Z kolei, w modelu z obojgiem pracujących rodziców następuje odwrócenie pozytywnych i negatywnych cech modelu klasycznego. Praca zawodowa matek oznacza zwiększenie poziomu kobiecej autonomii i poczucia sa-

37 Por. Niska dzietność w Polsce w kontekście percepcji Polaków. Diagnoza społeczna 2013, red. I. Kotowska, Warszawa 2014, s. 43-44, <http://www.diagnoza.com/pliki/raporty_tematyczne/Niska_dzietnosc_w_Polsce.pdf>, (dostęp: 8.04.2014).

38 Cyt. za E. Badinter, dz. cyt., s. 173.

39 Por. D. Philipov, Should governments in Europe be more aggressive in pushing for gender equality to raise fertility? The first "NO", "Demographic Research" 2011, volume 24, s. 201-216, <http://www.demographic-research.org/Volumes/Vol24/8/>, (dostęp: 31.10.2014). 
morealizacji, umożliwia poszerzenie społecznych kontaktów oraz zwiększa dochód rodziny. Negatywnym aspektem jest, iż brak podziału pracy skutkuje niższą jakością prac domowych, mniejszą ilością czasu przeznaczanego na opiekę i wychowanie dzieci oraz wzrostem tzw. kosztów alternatywnych posiadania dzieci. Philipov wskazuje jeszcze tzw. model pośredni, gdy aktywność zawodowa obojga rodziców oznacza pracę kobiet na część etatu, a zmniejszenie wymiaru czasu pracy ułatwia wypełnianie ról macierzyńskich ${ }^{40}$. Ten model również może być rozwiązaniem dla kobiet wielodzietnych. Paradoksalnie, w sytuacji pracy obojga małżonków, a zarazem licznych obowiązków domowych i wychowawczych, bardziej egalitarny podział prac i uelastycznianie pełnionych ról staje się koniecznością.

Warto jeszcze zwrócić uwagę na inny, nie mniej ważny, aspekt łączenia aspiracji zawodowych kobiet z życiem rodzinnym. Współczesne kobiety mogą mieć wszystko - pracę i dzieci, ale pogłębiający się konflikt ról macierzyńskich i zawodowych postrzegany jest jako kwadratura koła. Problem łączenia pracy i wychowania dzieci szczególnie ujawnia się w sytuacji ponoszenia wyższych kosztów w jednej z tych sfer i może to dotyczyć zarówno tzw. kobiet sukcesu, jak i matek wielodzietnych, a ekstremalnym przypadkiem będzie model kariery zawodowej kobiety wielodzietnej. Zwielokrotnione trudności w godzeniu macierzyństwa z pracą zawodową wynikają z ciągłego obciążenia nadmiarem obowiązków domowych oraz pracą emocjonalną nad relacjami rodzinnymi w sytuacji chronicznego braku czasu. We współczesny nowy model macierzyństwa mocno jest wpisany aspekt emocjonalny. Z jednej strony, kobiety doświadczają presji, by robić karierę, a z drugiej, mają poczucie winy, że nie pracują. Przeżywają rozterki w sytuacji pozostania $\mathrm{w}$ domu z dziećmi, ale również w sytuacji podjęcia pracy ${ }^{41}$.

\footnotetext{
$40 \quad$ Por. tamże, s. 208.

41 Por. H. Bradley, Płeć, Warszawa 2008, s. 138-139.
} 


\section{Zakończenie}

Kobieta wielodzietna, to matka przynajmniej trójki dzieci, a sama zmiana terminu „wielodzietność" odzwierciedla zmniejszanie się skłonności kobiet do posiadania licznej rodziny. W świetle wyników NSP 2011, wielodzietna jest prawie co piąta kobieta $\mathrm{w}$ wieku reprodukcyjnym, w tym $2 / 3$ ma troje dzieci, a tylko $1 / 3$ czworo $i$ więcej. Są to prawie dwukrotnie częściej mieszkanki wsi i ich odsetek jest większy $w$ wyższych grupach wieku (40-44 i 45-49). Stanowią przynajmniej 1/4 matek w tych grupach wiekowych i często zakończyły już okres prokreacyjny (zwłaszcza po 45. roku, cząstkowy współczynnik płodności 0,3 promila). Statystycznie, kobiety wielodzietne są gorzej wykształcone, tylko $8,5 \%$ matek ma wyższe wykształcenie i wychowuje przynajmniej troje dzieci (w tym tylko 1,4\% czworo i więcej). Kobiety z wykształceniem wyższym mają najczęściej jedno lub dwoje dzieci (odpowiednio 48,9\% i 40,3\%) i tylko nieliczne mają więcej potomstwa (w tym troje $7,1 \%$, a czworo i więcej $1,4 \%$ ).

Niewątpliwie, jest coraz mniej kobiet, które decydują się na urodzenie dzieci wyższej kolejności, a przyczyny tego są złożone i wymagają pogłębionych badań. Od poprzedniego spisu powszechnego w $2002 \mathrm{r}$. liczba rodzin z co najmniej trójką dzieci na utrzymaniu zmniejszyła się o ok. 39\% (1024 tys. w 2002 r. i 626,8 tys. w 2011 r.). W sytuacji, gdy wzrasta odsetek kobiet bezdzietnych oraz tych, które posiadają tylko jedno dziecko, bez kobiet wielodzietnych nie ma możliwości odbudowania prostej zastępowalności pokoleń. Dlatego też istnieje konieczność rozpoznania potrzeb tej grupy i wykreowania adekwatnej polityki.

W zakończeniu chciałabym się odwołać do dwuwymiarowej koncepcji sprawiedliwości społecznej Nancy Fraser, która dotyczy potrzeby zintegrowania polityki 
redystrybucji z polityką uznania ${ }^{42}$. Kobiety wielodzietne doświadczają strukturalnej niesprawiedliwości mającej źródło w sferze ekonomicznej (m.in. kwestia emerytur, obciążenia podatkowe), a środkiem zaradczym jest redystrybucja, czyli zmiana dystrybucji korzyści i obciążeń względem rodzin wielodzietnych. Z kolei, brak uznania dla wielodzietności, czyli niesprawiedliwości kulturowe, mają źródło w społecznym porządku statusu, w zinstytucjonalizowanych wzorcach wartości (wielodzietność jako patologia). Bez polityki rodzinnej, która będzie łączyła skuteczne działania redystrybucyjne z klimatem przyjaznym rodzinie, $\mathbf{z n}$. społecznym uznaniem dla tych, którzy chcą realizować model dużej rodziny, kobieta wielodzietna nadal będzie skazana na stereotyp heroicznej Matki-Polki, zamiast być po prostu kobietą spełnioną w swoim macierzyństwie i preferowanym stylu życia.

$\overline{42}$ Por. N. Fraser, A. Honneth, Redystrybucja czy uznanie. Debata politycznofilozoficzna, Wrocław 2005. 



\section{Magdalena Witkowska}

Mgr profilaktyki społecznej i resocjalizacji

\section{Przekonania i postawy prokreacyjne u osób świadomie wybierających wielodzietność}

\section{Wstęp}

Od kilkunastu lat rodzi się w Polsce bardzo mało dzieci. W roku 2012 ogólny współczynnik dzietności ${ }^{1}$ dla Polski wyniósł 1,30. Tak niski przyrost naturalny dawał naszemu krajowi drugie miejsce wśród krajów o najniższej dzietności w Unii Europejskiej². Według prognozy demograficznej3 ${ }^{3}$ do roku 2035 nastąpi spadek ogólnej liczby ludności w Polsce o prawie $2 \mathrm{mln}$. W tym liczba dzieci zmniejszy się o ponad 1,2 mln, a liczba osób w wieku produkcyjnym o ponad 3,6 mln. Liczba osób starszych przeciwnie nie zmniejszy się, ale wzrośnie o około 2,8 mln. W ujęciu procentowym spadek ludności będzie wynosił $18 \%$, w tym dzieci $22 \%$, a osób dorosłych $14 \%$. Natomiast osób starszych będzie więcej w roku 2035 o 44\% w stosunku do roku 2013. Zmiany te będą miały niekorzystny wpływ przede wszystkim na rozwój demograficzny i ekonomiczny kraju. Dlatego niezbędne jest podjęcie działań, które zatrzymałyby ten niekorzystny proces.

1 Ogólny współczynnik dzietności oznacza liczbę dzieci, które urodziłaby przeciętnie kobieta w czasie całego okresu rozrodczego (15-45), przy założeniu, że w poszczególnych fazach tego okresu rodziłaby z intensywnością obserwowaną w badanym roku. Dla prostej zastępowalności pokoleń przyjmuje się, że współczynnik dzietności powinien wynosić 2,1. Por. GUS, <http://old.stat.gov.pl/gus/definicje_PLK_HTML.htm?id=POJ-1058.htm>, (dostęp: 3.07.2014).

2 Por. Eurostat, <http://epp.eurostat.ec.europa.eu/tgm/table.do?ta$\mathrm{b}=$ table\&init $=1 \&$ plugin $=1 \&$ language $=$ en $\&$ pcode $=$ tsdde220 $>, \quad$ (dostęp: 2.07.2014).

3 Por. Prognoza ludności na lata 2008-2035, <http://demografia.stat.gov.pl/ bazademografia/Prognoza.aspx>, (dostęp: 17.01.2013). 
Przeprowadzanych jest wiele badań z różnych dziedzin, w których poszukuje się przyczyn obniżania się dzietności, nie tylko w Polsce, ale również we wszystkich krajach europejskich. Badania te najczęściej koncentrują się na szukaniu czynników, które spowodowały tak intensywne zmniejszenie dzietności. Rzadko jednak bada się grupy osób, które mimo przeciwnych dla tego podejścia trendów decydują się na dużą liczbę dzieci i stają się rodzinami wielodzietnymi. Wydaje się, że zbadanie tej grupy osób mogłoby przyczynić się do znalezienia tych czynników, które decydują w obecnym społeczeństwie o wielodzietności. Pozwoliłoby to niewątpliwie na podjęcie bardziej skutecznych działań w zakresie wsparcia postaw i zachowań prowadzących do prokreacji w stosunku do większej grupy osób.

W badaniach, które zostaną omówione w niniejszym wystąpieniu wykorzystano 24 wywiady pogłębione, częściowo ustrukturyzowane, które przeprowadzono wśród rodziców dużych rodzin. Wywiady przeprowadzono na terenie aglomeracji warszawskiej ${ }^{4}$ w 2013 roku.

Przed przedstawieniem wyników badań zostanie zaprezentowana charakterystyka rodzin wielodzietnych w Polsce w ostatnim dziesięcioleciu. Zasygnalizowane będą również obecne poglądy młodych ludzi odnośnie do liczby planowanego potomstwa. Następnie omówione zostanie założenie teoretyczne, które zostało wybrane do analizy przeprowadzonych wywiadów. Na koniec oddamy głos samym rodzicom, którzy w wypowiedziach zaprezentują swoje przekonania i wynikające z nich postawy odnośnie do małżeństwa, rodziny, wychowania dzieci, prokreacji i obszarów powiązanych z dzietnością.

Wywiady przeprowadzono w Warszawie i podwarszawskich gminach: Izabelin, Otwock, Stare Babice. 


\section{Rodzina wielodzietna w Polsce}

Rodzina wielodzietna w Polsce to rodzina, która liczy trójkę lub więcej dzieci. Podstawą do wyodrębnienia rodzin wielodzietnych jest istnienie więzi między rodzicami i dziećmi (niekoniecznie biologicznej) ${ }^{5}$. Obecnie liczba rodzin wielodzietnych w Polsce przekracza milion.

Mimo, że ogólnie liczba rodzin między rokiem 2002 i 2011 (latami przeprowadzania ostatnich spisów) wzrosła, co było spowodowane wejściem w wiek zakładania rodziny wyżu demograficznego z lat 80-tych, liczba rodzin wielodzietnych wyraźnie zmalała. W roku 2002 było ich w kraju 1 362,8 tys., w tym z czwórką dzieci i więcej 428,3 tys. Dziewięć lat później, w 2011 roku, liczba rodzin wielodzietnych zmniejszyła się do 1 008,5 tys., w tym z czwórką dzieci i więcej wynosiła już tylko 273,3 tys. Odpowiednio w roku 2002 rodziny wielodzietne stanowiły 17,2\% wszystkich rodzin, a już w 2011 tylko 12,4\%. Powyższe dane $z$ podziałem na miasto i wieś pokazuje tabela $1^{6}$.

5 Por. Gospodarstwa domowe i rodziny. Charakterystyka demograficzna. Narodowy Spis Powszechny Ludności i Mieszkań 2011, GUS, Warszawa 2014, s. 46.

6 Por. tamże, s. 47 
Część I

Współczesna sytuacja demograficzna w Polsce

Tabela 1. Rodziny z dziećmi w latach 2002 i 2011

\begin{tabular}{|c|c|c|c|c|c|c|}
\hline \multirow{2}{*}{$\begin{array}{l}\text { Rodziny } \\
\text { z dziećmi }\end{array}$} & \multicolumn{2}{|c|}{ Ogółem } & \multicolumn{2}{|c|}{ Miasto } & \multicolumn{2}{|c|}{ Wieś } \\
\hline & 2002 & 2011 & 2002 & 2011 & 2002 & 2011 \\
\hline \multicolumn{7}{|l|}{ w tysiącach } \\
\hline Ogółem & 8001,1 & 8130,9 & 4984,4 & 4892,3 & 3016,7 & 3238,7 \\
\hline \multicolumn{7}{|l|}{$\mathrm{w}$ tym: } \\
\hline z 3 dzieci & 944,5 & 735,2 & 459,0 & 324,9 & 485,5 & 410,3 \\
\hline $\begin{array}{c}\text { z } 4 \text { i więcej } \\
\text { dzieci }\end{array}$ & 428,3 & 273,3 & 147,4 & 88,6 & 280,9 & 184,7 \\
\hline \multicolumn{7}{|c|}{ w odsetkach (struktura pionowa) } \\
\hline Ogółem & 100 & 100 & 100 & 100 & 100 & 100 \\
\hline \multicolumn{7}{|l|}{ w tym: } \\
\hline z 3 dzieci & 11,8 & 9,0 & 9,2 & 6,6 & 16,1 & 12,7 \\
\hline $\begin{array}{c}\text { z } 4 \text { i więcej } \\
\text { dzieci }\end{array}$ & 5,4 & 3,4 & 3,0 & 1,8 & 9,3 & 5,7 \\
\hline
\end{tabular}

Źródło: Gospodarstwa domowe i rodziny. Charakterystyka demograficzna. Narodowy Spis Powszechny Ludności i Mieszkań 2011, GUS, Warszawa 2014, s. 47.

Jak wspomniano wyżej, rodziny wielodzietne stanowiły 12,4\% wszystkich rodzin z dziećmi w 2011 roku, w tych rodzinach wychowywało się 2114776 dzieci $\mathrm{w}$ wieku do lat 24 pozostających na utrzymania rodziców ${ }^{7}$, tj. 24\% wszystkich dzieci w kraju. Jeśli weźmiemy pod uwagę tylko rodziny z 4 dzieci i więcej, które stanowią 3,4\% wszystkich rodzin w Polsce, to w nich wychowywało się $707128^{8}$ dzieci, tj. $8 \%$.

Rozpatrując sytuację ekonomiczną dzieci w rodzinach wielodzietnych, należy zwrócić uwagę na fakt, że od wielu lat jest ona bardzo trudna. Wraz ze wzrostem liczby dzieci dochód na członka rodziny drastycznie maleje. Ma

7 Por. Gospodarstwa domowe i rodziny. Charakterystyka demograficzna. Narodowy Spis Powszechny Ludności i Mieszkań 2011, GUS, Warszawa 2014, aneks tabelaryczny, <http://stat.gov.pl/obszary-tematyczne/ludnosc/narodowy-spis-powszechny-ludnosci-i-mieszkan-2011/gospodarstwa-domowe-i-rodziny-charakterystyka-demograficzna-nsp-2011,30,1.html>, (dostęp: 20.09.2014).

8 Por. tamże. 
to swoje konsekwencje w zaspokajaniu podstawowych potrzeb. Wykres 1 ilustruje brak zaspokajania potrzeb żywieniowych $\mathrm{w}$ rodzinach $\mathrm{z}$ jednym, dwojgiem oraz trojgiem i więcej dziećmi. Wynika z tego, że 8,5\% rodzin wielodzietnych nie jest w stanie zapewnić - przynajmniej, co drugi dzień - swoim członkom posiłków z mięsem, drobiem, rybą lub wegeteriańskim substytutem. W rodzinach z jednym dzieckiem ten odsetek wynosi 1,9\%, a z dwójką dzieci $-2,7 \%$.

Wykres 1. Brak możliwości zaspokajania potrzeb żywieniowych $\mathrm{w}$ gospodarstwach domowych $\mathrm{w}$ Polsce
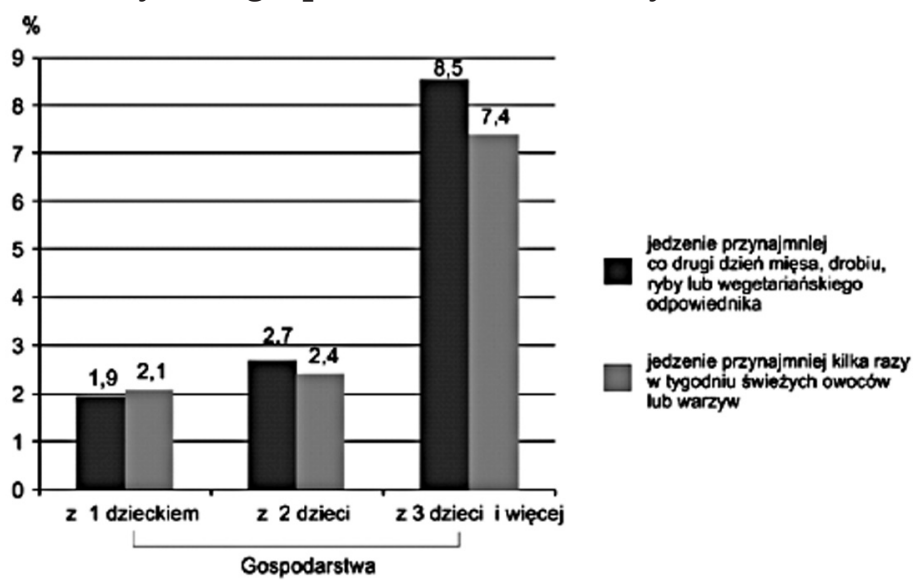

Źródło: Warunki życia rodzin w Polsce, GUS 2014, <http://stat.gov.pl/obszary-tematyczne/warunki-zycia/dochody-wydatki-i-warunki-zycia-ludnosci/ warunki-zycia-rodzin-w-polsce,13,1.html>, (dostęp: 22.06.2014), s. 41.

Podobnie wygląda sprawa z zakupem podręczników szkolnych. Trudności w ich zakupie deklarowało $14 \%$ rodzin z 3 i więcej dzieci. Ponad to, około 30\% rodzin wielodzietnych nie było stać na posyłanie dzieci na płatne zajęcia rozwijające ich zdolności lub zajęcia wyrównawcze. W rodzinach małodzietnych jedynie $14 \%$ sygnalizowało ten problem. Także potrzeby zdrowotne są w mniejszym stopniu zaspokajane $\mathrm{w}$ rodzinach, gdzie jest trójka lub więcej dzieci. Z płatnych wizyt u lekarzy rezygnuje około 
5\% rodzin z jednym dzieckiem i z dwójką dzieci, a aż 10\% rodzin wielodzietnych. Ograniczanie zakupu koniecznych leków występuje u 2,6\% rodzin mających 1 dziecko i u $6,7 \%$ rodzin z 3 i więcej dzieci.

Biorąc pod uwagę typ rodziny, w której wychowywały się dzieci w wieku 0-24 lata pozostające na utrzymaniu rodziców, najliczniejszą grupę stanowiły małżeństwa. Wychowywało się w nich 77,1\% wszystkich dzieci, 20,3\% dzieci było wychowywanych przez samotnych rodziców i 2,6\% w związkach nieformalnych.

W rodzinach wielodzietnych $83 \%$ dzieci do lat 24 pozostających na utrzymaniu wychowywało się w rodzinach opartych na małżeństwie, 13\% dzieci wychowywanych było przez samotne matki, 3\% w konkubinatach, a 1\% przez samotnych ojców. Dla porównania, w rodzinach małodzietnych $75 \%$ dzieci wychowywanych był przez małżeństwa, 20\% przez samotne matki, 3\% w konkubinatach, a $2 \%$ przez samotnych ojców ${ }^{9}$. Na podstawie przedstawionych danych można wnioskować, że dzieci będące w rodzinach wielodzietnych częściej są wychowywane przez oboje rodziców będących w związku małżeńskim.

W rodzinach wielodzietnych obserwuje się również mniej rozwodów. W roku 2011 w rodzinach $\mathrm{z}$ jednym i dwójką dzieci rozwiodło się 37692 małżeństw, co stanowiło $0,46 \%$ tych rodzin. Natomiast w rodzinach z trójką dzieci liczba rozwodów wyniosła 1883 i było to 0,26\% tych rodzin, a z czwórką i większą liczbą dzieci było 518 rozwodów, co stanowi odpowiednio 0,19\%. Dane te wskazuja, że związki małżeńskie, gdzie jest więcej dzieci, są bardziej trwałe.

Rozpatrując kolejność urodzeń, to znaczy, jaki procent wszystkich urodzeń w danym roku przypadał na urodzenia pierwsze, drugie, trzecie, czwarte i dalsze, można zaobserwować, że w ostatnich latach procent urodzeń

9 Obliczenia własne na podstawie danych GUS, <http://stat.gov.pl/obszary-tematyczne/ludnosc/narodowy-spis-powszechny-ludnosci-imieszkan-2011/gospodarstwa-domowe-i-rodziny-charakterystyka-demograficzna-nsp-2011,30,1.html>, (dostęp: 16.08.2014). 
trzecich pozostaje mniej więcej na tym samym poziomie, a czwartych i dalszych maleje. W 2006 roku trzecich urodzeń było 10,01\%, a czwartych i dalszych 6,02\%, natomiast w 2011 roku odpowiednio było ich 10,16\% i 4,75\%. Biorąc pod uwagę wykształcenie matek, które rodzą trzecie, czwarte i kolejne dzieci, w okresie 2006-2011 następował niewielki, ale systematyczny wzrost udziału matek mających wyższe wykształcenie. W 2006 roku wśród matek rodzących 3 dziecko 5,71\% miało wyższe wykształcenie, a pięć lat później 6,56\%. Dla 4 i dalszych urodzeń wzrost dał się również zaobserwować, ale był mniejszy: z 1,33\% do $1,39 \%{ }^{10}$.

Jeśli chodzi o plany prokreacyjne młodych ludzi odnośnie do posiadania rodziny wielodzietnej, można w ostatnim czasie zaobserwować wzrost chęci posiadania trójki dzieci. W 2000 roku 19\% osób deklarowało, że chciałoby mieć trójkę dzieci, a w 2012 r. - 25\%. Natomiast, jeśli chodzi o deklaracje odnośnie do posiadania czwórki dzieci, procent takich osób zmalał z $6 \%$ do $4 \%$ w tym samym okresie. W przypadku 5 i więcej dzieci również zmalał odsetek osób chcących posiadać tak liczne potomstwo, odpowiednio z 4\% w 2000r. do 2\% w 2012 r. ${ }^{11}$.

Odnośnie do chęci posiadania dzieci w ogóle, badania pokazuja że mężczyźni dwa razy częściej deklaruja, że chcieliby mieć potomstwo niż kobiety. Także osoby z wyższym wykształceniem częściej mają plany posiadania potomstwa. Czynnikiem, który również w znaczący sposób wpływa na plany prokreacyjne, jest religijność. U osób silnie utożsamiających się z wartościami chrześcijańskimi planowanie potomstwa jest ponad dwukrotnie częstsze niż u osób odcinających się od jakichkolwiek związków z religią i Kościołem ${ }^{12}$.

\footnotetext{
10 Por. Sytuacja demograficzna Polski. Raport 2011-2012, Rządowa Rada Ludnościowa, Warszawa 2012, s. 110-111.

11 Por. Potrzeby prokreacyjne oraz preferowany i realizowany model rodziny, komunikat $z$ badań CBOS, BS/52/2006, s. 2 i komunikat $\mathrm{z}$ badań CBOS, BS/61/2012, s. 2.

12 Por. tamże.
} 


\section{Część I}

Współczesna sytuacja demograficzna w Polsce

Nie wiadomo, w jakim stopniu obecnie reprezentowane poglądy młodych osób przełożą się na praktykę. W moim wystąpieniu skoncentruję się na uzyskaniu odpowiedzi na pytanie: Jakie przekonania i postawy mają osoby, które już są rodzicami trójki lub większej liczby dzieci?

\section{Podejście teoretyczne - decyzje prokreacyjne}

Podejściem teoretycznym zastosowanym do analizy danych zebranych $\mathrm{w}$ badaniu jest Teoria Planowanego Zachowania - TPZ (Theory of Planned Behaviour), która została przedstawiona przez I. Ajzena ${ }^{13}$. Teoria ta powstała w celu wyjaśnienia społecznych zachowań człowieka. W ostatnim czasie TPZ została przez jej autora dostosowana do zachowań człowieka nakierowanych na prokreację $^{14}$. Zastosowanie TPZ może pomóc w lepszym zrozumieniu zachowań prokreacyjnych oraz dać możliwość wpływu na społeczno-psychologiczny proces prowadzący do pragnienia lub unikania posiadania dziecka.

Według omawianej teorii, aby dana osoba zachowywała się w konkretny sposób, musi mieć uformowaną mocną pozytywną intencję co do podjęcia danego działania oraz kontrolę nad tym działaniem. Jeśli posiadanie lub nieposiadanie dziecka zależy od danej osoby, tzn. jeśli ma ona nad tym kontrolę, to jej działanie zależy od intencji. Intencja co do posiadania dziecka jest formowana przez trzy rodzaje czynników: postawy, normy subiektywne, poczucie kontroli (attitudes, subjective norm, perceived control). Graficzne przedstawienie teorii ilustruje rysunek 1.

13 I. Ajzen, The theory of Planned Behavior, "Organizational Behavior and Human Decision Processes" (1991), nr 50, s. 179-211 [doi:10.1016/07495978(91)90020] i T. M. Fishbein, I. Ajzen, Predicting and Changing Behavior - the Reasoned Action Approach, Psychology Press Taylor \& Francis, New York 2010.

14 I. Ajzen, J. Klobas, Fertility intentions: An approched based on the theory of planned behavior, Demographic Research 2013, volume 29, article 8, s. 203-232, <http://www.demographic-research.org/volumes/vo129/8/29-8.pdf>, (dostęp: 17.08.2014). 


\section{Rysunek 1. Teoria Planowanego Zachowania}

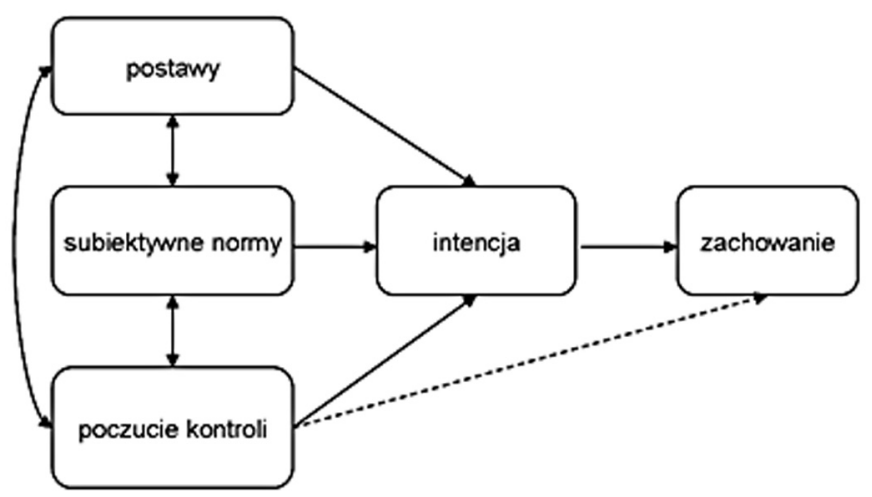

Źródło: I. Ajzen, The theory of Planned Behavior, "Organizational Behaviour and Human Decision Processes" (1991), nr 50, s. 182.

Wpływ na poszczególne rodzaje czynników mają odpowiednie przekonania. Na postawy ma wpływ przekonanie o wartości danego zachowania (behavioral beliefs). Przekonanie polega na spodziewaniu się dla siebie konsekwencji pozytywnych lub negatywnych z faktu posiadania dziecka i przypisywaniu temu faktowi osobistej wagi. Wszystkie przekonania na temat wartości posiadania lub nieposiadania dziecka prowadzą do powstania pozytywnej lub negatywnej postawy co do posiadania dzieci (attitudes toword having children). Postawy co do posiadania dzieci wpływają następnie na intencję. Im wyższa jest wartość subiektywna przypisywana posiadaniu dzieci, tym silniejsza jest intencja, aby posiadać dzieci. Inaczej można powiedzieć, że im bardziej pozytywna jest postawa wobec faktu posiadania dziecka, tym większa jest intencja (chęć), aby mieć dziecko.

Przekonania co do społecznego przyzwolenia, aby mieć dzieci (belifes about social suport for having a child) mają wpływ na subiektywną normę (subjective norm). Subiektywna norma odnośnie do posiadania dzieci związana 


\section{Część I}

Współczesna sytuacja demograficzna w Polsce

jest ze sposobem postrzegania oczekiwań odnośnie do prokreacji, jakie ma najbliższe lub dalsze otoczenie danej osoby. Oczekiwania moga być formułowane w sposób nakazowy (injunctive) i opisowy (descriptive). Nakazowe przekonanie jest tworzone na podstawie tego, co inni nam mówią, lub wynika z naszego wnioskowania, co chcieliby, abyśmy zrobili, np. moi rodzice uważają, że powinniśmy mieć czworo dzieci. Opisowe przekonanie, jest zwykle tworzone na podstawie tego, co obserwujemy u innych. Osobami znaczącymi dla podejmowania decyzji o rodzicielstwie są przede wszystkim: współmałżonek ${ }^{15}$, rodzice $^{16}$ i przyjaciele ${ }^{17}$.

Większość badań koncentruje się na nakazowym formułowaniu norm. Przykładem takich badań są badania przeprowadzone w Polsce w 1990 roku w ramach Centralnego Programu Badań Podstawowych ${ }^{18}$ oraz europejskie badanie Generations and Gender Survey ${ }^{19}$, w których znalazło się pytanie o opinie innych na temat posiadania przez respondenta dzieci. Badacze również wskazują na znaczenie opisowych norm, które odnoszą się, $\mathrm{z}$ jednej strony, do liczby dzieci w rodzinie macierzystej ${ }^{20}$, a z drugiej, do liczby dzieci w rodzinach przyjaciół ${ }^{21}$. Zarówno przekonania nakazowe, jak i opisowe tworzą normę subiektywną, która polega na chęci dostosowania się

15 Por. E. Thomson, Couple childbearing desires, intentions, and births, "Demography" (1997), nr 34(3), s. 343-354.

16 Por. J.S. Barber, Intergenerational influences on the entry into parenthood: Mothers' preferences for family and nonfamily behavior, "Social Forces" (2000), nr 79(1), s. 319-348.

17 Por. P.L. East, M.E. Felice, M.C. Morgan, Sisters' and girlfriends' sexual and childbearing behaviour: Effects on early adolescent girls' sexual outcomes, "Jorunal of Marriage and the Family" (1993), nr 55(4), s. 953-963.

18 Por B. Hałaczek, K. Ostrowska, Uwarunkowania dzietności kobiet w Polsce, Centralny Program Badań Podstawowych CPBP 08.03/III/2, Warszawa 1990, s. 93-94.

19 Por. Kwestionariusz polski - wave1, pytanie 127, s. 22, <http://www.ggp-i. org/data/questionnaires.html>, (dostęp: 17.08.2014).

20 Por. B. Hałaczek, K. Ostrowska, Uwarunkowania dzietności kobiet w Polsce, dz. cyt., s. 94.

21 Por. P.L. East, M.E. Felice, M.C. Morgan, Sisters' and girlfriends' sexual and childbearing behaviour, dz. cyt., s. 953-963. 
do oczekiwań osób znaczących czy obserwowanych zachowań.

Przekonanie o czynnikach umożliwiających lub nie (beliefs about enabling or interfering factors) posiadanie dzieci ma wpływ na poczucie kontroli. Przekonanie o kontroli bierze pod uwagę zasoby, które mogą ułatwiać, i przeszkody, które mogą utrudniać posiadanie dzieci. W zależności od wagi branych pod uwagę czynników, tworzy się poczucie kontroli nad posiadaniem dziecka. Należy zaznaczyć, że poczucie kontroli to co innego niż ograniczenie lub odczuwanie ograniczenia. W odniesieniu do dzietności, brak odpowiedniego miejsca zamieszkania jest postrzegany jako poważna przeszkoda dla urodzenia dziecka. Przy badaniu wpływu posiadania mieszkania należy wziąć pod uwagę nie tylko fakt posiadania odpowiedniego mieszkania, ale również przekonanie osoby, co do ważności odpowiedniego miejsca zamieszkania przy planowaniu liczby dzieci.

Opisane wyżej trzy rodzaje czynników wpływają na intencję co do posiadania lub nieposiadania dzieci. Do zrealizowania intencji potrzebna jest jeszcze faktyczna kontrola (actual control) nad zachowaniem (na przykład, małżonkowie chcą mieć w sposób naturalny dziecko, ale nie może dojść do poczęcia). Ponadto, po powstaniu intencji posiadania dziecka, może również dojść do zmiany co do poczucia kontroli. Na przykład, utrata pracy, może, choć niekoniecznie musi, wpłynąć na zmianę zachowania prokreacyjnego pary, ponieważ na poczucie kontroli ma wpływ sposób, w jaki utrata pracy ma znaczenie dla planów prokreacyjnych. Może być tak, że kobieta, która straciła pracę, tym bardziej chce mieć dziecko, ponieważ uważa, że będzie miała czas na opiekę nad małym dzieckiem. Graficzne przedstawienie teorii TBZ dostosowanej do zachowań nakierowanych na prokreację pokazuje rysunek 2 . 
Rysunek 2. Teoria Planowanego Zachowania dostosowana do decyzji prokreacyjnych

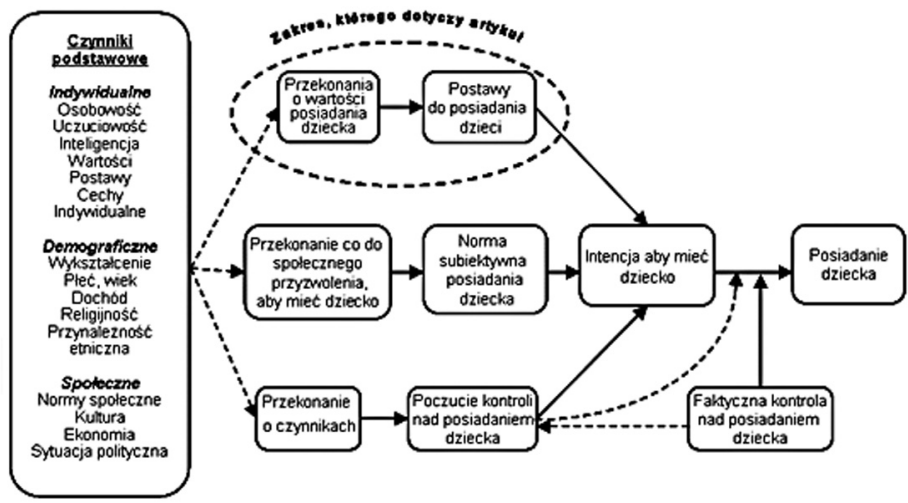

Źródło: I. Ajzen, J. Klobas, Fertility intentions: An approched based on the theory of planned behavior, Demographic Research 2013, volume 29, article 8, s. 206, <http://www.demographic-research.org/volumes/vol29/8/29-8.pdf>, (dostęp: 17.08.2014).

W artykule tym przedstawione zostaną jedynie przekonania i wynikające z nich postawy, które kształtują intencję, a w rezultacie zachowania wpływające na posiadanie dużej rodziny. Na rysunku 2 zostały one zaznaczone pętlą. Przy badaniu przekonań i postaw wśród rodziców dużych rodzin na uwagę zasługuje fakt, że ta grupa czynników jest wymieniana przez respondentów jako najbardziej istotna dla ich zachowań skutkujących pojawieniem się kolejnych dzieci. W tej grupie osób czynniki należące do subiektywnego poczucia kontroli przede wszystkim są odpowiedzialne za odkładanie poczęcia lub zakończenie prokreacji.

Ogólne pytanie badawcze $\mathrm{w}$ tym artykule brzmi: jakie przekonania i wynikające $\mathrm{z}$ nich postawy prowadzą do zachowań prokreacyjnych u osób posiadających duże rodziny? 


\section{Zastosowana metoda i próba}

Ze względu na otwarty charakter pytania badawczego oraz nastawienie na badanie procesu i poznanie subiektywnego spojrzenia respondentów, właściwe jest zastosowanie metody jakościowej. Należy podkreślić, że przydatność metody jakościowej przy badaniach demograficznych jest coraz bardziej rozpoznawana przez badaczy $^{22}$. Nierzadko stanowi ona swego rodzaju wstęp do badań statystycznych przez wyodrębnienie czynników mających wpływ na badane zjawisko i opis powiązań zachodzących między nimi.

Materiały wykorzystane $\mathrm{w}$ badaniu pochodzą $\mathrm{z}$ wywiadów przeprowadzonych w roku 2013 wśród rodziców dużych rodzin, którzy zamieszkiwali teren aglomeracji warszawskiej oraz posiadali wykształcenie średnie lub wyższe. Powodem wyboru takiej grupy był obserwowany od początku lat 90 . wzrost liczby urodzeń czwartych i kolejnych dzieci wśród osób z wyższym wykształceniem zamieszkujących miasta ${ }^{23}$ i aglomeracje miejskie. Przy ogólnym spadku urodzeń w Polsce, szczególnie urodzeń czwartych i wyższych, pojawia się grupa osób, które decydują się na urodzenie większej liczby dzieci.

Ogółem przeprowadzono 24 wywiady w 12 rodzinach. Do badania wybrane zostały rodziny, które miały trójkę lub więcej dzieci, ponieważ zgodnie z polskim ustawodawstwem uważane są za wielodzietne. Rodziny te zbudowane były na związku małżeńskim. W badaniu zależało mi na tym, aby rodzice tworzyli środowisko, które potencjalnie jest najbardziej od powiednie do wychowania dzieci. Badaniem udało się objąć wszystkich ojców i matki. Przedział wiekowy badanych kobiet to 32 do 53 lat, a mężczyzn - 33 do 52 lat. Siedem spośród badanych ro-

22 Por. E. Frątczak, M. Młynarska, Badania jakościowe na użytek demografii, "Studia Demograficzne” 2007, nr 2(152), s. 3-22.

23 Por. Kancelaria Rady Ministrów, Raport o sytuacji polskich rodzin, Warszawa 1998, s. 32; Rządowa Rada Ludnościowa, Sytuacja demograficzna Polski. Raport 2011-2012, Warszawa 2012, s. 110-111. 
dzin miało 4 dzieci, dwie rodziny 3 dzieci, po jednej rodzinie było z 5, 6 i 7 dzieci. 20 respondentów miało wyższe wykształcenie, a 4 średnie.

W prowadzonym badaniu jakościowym przyjęto metodę wywiadu nakierowanego na problem, obserwację i kwestionariusz.

\section{Przekonania i postawy prowadzące do prokreacji $\mathrm{w}$ wypowiedziach rodziców $\mathrm{w}$ rodzinach wielodziet- nych}

Dla postawionego pytania badawczego przede wszystkim znaczenie mają wypowiedzi respondentów ukazujące przekonania i postawy, które prowadziły do posiadania licznego potomstwa. Na uwagę zasługuje fakt, że u wszystkich respondentów chęć posiadania większej liczby dzieci jest połączona z przypisywaniem dużej wartości małżeństwu, dziecku i rodzinie. Dlatego też, na początku zaprezentowane zostaną przekonania respondentów na temat małżeństwa, dziecka i rodziny, a następnie ich postawy prowadzące do urodzenia większej liczby dzieci.

(a) Małżeństwo

Małżeństwo przez wszystkich respondentów jest uważane za związek trwały i nierozerwalny oraz wyraz miłości i wolnej decyzji małżonków. Respondenci wymieniają trzy przyczyny patrzenia na małżeństwo jako na związek trwały i nierozerwalny. Taki pogląd jest wynikiem: wzoru wyniesionego z domu; wiary, którą wyznają i przekonania co do niezbędności tworzenia związku trwałego dla dobra małżonków i dzieci.

Pierwsza przyczyna to wzór wyniesiony z domu rodzinnego. Wszyscy badani, poza dwiema osobami, pochodzili z rodzin pełnych, tzn. rodzice nie rozwiedli się i był to ich pierwszy związek małżeński. Choć związki rodziców i relacje między nimi respondenci opisywali bardzo różnie: od bardzo pozytywnych stwierdzeń do bardzo negatywnych, których nie chcieliby w swoim ży- 


\section{Część I}

Współczesna sytuacja demograficzna w Polsce

ciu powielać, wszyscy respondenci bardzo wysoko cenili trwałość małżeństwa.

Moi rodzice tworzyli bardzo zgodne małżeństwo przepojone miłością. To był wzór dla mnie, dla moich koleżanek. Tworzyli bardzo zgodna parę do końca swoich dni. R405, Kobieta, 53, $4 d z i e c i^{24}$.

Przede wszystkim dostrzegałem u nich (rodziców) rzeczy, których sam nie chciałem mieć w małżeństwie. Opisałbym te relację, że sprowadzała się ona do życia pod jednym dachem $i$ wspólnej odpowiedzialności za dzieci. W wielu aspektach relacji między nimi nie było. Opisałbym ja jako słaba.. R3011, Mężcz., 34, 3 dzieci.

Jak już zostało wspomniane wyżej, wśród badanych były dwie osoby, która nie miały wzoru wierności małżeńskiej w domu rodzinnym. Dla jednej z nich związek jej ojca z matką był drugim związkiem. Rodzice drugiej osoby rozwiedli się. Jednak były osobami przekonanymi o wartości małżeństwa.

Mama sama nas wychowywata, ale w takim duchu, że matżeństwo ma ogromna wartość. Mimo zdrad i odejścia ojca, do końca życia była mu wierna. Od niej nauczyliśmy się, jak można być wiernym drugiej osobie nawet, jeśli ona nie jest. R5012, Kobieta, 47, 3 dzieci.

Drugi czynnik, jakim jest wyznawana wiara, stanowi bardzo ważną przyczynę wysokiej oceny małżeństwa przez respondentów i uznawania, że jest to związek na całe życie. Rozwody są postrzegane jako bardzo duże nieszczęście dla rodziny.

24 Symbole przy cytatach oznaczają: R405 - rodzinę, przy czym pierwsza cyfra oznacza liczbę dzieci w rodzinie, a druga cyfra numer rodziny; następnie jest określona płeć; wiek respondenta; liczba dzieci w rodzinie. 
Przede wszystkim byłem wychowany watmosferze religijnej, że małżeństwo jest ogromna wartościa. Całe szczęście nie było rozwodów, nie było dużo rozwodów w bliższej i dalszej rodzinie. Do dzisiaj rozwód jest w moich oczach jakaśs straszna tragedia, bardzo ubolewamy (z żona), jak wśród naszych znajomych ktoś się rozwodzi. R608, Mężcz., 52, 6 dzieci.

Wszystkie badane pary miały ślub kościelny i był to ich jedyny związek, jaki do tej pory utworzyły. Wszystkie, oprócz jednej pary, zawarły ślub w Kościele Katolickim. Jedna para małżonków pobrała się w Kościele Zielonoświątkowców. Wszyscy małżonkowie w czasie badania uznawali nierozerwalność małżeństwa.

Ostatnią przesłanką przyczyniająca się do uważania małżeństwa za związek nierozerwalny, wymienianą przez respondentów, było przekonanie, że jedynie trwały związek sprzyja wielodzietności, ponieważ zapewnia poczucie bezpieczeństwa dla małżonków i wzajemne wsparcie przy wychowaniu dzieci.

Dla mnie, jako kobiety, pierwszym najważniejszym czynnikiem, który sprzyja, aby mieć dużo dzieci jest to, że mam kochającego męża, po pierwsze mam męża, nie jakiegoś partnera, nie wiem. Mam męża, który podziela moje wartości i czuję się bezpieczna. W tym sensie, nie wiem czy nie musze, ale nie martwię sie, że urodze dziecko i zostane sama. Wiem, że mój mą̇ przy mnie będzie i będziemy razem i będzie mi pomagat. R409, Kobieta, 37, 4 dzieci.

Małżonkowie, opisując swój okres przedmałżeński, mówili o pragnieniu budowania trwałego małżeństwa. Dla utworzenia takiego związku, jak opisuje jedna z respondentek, warto było nawet zaryzykować utratę budowanej już od dłuższego czasu relacji z daną osobą. Jak

mówi respondentka, jakość przyszłego małżeństwa była dla niej ważniejsza niż w ogóle jego zawarcie. 
W pewien sposób to było takie ryzyko, ale z drugiej strony to wiedziatam, że albo to będzie porzadne, albo nie ma, co sobie głowy zawracać, tak? Wydaje mi się, że to zaowocowało, zaczęliśmy dopiero wtedy się spotykać, jak to było możliwe, na takich zasadach, na jakiś chcieliśmy, żeby to było trwałe. R409, Kobieta, 37, 4 dzieci.

Badani małżonkowie uważają również, że małżeństwo powinno być wyrazem wzajemnej miłości oraz wolnej decyzji małżonków. Charakterystycznym podejściem respondentów do małżeństwa jest zwracanie uwagi na wolność decyzji drugiej osoby, nie zniewalanie jej również swoimi pragnieniami czy uczuciem. Poniżej opis dialogu wewnętrznego, jaki podała jedna $z$ badanych osób.

Próbowałam tak rozważyć, na czym mi zależy, tak jak mi się nie oświadczył. Zaczęto mi zależeć, i zaczętam się bać - bo oczywiście może tak jeszcze w pewnym momencie powiedzieć: "No wiesz fajnie się spotykać, ale wiesz.(...)". No nie, każdy ma prawo do szukania drogi swojej do miłości. No powiem mu, dobrze mi było z nim, no, ale trudno nie będe mu stała na drodze. R404, Kobieta, 34, 4 dzieci.

Na wartość małżeństwa w wypowiedziach respondentów wskazuje również zestaw cech współmałżonka, jakie były dla nich ważne przy podejmowaniu decyzji o zawarciu związku małżeńskiego tak, aby był to związek trwały i szczęśliwy. Występują tutaj wyraźne różnice między cechami, jakie są ważne dla mężczyzn i kobiet. Dwie cechy dla obu płci są takie same. Są to: zgodność poglądów i wiara. Zostaną one przedstawione w pierwszej kolejności, następnie omówione zostaną pozostałe cechy z podziałem na płeć.

Zgodności poglądów między małżonkami wynikała zdaniem respondentów albo $\mathrm{z}$ podobnych domów, w jakich byli wychowywani, albo z takiego samego środowiska, w jakim przebywali w młodości. Jak mówią respondenci, to bardzo pomagało w budowaniu rodziny. 


\section{Część I}

Współczesna sytuacja demograficzna w Polsce

Poza tym, bardzo dużo ze soba rozmawialiśmy, ja nawet myślałam, że mnie trochę oszukuje, bo mamy takie same poglady. We wszystkim się ze mna zgadzat. Ale z bardzo podobnych rodzin wywodziliśmy sie, jego rodzice tak podobnie wychowywali, jak mnie. R405, Kobieta, 53, 4 dzieci.

Chyba najbardziej to, że mieliśmy takie wspólne patrzenie, jeżeli chodzi o jakaś tam przyszłość. Nie było nam łatwo zejść się ze sobq, ale jesteśmy. Ten wspólny kierunek z przeszłości (skauting). R409, Mężcz., 37, 4 dzieci.

Drugą cechą u osoby, którą chcieli poślubić, ważną dla respondentów obu płci, było wyznawanie tej samej wiary. Jak uważała zdecydowana większość badanych, nie mogliby związać się z osobą niewierząca, ponieważ, jak mówi jedna z respondentek, trudno byłoby poradzić sobie w życiu, jeśli nie byłoby wspólnego zrozumienia w kwestiach wiary.

O naszych wartościach rozmawialiśmy dużo. Ja, ponieważ znałam mojego męża już od jakichś kilkunastu lat przed ślubem, jego rodziców, braci. To, że jest człowiekiem wierzacym, praktykujacym, była to dla mnie sprawa bardzo ważna, a też oczywiste w pewien sposób. To było bardzo ważne i na tym można było wręcz budować. Wiadomo, że człowiek w swoim życiu napotyka trudności, ale jak nie ma w swoim życiu takiej bazy, punktu odniesienia, który jest tak w perspektywie wiecznej, to trudno byłoby sobie poradzić. Nawet już w czasach narzeczeństwa, nie mówiąc małżeństwa. R409, Kobieta, 37, 4 dzieci.

Choć dla niektórych respondentów wiara w momencie zawierania małżeństwa nie była tak istotna jak jest obecnie, to jednak uważaja że nie mogliby poślubić osoby, która nie dzieliłaby ich przekonań religijnych.

Jeśli chodzi o wartości religijne, to wtedy to nie miało takiego znaczenia jak teraz. To było jakoś tak w tle. Raczej nie zdecydowałbym się na ślub z kobieta, która nie dzieliłaby moich przekonań religijnych. R4010, Mężcz., 37, 4 dzieci. 
Myśmy też byli w duszpasterstwie i ja o poczatku wiedziałam, że Bóg jest dla niego bardzo ważny. On też był w duszpasterstwie, gdzieś tam się udzielał. Ja chyba od początku wiedziałam, że nie byłabym w stanie wyjść za mażz za kogoś, kto pewnych rzeczy nie rozumie. To było dla mnie oczywiste. Do dzisiaj uwa$\dot{z} a m, \dot{z} e$ na tym właśnie budujemy, że ... to było dla mnie ważne, kluczowe i na samym początku się upewniłam, o co chodzi. Jak on te sprawy postrzega. R4010, Kobieta, 36, 4 dzieci.

Wyznawanie tej samej wiary przez współmałżonków stawało się również podstawą do określania tych samych wartości, według których chcieliby budować swoje małżeństwo i rodzinę. Charakterystyczne jest dla badanej grupy, że choć przyszli małżonkowie poznawali się w różnych środowiskach, takich jak szkoła, studia, znajomi, ponad połowa par poznała się w środowisku wspólnot religijnych czy na pielgrzymkach. Wspólna wiara i zaangażowanie religijne, według respondentów, dawało większą możliwość budowania trwałego związku.

(...) jak sie poznaliśmy to już wiedzieliśmy o sobie, że jesteśmy we wspólnocie (religijnej). Więc jak się spotykaliśmy, to szliśmy na Mszę św., odmawialiśmy razem różaniec. Widać było, że byliśmy jednego ducha. R608, Kobieta, 47, 6 dzieci.

Jeśli chodzi o cechy przyszłych współmałżonków, które były ważne dla respondentek, były to: odpowiedzialność, wierność danemu słowu, opiekuńczość, dawanie poczucia bezpieczeństwa, prawdomówność, męskość, brak nałogów i ostatnia cecha szczególnie ważna przy większej liczbie dzieci - pozytywny do nich stosunek. Poniżej w tabeli przedstawione są te cechy, które zostały wymienione przez co najmniej dwie respondentki. 


\section{Część I}

Współczesna sytuacja demograficzna w Polsce

Tabela 2. Cechy przyszłych mężów wymieniane przez przynajmniej dwie respondentki

\begin{tabular}{|c|c|}
\hline $\begin{array}{l}\text { Przyszły mąż } \\
\text { jest: }\end{array}$ & Przykład \\
\hline Odpowiedzialny & $\begin{array}{l}\text { Zaimponował mi, że jest takim człowie- } \\
\text { kiem odpowiedzialnym. Zaimponowa- } \\
\text { ła mi jego męskości w takim wydaniu } \\
\text { właśnie jak to widzę, a więc stabilność } \\
\text { emocjonalna i odpowiedzialnośc. R4010, } \\
\text { Kobieta, 36, } 4 \text { dzieci }\end{array}$ \\
\hline $\begin{array}{l}\text { Wierny danemu } \\
\text { słowu }\end{array}$ & $\begin{array}{l}\text { Czułam, że jak ta osoba powie jakieś sło- } \\
\text { wo, to będzie to na lata. R4010, Kobieta, } \\
\text { 36, } 4 \text { dzieci }\end{array}$ \\
\hline $\begin{array}{l}\text { Opiekuńczy, } \\
\text { ciepły }\end{array}$ & $\begin{array}{l}\text { Opiekuńczość, ciepło mi się spodobało, } \\
\text { po trzech latach się pobraliśmy, R702, } \\
\text { Kobieta, } 49,7 \text { dzieci (...) był ciepły opie- } \\
\text { kuńczy, no ogólnie, na czynniki pierw- } \\
\text { sze to tak trudno rozebrać R301, Kobieta, } \\
\text { 47, } 3 \text { dzieci }\end{array}$ \\
\hline $\begin{array}{l}\text { Dający poczucie } \\
\text { bezpieczeństwa }\end{array}$ & $\begin{array}{l}\text { Czułam bezpieczeństwo przy nim i bar- } \\
\text { dzo się czułam kobieca. Tak mnie pocią- } \\
\text { gnął swoją męskością. R4010, Kobieta, } \\
\text { 36, } 4 \text { dzieci }\end{array}$ \\
\hline $\begin{array}{l}\text { Prawdomówny, } \\
\text { szczery }\end{array}$ & $\begin{array}{l}\text { (...) nie mieszał, był bardzo szczery, otwar- } \\
\text { ty, nie mieszał. R3011k, Kobieta, } 33 \text { lata } \\
3 \text { dzieci }\end{array}$ \\
\hline Męski & $\begin{array}{l}\text { Po tych kilku latach przerwy w czasie stu- } \\
\text { diów, to pierwsza rzecz, jaka mnie uderzyła, } \\
\text { to w tym moim mężu to, że stał się mężczy- } \\
\text { zną, przestał być chłopcem, w pewien sposób } \\
\text { takim nawet wojownikiem. Jakby wiedział, } \\
\text { czego chce, był taki stanowczy, był taki mę- } \\
\text { ski. Widzący, w którą stronę idzie, co chce } \\
\text { osiągnąć. I to tak mnie uderzyło. R409, Ko- } \\
\text { bieta, 37, } 4 \text { dzieci }\end{array}$ \\
\hline $\begin{array}{l}\text { Pozytywnie } \\
\text { nastawiony do } \\
\text { dzieci }\end{array}$ & $\begin{array}{l}\text { Obserwowałam też raz, jak odnosi się do } \\
\text { dzieci, jak byliśmy u naszej rodziny. Jak taka } \\
\text { mała dziewczynka się z nim bawi, jaki jest do } \\
\text { dzieci. R404, Kobieta, } 34,4 \text { dzieci }\end{array}$ \\
\hline
\end{tabular}


Natomiast respondenci wymieniali zdecydowanie mniej cech swoich przyszłych żon, które zadecydowały o ich wyborze. Charakterystyczne jest również, że prawie połowa mężczyzn nie wymieniała cech przyszłej żony, które mogłyby zadecydować o decyzji małżeństwa, ale mówiła o zakochaniu się.

Jak sie poznaliśmy, ja jestem człowiekiem konkretnym, zobaczyłem fajna dziewczyne i zgarnąłem ją. R407, Mężcz., 38, 4 dzieci

Ja zakochałem się. R403, Mężcz., 50, 4 dzieci.

Tabela 3. Cechy przyszłych żon wymieniane przez przynajmniej dwóch respondentów

\begin{tabular}{|l|l|}
\hline $\begin{array}{l}\text { Przyszła żona } \\
\text { jest: }\end{array}$ & Przykład \\
\hline Kobieca & $\begin{array}{l}\text { Przede wszystkim podobała mi się jako } \\
\text { kobieta. R608, Mężcz., 52, 6 dzieci }\end{array}$ \\
\hline $\begin{array}{l}\text { Odpowiednia } \\
\text { osoba do roz- } \\
\text { mów }\end{array}$ & $\begin{array}{l}\text { Pierwszą rzeczą to było to, że chciało mi } \\
\text { się z tą osobą rozmawiać i rozmawia- } \\
\text { nie dawało mi bardzo dużo satysfakcji. } \\
\text { R3011m, Mężcz., 34, 3 dzieci }\end{array}$ \\
\hline Dobra & $\begin{array}{l}\text { Zwróciłem na nią uwagę, ponieważ od- } \\
\text { powiadała moim wyobrażeniom na te- } \\
\text { mat żony i to że jest dobra. ( ... ) Waż- } \\
\text { ne było to, że moja żona jest dobra i jak } \\
\text { mówiłem spełnia moje oczekiwania, co } \\
\text { do żony, że tak będzie wyglądać. R4010, } \\
\text { Mężcz., 37, 4 dzieci }\end{array}$ \\
\hline
\end{tabular}

Jeśli natomiast chodzi o okres obecny, małżonkowie również dużą rolę przywiązują do życia małżeńskiego. Jest to bardzo ważna dla nich sfera życia, o którą się troszczą i starają się pogłębiać wzajemne relacje, również przez udział w ruchach rodzinnych w Kościele czy warsztatach dla małżonków. Jeden z respondentów mówi, że właśnie pogłębienie wzajemnej relacji w małżeństwie jest dla niego źródłem szczęścia w życiu. 
Ogólnie to ja jestem bardzo szczęśliwy, a to przede wszystkim wynika z rozwoju małżeństwa. Dlatego że matżeństwo dojrzewa. R4010, Męcz., 37, 4 dzieci.

W wypowiedziach badanych przewija się również myśl, że ich małżeństwo nie jest tylko zwykłym ludzkim związkiem, ale jest w nim interwencja Boga, że jest ich powołaniem życiowym. Dlatego też ma tak wielkie znaczenie dla ich życia.

Pan Bóg miał to w swoim planie. R608, Kobieta, 47, 6 dzieci.

Poznaliśmy się w kościele, ja zakochałem się i tak myślimy, że wiara nas połaczyła R301, Mężcz., 44, 3 dzieci.

Osoby biorące udział w badaniu są przekonane o wartości małżeństwa, które jest związkiem trwałym, wyrazem wolnej decyzji małżonków oraz w którym widoczna jest interwencja i błogosławieństwo Boga.

(b) Postawy wobec dzieci

Postawa rodziców wobec dzieci w badanych rodzinach wielodzietnych jest pozytywna, choć wiąże się również z wyrażanym przez respondentów trudem związanym z opieką i wychowaniem dzieci. W wypowiedziach badanych można wyróżnić kilka powtarzających się przekonań odnośnie do wartości dzieci w rodzinie. W tabeli poniżej zostały one zebrane wraz z przykładami wypowiedzi badanych. Każde dziecko jest przede wszystkim widziane jako ogromna, niepowtarzalna wartość, źródło radości i szczęścia, naturalna konsekwencja rozwoju rodziny, zaspokojenie pragnień. Kiedy badani mówią o swoich dzieciach, u wielu widać wzruszenie. 


\begin{tabular}{|c|c|}
\hline & \\
\hline $\begin{array}{l}\text { wartość sama } \\
\text { w sobie, wyjątko- } \\
\text { wość }\end{array}$ & $\begin{array}{l}\text { Pytali się też inni, skąd się to wzięło, } \\
\text { przecież moja mama, jak się urodziła } \\
\text { moja } 2 \text { siostra, to już była patologia. To } \\
\text { chyba z oazy (młodzieżowa wspólnota } \\
\text { religijna), że się zachwyciłam tą Bożą } \\
\text { droga, że każde życie jest ważne, ta hie- } \\
\text { rarchia Boża dla rodziny. R702, Kobieta, } \\
49,7 \text { dzieci } \\
\text { Chociaż to szkoda, że nie mamy więcej. } \\
\text { To (dziecko) każde następne wnosi tak } \\
\text { coś niesamowitego, że człowiek myśli } \\
\text { sobie, co by to było, gdyby go nie było. } \\
\text { R608, Kobieta, } 47,6 \text { dzieci } \\
\text { Ja sobie nie wyobrażam tak, życia takie- } \\
\text { go bez dzieci czy z jednym dzieckiem, } \\
\text { czy bez któregoś z tych naszych różnych } \\
\text { dzieci. Naprawdę, każdy jest inny, każ- } \\
\text { dy ma takie swoje zalety, wady, jakieś } \\
\text { tam do wyprostowania. Dzieciaki takie } \\
\text { szczególne, potrzebne, no nie zastąpione } \\
\text { po prostu (wzruszenie). R409, Kobieta, } \\
37,4 \text { dzieci }\end{array}$ \\
\hline $\begin{array}{l}\text { źródło radości } \\
\text { i szczęścia }\end{array}$ & $\begin{array}{l}\text { Dzieci są rewelacyjne ich pomysły i za- } \\
\text { chowania, powiedzonka, to, co wymy- } \\
\text { ślą. Ja kocham swoje dzieci i wyjecha- } \\
\text { łem, i przez } 5 \text { dni nie widziałem żadnego } \\
\text { z nich, to aż ich szukałem, gdzie dzie- } \\
\text { ci sa, aby się z nimi przywitać. R406, } \\
\text { Mężcz., 39, } 4 \text { dzieci } \\
\text { I wtedy, jak się zakłada rodzinę, masz } \\
\text { męża, to chcesz jeszcze pomnożyć to } \\
\text { szczęście, więc jak jest jeszcze więcej } \\
\text { dzieci, to chcesz pomnożyć to szczęście. } \\
\text { R608, Kobieta, } 47,6 \text { dzieci }\end{array}$ \\
\hline
\end{tabular}




\begin{tabular}{|l|l|}
\hline $\begin{array}{l}\text { konsekwencja } \\
\text { małżeństwa }\end{array}$ & $\begin{array}{l}\text { Nie odkładaliśmy poczęcia dziecka i to } \\
\text { było dla nas normalne, że chcemy mieć } \\
\text { dziecko. R301, Mężcz., 44, 3 dzieci }\end{array}$ \\
\hline $\begin{array}{l}\text { zaspokojenie } \\
\text { pragnienia }\end{array}$ & $\begin{array}{l}\text { Mam dzieci, bo chciałem mieć dzieci. } \\
\text { R407, Mężcz., 38, 4 dzieci }\end{array}$ \\
\hline
\end{tabular}

Kiedy porównuje się przedstawione powyżej przekonania odnośnie do dzieci z przekonaniami podawanymi w literaturze przedmiotu, widać następujące różnice. $\mathrm{Na}$ przykład, młode osoby, które nie mają dzieci lub mają tylko jedno, zamężne lub żyjące w związkach kohabitacyjnych, nie wskazuja że dziecko jest wartością samą w sobie. Natomiast w swoich wypowiedziach mówią o korzyściach związanych z posiadaniem dziecka. Są to: wsparcie dla nich $\mathrm{w}$ podeszłym wieku, ochrona przed pustką czy samotnością lub posiadanie dziecka-spadkobiercy, któremu można zostawić coś w sensie materialnym czy psychologicznym ${ }^{25}$.

(c) Postawy wobec rodziny

Tak jak małżeństwo i dzieci, również rodzina, a więc wspólnota małżonków i dzieci, stanowi dla respondentów bardzo dużą wartość. Jest to widoczne już w wypowiedziach respondentów, kiedy mówią o okresie przedmałżeńskim i przywiązywaniu dużej wagi do wzajemnego poznania się $\mathrm{w}$ tym, co dotyczy rodziny i wyobrażeń o niej.

Dla mnie ważne na początku było, abyśmy dużo rozmawiali, abyśmy wiedzieli, co każdy z nas myśli o małżeństwie, rodzinie, nawet o ewentualnych teściach. R404, Kobieta, 34, 4 dzieci.

Poznanie swojego przyszłego małżonka i przez to dobre przygotowanie się do założenia rodziny ważne było dla $1 / 3$ respondentów. To poznanie jednak w żadnym ba-

25 Por. M. Młynarska, Individual fertility choices in Poland, UKSW, Warszawa 2009 , s. 86. 
danym przypadku nie oznaczało wspólnego zamieszkania czy rozpoczęcia współżycia przed ślubem. Wszyscy badani uważali, że dopiero małżeństwo uprawomocnia współżycie.

W wypowiedziach respondentów można także wyróżnić przedkładanie rodziny nad dbanie o siebie i karierę zawodową. Badani zdają sobie sprawę, że jest to w obecnej kulturze postawa rzadka i często niezrozumiała nawet dla najbliższych.

Taki jestem nierealistyczny, nie myśle o swoim życiu, ale myśle tylko o rodzinie, że mam dzieci i muszę je utrzymać. R404, Mężcz., 39, 4 dzieci.

W ostatniej wypowiedzi pojawia się przekonanie o konieczności zapewnienia przez ojca bytu materialnego rodzinie. Taką postawę reprezentuje $2 / 3$ badanych. Badani mężczyźni zdają sobie sprawę, że kobiety wykonują bardzo ciężką pracę przy opiece i wychowaniu kilkorga małych dzieci i nie mają możliwości podejmowania jeszcze dodatkowej pracy zarobkowej. Szczególnie w rodzinach o dużej dzietności, kiedy kolejne małe dzieci są przez wiele lat $\mathrm{w}$ rodzinie, małżonkowie $\mathrm{w}$ pewnym momencie trwania związku podejmują decyzję, że żona zostanie w domu przy dzieciach, a ojcowie mają zadbać o materialne potrzeby rodziny. W dźwiganiu tej odpowiedzialności zarówno u młodszych, jak i u starszych stażem ojców bardzo znaczącą rolę odgrywa wiara. Mają przekonanie, że ich starania są wspomagane przez Boga i On troszczy się także o byt ich rodziny.

W dniu, kiedy się zaręczyłem straciłem moja pierwsza pracę. Potem znalazłem prace $w$ Warszawie, taki staż. Po tym stażu doszło do poczecia (pierwszego dziecka) i szybko awansowałem. Dopiero straciłem ta prace przed miesiacem. To jest tak, że wraz ze wzrostem liczby dzieci rosła nam liczba pieniędzy. Ja ciagle awansowałem aż do dosyć wysokiego stanowiska. Statystycznie rzecz biorac, to nie tak, że mieliśmy więcej środków i decydo- 
waliśmy się na kolejne dziecko, nie, mieliśmy kolejne dziecko $i$ wtedy nasza sytuacja się poprawiała. Zgodnie z kaszubskim przysłowiem "Bóg da dzień, Bóg da radość". R4010, Mężcz., 37, 4 dzieci.

W ostatniej wypowiedzi pojawia się przekonanie, że przyjęcie kolejnego dziecka sprawia, że pojawiają się nowe możliwości, aby można było utrzymać dzieci. Rodzice są przekonani, że w swojej trosce o zapewnienie bytu materialnego są wspomagani przez Boga.

Poczucie odpowiedzialności u ojców za rodzinę wpływa na decyzje dotyczące wyboru pracy. W jednej z rodzin mężczyzna rezygnuje z kariery naukowej, aby przejść do pracy w biznesie i uzyskiwać lepszy dochód. Sam dochód nie jest jednak najważniejszym celem, ponieważ badany potrafi również zrezygnować z lepiej płatnej pracy, aby być więcej z dziećmi i z rodziną.

(..) musiał zrezygnować z pracy na uczelni i zatrudnić się w firmie. Bardzo dużo pracowat, wracat późno. Tak, że prawie wcale nie widział dzieci. Myślat, że chociaż w wakacje będzie mógł sobie zrekompensować, odebrać nadgodziny, ale absolutnie tak nie było. Wtedy zacząt szukać, powiedziat, że mu zależy na rodzinie i chce widzieć jak dzieci dorastaja. R404, Kobieta, 34, 4 dzieci.

Troska o dobre wychowanie dzieci jest charakterystyczna dla badanej grupy. Cel wychowawczy, jaki stawiają sobie rodzice $\mathrm{w}$ rodzinach wielodzietnych, to wychowanie dziecka na osobę, która podejmuje w życiu wyzwania, jest wewnętrznie spójna, dojrzała oraz dobra, uczciwa i wierząca.

Widać to nawet w tych rodzinach, w których dochód jest bardzo wysoki i stać byłoby rodziców na dobra materialne dla czwórki dzieci czy też zapewnienie im bardzo dobrego wykształcenia. Cele wychowawcze są podobne. 
Mi to naprawde na tym tylko zależy, naprawde nie musza zostać politykami. (...) Kompletnie nie, niech sobie będa hydraulikami, ale niech będa ludźmi dojrzałymi, ukształtowanymi wewnętrznie, takimi spójnymi osobami, które wiedza, co jest najważniejsze. R4010, Kobieta, 36, 4 dzieci.

Są to cele wychowawcze, które nie wymagają dużych nakładów pieniężnych, ale stałego oddziaływania wychowawczego. Dlatego też, dla badanych rodzin charakterystyczne jest nastawienie kobiet na zajmowanie się osobiście dziećmi, szczególnie w pierwszych latach życia. Kobiety opiekę i wychowanie ich stawiają na pierwszym miejscu. Jeśli nawet rozważają powrót do pracy, to chciałyby pracować w mniejszym wymiarze godzin, aby móc zajmować się dziećmi. Najczęściej rodzina staje się dla nich ważniejsza niż rozwój zawodowy. Postawy dotyczące osobistej opieki nad dziećmi, jako najlepszej formy wychowania, kształtują się u kobiet w miarę powiększania się rodziny i nierzadko są one wspierane przez autorytety moralne. Jedna z kobiet, wspominając swoje spotkanie z papieżem, tak je opisuje:

Mieliśmy takie szczęście, że byliśmy u Ojca Świętego (Jana Pawła II) (...) Tak napisaliśmy normalnie list do Watykanu. Potem byliśmy z trójka dzieci, jak się urodziło trzecie dziecko, dziewczynka. Mieliśmy 4 latkę, 2 latka i 3 tygodniowa córkę. Jak Papież nas zobaczyt, to pierwsze słowo, jakie powiedział to było „O mama..."(śmiech) I to tak mi utkwiło, że to jest właśnie moje zadanie - mama. R608, Kobieta, 47, 6 dzieci.

Nastawienie do opieki instytucjonalnej dla dzieci w wieku do 3 lat jest, poza jednym wyjątkiem, negatywne. $W$ większości rodzin korzystanie $z$ opieki instytucjonalnej jest akceptowane dopiero od przedszkola. Dbałość i troska o dzieci w rodzinach wielodzietnych potwierdzona jest również innymi badaniami. 
(d) Postawy wobec wielodzietności

Chęć posiadania dużej rodziny wśród badanych krystalizowała się $\mathrm{w}$ różnych okresach ich życia. U kilku respondentek marzenie o dużej rodzinie pochodziło już z czasów dzieciństwa czy wczesnej młodości. Inne osoby określały swoje preferencje co do wielkości rodziny w okresie narzeczeńskim, jeszcze inni w czasie trwania życia rodzinnego.

Wartości, jakie przypisywano dużej rodzinie, można podzielić na trzy grupy. Po pierwsze, wartość dużej rodziny jest związana z tym, co zapewnia ona rodzicom i dzieciom. Po drugie, związana jest z realizacją tego stanu, który jest bliski poprzez rodzinę pochodzenia lub wynika z osobistych pragnień, dlatego też jest przez badanych pożądany. Do trzeciego typu można zaliczyć przeświadczenie, że wielodzietność jest wartościa, ponieważ jest akceptacją daru życia dziecka i przyjęciem tego, co Pan Bóg daje rodzinie.

Należy podkreślić, że wszystkie te trzy wymiary nakładają się w postawach osób badanych i nie jest tak, że respondent pragnie dużej rodziny tylko ze względu na jeden z trzech wymienionych rodzajów wartości. Przede wszystkim, jak wspomniano wyżej, małżonkowie uważają że duża rodzina jest miejscem, gdzie potencjalnie jej członkom może być lepiej niż w rodzinie mniejszej.

Zawsze miałam takie intuicyjne przeświadczenie, że chciatabym mieć duża rodzine, że duża rodzina jest dobra $i$ dla rodziców i dla dzieci między soba i dla rodziców i dzieci. Duża rodzina jest fajna. R3011, Kobieta, 33 lata 3 dzieci.

Następne dwie wypowiedzi bardziej mówią o lepszych warunkach rozwoju dla dzieci w dużej rodzinie. Pierwszy respondent wskazuje na trudności, jakie moga mieć jedynacy w związku z brakiem braci i sióstr czy ciągłym przebywaniem w obecności osób dorosłych.

Ja zawsze chciałem mieć dzieci więcej niż jedno, no tak jest, bo jedno to jest mordega. Jak ja widze nieraz: te mamy, tatusio- 
wie skacza koło tego jednego. Ani mu nie dadza tego, co rówieśnik, ani nie nabiora właściwych relacji, to jest naprawdę zupetnie co innego. Nie wejda w relacje z siostra, bratem, a co innego jest z przytakującym starszym. R407, Mężcz., 38, 4 dzieci.

Więcej rodzeństwa to również możliwość nauczenia się relacji rówieśniczych i nabycie umiejętności dla lepszego służenia innym ludziom. Przebywanie wśród różnych dzieci stwarza możliwość poznania zarówno silnych, jak i słabych stron innych osób, a przez to lepszego przygotowania się do życia małżeńskiego, które wymaga akceptacji drugiej osoby również z jej niedoskonałościami.

Tak jak jest u nas tych dzieci 6, to te dzieci wchodza w świat, to naucza się stużyć innym, to wchodza jeszcze w świat z takim bagażem (...) One po prostu nauczyty się relacji z ludźmi w różnym wieku, o różnej płci, o różnych charakterach i maja już tyle. Jedynak ma jedna mame i jednego tatę, tu ma jedna płeć, druga płeć i ma tylko charakter mamy i taty. A dziecko ma młodsze rodzeństwo i starsze rodzeństwo, siostre, która jest tam choleryczka i brata, który coś tam. I tego się uczy na co dzień. Ono będzie umieć lepiej innym stużyć niż dziecko jedynak. Będzie bardziej przygotowane do różnych sytuacji. Też wydaje mi się, że będzie dzieciom $z$ takich dużych rodzin łatwiej w małżeństwach. Bo one tyle się nauczyty tych sytuacji ludzkich, że one sobie poradza z tym mężem, żona, którzy oczywiście po ślubie nie okaża się tak idealni, jak to było planowane przed ślubem i trzeba będzie umieć z ta osoba żyć. A skoro przez te 18 czy 20 lat w rodzeństwie stale żyło się z tymi osobami, które nie do końca były takie, jakby się chciało, jaki jest to dla dzieciaków bagaż. R608, Kobieta, 47, 6 dzieci.

Ponieważ większość respondentów, tzn. 15 osób, pochodziło z rodzin wielodzietnych, posiadanie większej liczby dzieci było dla nich czymś naturalnym. Raczej nie wyobrażali sobie, że mogłoby być inaczej. Nawet, jeśli w czasach młodości między rodzeństwem istniały konflikty, obecnie dostrzegają wartość obecności sióstr i braci.

Na pewno nie mieliśmy takiego podejścia, że to będzie tylko jedno, bo to trudne czasy, bo coś tam. Nie, nigdy się w nas coś takiego nie pojawiło. Raczej dobrze jest mieć duża rodzine, żeby 
nasze dzieci nie były samotne. Té̇ tak w swoim życiu doświadczyłam dużej radości z posiadania rodzeństwa. Chcieliśmy, aby nasze dzieci też ta nasza radość miaty. R409, Kobieta, 37, 4 dzieci.

Dla trzech respondentek duża rodzina była realizacją ich marzeń z dzieciństwa czy młodości. Dwie z nich pochodziły z rodzin, gdzie była dwójka dzieci, a jedna z rodziny z czwórką dzieci. W każdym jednak przypadku kobiety marzyły, aby mieć więcej dzieci niż mieli ich rodzice.

Miałam tylko jedna siostre, ale bardzo chciałam mieć rodzeństwo. Pamiętam, że nieraz zasypiałam z takim pragnieniem, że dałabym sobie rękę obciać, żeby tylko mama dała mi jeszcze rodzeństwo i bardzo namawiałam rodziców, ale nie udało mi się. R405, Kobieta, 53, 4 dzieci.

Zawsze chciałam mieć więcej dzieci. Pamiętam, że w okresie liceum chciałam mieć sześcioro - 4 chłopców i 2 dziewczynki. Zawsze mi się wydawało, że tych chłopców musi być więcej, tak z rodziny. A mam 4 dziewczynki i 2 chłopców. Ale to, tak zawsze było, że to dużo. Pamiętam, że w dzieciństwie tata wielokrotnie nam czytał taka bardzo fajna opowieść Zofii Rogoszównej. Powiastka była pisana wierszem dla dzieci, której głównymi bohaterami była rodzina Państwa Tygodników. Pan Tydzień miat żone Niedziele i mieli sześcioro dzieci: Poniedziatek itd. Tam był taki wierszyk "Dziatek dat im sześcioro, nie za wiele, nie za mało, córki wdzięk swój z matki biora, chłopcy zuchy gęba cała". I jakoś mi utkwiło, że sześcioro to jakoś dobrze. R608, Kobieta, 47, 6 dzieci.

Rodzina jest także miejscem przyjęcia każdego dziecka, które się pocznie w związku. Ta myśl przewija się w wielu wypowiedziach, szczególnie dotyczących podejścia do prokreacji. Należy podkreślić, że w omawianym kontekście wartościowania wielodzietności jest ona poprzedzająca samą dzietność. Najpierw małżonkowie zakładaja, że przyjmą każde dziecko, którym zostaną obdarzeni, a potem stają się rodziną wielodzietną.

O dzieciach też rozmawialiśmy. Nie byliśmy na pewno zamknięci na życie, jakby tak pamiętam 3-4 dzieci. Ale to na zasadzie, co Pan Bóg da, jak tam będzie, tak będzie. R409, Kobieta, 37, 4 dzieci. 
Podsumowując - pozytywna postawa wobec wielodzietności wynika z trzech przesłanek. Po pierwsze, z przekonania, że rodzina wielodzietna jest dobra dla rodziców i dzieci. Po drugie zapewnia, szczególnie dzieciom, zdobycie umiejętności budowania relacji z innymi ludźmi. Ponadto, dzięki rodzeństwu dzieci w dorosłym życiu nie są osamotnione. Rodzeństwo może być dla nich oparciem i źródłem radości. Duża rodzina, dla małżonków, którzy pochodzą z rodzin wielodzietnych, jest strukturą znana, bliską i z tego powodu chcą ją realizować w swoim życiu. Dla niektórych respondentów jest spełnieniem ich marzeń z dzieciństwa.

(e) Przekonania i postawy odnośnie do prokreacji

- kiedy pierwsze dziecko?

Jeśli chodzi o czas narodzin pierwszego dziecka można wyróżnić dwie grupy wśród badanych. Pierwsza z nich pragnęła poczęcia dziecka zaraz po zawarciu związku małżeńskiego. Małżonkowie byli przekonani, że dziecko jest wartościa, i chcieli, żeby ono się pojawiło w ich związku jak najszybciej. W tej grupie znajdują się również dwa małżeństwa, które pragnęły dziecka, ale ze względów zdrowotnych musiały odłożyć jego poczęcie. Druga postawa charakteryzuje się odkładaniem w czasie poczęcia dziecka - z różnych powodów. Powodami, które pojawiły się w wypowiedziach badanych, była chęć pogłębienia relacji między małżonkami, gdy byli jeszcze małżeństwem bezdzietnym, oraz ocena sytuacji materialnej jako niesprzyjającej dla wychowania dziecka. 
Tabela 5. Postawy wobec czasu poczęcia pierwszego dziecka

\begin{tabular}{|c|c|c|c|c|}
\hline \multicolumn{2}{|c|}{ nieograniczanie poczęcia } & \multicolumn{2}{c|}{ odkładanie poczęcia } \\
\hline zajście & niepłod- & trudna & chęć bycia & ocena \\
w ciążę & ność pary & sytuacja & przez & warunków \\
& przez 5 lat & zdrowot- & pewien & materialnych \\
& & na, ko- & czas mał- & jako niewy- \\
& & nieczność & żeństwem & starczających \\
& odłożenia & bezdziet- & na przyjęcie \\
& & poczęcia & nym & dziecka \\
& & & & \\
& & & & \\
\end{tabular}

Spośród badanych dwunastu par 10, czyli zdecydowana większość, reprezentowała postawę otwarcia na dziecko zaraz po zawarciu małżeństwa. Wśród nich jedno małżeństwo, ze względu na niepłodność pary, nie miało dzieci przez 5 lat po ślubie, a dwa małżeństwa musiały odłożyć poczęcie ze względu na sytuację zdrowotną kobiety.

Jedno małżeństwo odkładało decyzję o poczęciu dziecka, tak jak wspomniano wyżej, ze względu na chęć pogłębienia relacji między małżonkami. Wynikało to z ich przekonania, że ten rok bez dziecka będzie dobry dla przyszłego życia rodziny.

Po ślubie poczekaliśmy rok. Gdzieś styszeliśmy i wydawało nam się to fajne i madre, ¿̇e dobrze by było oczywiście, jeśli bytoby to możliwe, żeby dać sobie chwile czasu jako małżeństwu. Aby nacieszyć się soba, poznać się. R3011, Kobieta, 33 lata 3 dzieci.

Jedno małżeństwo odkładało decyzję o urodzeniu pierwszego dziecka ze względu na niepewną sytuację ekonomiczną. Zdecydowali się nie odkładać ślubu, ale poczekać z poczęciem dziecka.

Wiedział (mą̇), że nie mamy mieszkania, nie mamy pracy, to nie jest dobry moment na to, żeby mieć dzieci. To też przegadaliśmy, ̇̇e: "Kochanie nie będziemy mieć dzieci w pierwszym roku naszego małżeństwa. Musimy to zaakceptować, musimy to 
Współczesna sytuacja demograficzna w Polsce

odłożyć świadomie, skoro nasza sytuacja jest niejasna, niepewna". Mój maż̇ o dziwo powiedziat: "To się tak da?". Świadomy był cyklu płodności i tak dalej, ale tak założyt, że małżeństwo to zaraz dzieci. W zwiazku z tym pierwsze dziecko urodzito nam się dwa lata po ślubie. R4010, Kobieta, 36, 4 dzieci.

W tym miejscu należy zaznaczyć, że wszystkie badane pary miały pozytywny stosunek do naturalnej metody planowania poczęć polegającej na obserwacji śluzu i mierzeniu temperatury lub obserwowaniu tylko jednego z wymienionych wskaźników płodności. Jedna kobieta wspomina, że przekonał ją do niej jej przyszły mąż. Sama, mimo studiów medycznych, była raczej negatywnie nastawiono do tej metody, uważając, że jest ona nieskuteczna.

Nie, nie stosowaliśmy (antykoncepcji), choć też to była kwestia dyskusyjne, bo ja, jakby to powiedzieć, nie czułam dokładnie, nie rozumiałam można powiedzieć, nie czułam, dlaczego te naturalne metody sa tak bardzo pożadane, a te sztuczne nie. To było dla mnie zupetnie niezrozumiałe. Trzeba powiedzieć uczciwie, że studia medyczne w ogóle nie przygotowuja do tego tematu $i$ nie ucza tych metod naturalnych. Choćby lekarze byli chociaż jakoś douczeni, kompletnie nie. Nie daja kompletnie żadnych podstaw w tym kierunku, wręcz przeciwnie, wmawiaja ludziom, że to nie działa. To mój mąż przewalczyt. W pewnym momencie powiedział mi: "Stuchaj, tak nie będzie. Masz tu "Miłość i odpowiedzialność" (ksiażka K. Wojtyły). Masz to przeczytać". Ja to przeczytałam i stwierdziłam: "Dobrze kochanie, niech tak będzie". W narzeczeństwie uczyłam się tych metod, więc jak wstępowaliśmy w zwiąek matżeński, to mieliśmy wszystko jak na talerzu. Byliśmy jakoś przygotowani, aby jakoś je wdrażać. To było tak $i$ to było tak dla mnie naturalne. Mimo tego, że byłam wiele lat w oazie (młodzieżowa wspólnota religijna), nie czułam do końca tej seksualności, dlaczego tak powinno być, ale nigdy nie stosowaliśmy (antykoncepcji). Wręcz przyszedł taki czas, że niczego nie stosowaliśmy i jakaś taka otwartość, że to wszystko Pan Bóg poprowadzi, że będzie dobrze. R4010, Kobieta, 36, 4 dzieci.

Stosowanie naturalnej metody przez respondentów wynikało z przekonania, że jest ona zgodna z wyznawa- 


\section{Część I}

Współczesna sytuacja demograficzna w Polsce

nymi wartościami oraz buduje dobre relacje małżeńskie pełne szacunku dla współmałżonka i zapobiega jego instrumentalnemu traktowaniu. Prowadzi również do odpowiedzialności małżonków za siebie i za poczęte dziecko, i jest po prostu zdrowa.

- postawa wobec narodzin pierwszego i kolejnych dzieci

Wszystkie badane osoby i pary miały pozytywne nastawienie do posiadania dzieci, również te, które odkładały decyzję o poczęciu. Należy zaznaczyć, że wśród badanych odraczanie poczęcia nie trwało dłużej niż 1 rok. W związku z tym, postawa wobec pierwszego dziecka była jak najbardziej pozytywna. Zmiany nastawienia wobec planów co do dalszej prokreacji miały przede wszystkim swoje przyczyny w kondycji zdrowotnej matek, w wyczerpaniu fizycznym lub psychicznym, w trudnych warunkach mieszkaniowych i ekonomicznych.

Badani uważają, że zmiany $\mathrm{w}$ rodzinie, które zostały wywołane przez pojawienie się pierwszego dziecka, są bardzo duże. Są one jednak przyjmowane jako rzecz naturalna dla kształtowania się rodziny. Małżonkowie nie przerażają się nową sytuacją i starają się jej sprostać. Nowi ojcowie widza, że trzeba od nowa zorganizować życie domowe, z pewnych rzeczy zrezygnować. Matki podejmują opiekę nad dzieckiem, nieraz jak walkę. Część kobiet, mimo wzmożonego wysiłku, odczuwała radość, inne przeżywały depresję czy też okres nieradzenia sobie, totalnego chaosu. Reakcje te są podobne jak w grupie rodzin małodzietnych, z tą różnica, że trudności nie prowadzą do zamknięcia się na kolejne dzieci.

Oczywiście świat się do góry nogami wywrócił, wszystko zaczęło się kręcić wokół dziecka. Ale przyjęliśmy to jako normalne, że taka ma być kolei rzeczy i musieliśmy sobie to poukładać, poukładać nasze odpowiedzialności. Jak to jest? Kto zostaje w domu? Kto pracuje? R301, Mężcz., 44, 3 dzieci.

Przychodzenie na świat kolejnych dzieci nie wprowadzało już tak wielkich zmian. Małżonkowie zaczynają się 
przyzwyczajać do nowych obowiązków i zadań. Przy następnych dzieciach nabierają coraz większej wprawy w opiece nad małym dzieckiem i akceptują zmiany, jakie za sobą pociąga opieka nad nimi.

Dla mnie duża zmiana było pierwsze dziecko i drugie w takim patrzeniu na rodzinne życie. Każde kolejne już nie. Przy pierwszym wszystko kręci się wokoło tego jednego dziecka, wszystko musi być zrobione na tip top, wszystko kręci się wokót tego dziecka. Przy 2 już się nie da tak wszystkiego trzymać $i$ człowiek się przyzwyczaja, i przy 3 jest łatwiej. To pierwsze

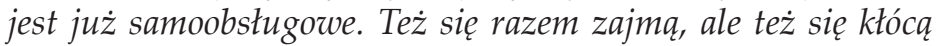
bardziej. R404, Mężcz., 39, 4 dzieci.

We wszystkich rodzinach, poza jedną, pojawiają się okresy, kiedy małżonkowie unikają poczęcia kolejnego dziecka. Wynika to nie ze zmiany postawy wobec dzietności, ale - określanego w teorii I. Ajzena - braku poczucia kontroli. Na przykład, ze złej sytuacji mieszkaniowej rodziny lub problemów zdrowotnych związanych z ciążą lub porodem.

$\mathrm{W}$ jednej $\mathrm{z}$ rodzin odkładanie poczęcia następuje po urodzeniu pierwszego dziecka, kiedy ze względu na trudną sytuację materialną małżonkowie starają się przez 5 lat, aby nie doszło do poczęcia. Kiedy pojawia się perspektywa wynajęcia mieszkania, małżonkowie otwierają się na następne dzieci. Ich obecna dzietność wynosi 7 dzieci.

W trzech badanych rodzinach miała miejsce sytuacja poczęcia dziecka mimo unikania poczęcia przez parę. W postawach badanych rodziców miał miejsce proces przejścia od niechęci do akceptacji i radości. Można to przedstawić schematycznie:

\section{Rozpacz, niechęć, lęk} obawa Akceptacja, Radość

Po jednej stronie jest rozpacz i niechęć, po drugiej przyjęcie dziecka z radością. Między tymi skrajnymi reakcjami jest jeszcze akceptacja połączona z obawami. Należy zaznaczyć, że negatywne postawy rodziców ulegają zmia- 
nom. Na początku dominuje niechęć do poczętego dziecka, po pewnym czasie pojawia się akceptacja, ale związana jeszcze z obawami. W miarę upływu czasu, nawet jeszcze przed momentem porodu, przychodzi radość.

Dwie spośród badanych rodzin znalazły się w sytuacji, kiedy po podjęciu decyzji o zakończeniu prokreacji miało miejsce poczęcie kolejnego dziecka. Nieplanowane poczęcie zostało przyjęte bardzo źle szczególnie przez matki. Nastąpiła jednak zmiana ich postaw i nowonarodzone dzieci stały się dla kobiet źródłem dumy i radości. U pierwszej respondentki obawa i lęk przechodzi w zaufanie Bogu. Pokazuje to charakterystyczne przekonanie badanych par, które z różnym natężeniem występuje u respondentów, że dziecko jest darem od Boga i On panuje również nad całą rzeczywistością.

- postawa wobec planowania jeszcze kolejnych dzieci

Ponieważ połowa kobiet, które brały udział w badaniu, przekroczyła 47. rok życia, rodziny te nie przewidują posiadania kolejnych dzieci w przyszłości. W czterech rodzinach z tej grupy, decyzja o zakończeniu prokreacji została podjęta już wcześniej w związku z różnymi sytuacjami, które nie dawały badanym subiektywnego poczucia kontroli. Natomiast w dwóch kolejnych rodzinach zakończenie prokreacji wynikało z naturalnego cyklu płodności kobiety. Trzeba zauważyć, że są to rodziny o dużej dzietności sześcioro i siedmioro dzieci.

Jeśli chodzi o młodsze pokolenie, czyli rodziny, które w przyszłości mogłyby mieć więcej dzieci, to dwie spośród badanych rodzin, które mają dochody wystarczające na utrzymanie rodziny przez męża, planują posiadanie kolejnych dzieci po okresie przerwy.

Na pewno nie wykluczam, wydaje mi się naturalne, że będziemy za jakiś czas mieli więcej dzieci. Ale nie zdziwiłbym się, jakbyśmy pozostali przy 3 dzieci. R3011m, Mężcz., 34, 3 dzieci.

Dwie spośród badanych rodzin chciałyby mieć więcej dzieci, ale obecnie - ze względu na ciężką sytuację mate- 
rialną - oceniają że nie dałyby rady utrzymać większej liczby dzieci.

Ja jeszcze moge mieć 10 dzieci pod warunkiem, że rzad nie będzie mi siadat na plecy. Inaczej ja nie dam rady $i$ juz dzisiaj nie daje rady, ale to nie ja przeholowałem. W zesztym roku, jak zwiększyli podatki to 2,5 mld więcej wyciagnęli od rodzin $i$ dzieci. A rząd mówi, że dali 5 mld, a to dzieci kupuja dzieciom. R407, Mężcz., 38, 4 dzieci.

W kolejnych dwóch badanych młodszych rodzinach wpływ na decyzję prokreacyjną ma u jednych małżonków chęć powrotu kobiety do aktywności zawodowej, w drugiej rodzinie natomiast odgrywają rolę dwa czynniki. Są to: trudna sytuacja materialna i problemy ze zdrowiem (każde z czworga dzieci urodziło się przez cięcie cesarskie).

Charakterystyczne dla badanej grupy rodzin jest to, że choć nie planują już kolejnych dzieci, to nastawienie jest takie, że przyjęliby następne dziecko, jeśliby się poczęło. Życie dziecka jest - zarówno dla badanych kobiet, jak i mężczyzn - ogromną wartością. Stąd też negatywny stosunek wszystkich respondentów do aborcji.

Podsumowując, można powiedzieć, że decyzje tych badanych, którzy ze względu na możliwości biologiczne mogliby mieć dzieci, zależą od czynników związanych z poczuciem kontroli według Teorii Planowanego Zachowania. Nie jest to jednak tematem niniejszego artykułu.

\section{Podsumowanie}

Z przeprowadzonych badań wynika, że posiadanie większej liczby dzieci w rodzinach, gdzie małżonkowie świadomie wybierają model rodziny wielodzietnej oraz mają wyższe wykształcenie i zamieszkują w miastach lub aglomeracjach miejskich, koreluje $\mathrm{z}$ następującymi przekonaniami i postawami:

- postrzeganie małżeństwa jako wyrazu miłości i wolnej decyzji małżonków, związku trwałego i nierozerwalnego, w którym działa Bóg;

- patrzenie na dziecko, przede wszystkim, jako na war- 
tość samą w sobie, źródło radości i szczęścia, naturalną konsekwencję tworzenia rodziny oraz rezultat decyzji małżonków;

- uważanie rodziny za bardzo dużą wartość - rodzina jest ważniejsza niż kariera, pieniądze czy dbanie o siebie;

- podział ról w rodzinach polega na wzajemnym uzupełnianiu się: badani ojcowie uważaja, że na nich spoczywa główna odpowiedzialność za zaspokojenie potrzeb bytowych rodziny, a w wypełnianiu tego zadania są wspomagani przez Boga; matki są w większości przekonane, że dla prawidłowego rozwoju dzieci i relacji $\mathrm{w}$ rodzinie niezbędna jest ich osobista opieka nad dziećmi w domu, przede wszystkim, kiedy są one w wieku do 3 lat;

- cele wychowawcze stawiane przez badanych w wychowaniu dzieci są skierowane na ukształtowanie człowieka spójnego wewnętrznie, szczęśliwego, dobrego i wierzącego;

- rodzina wielodzietna jest postrzegana jako najlepsze środowisko do wychowania dzieci i bycia rodzicami oraz miejsce akceptacji każdego dziecka poczętego jako daru życia pochodzącego od Boga; jest również formą życia rodzinnego znaną większości rodziców, ponieważ pochodzą oni z rodzin wielodzietnych;

- małżonkowie w zdecydowanej większości nie odkładają po ślubie decyzji o poczęciu pierwszego dziecka;

- trudności związane z opieką nad małym dzieckiem uważają za wyzwania, które należy podjąć;

- do dalszej prokreacji mają nastawienie pozytywne, choć zmienia się ono pod wpływem czynników zdrowotnych, ekonomicznych i trudności dnia codziennego i prowadzi do decyzji o odłożeniu lub zakończeniu prokreacji;

- w parach, w których po decyzji zakończenia prokreacji następuje kolejne poczęcie, stosunek do tych nieplanowanych ciąż zmienia się $\mathrm{w}$ czasie ich trwania; jest to proces przechodzenia od niechęci i lęku przez ak- 
ceptację i zaufanie Bogu do radości przy narodzinach dziecka;

- do aborcji stosunek wszystkich małżonków jest zdecydowanie negatywny, dlatego pary, które już nie planują więcej dzieci uważaja, że jeśli pocznie się kolejne dziecko zostanie ono przyjęte;

- współżycie seksualne jest akceptowane po zawarciu małżeństwa i w jego ramach;

- wszystkie badane pary albo nie stosują żadnej metody kontroli urodzeń, albo naturalne metody regulacji poczęć polegające na obserwacji cyklu płodności kobiety przez kontrolę temperatury lub śluzu;

- odkładanie poczęcia lub zakończenie prokreacji jest uwarunkowane przede wszystkim czynnikami związanymi z poczuciem kontroli według teorii I. Ajzena.

Zastosowanie badania jakościowego do poznania przekonań i postaw rodziców świadomie podejmujących decyzje o wielodzietności pozwoliło nie tylko na wyodrębnienie poszczególnych czynników, ale także na uchwycenie procesów, jakie mają miejsce przy podejmowaniu decyzji prokreacyjnych. W sposób całościowy zostaną one zrekonstruowane $\mathrm{w}$ dalszej części badania, po opracowaniu następnych dwóch grup czynników, to jest: grupy czynników odnoszących się do subiektywnej normy i drugiej grupy czynników kształtujących poczucie kontroli. Należałoby również uzyskane wyniki odnieść do większej zbiorowości i sprawdzić, jakie zachodzą tu korelacje. Drugi etap pracy będzie polegał na analizie statystycznej badań przeprowadzonych na większej zbiorowości.

Wyniki uzyskane w badaniu rodziców mających większą liczbę dzieci są zbieżne z już wcześniej odkrytymi zależnościami. Posiadanie większej liczby potomstwa koreluje pozytywnie $\mathrm{z}$ pochodzeniem małżonków z rodzin 
wielodzietnych, religijnością ${ }^{26}$, negatywnym stosunkiem do aborcji ${ }^{27} \mathrm{i}$ antykoncepcji ${ }^{28}$. Potwierdzają również hipotezę sformułowaną przez profesora W. Fijałkowskiego, że naturalna regulacja poczęć wyzwala od lęku przed dziećmi i przysposabia małżonków do życzliwego ich przyjęcia ${ }^{29}$. Z przeprowadzonego badania wynika jednoznacznie, że wielodzietność wśród osób posiadających wyższe wykształcenie i zamieszkujących aglomeracje miejskie jest powiązana ze stosowaniem naturalnej metody regulacji poczęć. Dalszych badań wymaga, jakie jest to powiązanie. Wielodzietność zmienia również nastawienie matek odnośnie do pracy zawodowej. Preferują one pracę na część etatu lub chcą całkowicie poświecić swój czas rodzinie ${ }^{30}$.

Rozpoczynając badanie, nie przypuszczałam, że przekonania rodziców z rodzin wielodzietnych będą w dużym stopniu zbieżne $\mathrm{z}$ wizją małżeństwa i rodziny przedstawioną w dokumentach Kościoła katolickiego. W Katechizmie Kościoła katolickiego małżeństwo określane jest jako przymierze, przez które mężczyzna i kobieta tworzą ze sobą wspólnotę całego życia ${ }^{31}$, związek nierozerwalny ${ }^{32}$, miejsce miłości mężczyzny i kobiety, gdzie w szczególny sposób działa Bóg33. Małżeński węzeł jest wyłączny i nie może być nigdy rozwiązany, a do jego zawarcia potrzebna jest wolna zgoda przyszłych małżonków ${ }^{34}$. W encyklice Humane vite stwierdza się, że ci małżonkowie realizują roztropne rodzicielstwo, którzy, kierując się roztropnym namysłem i wielkodusznościa, decydują się na przyjęcie

\footnotetext{
26 Por. F. Adamski, Rodzina między sacrum a profanum, Pallottinum, Poznań 1987, s. 114.

27 Por. W. Fijałkowski, Ekologia prokreacji, „Studia Demograficzne” (1986), nr 3/85, s. $19-20$.

28 Por. F. Adamski, Rodzina między sacrum a profanum, dz. cyt., s. 116.

29 W. Fijałkowski, Ekologia prokreacji, dz. cyt., s. 12.

30 Por. What Mothers to Mothers in Europe - survey of mothers in Europe 2011 results, MMM Europe (Mouvment Mondial des Meres-Europe) 2011.

31 Por. Katechizm Kościoła katolickiego, Pallotinum, Poznań 1994, nr 1601.

32 Por. tamże, nr 1614.

33 Por. tamże, nr 1604.

34 Por. tamże, nr 1638,1639,1640.
} 
liczniejszego potomstwa ${ }^{35}$. W tym dokumencie znajduje się również zakaz przerywania ciąży i stosowania antykoncepcji ${ }^{36}$.

Wynik przeprowadzonego badania pokazuje wage inicjatyw na rzecz małżeństwa i rodziny podejmowanych przez Kościół w obliczu głębokiego kryzysu demograficznego w Polsce. Należy tu zwrócić uwage przede wszystkim na znaczenie takich inicjatyw, jak:

1. Przygotowanie młodzieży do małżeństwa i założenia rodziny poprzez katechezę szkolna, wspólnoty religijne i kursy przedmałżeńskie. (Wpływ kursów przedmałżeńskich na postawy rodzicielskie i pozytywny stosunek do wielodzietności pokazały badania profesora F. Adamskiego ${ }^{37}$.).

2. Nauczanie Kościoła związane z trwałością i nierozerwalnością małżeństwa. Stosowanie tej zasady w praktyce daje małżonkom poczucie bezpieczeństwa przy podejmowaniu decyzji prokreacyjnych.

3. Wspieranie rodziców w pogłębianiu ich relacji małżeńskich i w zadaniach wychowawczych.

4. Dowartościowanie roli matki zajmującej się osobiście opieką i wychowaniem dzieci. Pomaga to matkom zrezygnować z pracy zawodowej na rzecz wychowania większej liczby dzieci.

5. Wskazywanie na odpowiedzialność ojców za byt rodziny i kształtowanie w nich zaufania do Boga.

6. Wspieranie w akceptacji przez rodziców każdego poczętego dziecka, szczególnie ciąż niezamierzonych.

7. Prowadzenie kursów naturalnego planowania rodziny. Stosowanie naturalnej metody regulacji poczęć sprzyja postawom rodzicielskim ${ }^{38}$.

8. Pomoc materialna wielodzietnym rodzinom.

\footnotetext{
35 Por. Paweł IV, Encyklika Humane vite, Instytut Wydawniczy PAX, Warszawa 1981, nr 10.

36 Por. tamże, nr 14.

37 Por. F. Adamski, Rodzina między sacrum a profanum, dz. cyt., s. 116.

38 Por. W. Fijałkowski, Ekologia prokreacji, dz. cyt., s. 12.
} 
Jak zaznaczono na początku pracy, przedstawione rezultaty badania stanowią jedynie wycinek całego procesu, jakim jest dochodzenie do czynników wpływających na zachowania prokreacyjne skutkujące wielodzietnością. Zbadanie dalszych czynników, należących do dwóch pozostałych grup według Teorii Planowanego Zachowania, tzn. subiektywnych norm i poczucia kontroli, wymaga dalszych prac analitycznych. Powinny one pozwolić na całościową rekonstrukcję procesu zachowań prokreacyjnych w badanych rodzinach wielodzietnych i wyodrębnić czynniki, które sprzyjają większej dzietności. Czynniki te można by było następnie zweryfikować w badaniach statystycznych na większej i bardziej różnorodnej grupie rodzin wielodzietnych, aby sprawdzić, czy są one istotne dla dużych rodzin. Jeśli znaczenie tych czynników znalazłoby potwierdzenie w badaniach statystycznych, można by było sformułować zalecenia dla prowadzenia działań służących zwiększeniu płodności par oraz dokonać przeglądu instrumentów polityki państwa, aby wykluczyć z niej regulacje, które przyczyniają się do zahamowania postaw prokreacyjnych.

\section{Fertility beliefs and attitudes of persons who conscio- usly choose to have a large family}

\section{Abstract}

During the last two decades the fertility rate in Poland was one of the lowest among European countries. There are many studies focusing on reasons for such a phenomenon. However, no research has been done on people who have consciously decided to have a large family. The article provides statistics background on large families in Poland and presents fertility beliefs and attitudes of parents who have three or more children. Qualitative in-depth interviews were conducted with twelve couples who live in large cities. The Theory of Planned Behavior 
(TPB) of Icek Ajzen was applied as an analysis tool. The article is concentrated on one group of factors termed in the TPB as beliefs and attitude toward having a child. The respondents' answers reveal that their beliefs and attitude lead to procreative decisions and strongly coincide with Catholic teachings on marriage and family life: durable and indissoluble marriage, appreciation of the role of the mother and her housework as well as acceptance of every conceived child even if not planned. On the other hand, economic adversity, health problems and difficulties of daily life - classified in the TPB as perceived or actual control - are the main factors responsible for deferring or completing childbearing in large families. If the obtained results are compatible with statistical data the recommendations for family policy could be formulated. 



\section{Tomasz Józefowicz}

Uniwersytet Kardynała Stefana Wyszyńskiego w Warszawie

\section{Polityka rodzinna w Polsce po 1989 roku}

\section{Wprowadzenie}

Jedną z najbardziej trwałych wartości w społeczeństwie polskim jest rodzina. Strategia rozwoju społecznogospodarczego każdego państwa powinna być zgodna $\mathrm{z}$ obowiązującym $\mathrm{w}$ nim systemem społecznych wartości. Polityka rodzinna jest istotnym elementem tworzonego modelu ogólnej polityki społeczno-gospodarczej państwa. Program polityki rodzinnej państwa musi więc mieć charakter długofalowy, systemowy i kompleksowy. Jednym z nadrzędnych długookresowych celów polityki rodzinnej jest tworzenie warunków pełnego rozwoju i funkcjonowania rodziny poprzez wspomaganie jej we wszystkich fazach rozwoju. Realizacja tego celu wymaga zastosowania takich rozwiązań, które docelowo powinny zastąpić dominującą zasadę opiekuńczości państwa zasadą jego pomocniczości wobec rodziny. W tym kontekście podstawową przesłanką wyboru rozwiązań polityki rodzinnej jest powszechny szacunek i akceptacja wartości rodziny oraz przekonanie, że wydatki na rzecz rodziny wychowującej dzieci stanowią inwestycję, która w przyszłości przyniesie społeczeństwu określone korzyści.

Profesor Zbigniew Tyszka ${ }^{1}$ wyróżnia trzy okresy w sytuacji rodzin w Polsce po 1989 r. Pierwszy z nich został nazwany przez niego okresem ",szokowym”, ponieważ przeciętna polska rodzina zmagała się z szokiem wywołanym transformacją ustrojowa, bardzo wysoką inflacja,

$1 \quad$ Por. Wspótczesne rodziny polskie - ich stan i kierunek przemian, red. Z. Tyszka, Wydawnictwo Naukowe UAM, Poznań 2004, s. 19-22. 
restrukturyzacją przemysłu, bezrobociem, wzrostem ubóstwa. Drugi okres wyróżniony przez Tyszkę to lata 19951999 nazwany okresem adaptacyjnym, trzeci okres to czas po 1999 roku. Nieco inną klasyfikację przyjęła Profesor Bożena Balcerzak-Paradowska². Lata 1989-1994 nazwane zostały przez nią pierwszym okresem transformacji. Następnym okresem wyodrębnionym przez nią były lata 1995-2003. Dla potrzeb niniejszego opracowania, okres przyjęty przez Balcerzak-Paradowską wydłużyłem do 2005 roku, tj. do końca rządów SLD-PSL. Następny etap przyjęty przeze mnie to okres od roku 2005, tj. początku rządów koalicji PiS- LPR-Samoobrona, do dnia dzisiejszego. Wyodrębnienie takiego przedziału czasu jest uzasadnione światową sytuacją gospodarczą (kryzys gospodarczy) oraz faktem, że główne siły polityczne w koalicji lat 2005-2007 oraz po 2007 roku, czyli PiS oraz PO, wywodzą się z tego samego nurtu, tak zwanego „postsolidarnościowego" i, pomimo występujących różnic, część działań niewątpliwie odwołuje się do idei Solidarności.

\section{Okres szokowy - pierwszy okres transformacji lata 1989-1994}

Dzień 4 czerwca 1989 r. jest uznawany w Polsce za dzień rozpoczęcia transformacji ustrojowej. Polska, wchodząc w jej okres nie była przygotowana do skutecznego i efektywnego prowadzenia polityki kierującej się wartościami sprawiedliwości społecznej. Wprowadzone reformy systemowe mocno uderzyły w społeczeństwo. W październiku 1989 r. nowo powołany rząd kierowany przez Tadeusza Mazowieckiego zaczął realizować Program Gospodarczy ${ }^{3}$ nazwany od nazwiska głównego realizatora programu Planem Balcerowicza. W planie tym, w rozdziale Polityka społeczna wobec zmiany systemu gospo-

Por. B. Balcerzak-Paradowska, Rodzina i polityka rodzinna na przełomie wieków, IPiSS, Warszawa 2004, s. 218-273.

3 Por Program gospodarczy - Główne założenia i kierunki, Warszawa październik 1989, <www.republika.pl>, (dostęp: 10.10.2012). 
darczego zobowiązano się do wprowadzenia programu osłony grup najsłabszych ekonomicznie. Na uwagę zasługuje jednak fakt, że nie było w programie wzmianki mówiącej o bezpieczeństwie rodziny. Plan Balcerowicza składał się z dziesięciu dokumentów, którym Sejm kontraktowy nadał rangę ustawy. Wśród tak ważnych dokumentów nie było żadnego, który pokazywałby kierunki działań w zakresie polityki społecznej czy rodzinnej. Jedynym aktem prawnym mającym niewątpliwy wpływ na sytuację społeczna, także sytuację rodzin, była ustawa o szczególnych warunkach zwalniania pracowników która zapewniała ochronę zwalnianych z pracy (zwłaszcza w przypadku zwolnień grupowych), gwarantowała dla nich odprawę finansową i wprowadzała okresowe zasiłki dla bezrobotnych.

Priorytetem pierwszego okresu wdrażania reform było ograniczenie hiperinflacji. Najważniejszymi elementami walki z nią były: restrykcyjna polityka dochodowa państwa realizowana poprzez zamrożenie płac i tak zwany popiwek oraz twarda polityka pieniężna Narodowego Banku Polskiego (NBP) realizowana poprzez politykę dodatniej realnej stopy procentowej, celem której było przyciągnięcie gotówki na rachunki bankowe i ograniczenie transakcji gotówkowych oraz dewaluację złotego z wprowadzonym stałym kursem 9500 zł/USD (od maja 1991 r. - 11000 zł). Wprowadzono ponad to ustawowy zakaz zaciagania przez państwo w banku centralnym nieoprocentowanego kredytu na pokrycie deficytu budżetowego. Polityka finansowa państwa ograniczała udział dotacji w wydatkach publicznych z 38\% w roku 1989 do ok. 14\% w roku 1990 i wprowadzała wysoką stopę podatku dochodowego od przedsiębiorstw, instytucji i ludności (50\%). Ponadto nastąpiło otwarcie na handel zagraniczny i zmiana polityki dewizowej poprzez wprowadzenie liberalnego prawa celnego $\mathrm{z}$ jednoczesnym obniżeniem stawek celnych nawet do stawki 0\% (maksymalnie 45\%) oraz brakiem reglamentacji dewizowej. 


\section{Część I}

Współczesna sytuacja demograficzna w Polsce

W zakresie polityki społecznej dla Sejmu zostały przygotowane koncepcje, w których wskazano rodzinę jako jeden $\mathrm{z}$ jej podmiotów ${ }^{4}$. Jednak państwo miało interweniować tylko w sprawach, które nie mogą być załatwione skutecznie przez wspólnoty rodzinne, lokalne, samorządy czy stowarzyszenia. Zakładano aktywny udział społeczeństwa w życiu publicznym z zaznaczeniem, że każdy powinien sam się troszczyć o swoje warunki bytowe. Nie przewidziano jednak sytuacji, że część osób nie będzie umiała się odnaleźć w nowej rzeczywistości. Stabilizacja gospodarki według Leszka Balcerowicza miała polegać na: cięciach budżetowych, zniesieniu dotacji do większości towarów i usług, uwolnieniu cen, płac i stóp procentowych, wprowadzeniu wymienialności złotówki.

Zmiany, które wówczas nastąpiły, były kreowaniem zupełnie nowej jakości życia społecznego i gospodarczego. Zaczęto tworzyć rynkowe warunki funkcjonowania wszystkich jednostek gospodarczych oraz przekształcać infrastrukturę systemową. Nowa sytuacja spowodowała wystąpienie wielu zjawisk negatywnych dla społeczeństwa. Bezrobocie wzrosło w ciągu roku z zera do około 1,1mln. Stopa bezrobocia na koniec 1990 r. wynosiła 6,1\% ${ }^{5}$. W latach 1989-1993 bezrobocie wzrosło do $3 \mathrm{mln}$ osób (15,7\%) i pogłębiło się ubożenie społeczeństwa (40\% ludzi żyło w 1993 r. poniżej minimum socjalnego). Nastąpiło obniżenie realnych płac, rent i emerytur o ok. 30\% oraz o 50\% dochodów rolników (PGR). W efekcie realizacji planu wyhamowano inflację, co przedstawia poniższa tabela.

Por. Koncepcje polityki społecznej w Polsce 1989-1991 - raport BSE, styczeń 1992, nr 12, <www.biurose.sejm.gov.pl>, (dostęp: 11.07.2014).

5 Por. W. Kieżun, Patologia transformacji, Wydawnictwo Poltekst, Warszawa 2012, s. 229. 
Część I

Współczesna sytuacja demograficzna w Polsce

Tabela 1. Inflacja w Polsce w latach 1988-1995

\begin{tabular}{|c|c|c|c|}
\hline Rok & Inflacja & Rok & Inflacja \\
\hline 1988 & $60,2 \%$ & 1992 & $44,3 \%$ \\
\hline 1989 & $639,6 \%$ & 1993 & $37,3 \%$ \\
\hline 1990 & $249,3 \%$ & 1994 & $29,5 \%$ \\
\hline 1991 & $60,4 \%$ & 1995 & $21,6 \%$ \\
\hline
\end{tabular}

Źródło: opracowanie własne na podstawie danych GUS.

Rząd Tadeusza Mazowieckiego nie dotrwał do końca kadencji. Również następujące po nim rządy Jana K. Bieleckiego, Jana Olszewskiego i Hanny Suchockiej, w pierwszej już nie kontraktowej kadencji Sejmu, niewiele uczyniły dla polityki rodzinnej w Polsce. Rządy te skupiły się przede wszystkim na działaniach ratujących naszą gospodarkę, gdyż w latach 1989-1991 nastąpił spadek produkcji o 34\%, w roku 1991 inflacja przekraczała 60\% i wzrastało bezrobocie (1 600 000) oraz deficyt budżetowy. W czasie tej kadencji przygotowano program społeczno-gospodarczy i projekt budżetu państwa na 1992 r. Politycy odeszli w nim od planu Balcerowicza, a skoncentrowali się na powstrzymaniu recesji, ograniczaniu bezrobocia i tworzeniu nowych miejsc pracy oraz dewaluacji złotówki wobec dolara na rzecz wzrostu koniunktury. W pierwszym etapie transformacji, z punktu widzenia rodziny, zauważalny był postępujący wzrost konfliktów wewnątrzrodzinnych. Państwo na skutek innych priorytetów systematycznie zmniejszało pomoc rodzinie. Następowała decentralizacja pomocy w związku z powstaniem samorządów. Zaczął powstawać sektor prywatny w zakresie opieki nad dzieckiem. Pojawiały się pierwsze organizacje non-profit. Jednocześnie ograniczano systematycznie wsparcie rodziny przez pracodawców, wprowadzono nowy system pomocy społecznej, charakteryzujący się niskimi zasiłkami rodzinnymi. Zwolnienia podatkowe dla rodzin zasadniczo nie istniały poza możliwością wspólnego opodatkowania małżonków, co jednak było niewystarczające. Działania 
państwa na rzecz rodziny skierowane były jedynie do rodzin znajdujących się w trudnej sytuacji materialnej, a dominującą formą pomocy były świadczenia pieniężne.

\section{Okres adaptacyjny - lata 1995-2005}

W latach 1995-1997 rządy w Polsce przejęła „lewica”. Na czele rządów stali kolejno: Waldemar Pawlak, Józef Oleksy i Włodzimierz Cimoszewicz. Sojusz Lewicy Demokratycznej (SLD) blokował wszelkie inicjatywy dążące do rozliczenia się z okresem sprzed 1989 r., jednocześnie trudno było dostrzec działania chroniące rodzinę. Polityka rodzinna tego okresu opierała się na ochronie najuboższych, selektywności przyznawania świadczeń i zrównaniu uprawnień kobiet i mężczyzn do świadczeń. Dominującą formą wsparcia pozostawały świadczenia pieniężne. Nie wykorzystywano innych możliwości wsparcia bardziej bezpośredniego. Skupiono się na akcjach dożywiania dzieci w szkołach zarówno przez instytucje państwowe (Ośrodki Pomocy Społecznej), jak i organizacje pozarządowe. Coraz usilniej różne środowiska domagały się podjęcia prac nad rządowym programem polityki rodzinnej, który został przyjęty przez ten rząd w 1997 roku. Program po raz pierwszy w historii transformacji po 1989 roku zakładał wspieranie rodziny jako inwestycję w młode pokolenie. Podjęto też dyskusję nad instrumentami polityki rodzinnej i po analizie sytuacji rodzin zdecydowano się na wybór głównego instrumentu - świadczeń społecznych, które w sytuacji wielu rodzin były jedynym źródłem ich dochodów.

Rozbita opozycja porozumiała się 8 czerwca 1996 r., tworząc wspólną Akcję Wyborczą Solidarność (AWS). Odniosła ona zwycięstwo w przyśpieszonych wyborach we wrześniu 1997 r. (33,8\% głosów), jednak SLD uzyskał niemałe poparcie 27,1\% głosów. Zwycięskie ugrupowanie wraz z Unią Wolności utworzyło rząd, na którego czele stanął profesor Jerzy Buzek. Jednym z głównych zadań umowy koalicyjnej była polityka na rzecz rodzin wyra- 
żona zapisem: Poprawa poziomu życia ludzi oraz poszerzenie praw i zwiększenie samodzielności ekonomicznej rodzin, w tym prowadzenie prorodzinnej polityki finansowej, podatkowej i pomocowej'.

Już wtedy wśród proponowanych rozwiązań na uwage zasługiwały plany, które miały spowodować zmianę postaw prokreacyjnych zmierzających do zwiększenia dzietności rodzin, zahamowania spadku liczby zawieranych małżeństw, wdrożenia skutecznego systemu wspierania budownictwa mieszkaniowego, wprowadzenia, oprócz wspólnego rozliczania małżonków, także innych rozwiązań prorodzinnych w nowelizacji ustaw podatkowych, faktycznego wspierania rodziców w wychowywaniu dzieci i młodzieży, zmiany systemu pomocy społecznej w celu zwiększenia skuteczności jej działań i ukierunkowania jej na zaspokajanie faktycznych potrzeb rodziny.

Program polityki rodzinnej państwa zakładał wdrożenie nowych instrumentów, które miały zapewnić rodzinie samodzielność i bezpieczeństwo materialne oraz przyczynić się do powiększania „kapitału ludzkiego”, co powinno być ważnym perspektywicznie celem, a zarazem wyznacznikiem tempa rozwoju gospodarczego i społecznego. Ważnym wydarzeniem z punktu widzenia rodzin było uchwalenie przez Zgromadzenie Narodowe dnia 2 kwietnia 1997 r. Konstytucji Rzeczypospolitej Polskiej, która w art. 18 stanowi: Małżeństwo jako zwiazek kobiety i mężczyzny, rodzina, macierzyństwo i rodzicielstwo znajduja się pod ochrona i opieka Rzeczypospolitej Polskiej ${ }^{7}$. Tak silne zapewnienie i umieszczone $\mathrm{w}$ najwyższym akcie prawnym Rzeczypospolitej Polskiej (RP) ma swój wymiar symboliczny - państwo deklaruje świadomość wagi rodziny i polityki rodzinnej dla dobra swoich obywateli. Państwo zobowiązuje się w ten sposób do niesienia pomocy rodzinie w każdej sytuacji. Zasada ta została wypowiedziana

\footnotetext{
${ }^{6}$ Umowa koalicyjna AWS-UW, <www.zapis.w.szu.pl>, (dostęp: 14.07.2014).

$7 \quad$ Konstytucja Rzeczypospolitej Polskiej (Dz. U. z 1997r. Nr 78, poz. 483 z późn. zm.), art.18.
} 
w art. 71 Konstytucji. Jego ust. 1. stanowi, że: Państwo w swojej polityce społecznej i gospodarczej uwzględnia dobro rodziny. Rodziny znajdujace sie w trudnej sytuacji materialnej i społecznej, zwłaszcza wielodzietne i niepetne, maja prawo do szczególnej pomocy ze strony władz publicznych ${ }^{8}$.

Z kolei obowiązujący w Polsce Kodeks rodzinny i opiekuńczy $(\mathrm{KRO})^{9}$ opiera się na czterech filarach: trwałości małżeństwa, równouprawnieniu małżonków, ochronie dziecka oraz wzajemnej pomocy członków rodziny. Można sprecyzować również trzy zasady ogólne prawa rodzinnego:

1) zasadę dobra dziecka (zasada nadrzędna),

2) zasadę szczególnej ochrony rodziny,

3) zasadę uniezależnienia osobistych stosunków rodzinnych od wpływów obcych tym stosunkom elementów majątkowych.

W świetle jego postanowień, rodziną jest komórka, której powstanie jest sformalizowane. Powstaje ona bowiem tylko na skutek zawarcia przez kobietę i mężczyznę małżeństwa. Co jest warte podkreślenia, związki faktyczne (konkubinaty) nie stanowią rodziny w rozumieniu KRO. Konkubenci mogą jednak wspólnie wykonywać władzę rodzicielską nad wspólnymi małoletnimi dziećmi. Każdy z rodziców pozostaje jednak w odrębnym stosunku władzy rodzicielskiej i między konkubentami z racji wspólnego wykonywania władzy rodzicielskiej nie powstaje żaden stosunek rodzinnoprawny ${ }^{10}$.

Po roku 1999 nasiliły się rozbieżności między oczekiwaniami większości Polaków, a rzeczywistą kondycją rodzin i obok sukcesów pojawiły się rozczarowania: zły stan służby zdrowia, małe wsparcie państwa, rozwarstwienie ekonomiczne. Przyrost dochodów części rodzin nie nadążał za podwyżkami żywności i energii. Postępował spadek liczby urodzeń oraz liczby małżeństw. Teraz,

Tamże, art. 71.

Kodeks rodzinny i opiekuńczy z dnia 25 lutego 1964 r., tekst jednolity Dz. U. z 2012 r. poz. 788.

10 Tamże, art. 107. 
z perspektywy czasu, można powiedzieć, że był to czas niewykorzystanej szansy. Występujące w latach 1995-1999 ożywienie gospodarki, spadek bezrobocia i inflacji dawały rodzinom nowe możliwości. Podniesienie standardu materialnego części rodzin spowodowało wzrost optymizmu, ale nadal pogłębiało się rozwarstwienie dochodowe. Niestety kontynuowane były niekorzystne trendy demograficzne, a polityka rodzinna cały czas ograniczała się do przekazywania zasiłków rodzinnych.

Sytuacja ta wpłynęła na wynik wyborów, w wyniku których władzę na lata 2001-2005 w Polsce przejął ponownie rząd SLD i Polskiego Stronnictwa Ludowego (PSL). Początek XXI w. to okres, kiedy w strukturze polskich rodzin następowały zmiany podobne do tych, które wcześniej pojawiły się w krajach Europy Zachodniej. Mianowicie zmniejszał się udział małżeństw z dziećmi (z 6323 tys. w 1988 r. do 5860,3 tys. w 2002 r.). Rósł w nich udział rodzin małodzietnych zarówno wśród rodzin miejskich, jak i wiejskich. Rodziny z jednym dzieckiem stanowiły $46,9 \%$ ogółu, z dwojgiem dzieci-36,2\%, a rodziny wielodzietne (mające troje i więcej dzieci) stanowiły - 16,9\%. Następował jednocześnie przyrost rodzin niepełnych ${ }^{11}$. Rząd kierowany przez Leszka Millera doprowadził do likwidacji zasiłku porodowego, ograniczenia kręgu osób uprawnionych do otrzymywania zasiłku rodzinnego, wychowawczego i alimentacyjnego. Do tego trzeba dodać wprowadzenie znacznych oszczędności na zasiłkach z tytułu pomocy społecznej. Działania rządu i polityka koalicji rządzącej były antyrodzinne. Przykładem jest przyjęte wówczas rozszerzenie definicji rodziny. W ustawie z 12 marca 2004 r. o pomocy społecznej (u.o.p.s) rodzinę definiowano jako osoby spokrewnione lub niespokrewnione pozostajace $w$ faktycznym zwiazku ${ }^{12}$. Ustawa ta przyczyniła się też pośrednio do zwiększenia liczby rozbitych rodzin,

11 Por. Ludność. Stan i struktura w przekroju terytorialnym, GUS, Warszawa 2009.

12 Ustawa z dnia 12 marca 2004 r. o pomocy społecznej, tekst jednolity Dz. U. z 2009 r. Nr 175, poz. 1362 z późn. zm., art.6, pkt.14. 
gdyż w celu uzyskania zasiłków część rodzin przeprowadzała rozwód, aby można było skorzystać z przywilejów, jakie wprowadzono w niej dla rodzin niepełnych. Tę sytuację obrazuje poniższa tabela.

\section{Tabela 2. Małżeństwa w Polsce}

\begin{tabular}{|c|c|c|c|}
\hline Rok & $\begin{array}{c}\text { małżeństwa } \\
\text { zawarte }\end{array}$ & $\begin{array}{c}\text { małżeństwa } \\
\text { rozwiązane } \\
\text { przez rozwód }\end{array}$ & $\%$ \\
\hline 1980 & 307373 & 39833 & 13,0 \\
\hline 1990 & 255369 & 42436 & 16,6 \\
\hline 2000 & 211150 & 42770 & 20,3 \\
\hline 2010 & 228337 & 61300 & 26,8 \\
\hline 2011 & 206471 & 64594 & 31,3 \\
\hline 2012 & 203850 & 64432 & 31,6 \\
\hline
\end{tabular}

Źródło: opracowanie własne na podstawie danych GUS.

\section{Okres po roku 2005}

Po kolejnych wyborach w 2005 roku utworzony został rząd koalicyjny Prawo i Sprawiedliwość (PIS) - Samoobrona - Liga Polskich Rodzin (LPR). Jego polityka rodzinna ukierunkowana była głównie na umożliwienie kobiecie godzenia obowiązków rodzinnych $i$ zawodowych; wsparcie finansowe dla rodzin; rozwój społeczeństwa przyjaznego dzieciom $i$ rodzinom ${ }^{13}$. Rząd proponował rozwiązania związane z poprawą kondycji życia polskich rodzin mające na celu zmniejszenie uciążliwości związanych z posiadaniem dzieci oraz podnoszące atrakcyjność rodzicielstwa. Założenia leżące u podstaw tego programu polegały na zastosowaniu kilku rozwiązań charakterystycznych dla koncepcji aktywnej polityki społecznej. Chodziło o przeciwdziałanie dyskryminacji rodzin w zakresie systemu podatkowego i emerytalno-rentowego. Miało to polegać

13 K. Hernik, Rząd ogłosit program polityki rodzinnej na lata 2007-2014, <http://www.isp.org.pl/files/9990299300587150001190796916.pdf>, (dostęp: 11.07.2014). 
m.in. na uzależnieniu wysokości kwoty wolnej od podatku od liczby osób w rodzinie oraz stopniowym zwiększaniu ulgi podatkowej z tytułu wychowywania dzieci. Proponowano również podniesienie do kwoty przeciętnego wynagrodzenia podstawy naliczania składek emerytalnych i rentowych opłacanych przez budżet państwa za osoby pozostające na urlopach wychowawczych. Poza tym zasugerowano potraktowanie kapitału gromadzonego na emeryturę jako majątku wspólnego małżonków. Podjęto również inicjatywę wprowadzenia zachęt dla pracodawców, aby przedłużali zatrudnienie osobom wracającym po przerwie spowodowanej urodzeniem lub wychowywaniem dziecka.

Z powszechną akceptacją partnerów społecznych i pozostałych podmiotów biorących udział w konsultacjach na ten temat spotkały się także aspekty wizerunkowe związane z postrzeganiem dużych rodzin, a mianowicie:

- zmiana wizerunku macierzyństwa, zwłaszcza w kontekście akceptacji dla istniejących i utrwalających się procesów łączenia życia rodzinnego z samorealizacją kobiet w innych dziedzinach życia społecznego;

- tworzenie pozytywnego klimatu dla rodzicielstwa, promocja pracodawców przyjaznych dzieciom, miejsca parkingowe dla osób z małymi dziećmi, przewijaki i miejsca do karmienia w miejscach publicznych, stworzenie karty rodziny wielodzietnej;

- zwiększenie dostępności opieki medycznej dla dzieci i kobiet w ciąży; większa dostępność i elastyczność pracy przedszkoli i żłobków;

- ułatwienie godzenia pracy z macierzyństwem przez uelastycznianie organizacji pracy dla kobiet w ciąży i z małym dzieckiem;

- zrównanie praw pracowników etatowych i osób opłacających dobrowolnie składki chorobowe.

Podmioty biorące udział w konsultacjach społecznych nie mogły jednak dojść do porozumienia w kwestii stopniowego wydłużania urlopów macierzyńskich. Pracodawcy w większości opowiadali się przeciwko wpro- 
wadzeniu takiego rozwiązania, argumentując, że może to spowodować deprecjację umiejętności zawodowych oraz powodować dyskryminację kobiet na rynku pracy. Zwolennicy tego rozwiązania wskazywali na znaczenie stałego kontaktu matki z dzieckiem w pierwszych miesiącach życia dziecka.

Pomimo, iż cały projekt został oceniony pozytywnie, to lista zarzutów do projektu była na tyle długa, że sam projekt był traktowany raczej jako „,dobry start”, a proponowane rozwiązania jako zmierzające w dobrym kierun$\mathrm{ku}$, ale wymagające dopracowania.

W projekcie poza tym brakowało kompleksowych rozwiązań dla rodzin $\mathrm{z}$ dzieckiem niepełnosprawnym oraz rodzin wielodzietnych, szczególnie zagrożonych ubóstwem. Pominięto rodziny wiejskie, które miały ograniczony dostęp do usług zdrowotnych, opiekuńczych i edukacyjnych. Zdiagnozowano co prawda problem źle zorganizowanej i mało efektywnej pracy socjalnej z rodziną w sytuacjach kryzysowych, ale w programie nie znalazły się propozycje, które miałyby charakter prewencyjny i zapobiegałaby kierowaniu dzieci do opieki zastępczej, a właśnie badania nad systemem opieki nad dzieckiem i rodziną w Polsce wskazywały na brak pracy z rodzina, co było jednym z głównych zaniedbań prawodawstwa rodzinnego w Polsce.

W wyniku rozwiązania Sejmu w 2007 roku i przyśpieszonych wyborów władzę w Polsce przejęła koalicja Platformy Obywatelskiej (PO) - PSL. W swoim planie działania przyjęła ona Priorytety $i$ kierunki polityki społecznej w latach 2007-2013 ${ }^{14}$. Zakładały one poprawę warunków powstawania i funkcjonowania rodzin oraz ich wsparcie w wychowaniu i edukacji dzieci. Tym samym zadeklarowano próbę tworzenia i wzmocnienia rozwiązań służących godzeniu pracy zawodowej i wychowywania dzieci.

$14 \quad$ Strategia polityki społecznej na lata 2007-2013, przyjęta przez Radę Ministrów w dniu 13 września 2005 r., <http://www.mpips.gov.pl/gfx/mpips/userfiles/File/nowe/strategiaps.pdf>, (dostęp: 17.07.2014). 
W celu podniesienia aktywności zawodowej oraz umożliwienia pełniejszej realizacji planów prokreacyjnych, podjęto próbę rozwijania nietypowych form zatrudnienia w ramach przepisów prawa pracy umożliwiających łączenie pracy zawodowej i wychowywania dzieci, jednocześnie gwarantujących bezpieczeństwo socjalne rodziny. Wspierano aktywność edukacyjną i zawodowa, upowszechnianie ojcowskiego i macierzyńskiego urlopu wychowawczego, rozwój opieki instytucjonalnej nad dziećmi (w wieku szkolnym), alternatywne formy edukacji przedszkolnej.

W tym miejscu nie da się przeprowadzić jakiejkolwiek analizy ostatnich siedmiu lat rządów Platformy Obywatelskiej (PO) i Polskiego Stronnictwa Ludowego (PSL) bez odniesienia się do przemian następujących w społeczeństwie polskim w zakresie postaw i wartości. W wyniku zachodzących przemian społeczno-gospodarczych doszło do zaadaptowania przez społeczeństwo polskie cech charakterystycznych dla społeczeństw zachodnich, w wyniku czego nastąpiło odrzucenie przez część społeczeństwa dotychczas akceptowanych i pielęgnowanych wartości i postaw. Wchodząc w okres transformacji, Polska nie była przygotowana do skutecznego i efektywnego prowadzenia polityki społecznej kierującej się wartościami sprawiedliwości społecznej, a wprowadzone reformy systemowe uderzyły przede wszystkim w społeczeństwo i rodzinę jako jedną z najważniejszych i najtrwalszych wartości w społeczeństwie polskim. Ponieważ strategia rozwoju społeczno-gospodarczego każdego państwa powinna być zgodna z funkcjonującym systemem społecznych wartości, tak również polityka rodzinna powinna być istotnym elementem tworzonego modelu ogólnej polityki społeczno-gospodarczej państwa. Program polityki rodzinnej powinien więc mieć charakter długofalowy, systemowy i kompleksowy. Jednym z nadrzędnych długookresowych jej celów powinno być stworzenie warunków pełnego rozwoju i funkcjonowania rodziny poprzez wspomaganie jej we wszystkich fazach rozwoju. W tym 


\section{Część I}

Współczesna sytuacja demograficzna w Polsce

kontekście w Polsce podstawową przesłanką wyboru rozwiązań polityki rodzinnej powinien być powszechny szacunek i akceptacja wartości rodziny oraz przekonanie, że wydatki na rzecz rodziny wychowującej dzieci stanowią inwestycję, która w przyszłości przyniesie społeczeństwu określone korzyści.

Dane statystyczne i obserwacja społeczeństwa dają podstawy do stwierdzenia, że w okresie transformacji nastąpiło gwałtowne osłabienie rodziny i jej więzi. Część badań podejmujących zagadnienie wartości najważniejszych dla Polaków jednak temu przeczy.

Badania zrealizowane w 2012 roku przez Centrum Myśli Jana Pawła II we współpracy z CBOS przyniosły interesujące wyniki ${ }^{15}$. W przedziale lat 2007-2012 rodzina nie tylko nie straciła na znaczeniu, lecz stała się dla Polaków jeszcze ważniejsza. Rodzina w 2012 roku podobnie jak w 2007 roku zajmowała pierwsze miejsce na liście spraw bardzo ważnych, zwiększyła się nawet liczba osób, dla których była ona bardzo ważna o 4 procenty. Znajdowała się tuż przed dziećmi, które w stosunku do 2007 roku zyskały 1 procent. Na trzecim miejscu znajdowała się praca, którą wybierano w 2012 roku wyraźnie częściej, bo aż o 9 procent niż 5 lat wcześniej.

Tabela 3. Sprawy ważne w życiu Polaków w latach 2012 i 2007 (w \%)

\begin{tabular}{|c|c|c|c|c|c|}
\hline \multicolumn{5}{|c|}{ Jak ważne są w Pana(i) życiu następujące sprawy? } \\
\hline & \multicolumn{2}{|c|}{2012} & \multicolumn{2}{|c|}{2007} & \multirow{2}{*}{ Ranga } \\
\cline { 2 - 5 } & $\begin{array}{c}\text { Bardzo } \\
\text { ważne }\end{array}$ & $\begin{array}{c}\text { Raczej } \\
\text { ważne }\end{array}$ & $\begin{array}{c}\text { Bardzo } \\
\text { ważne }\end{array}$ & $\begin{array}{c}\text { Raczej } \\
\text { ważne }\end{array}$ & w 2007 \\
\hline 1. Rodzina & 92 & 7 & 88 & 10 & 1 \\
\hline $\begin{array}{c}\text { 2. Dzieci i } \\
\text { potomstwo }\end{array}$ & 75 & 18 & 74 & 15 & 2 \\
\hline 3. Praca & 67 & 27 & 58 & 28 & 3 \\
\hline
\end{tabular}

15 Centrum Myśli Jana Pawła II, Wartości Polaków a dziedzictwo Jana Pawła II 2007-2012, Warszawa 2012. 
Część I

Współczesna sytuacja demograficzna w Polsce

\begin{tabular}{|c|c|c|c|c|c|}
\hline $\begin{array}{c}\text { 4. Przyjaciele } \\
\text { i znajomi }\end{array}$ & 44 & 52 & 47 & 48 & 4 \\
\hline $\begin{array}{c}\text { 5. Wykształ- } \\
\text { cenie }\end{array}$ & 43 & 44 & 41 & 41 & 5 \\
\hline 6. Czas wolny & 41 & 50 & 38 & 52 & 6 \\
\hline $\begin{array}{c}\text { 7. Religia } \\
\text { 8. Dostatnie } \\
\text { życie }\end{array}$ & 37 & 47 & 41 & 40 & 5 \\
\hline $\begin{array}{c}\text { 9. Służenie } \\
\text { innym }\end{array}$ & 29 & 59 & 29 & 49 & 7 \\
\hline $\begin{array}{c}\text { 10. Sukces } \\
\text { kariera }\end{array}$ & 19 & 50 & 18 & 45 & 8 \\
\hline 11. Polityka & 7 & 30 & 7 & 21 & 9 \\
\hline
\end{tabular}

Źródło: Dane Centrum Myśli Jana Pawła II 2007, 2012.

Zdecydowana większość wartości istotnych dla Polaków nie zmieniła swoich pozycji w hierarchii spraw raczej ważnych i bardzo ważnych. W 2012 roku o 3 procent częściej wybierano czas wolny jako bardzo ważny, co sprawiło, że wyprzedził on religię o jedno miejsce na liście. W sumie jednak czas wolny wybrało w 2012 roku (łącznie, ci którzy uważali go za raczej ważny i bardzo ważny) 91\% badanych (wzrost o 1 procent), a religię - 84 procent respondentów, co oznacza wzrost (łącznie dla obu grup) o 3 procenty. Religia w 2012 roku straciła 4 procenty jako sprawa bardzo ważna, ale zyskała 7 procent jako sprawa raczej ważna w życiu respondentów. Tak więc hierarchia wartości Polaków nie uległa w ciągu badanych 5 lat większym zmianom, a rodzinę, pracę, wykształcenie i dzieci wybrało więcej badanych w 2012 roku niż 5 lat wcześniej. Podobnie pozostałe wartości nie zmieniły miejsca w hierarchii. Generalnie wszystkie wartości zyskały, a najwięcej służenie innym, a potem kolejno praca, polityka, sukces i kariera oraz wykształcenie. Respondenci, którzy rzadziej wybierali rodzinę jako sprawę bardzo ważną w swoim życiu, częściej też deklarowali trwanie w związku nieformalnym lub dystansowali się od Jana Pawła II jako autorytetu. Także jednak w zdecydowanej większości 
wybierali rodzinę na pierwszym miejscu bardzo ważnych dla nich spraw. Bardzo ciekawa jest również analiza tabeli 4. W których grupach społeczno-zawodowych rodzina zyskała w tych latach najwięcej? W 2012 roku znacznie częściej za rodziną opowiedzieli się ci, o których przyjęło się sądzić, że będą przewodzić odejściu Polaków od wartości wspólnotowych ku indywidualizmowi i karierze. Tymczasem jest dokładnie odwrotnie. Właśnie rodzina zyskała najwięcej w oczach ludzi młodych, wykształconych i pracujących na własny rachunek.

Tabela 4. Znaczenie rodziny dla różnych grup społeczno-zawodowych w latach 2007 i 2012 (w \%)

\begin{tabular}{|c|c|c|c|c|}
\hline \multirow{2}{*}{} & \multicolumn{4}{|c|}{ Jak ważne są w Pana(i) życiu następujące spra- } \\
\cline { 2 - 5 } & \multicolumn{2}{|c|}{2012} & \multicolumn{2}{c|}{2007} \\
\cline { 2 - 5 } & $\begin{array}{c}\text { bardzo (rodzina) } \\
\text { ważne }\end{array}$ & $\begin{array}{c}\text { raczej } \\
\text { ważne }\end{array}$ & $\begin{array}{c}\text { bardzo } \\
\text { ważne }\end{array}$ & $\begin{array}{c}\text { raczej } \\
\text { ważne }\end{array}$ \\
\hline Ogółem & 92 & 7 & 88 & 10 \\
\hline 15-19 lat & 95 & 5 & 76 & 22 \\
\hline 20-29 lat & 90 & 9 & 83 & 15 \\
\hline 50-59 lat & 90 & 10 & 92 & 7 \\
\hline $\begin{array}{c}\text { Wyższe } \\
\text { wykształ- } \\
\text { cenie }\end{array}$ & 96 & 4 & 88 & 11 \\
\hline $\begin{array}{c}\text { Przedsię- } \\
\text { biorcy }\end{array}$ & 98 & 0 & 88 & 11 \\
\hline $\begin{array}{c}\text { Rolnicy 88 } \\
\text { 12 90 10 }\end{array}$ & 88 & 12 & 90 & 10 \\
\hline
\end{tabular}

Źródło: Dane Centrum Myśli Jana Pawła II 2007, 2012.

W 2012 roku respondenci będący w grupie wiekowej 15-19 lat wybierali rodzinę o 19 procent częściej niż w roku 2007. Także kolejna grupa młodych w wieku 20-29 lat wybierała ją częściej o 7 procent. Dla porównania w grupie wiekowej 50-59 lat rodzina straciła 2 procent. Interesujący jest również fakt, że osoby z wyższym wykształceniem 
oraz pracujący na własny rachunek wybierali rodzinę częściej, tu nastąpił wzrost odpowiednio o 8 i 10 procent.

Nie można odmówić rządowi PO - PSL podejmowania działań, które w konsekwencji zmieniły w sensie pozytywnym sytuację rodzin wielodzietnych. Część z tych działań była wymuszona pogarszającą się gwałtownie sytuacją demograficzna, ponadto organizacje pozarządowe, w szczególności Związek Dużych Rodzin TRZY PLUS, wywierały znaczący wpływ na prowadzone działania władz. W wyniku tych działań pojawiły się urlopy rodzicielskie, karty dużych rodzin dające coraz bardziej znaczące ulgi dla rodzin wielodzietnych, korzystniejsze warunki rozliczeń podatkowych szczególnie dla rodzin z trojgiem lub większą liczbą dzieci. Były też działania, które utrudniały życie rodzinom. Mam tutaj na myśli zwiększenie obciążenia podatkiem VAT na artykuły dziecięce. Trzeba jednak przyznać, że rozwiązań pozytywnych z punktu widzenia rodziny wielodzietnej było zdecydowanie więcej. Nie można jednak przejść obojętnie obok postawy władz wobec rodzin mających trudności opiekuńczo-wychowawcze. Rodziny oczekiwały wsparcia dla rodziny biologicznej oraz pomocy rodzinom w przezwyciężaniu trudności materialnych, emocjonalnych i wychowawczych. Oczekiwano wsparcia w zapewnieniu warunków do prawidłowego realizowania funkcji ekonomicznej, wychowawczej, opiekuńczej i emocjonalnej. Przyjęto w tym kontekście regulacje prawne, które zamiast wsparcia ułatwiały zabieranie rodzicom dzieci nie tylko z powodów występujących patologii, ale również na przykład z powodu biedy czy bezrobocia ${ }^{16}$.

\section{Podsumowanie}

Głównymi instrumentami polityki rodzinnej w Polsce po 1989 roku były świadczenia pieniężne, czyli zasiłki

\footnotetext{
16 Ustawa z dnia 9 czerwca 2011 r. o wspieraniu rodziny $i$ systemie pieczy zastępczej (Dz.U. 2011 nr 149 poz. 887 z późn.zm.)
} 
rodzinne, dodatki z tytułu niepełnosprawności dziecka, opieki nad dzieckiem w okresie urlopu wychowawczego, samotnego wychowywania dziecka, rozpoczęcia roku szkolnego, podjęcia nauki przez dziecko poza miejscem zamieszkania oraz tak zwane becikowe. W III Rzeczypospolitej wykorzystano również wcześniej stosowane instrumenty umożliwiające godzenie obowiązków zawodowych i rodzinnych - urlop i zasiłek macierzyński, urlop i zasiłek wychowawczy, zasiłek opiekuńczy. Dodatkowym narzędziem wspomagającym rodzinę były ulgi podatkowe, a przede wszystkim wspólne opodatkowanie małżonków oraz osób samotnie wychowujących dzieci oraz zwolnienie od podatku świadczeń rodzinnych. Długofalowa polityka rodzinna w Polsce po 1989 r. była przykrywana doraźnymi problemami i potrzebami. Brakowało głębszego przekonania o wadze działań prorodzinnych i uznania ich za jeden z priorytetów polityki kolejnych rządów. Trudności przynosi również wyróżnienie długoterminowej koncepcji realizowanej ponad politycznymi podziałami w okresie ostatnich ponad dwudziestu lat dla wsparcia polityki rodzinnej. Tematyka ta była wdzięcznym obszarem politycznych obietnic, nieliczne były jednak wymierne działania. W tym czasie przygotowano kilka dokumentów strategicznych dotyczących polityki rodzinnej. Były to między innymi:

1. Program Polityki Rodzinnej z 1997 r.;

2. Polityka Prorodzinna Państwa z 1999 r.;

3. Strategia polityki społecznej na lata 2002-2005;

4. Narodowa Strategia Integracji Społecznej z 2003 r.;

5. Narodowy Plan Działań Wobec Dzieci 2004-2012 „Polska dla Dzieci";

6. Strategia Państwa dla Młodzieży na lata 2003-2012;

7. Strategia Polityki Społecznej na lata 2007-2013;

8. „Polska 2030. Wyzwania rozwojowe” - dokument z 2009 r. (część II dotycząca wyzwań demograficznych). 
Ponieważ strategie uchwalane przez kolejne rządy trafnie diagnozowały problemy polskiej rodziny, nic nie stało na przeszkodzie, aby politykę rodzinną bardziej efektywnie realizować. Niestety siłom politycznym zabrakło wyobraźni i woli politycznej. W licznych opracowaniach, raportach i relacjach z badań prowadzonych w okresie transformacji wskazuje się, że konieczne jest jasne zdefiniowanie miejsca rodziny w całokształcie polityki społecznej państwa oraz zapewnienie niezbędnych środków umożliwiających zaspokojenie podstawowych i rozwojowych potrzeb rodziny. W Polsce problemy rodziny znajdowały się w gestii wielu resortów m.in. Ministerstwa Pracy i Polityki Socjalnej, Ministerstwa Zdrowia, Ministerstwa Edukacji Narodowej. W kwietniu 1991 roku uchwałą Nr 53/91 Rady Ministrów po raz pierwszy powołany został Pełnomocnik Rządu ds. Kobiet i Rodziny, którego zadaniem było koordynowanie polityki państwa wobec rodziny. Urząd był ciągle reorganizowany, następowały ciągłe zmiany pełnomocników i zakres zadań, a nazwy ewoluowały. Było to moim zdaniem jedną z przyczyn tego, że przez ostatnie 25 lat władze polskie nie wypracowały jednolitego, wewnętrznie spójnego programu polityki rodzinnej, który poza działaniami wspierającymi rodzinę miał umożliwić odrodzenie demograficzne społeczeństwa. W ostatnim czasie pojawił się kolejny aspekt, jakim jest próba redefinicji pojęcia rodziny, którą próbują przeprowadzić środowiska związane z ugrupowaniami lewicowymi. W związku z tym ośmielę się stwierdzić, że rodzina jest grupą czy instytucją społeczną szczególnie podatną na wpływy instytucji społeczno-politycznych, mediów, ekonomii i gospodarki. Jednocześnie rodzinie potrzebne jest jednoznaczne wsparcie ze strony autorytetów i władz państwowych. 


\section{Część I}

Współczesna sytuacja demograficzna w Polsce

\section{Rysunek 1. Co wpływa na rodzinę w Polsce po 1989 roku.}

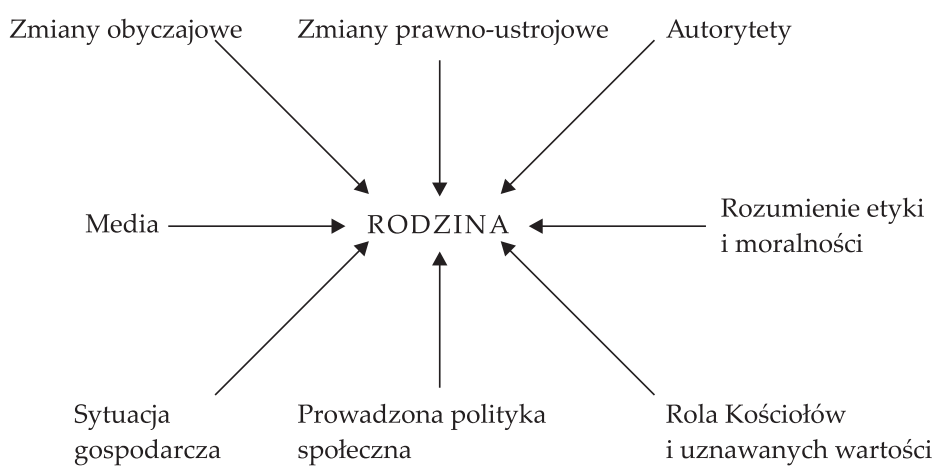

Źródło: opracowanie własne

\section{Family policy in Poland after 1989}

\section{Summary}

The article has on purpose to introduce changing family politics in Poland after 1989, situation of families, especially large families. Family problems have been subjected to confrontation with mechanisms and instruments of family policy, which should help in its implementation. Autor presents actions of successive governments which were implemented during a political transformation.

Basic terms:

- law resolutions

- family policy - terms, ways of realisation

- family policy during political transformation

- polish family policy

- placement family policy in social policy

- tips and instruments of family policy

The article is based especially on council and government documents. Autor uses also for analysis his own experience. 


\section{Rafał Maciąg}

Uniwersytet Warszawski

\section{Aborcja z perspektywy personelu medycznego}

\section{Problematyka i przedmiot badania}

W niniejszym artykule przedstawiam wyniki badania zjawiska aborcji, które przeprowadziłem z personelem medycznym. W czasie wzmożonej dyskusji nad dopuszczalnością przerywania ciąży media informuja, że lekarze odmawiają zabiegów z powodu klauzuli sumienia i istnieje rozległe podziemie aborcyjne. Celem mojego badania było zrozumienie sytuacji społecznych na poziomie pracy personelu. Chciałbym odpowiedzieć na pytanie, co powoduje nieliczne zarejestrowanie przerwań ciąży w szpitalach (752 przypadki w 2012 r. ${ }^{1}$ ), gdy organizacje kobiece podają szacunki podziemia aborcyjnego w przedziale 80-200 tys. zabiegów² ${ }^{2}$ Niezależnie od tego, badanie demograficzne dla dwóch roczników w latach 90. XX w. wykazało przedział 100-120 tys. aborcji ${ }^{3}$. Istnieją też obliczenia organizacji pro-life, wskazujące na znacznie niższe wartości - 7-14 tys. ${ }^{4}$. W Polsce notuje się niski przyrost naturalny, który nie zapewnia zastępowalności pokoleń. W okresie obowiązywania Ustawy o warunkach dopuszczal-

1 Por. Sprawozdanie Rady Ministrów z wykonania w roku 2012 Ustawy z dnia 7 stycznia 1993 r. o planowaniu rodziny, ochronie płodu ludzkiego i warunkach dopuszczalności przerywania ciąży (Dz.U.1993, Nr 17, poz.78 z późn. zm.), <http://orka.sejm.gov.pl/Druki7ka.nsf>, (dostęp: 21.02.2015).

2 Por. W. Nowicka, Ustawa antyaborcyjna w Polsce, dz. cyt., s. 27.

3 Por. I. Jaruga, Bezpośrednie determinanty płodności. Aplikacja modelu Bongaartsa dla Polski dla lat 1991 i 1995, „Studia Demograficzne” (1999), nr 2, s. 95-120.

4 Por. M. Stachura, B. Trzcińska, J. Wronicz, Podziemie aborcyjne w Polsce, Artykuł powielany z 2003 r. Dostępne na stronie Tygodnika „Niedziela": <http://www.niedziela.pl/artykul/73520/nd/Podziemie-aborcyjne\#>, (dostęp: 21.02.2015). 
ności przerywania cią̇̇y z 1956 r., w pierwszej połowie lat 80. XX w. liczba urodzeń była o połowę wyższa niż obecnie, przekraczając 700 tys., ale rejestrowano 135 tys. aborcji, natomiast podziemie szacowano na 620 tys. ${ }^{5}$, a nawet 800 tys. $^{6}$. Bardzo trudno jest dzisiaj ustalić wielkość szarej strefy. W poniższym badaniu jakościowym nie zajmuję się określeniem tego problemu, ale przyjmuję założenie, że w dyskusji na ten temat dane urzędowe oraz nielegalne podziemie są elementami społecznego konstruowania wiedzy, kształtującego działania jednostek i instytucji ${ }^{7}$. W świecie zachodnim liczby są argumentami racjonalnymi, wspierającymi debaty publiczne. Na wiele decyzji politycznych (referenda, konsultacje, głosowania) wpływ ma ekonomiczna policzalność, stanowiąc niejednokrotnie mocniejszy argument od koncepcji moralnych.

Wydaje się faktem bezspornym, że szpitale zaniżają dane aborcyjne w wyniku nacisku politycznego i obyczajowego. W tym kontekście, statystyka stanowi okazję do pokazania własnej działalności jako odpowiedniego zarządzania organizacją w ramach ustalonych norm społecznych i wymogów w obszarze narodzin i śmierci. Szpitale starają się realizować politykę zdrowotną w dziedzinie opieki nad matką i dzieckiem, zwłaszcza od czasu uchwalenia Ustawy o planowaniu rodziny, ochronie płodu ludzkiego i warunkach dopuszczalności przerywania ciąży z dnia 7 stycznia z $1993 \mathrm{r}$.

W prezentowanym badaniu brali udział ginekolodzy, pielęgniarki i położne, ponieważ mają oni dużą wiedzę z praktyki lekarskiej. Badania aborcji z perspektywy kobiet byłyby bardzo interesujące, jednakże w tym wypadku idzie o to, jak ów problem widzi personel mający niejednokrotnie bezpośredni wpływ na ich losy oraz na tworze-

Por. M. Okólski, Zapobieganie i przerywanie ciązy w Polsce, „Studia Demograficzne" (1984), nr 2, s. 45-75.

6 Por. K. W. Meissner, Częstość poronień, „Słowo Powszechne” (1991), nr 85-86 (XLV), z dnia12-13-14.04.1991.

7 Por. P. L. Berger, T. Luckmann, Społeczne tworzenie rzeczywistości, Państwowy Instytut Wydawniczy, Warszawa 1983, s. 106. 
nie wiedzy medycznej, w tym dokumentacji. W drodze wywiadów pogłębionych chciałem dowiedzieć się, w jaki sposób szpitale rejestrują zabiegi oraz co wpływa na niechęć do wydawania skierowań na badania genetyczne i aborcję. W badaniu zajmuję się więc prawem lekarza do klauzuli sumienia, a także analizą tego, co ginekolodzy sądzą o pacjentkach decydujących się na przerwanie cią$\dot{z} y^{8}$. W gabinetach prywatnych interesowały mnie historie kobiet zgłaszających lekarzom swe wątpliwości co do urodzenia dziecka.

\section{Metoda badania}

Choć badanie zostało przeprowadzone już jakiś czas temu (lipiec 2003 r. - kwiecień 2004 r.), zdecydowałem się teraz opublikować wyniki, ponieważ podejmowany problem jest wciąż aktualny, a warunki prawne i dane oficjalne nie zmieniają się $e^{9}$ Tam, gdzie było to możliwe, podaję nowe informacje na podstawie pojedynczych rozmów z członkami personelu oddziałów położniczych (2014 r.). Badanie podstawowe obejmowało 18 wywiadów pogłębionych, z czego 17 odbyło się w Warszawie i 1 w Lubartowie w województwie lubelskim. W Warszawie zatrudnia się wielu lekarzy, a aglomeracja zapewnia anonimowość i sprzyja badanemu zjawisku. W szpitalach warszawskich rejestruje się $90 \%$ przerwań ciąży. Dla kontrastu jeden wywiad odbył się w Lubartowie, mieście liczącym 26 tys. mieszkańców. W województwie lubelskim przez kilkanaście lat nie zarejestrowano ani jednej aborcji, a w samym Lubartowie już od 1980 r. ordynator oddziału nie wyrażał na nie zgody.

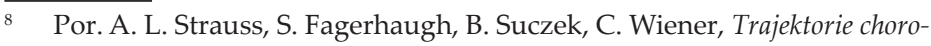
by, w: Metoda biograficzna w socjologii. Antologia tekstów, red. K. Kaźmierska, Nomos, Kraków 2012, s. 373-388.

9 Badanie zostało zrealizowane $\mathrm{w}$ ramach mojej rozprawy doktorskiej pt. Społeczna konstrukcja i społeczne wykorzystanie danych medycznych. Przypadek aborcji, Instytut Socjologii Uniwersytetu Warszawskiego, Warszawa 2007, pod kier. naukowym prof. Antoniego Sułka.
} 
Osoby do badania zostały dobrane celowo ze względu na zatrudnienie $w$ klinikach, gabinetach prywatnych lub pełnienie wysokich funkcji w hierarchii instytucjonalnej. Jeżeli chodzi o lekarzy, dziewięć wywiadów przeprowadziłem z ginekologami: czterech z nich było ordynatorami oddziałów lub kierownikami klinik, z tego dwaj pełnili funkcję konsultanta krajowego w dziedzinie ginekologii i położnictwa (jeden $\mathrm{z}$ nich pełnił tę funkcję w czasie badania, a drugi to były konsultant). Jednocześnie są to profesorowie i kierownicy klinik (L3, L10). Dwaj następni to profesorowie będący kierownikami innych klinik uniwersytetu medycznego (L1, L8). Jeszcze inny lekarz był asystentem (L4) kierownika kliniki, w której dokonywano aborcji. Pięć wywiadów przeprowadziłem z ginekologami w ich gabinetach prywatnych (L1, L2, L5, L6, L7). W tym celu dzwoniłem pod numery ogłoszeń prasowych o treści „zabiegi tanio". Wielu lekarzy nie wyrażało zgody na udział w badaniu, ale kilku udało się przekonać do anonimowej rozmowy. Jak się potem okazało, wszyscy oni pracowali też na oddziałach szpitalnych. Kwestia dość ważnej społecznie aborcji w wyniku upośledzenia płodu i nieuleczalnych chorób zagrażających jego życiu (wad płodu) została omówiona w wywiadzie z lekarzem genetykiem (L9). Pozostałe osiem wywiadów przeprowadziłem z pielęgniarkami i położnymi: trzy z nich zatrudnione były na oddziałach położniczych (P1, P2, P3), cztery - w dwóch poradniach na Grochowie (P4, P5) i na Woli (P6, P7), a ostatnia była pielęgniarką środowiskową (P8) opiekującą się klientkami pomocy społecznej, rodzinami wielodzietnymi i samotnymi matkami na Mokotowie.

\section{Aborcja w gabinecie}

Celem jednego z pierwszych pytań było ustalenie, jak często kobiety mówią lekarzom o niechcianej ciąży. Pytałem, ile kobiet zgłasza ten problem przeciętnie na miesiąc. Tylko kilku z nich było w stanie określić liczbę takich pacjentek. Oto odpowiedzi w kolejności od najczęstszych do 
najrzadszych zgłoszeń tego typu: 2 pacjentki na tydzień lub 1 na miesiąc (L2), 1-2 pacjentki na rok lub kilka na miesiąc (L7), 5-6 pacjentek na rok (L5), 3 pacjentki na rok (L3). Na wiarygodność odpowiedzi mógł wpływać prawny zakaz aborcji, a także sytuacja nagrywanego wywiadu. Ginekolodzy z pewnością mówili tylko tyle, ile chcieli. Zapewniono mnie, że do większości z nich pacjentki nie przychodzą w celu pozbycia się ciąży, z góry wiedząc, kto zajmuje się aborcją i informując się wzajemnie. Motywów aborcji jest wiele, a są to: lęk przed utratą pracy, niechęć do przerywania kariery zawodowej, u małżeństw jest to niechęć do posiadania kolejnego dziecka, najczęściej trzeciego lub niechęć do wychowywania dziecka z upośledzeniem umysłowym, u młodych kobiet niezamężnych jest to niechęć partnerów wobec dziecka i straszenie odejściem, u młodych kobiet jest to często nieplanowana ciąża w czasie studiów i przed ślubem, u mężatek - niedochowanie wierności. Kobiety będące w stałym związku z mężczyzną i z jednym dzieckiem częściej akceptują kolejną ciążę niż osoby samotne i niezamężne. Zdarzają się nieliczne sytuacje, gdy mężowie/partnerzy skutecznie przekonują swoje partnerki do urodzenia dziecka, ale o wiele rzadziej występują przypadki podobnego wywierania wpływu, gdy para nie planuje wspólnego życia. Rodzice potrafią podjąć arbitralną decyzję o usunięciu ciąży wbrew nieletniej córce, gdy stać ich na zabieg zagranicą (L4). Powodem aborcji u młodych dziewcząt jest też oczywiście ukrywanie ciąży przed rodzicami. Tak więc, decyzje o aborcji są często podejmowane przez osoby znaczące dla kobiety: rodziców, męża, partnera lub teściów, a czasem jest to tzw. niepożądana ciąża ze względu na sytuację życiową lub zawodową. Zdaniem kilku ginekologów, taka decyzja wynika nader często z obaw o utratę pracy (L1, L5, L6). Tych powodów nie uwzględnia żadna statystyka, co więcej, lekarz nie wpisuje ich do kartoteki, bo nie stanowią one istotnych problemów medycznych.

Kobiety z wątpliwościami co do urodzenia dziecka umawiają się na wizytę do ginekologa. Zdaniem lekarzy, 
ginekolog jest osobą zaufana, a wywiad lekarski może być dla pacjentki nawet ważniejszy niż rozmowa z osobą bliska, ponieważ argumenty lekarza sa bardziej przekonujace niż partnera, który niejednokrotnie waha się, czy w trudnej sytuacji nie opuścić kobiety (L3). Wywiad ma też na celu przedstawienie mocnych i słabych stron aborcji, przy czym ostateczny wybór pozostawia się kobiecie (L3). W wyniku takiej wizyty zdarza się, że kobiety porzucają wątpliwości i rodzą. Ważne są tu różne czynniki, jak upływający czas, argumenty zdrowotne i nie mniej istotne wsparcie rodziny (L4, L7). W wypadku niepowodzenia rozmowy i braku zmiany decyzji, lekarz zwykle prosi o ponowną wizytę za dwa tygodnie. Jednak niektóre kobiety już nie przychodzą (L3, L8). Jak wspomniano, czynnikiem decydującym o pozytywnym nastawieniu do ciąży jest oparcie w stabilnej sytuacji rodzinnej (L10). Jednak nie jest to reguła, gdy chodzi o urodzenie trzeciego i następnego dziecka, dziecka upośledzonego lub tym bardziej o ciążę pozamałżeńską. Według kilku osób badanych, kobieta zdecydowana na aborcję nie idzie do swojego lekarza po poradę, tylko od razu szuka gabinetu, w którym usunie ciążę (L4, L5, L6).

Poszukiwałem informacji na temat cen aborcji i kryteriów opłat. Poradnia lub szpital mogą wykonywać bezpłatnie usługi dopuszczalne przez prawo i za skierowaniem specjalisty, a za nielegalne przerwanie ciąży lekarzowi grozi kara pozbawienia wolności do lat trzech. Nielegalność oznacza ryzyko i dlatego jest to ważne kryterium opłaty. W dodatku zabieg może się nie udać, zwłaszcza, gdy wykonywany jest w warunkach ograniczonego bezpieczeństwa ${ }^{10}$. Lekarze na ogół deklaruja, że nie znają takich cen i tylko jeden $z$ nich powiedział, że na rynku zabieg kosztuje dwa, trzy, cztery tysiące złotych (L4). Według położnych ceny wahają się między 1 tys. a 5 tys. zł (P1, P4, P6, P7, P8).

10 Por. M. Nesterowicz, Prawo medyczne, Wyd. VII, TNOiK - Dom Organizatora, Toruń 2005, s. 191-209. 
Osoby badane wymieniały też kryteria opłat, które ogólnie dzielą na medyczne (czas trwania ciąży, metoda zabiegu) i pozamedyczne (liczba członków personelu przy zabiegu). Najważniejszym kryterium opłaty jest stopień zaawansowania ciąży, czyli określenie jej terminu $\mathrm{w}$ tygodniach. Po dopuszczalnym terminie 12 tygodni niewielu lekarzy decyduje się na zabieg, a koszt uzależnia właśnie od wieku nienarodzonego dziecka. Jedna z lekarek tłumaczy to w interesujący sposób, przekornie odnosząc się do zasady animacji, to jest do momentu wstąpienia duszy do ciała, doktryny, która utraciła swą ważność na rzecz wiedzy przyjętej w wyniku odkryć medycyny w dziedzinie zapłodnienia. Sa lekarze, którzy 'uważaja', że dusza wstęuje po dwunastym tygodniu, czyli do dwunastego [tygodnia] można przerywać ciąże, a potem, po dwunastym tygodniu, jak wstepuje dusza, to nie. W zwiazku z czym, do dwunastego tygodnia przerywaja te ciaże. Zbyt wczesne wywołanie porodu, nie w terminie, owocuje różnymi patologiami, które się moga zdarzyć. Stąd może ta cena być wyższa w związku z wyższym ryzykiem. Dlaczego wyższa? Dlatego, że ryzyko jest ogromne (lekarka 8, 49 lat). Wyjątkiem jest tu aborcja w wyniku upośledzenia płodu lub ciężkiej i nieuleczalnej choroby zagrażającej jego życiu, w Polsce dopuszczalna do 24 tygodnia ciąży. Przepisy Światowej Organizacji Zdrowia określaja, że aborcji można dokonać do 22 tygodnia, a jedna z położnych mówi, że w jej klinice dokonuje się aborcji nawet ok. 30 tygodnia ciąży ${ }^{11}$. Wpływ na koszty ma też liczba osób uczestniczących w zabiegu. Niektórzy ginekolodzy zatrudniają prywatnie anestezjologów do trudnych zabiegów, ale większość nie zatrudnia nikogo z powodu oszczędności, choć wymogi formalne mówią o asyście całego zespołu. Na pewno cena zależy od leków, od gabinetu, od stopnia specjalizacji, czy tam jest doktor nauk medycznych, tak samo jak we wszystkich innych gabinetach, a oprócz tego, że to jest niezgodne z prawem (położna 3, 48 lat).

11 Rozmowa w 2014 r. 


\section{Część I}

Współczesna sytuacja demograficzna w Polsce

Pewna pielęgniarka z przychodni publicznej (P4) opowiedziała o propozycji współpracy z ginekologiem, swoim szefem, polegającej na kierowaniu pacjentek zdecydowanych na aborcję do jego gabinetu prywatnego. Umowa opiewała na dziesięć procent z jednego tysiąca złotych, które lekarz życzył sobie na wstępie. Pielęgniarka zastrzegła, że na razie jest to bezowocna niepisana umowa. Z lekarzem nie udało się przeprowadzić wywiadu. Usługi nieformalne są zjawiskiem bardzo zróżnicowanym i to do tego stopnia, że istnieją wyjątki polegające na rezygnacji z opłat lub znacznym ich obniżaniu (rodzina, znajomi; L4). Pielęgniarki i położne przebywają na oddziale praktycznie przez cały dzień i dzięki temu znają problemy kobiet. Zaufanie pacjentki do pielegniarki lub położnej wynika z podobieństwa problemów tej samej płci i jednocześnie z mniej sformalizowanej roli niż jest to w przypadku kontaktu z lekarzem. Oczywiście, nie wszystkie tego typu relacje wyglądają tak samo i jednakowo odnoszą się do każdego przypadku ${ }^{12}$. Jednak niektóre kobiety same opowiadają pielęgniarkom swoje historie, na przykład właśnie o tym, ile zapłaciły za zabieg (P6). Mimo dokumentowania spraw, historie ciąży urywają się i widać braki w ciagłości. Piszę, że po prostu poroniła. Czy ma pani dokumenty? 'Nie mam. Nie wzięam. Zapomniałam'. Bo wiadomo, że jakby rzeczywiście poroniła, jakby do szpitala przyszła, poronienie w toku, to wiadomo, że ma wypis ze szpitala. Wedle relacji pacjentki: 'Ciaża została poroniona', no, bo tu też trzeba przyjać to, że ona mówi prawdę. Nie możemy negować, że nie, albo w ogóle się nie pojawia, np. przez rok. Co się stało, nikt nie pyta, no, bo to było lata całe temu. Zostaje zapomniane (położna 6, 50 lat).

Trzynastoletnie i nieco starsze dziewczęta zachodzą w ciąże i nie wiadomo, co dzieje się z nimi, jeżeli potem nie przychodza na kolejne wizyty kontrolne (P7). W kartotece

12 Por. A. Ostrowska, Paternalizm czy partnerstwo? Relacje między pacjentami a lekarzami w Europie, w: W środku Europy? Wyniki Europejskiego Sondażu Społecznego, red. H. Domański, A. Ostrowska, P. B. Sztabiński, Wydawnictwo Instytutu Filozofii i Socjologii PAN, Warszawa 2006, s. 185-201. 
notuje się ciążę z niejasnym przebiegiem, a po kilku tygodniach ta sama osoba prosi już o środki antykoncepcyjne (P6, P7). Ginekolog z Lubartowa powiedział, że z aborcji płatnej korzystają kobiety w wieku od 32 do 40 lat, które mają już dzieci (L5).

\section{Postrzeganie pacjentek przez personel}

Lekarze postrzegają swoje pacjentki poprzez określone kategorie i ramy społeczne. Przywołują oni przykłady z praktyki, które stały się na tyle charakterystyczne, że zapamiętali je na długo, i co ciekawe, są to opowieści kojarzące się z niecodziennymi wydarzeniami. Mimo że nie prowadzi się żadnych badań ani statystyk w tym zakresie, to owa wiedza „potoczna” wydaje się być trwale ukształtowana pod wpływem określonych kategorii i stereotypów zawodowych. Na przykład, dla lekarzy status materialny pacjentek jest dość ważny, ale nie tyle idzie tu o możliwości ewentualnych opłat, co o postrzeganie pacjentek poprzez pewne ustalone społecznie kategoryzacje. Tak więc kobieta o wyższym statusie materialnym ma łatwiejszy dostęp nie tylko do aborcji, ale przede wszystkim do usług prywatnych niż ta o niższym dochodzie (L2).

Najczęściej sa to kobiety wyksztatcone, wcale nie te proste. Najczęściej sa to kobiety z jakimś zawodem i z ustawionym domem $i$ im $w$ danym momencie to [dziecko] nie pasuje. $W$ danym momencie to im przeszkadza w życiu. A to teściowa z nimi mieszka, a to jeszcze domu nie wybudowali, a to pierwsze dziecko nie stało się na tyle dojrzałe, żeby można się decydować na drugie. Najczęściej sa to kobiety wykształcone, ze świadomym wyborem (lekarka 8, 49 lat).

Do drugiej grupy należą pacjentki ze szpitala, niejednokrotnie mające po kilkoro dzieci, które - zdaniem lekarzy - w ogóle nie zajmują się planowaniem rodziny lub stosują nieskuteczne naturalne metody regulacji urodzeń (L2; też L4, L6, L7). Wynika stąd, że kobieta im „lepiej wykształcona”, a tym samym „lepiej uświadomiona” w kwestii zapobiegania ciąży, tym później decyduje się na dzieci 
i mniej ich rodzi. W potocznym rozumieniu „wykształcenie" pacjentki będzie oznaczać odpowiedni poziom komunikowania w czasie wizyty, zrozumiały i dostosowany do sposobu pojmowania lekarza. W praktyce coś takiego jest iluzja, bo pacjentki pochodzą z różnych warstw społecznych. Ale chodzi tu o wymianę informacji zwrotnych, dzięki którym lekarz orientuje się, czy pacjentka przyswoiła różne zalecenia w sprawie leków i badań lekarskich.

„Pacjentka wielodzietna” często kojarzona jest z brakiem wykształcenia, bezrobociem i ubóstwem (L4, P8). Panuje niemal powszechne przekonanie, że kobiety „o niższym statusie", mające już dzieci, będą rodzić kolejne. „Taka wielodzietna” nie przyjdzie do gabinetu prywatnego, a lekarz spotyka ją na oddziale położniczym w czasie kolejnego porodu (L4). Aż sześć osób widzi te kobiety jako osoby, które po porodzie pozostawiają dzieci w oknach życia (L2, L8, P2, P6, P7, P8). Takie zachowanie lekarze oceniają $\mathrm{z}$ reguły nagannie, ponieważ matka powinna wychowywać swoje dziecko. Prawie wszystkie te osoby były zgodne co do tego, że lepszym rozwiązaniem od okna życia jest aborcja.

Ta pacjentka, która ma wyższy status i to, co zwykle wiq$\dot{z}$ e się z większa inteligencja, wyższym wykształceniem, to ona przyjdzie i te ciąże usunie. Natomiast te wszystkie pacjentki jak gdyby z nizin, to przyjda, urodza dziecko i zostawia w szpitalu (lekarka 2, 34 lata).

Kobiety rodzące z reguły nie uzyskują dostatecznej informacji na temat dostępu do badań, leczenia czy opieki nad dzieckiem upośledzonym ${ }^{13}$. Tylko trzech lekarzy i położne starają się udzielać szerszej informacji na ten temat, a inni twierdza, że na dłuższą rozmowę o tych sprawach nie mają czasu.

Jednocześnie ginekolodzy uważaja, że brak wiarygodnych danych na temat przerwań ciąży z gabinetów prywatnych przyczynia się do wielu negatywnych zjawisk,

13 Por. E. Zakrzewska-Manterys, Down i zespót watpliwości. Studium z socjologii cierpienia, Wydawnictwo Naukowe "Semper", Warszawa 1995, s. 35-36. 
takich jak brak planowania usług zdrowotnych, brak pomocy pielęgniarskiej i anestezjologicznej, złe warunki sanitarne zabiegów.

Cała ogromna masa przerwań ciązy ze wskazań nazwijmy to społecznych lub niespołecznych, bo to czasem jest kwestia tak zwanego przerwania ciaży na życzenie, to ta ogromna masa trafia do prywatnych gabinetów, czyli jest to strefa szara. I w zwiazku z tym, tu nie ma żadnej ewidencji, to jest bardzo niedobre, że nie ma żadnej ewidencji, bo można tylko jakieś szacunkowe wartości przyjmować (lekarz genetyk 9, 67 lat).

\section{Poronienia szpitalne}

Mówiąc o tzw. szarej strefie, wypada zwrócić uwagę na czynniki sprzyjające jej istnieniu. Jednym z nich jest aborcja farmakologiczna, dzisiaj bardzo rozpowszechniona. Tabletki aborcyjne są dostępne u lekarzy w gabinetach, w aptece i w Internecie, już od 50 zł. Tabletka aborcyjna RU-486, którą stosuje się do 8 tygodnia ciąży, dopuszczalna jest w kilku krajach zachodnich, ale w Polsce nie zarejestrowano jej z powodu istniejących przepisów ${ }^{14}$; jednak położne są zdania, iż dostępne są w niektórych gabinetach. Poza tym w Internecie można kupić tanie leki na bóle żołądka działające poronnie.

Jeżeli coś jest zrobione z ciąża w mieście, to najczęściej za pomoca środków farmakologicznych, tabletkami, wtedy nikt nie będzie wiedziat, dlaczego ciąża jest obumarła. Więc wszystkie panie przychodza [do szpitala na operacje], po prostu aborcja. Nie sadze, że w tej chwili jakakolwiek statystyka jest możliwa. Jeśli chodzi o małe ciąże, pójdzie do gabinetu i znajdzie kogoś. Do zabiegu przyjdzie tutaj. A tam dostanie tabletke poronna. Kobiety nie mówia, dlaczego poronity. Nie ma możliwości, by sprawdzić, by się dowiedzieć. Kobieta przyjeżdża i roni, to ona nie powie, dlaczego. To jest traktowane jako poronienie. Musi

14 Por. J. Balicki, E. Frątczak, Ch.B. Nam, Przemiany ludnościowe: fakty - interpretacje - opinie, tom 1: Mechanizmy przemian ludnościowych. Globalna polityka ludnościowa, Wydawnictwo Uniwersytetu Kardynała Stefana Wyszyńskiego, Warszawa 2003, s. 106. 
być tak traktowane, bo ona przychodzi $i$ roni (położna 3, 48 lat).

W polskich szpitalach rejestruje się ok. 40 tys. poronień samoistnych rocznie ${ }^{15}$. Przyczyna poronienia jest trudna do stwierdzenia, zwłaszcza we wczesnej ciąży (L4, L9, P3). W istocie nie wiadomo, jaki odsetek stanowi aborcja rozpoczęta w domu lub w gabinecie i zakończona w szpitalu jako poronienie. W latach 1989-1990, czyli w momencie dyskusji na temat dopuszczalności aborcji w Polsce, ginekolodzy z małego szpitala powiatowego odnotowali spadek przerwań ciąży, odpowiednio z 74 do 19, natomiast dwukrotnie wzrosła liczba poronień samoistnych z 48 do $85^{16}$. Zdaniem jednej z położnych (P5), takich przypadków jest wiele, ale nie jest to zjawisko masowe. Inna położna określiła, że w jej klinice takich "ciąż obumarłych” rejestruje się 150 na 2 tys. poronień rocznie (P3).

Ja myślę, że wśród tych poronień samoistnych rejestrowanych w szpitalach może być spora część poronień, która nie jest samoistnymi poronieniami, wywołanymi. I czasami być może poczatek, nawet $z$ udziałem lekarzy, one moga być wywołane i umowa jest taka, że ja pani dam taki $i$ taki lek, czy wykonam taka i taka procedure, a jakby pani poroniła, to pani idzie do szpitala $z$ tym. Tak że ta osoba sama tego nie dokonuje, ale powoduje, że następuje poronienie. Taka rzecz może mieć miejsce, ale żeby to ocenić, jak często to wystepuje, to nie jest łatwa sprawa (lekarz genetyk 9, 67 lat).

Nazewnictwo rozpoznań określa Międzynarodowa Statystyczna Klasyfikacja Chorób i Problemów Zdrowotnych (ICD-10). Terminy są dostosowane do norm prawnych w danym kraju, a w Polsce zabiegi można klasyfikować jedynie jako „przerwanie ciąży” i "poronienie”

15 Por. Sprawozdanie Rady Ministrów z wykonania w roku 2003 Ustawy z dnia 7 stycznia 1993 r. o planowaniu rodziny, ochronie płodu ludzkiego $i$ warunkach dopuszczalności przerywania ciązy (Dz. U. z 1993 r. Nr 17 poz. 78 z późn. zm.), Warszawa 2005, Biblioteka Sejmowa, V Kadencja, Druk nr 3395.

16 Por. A. Kulczycki, The Abortion Debate in the World Arena, Macmillan Press, London 1999, s. 116. 
(termin „aborcja” nie występuje w nazewnictwie prawno-medycznym).

Dawniej to była aborcja, a teraz, odkad sa te nowoczesne tabletki, to już nie. To sa już sporadyczne przypadki, że lekarz bierze ja do siebie do gabinetu i po prostu robi jej podczas dyżuru aborcję. Zależy, kto pisze te dokumentację. Potem ta dokumentacja przychodziła czyściusieńka, ważne, że kobieta przychodzi na dyżur tego konkretnego lekarza. I tylko się pisze: 'poronienie w toku'. Ale lekarz się czuje lepiej, bezpieczniej, jeśli ona przyjdzie do szpitala (lekarz 4, 48 lat).

Na oddziałach kluczowym zagadnieniem jest stosunek personelu do aborcji i do samych procedur. Już na początku lat 90. XX w. jeden ze znanych profesorów opowiadał się za dokonywaniem przerwań ciąży i rejestrowaniem ich jako poronień i to wbrew części środowiska lekarskiego i stanowisku Kościoła katolickiego ${ }^{17}$. Pewien ginekolog, kierownik kliniki, tak odniósł się do tej sprawy:

Pan profesor Dec, który - świętej pamięci - już nie żyje, mówit, że on nawet rozumiał tych lekarzy, którzy przerywaja ciąże, a wpisuja w rozpoznaniu 'poronienie samoistne'. Również pani Nowicka wypowiadała taki poglad, że fałszowanie zaświadczeń czy fałszowanie rozpoznań jest jakby usprawiedliwione w tym okresie ucisku, jaki jest teraz. Uważam to za naganne. Przypuszczam, że sa szpitale, w których taka popołudniowa aborciarnia funkcjonuje. Ile takich szpitali jest i jak to się odbywa? To prawdopodobnie sa szpitale, gdzie decyduje ordynator jednoosobowo siła autorytetu (lekarz 3, 59 lat).

\section{Aborcja z powodu wady płodu}

Warto zwrócić uwagę na okoliczności wykonywania zabiegów w ramach istniejących przepisów ustawy z 1993 r. Aborcja jest dopuszczalna w przypadku, gdy zagrożone jest życie lub zdrowie kobiety, w przypadku ciąży powstałej w wyniku czynu zabronionego (gwałtu), ale

17 Por. J. Heinen, A. Matuchniak-Krasuska, Aborcja w Polsce: kwadratura koła, Polskie Towarzystwo Religioznawcze, Warszawa, s. 37. 


\section{Część I}

Współczesna sytuacja demograficzna w Polsce

takie zabiegi rejestruje się rzadko. Jak wynika z danych urzędowych, najczęściej wykonuje się zabiegi, gdy matka dowiaduje się o upośledzeniu umysłowym lub poważnym uszkodzeniu organizmu dziecka ( $\mathrm{zw}$. aborcja eugeniczna). Z powodu takich chorób i wad genetycznych w 2012 r. zarejestrowano 701 na 752 przerwań ciąży, czyli $93 \%{ }^{18}$. Pewien lekarz, asystent kierownika, podał dane kliniki, w której dokonywano około „trzech zabiegów tygodniowo" (L4), czyli przeciętnie 150 rocznie. Wówczas, w 2003 r. zarejestrowano tylko 112 zabiegów z wymienionego powodu ${ }^{19}$. Informacja ta oznaczała, że tylko w tej klinice liczba zabiegów przekroczyła statystykę ogólnopolską prawie o jedną trzecią. Inni lekarze potwierdzili istnienie takich rozbieżności (L8, L9). Także położna z tej kliniki potwierdziła ${ }^{20}$, że istnieją praktyki zaniżania oficjalnych danych.

Aborcja w wyniku wady rozwojowej lub genetycznej płodu musi być poprzedzona odpowiednimi badaniami i uzyskaniem skierowania od lekarza specjalisty. W czasie prowadzenia wywiadów w Warszawie, takie prenatalne badania prowadził ośrodek ogólnie znany w Polsce i działa on do dziś. Jego kierownik nieco szerzej wyjaśniał okoliczności takiej aborcji:

Sa takie obszary, tereny w Polsce, że niektórzy lekarze po prostu nie kieruja na badania prenatalne, odmawiaja badań prenatalnych. Ale u mnie na przykład jest tak, że jak przyjdzie pani i mówi, że chciałaby sobie takie badania wykonać i ja wiem, że ona ma wskazania do tych badań, i mówi, że niestety odmówiono jej skierowania na takie badanie, to ja mówię: 'prosze mi to napisać, że była pani tu i tu, w tej przychodni, że prosiła pani

18 Por. Sprawozdanie Rady Ministrów z wykonania w roku 2012 Ustawy z dnia 7 stycznia 1993 r. o planowaniu rodziny, ochronie płodu ludzkiego i warunkach dopuszczalności przerywania ciąży (Dz.U.1993, Nr 17, poz.78 z późn. zm.), <http://orka.sejm.gov.pl/Druki7ka.nsf>, (dostęp: 21.02.2015).

19 Por. Sprawozdanie Rady Ministrów z wykonania w roku 2003 Ustawy z dnia 7 stycznia 1993 r. o planowaniu rodziny, ochronie płodu ludzkiego i warunkach dopuszczalności przerywania ciąży (Dz. U. z 1993 r. Nr 17 poz. 78 z późn. zm.), Warszawa 2005, Biblioteka Sejmowa, V Kadencja, Druk nr 3395.

20 Rozmowa z 2014 r. 
o to skierowanie i pani tego skierowania nie wydano'. I ja na tej podstawie uważam to za skierowanie, takie oświadczenie pacjentki. Nie uważam, żeby ktokolwiek miat prawo w ten sposób postępować, tylko odnotowuje fakt, kto, kiedy, i traktuje to na równi ze skierowaniem (lekarz genetyk 9, 67 lat).

Zakład genetyki zawiera umowę na przerwania ciąży z klinika, do której kierowane są pacjentki. Na badania genetyczne decydują się prawie tylko te pacjentki lub mat$\dot{z}$ eństwa $i$ pary, które potencjalnie sa gotowe na przerwanie ciązy w przypadku stwierdzenia wady płodu (L9). W normalnym trybie lekarze nie wydają takich skierowań, nie chcąc podpisywać się pod procedurą z założenia prowadzącą do aborcji. Inny lekarz ginekolog miał odmienny pogląd w sprawie aborcji z omawianej przyczyny:

To nie sa takie duże problemy, natomiast jest kwestia wskazań ze względu na stan zdrowia, ciężkie uszkodzenie lub chorobe rozwijajacego sie płodu. To jest problem, dlatego, że tam jest taka sytuacja, że pytanie, która to z wad jest rzeczywiście taka wada, która będzie uniemożliwiała trwale człowiekowi po urodzeniu życie. Wiemy, że w tej chwili ludzie z zespołem Downa przy właściwym prowadzeniu moga nawet żyć 40 lat. $W$ medycynie nie ma nigdy tak, że coś jest czarne $i$ białe. Oto sa wskazania, oto już nie ma. Gdzieś jest takie miejsce, że sa troche wskazania a trochę nie ma (lekarz 1, 61 lat).

\section{Odmowa zabiegu}

Niektórzy ginekolodzy sprzeciwiają się wykonywaniu zabiegów. Lekarka pracująca we wspomnianej już klinice dokonującej aborcji mówi, że jej kierownik sam podejmuje decyzje o wykonywaniu zabiegów przez konkretnych lekarzy, ale szanuje indywidualne postanowienia dotyczace rezygnacji (L8). Lekarka, będąc zastępcą tego kierownika, podejmowała zupełnie inne decyzje:

Ponieważ nikt tego nie chce robić, kierownik kliniki zgodzit się na to, $\dot{z} e$ to jest u nas robione. I on na to wyraża zgode. Ja na to nie wyrażam zgody. W zwiazku z tym, miałam taka sytuacje, gdzie 
zgłosiła się pacjentka, która ma zespót genetyczny taki letalny. Dwadzieścia tygodni ciąży, połowa ciązy, gdzie dziecko wykazuje ruchy, gdzie rzeczywiście jest to problem. Zwróciła się o zgodę i ja jej nie wyraziłam. Wróciła do instytutu genetyki, genetyk poprosit, żebym napisała, że odmawiam (lekarka 8, 49 lat).

Lekarze odmawiają aborcji, korzystając z prawa do zwolnienia z obowiązku wykonania usługi z powodu przekonań (klauzula sumienia). Lekarka odmawia zabiegów tylko pod nieobecność ordynatora. Formalne przyczyny jej decyzji stanowią zawsze wskazania zdrowotne organizmu kobiety. Uważa, że w przypadku wystąpienia bezczaszkowia powinno się czekać do naturalnego zakończenia ciąży, czyli porodu. Pacjentki zdecydowane na wcześniejsze rozwiązanie ciąży przez aborcję są do niego przekonywane, mimo że zaraz potem może nastąpić śmierć dziecka. Czas do porodu lub tuż po nim umożliwia rodzicom podjęcie decyzji o chrzcie dziecka (płodowym), a po śmierci - odpowiednim pochówku i żałobie. W wydarzeniach uczestniczy kapelan szpitalny, a wszystko jest regulowane prawnie. W takim przypadku odmowa zabiegu przez lekarza nie jest motywowana tylko obawami o stan zdrowia matki, lecz także pewnym zaangażowaniem religijnym. Pozostali ginekolodzy i położne prawie nic nie mówili o swoim stosunku do religii, natomiast potwierdzają podobne rezygnacje $z$ aborcji na innych oddziałach, również w wyniku odpowiednich działań kapelanów i przy zaangażowaniu któregoś z lekarzy (L3, L4, L8, P2, P3). Opisane postępowanie lekarza w sprawie odmowy aborcji jest analogiczne do przykładu znanego profesora, byłego dyrektora szpitala położniczego w Warszawie, który postępował podobnie, korzystając z klauzuli sumienia ${ }^{21}$.

Jeden z lekarzy jest zdania, że indywidualna klauzula sumienia wynika nie tylko z przepisu prawa, ale raczej jest przejawem etyki lekarskiej, która obowiązuje nieza-

21 Por. B. Chazan, M. Müller, Prawo do życia. Bez kompromisu, z B. Chazanem rozmawia M. Müller, Wydawnictwo WAM, Kraków 2014. 
leżnie od zawirowań politycznych (L3). Kwestią trudną lecz niezbędna, jest rozmowa z każdą pacjentką o jej sytuacji rodzinnej, a nie tylko korzystanie ze „zbiorowej klauzuli” i traktowanie jej jak rozwiązania biurokratycznego. Pacjentka pozostawiona bez porady będzie szukać innego lekarza, który wykona aborcję za opłatą.

Ta klauzula jest to klauzula sumienia indywidualna. I teraz może powstać taki problem, że wszyscy lekarze w danym ośrodku łacznie z ordynatorem taka klauzule chca mieć. W swoim czasie dużo szpitali zadeklarowało publicznie, że nie wykonuje się żadnych zabiegów przerywania cią̇y, zwłaszcza na południu Polski (lekarz 3, 59 lat).

Opisana sytuacja odnosi się do kontekstu ostatniej dekady XX w., gdy rząd Sojuszu Lewicy Demokratycznej rozszerzył prawo aborcyjne (1996-97 r.). Wówczas wiele szpitali „na południu Polski” sprzeciwiło się tej zmianie i nie dokonywało aborcji, a raport rządowy z tamtego okresu wykazał bardzo niskie dane lub po prostu braki $\mathrm{w}$ rejestracji ${ }^{22}$. W istocie przez kilkanaście lat stan ten $\mathrm{w}$ tamtejszych szpitalach publicznych nie zmienił się do dziś i ordynatorzy oddziałów odmawiają aborcji ${ }^{23}$. Lekarz z województwa lubelskiego tak mówił:

Może tam zdesperowane osoby, które nie maja możliwości przede wszystkim ze względów finansowych, będa szukały możliwości wykonania zabiegu w szpitalu, ale nawet pacjentki niezamożne najpierw myśla o gabinecie prywatnym niż o szpitalu. (...) Pierwsza moja odpowiedź brzmi: 'przepraszam, ale ja zabiegów nie wykonuję. 'No, a gdzie pan mógłby mi doradzić', 'Nie wiem, nie jestem w stanie pani doradzić, ale, no proszę szukać takich możliwości. To jest pani sprawa'. Większa część osób odmówi na pewno ze względu na swoje przekonania. Część odmówi na pewno ze względu na to, że środowisko potępi takiego lekarza, presja społeczna $i$ tak dalej. Tak że szans na wykonanie

22 Por. Sprawozdanie Rady Ministrów z realizacji w roku 1997 ustawy z dnia 7 stycznia 1993 r. o planowaniu rodziny, ochronie płodu ludzkiego i warunkach dopuszczalności przerywania ciąży (Dz. U. z 1993 r. Nr 17 poz. 78 z późn. zm.), Warszawa 1998, Biblioteka Sejmowa, IV Kadencja, Druk nr 592.

23 W Rzeszowie działa niepubliczna klinika dokonująca aborcji, 2014. 
zabiegu w szpitalu ja nie widze specjalnie. Nikt. Może gdzieś tam (lekarz 5, 61 lat).

Życie w małym mieście oznacza brak anonimowości, dlatego żaden lekarz nie przyzna się do dokonywania aborcji. Kobiety z większymi problemami są kierowane do Lublina lub wyjeżdżają na Ukrainę. Z kolei w Warszawie, mimo pewnej łatwości znalezienia odpowiedniego gabinetu, ginekolodzy również odmawiają aborcji, zasłaniając się klauzulą sumienia, lecz nie określają tego tak kategorycznie jak w małym mieście:

Ja na pewno nie, ja się tym nie zajmuje. Natomiast znam adres, który mógłbym takiej pacjentce wskazać, mógłbym, ale też pod warunkiem, że ten ktoś w danej chwili się na to decyduje (lekarz 1, 61 lat).

Lekarz ten wypełnia prawo polskie obwarowujące klauzulę sumienia i nakazujące wskazać innego lekarza, który zrealizuje wymaganą usługę. Duże miasto sprzyja tego rodzaju zapewnieniom. Lecz nie wszyscy lekarze, z którymi rozmawiałem, odmawiają zabiegu szpitalnego i trzech na dziesięciu przyznało, że dokonują ich zgodnie z przepisami i warunkami ustawowymi.

Część kolegów z zespołu, mimo tego, że ustawa dopuszcza w pewnych sytuacjach przerwanie ciąży, nie robia tego, nie biora w tym udziatu, i moga sobie na to pozwolić. Ja to zrobię (lekarka 7, 44 lata).

Istnieje więc podział wśród lekarzy na dokonujących i niedokonujących aborcji. Dodatkowo postępowanie to określa hierarchia służbowa (zakazy zabiegów), ale też wzajemna znajomość umiejętności fachowych i poglądów w zespole lekarskim (L8). Gdy członkowie zespołu wiedza, kto wykonuje dane procedury, istnieje mniejsza możliwość dezinformacji. Kwestia pewnej otwartości działań dotyczy także wiedzy, kto i jakie procedury wykonuje nieformalnie. 


\section{Zakończenie}

Aborcja jest wykonywana coraz częściej z zastosowaniem leków. W szpitalach notuje się ją jako poronienie samoistne, ukrywając prawdziwą jej genezę. Dlatego dzisiaj zjawisko to bardzo trudno rzetelnie oszacować, a także - bez świadomości istnienia wielostronnego podziemia aborcyjnego - nie można prowadzić jednolitej polityki wobec rodziny. Tym bardziej, że coraz więcej usług w polskiej służbie zdrowia prowadzi się bez prawnego uregulowania (pigułka po stosunku, in vitro). Biurokratyczny system skierowań działa tak szczelnie, że wiele aborcji realizuje się poza nim za opłatą. Ważne, aby lekarze korzystający z indywidualnej klauzuli sumienia nie pozostawiali jednocześnie kobiet i ich rodzin bez wszechstronnej porady i wsparcia.

Ginekolodzy są zdania, że niewielu lekarzy zajmuje się dzisiaj aborcja ponieważ kolejne zmiany przepisów karnych wymusiły fale rezygnacji z jej prowadzenia. Czynnikiem powodującym mniejsze niż kiedyś zapotrzebowanie na tradycyjną aborcję jest popularność środków antykoncepcyjnych. Przyczynił się do tego rozwój rynku farmaceutycznego, a owe zmiany w Polsce miały swój początek właśnie wtedy, gdy wprowadzano przepisy ograniczające dostęp do aborcji. W latach 1992-2003 sprzedaż wartościowa doustnych środków antykoncepcyjnych wzrosła z 2,21 mln do 189,7 mln złotych, czyli o 86 razy $^{24}$. Ponadto cykliczne ogólnopolskie badania społeczne na temat regulacji poczęć wykazują coraz większy odsetek kobiet i mężczyzn wybierających raczej pigułkę antykoncepcyjną lub prezerwatywę niż pozostałe metody zapobiegania ciąży, w tym kalendarzyk małżeński i stosunek przerywany ${ }^{25}$.

\footnotetext{
$24 \quad$ Informacja własna uzyskana od IMS Health Poland, Warszawa 2004.

25 Por. Stan zdrowia ludności Polski w 2009 r., Główny Urząd Statystyczny, Warszawa 2011, s. 78-79, <http://stat.gov.pl/obszary-tematyczne/zdrowie/zdrowie/stan-zdrowia-ludnosci-polski-w-2009-r,6,5.html>, (dostęp: 21.02.2015).
} 


\title{
Część I
}

Współczesna sytuacja demograficzna w Polsce

Lekarze potwie rzepisują pigułki antykoncepcyjne bardzo młodym dziewczętom, ponieważ są one dla nich pewniejsze niż jakiekolwiek metody naturalne. Popularną metodą uniknięcia ciąży jest tabletka po stosunku seksualnym. Część ginekologów uważa ją za preparat wczesnoporonny, nie zalecając jej, lecz inni są zdania, że jest ona bardzo skuteczna w nagłych sytuacjach. Z tabletki najczęściej korzystają osoby bardzo młode, uczące się, niezamężne i przed urodzeniem pierwszego dziecka. Sprzedaż roczna w 2004 r. wynosiła ok. 100 tys. opakowań ${ }^{26}$. Tylko cztery osoby badane same propagują naturalne metody planowania rodziny, które są zalecane przez Kościół.

\section{Abortion in the perception of the medical staff}

\begin{abstract}
The article discusses a research on abortion, which was conducted as in-depth interviews with 18 gynaecologists and midwives in Warsaw and Lubartów, Lubelskie voivodeship. The purpose of this qualitative research was to understand the activities of medical personnel in the organization of abortion and to answer the question of why hospitals record a few abortions when different non-government organizations inform with a large underground abortion. The study proves that traditional treatments in private clinics are replaced by pharmacological abortion and increasingly disappear for the use of contraceptives and pill after. The widespread use of the drug causes abortion in hospitals is recorded as a miscarriage, and the official number of treatments is underestimated. Therefore, formal procedures are shifted to abortion underground. Doctors refuse to perform the surgery their patients explaining that they use the conscience clause and but only some of them conduct long medical interviews trying
\end{abstract}

26 Informacja własna od koncernu Gedeon Richter, który rozprowadzał tabletki Postinor-duo. 


\section{Część I}

Współczesna sytuacja demograficzna w Polsce

to convince the birth of child. The interview is very difficult in the case of mental disability or irreversible defect of foetus. The article presents the circumstances obtaining referrals for abortion in a clinic that performs treatments. 



\section{Kinga Łapczys}

\section{Polskie podziemie aborcyjne: stan prawny - stan faktyczny}

\section{Wprowadzenie}

7 stycznia 1993 roku uchwalono w Polsce Ustawe o planowaniu rodziny, ochronie płodu ludzkiego $i$ warunkach dopuszczalności przerywania ciąży, która w stosunku do ustawy z 1956 roku zniosła możliwość dokonywania aborcji z przyczyn społecznych. Fakt ten traktowany jest przez środowiska pro-life jako wielki sukces, gwarantujący ochronę życia poczętego w naszym kraju. Mówi się wprawdzie o istnieniu podziemia aborcyjnego, ale wyraźnie jest ono marginalizowane. Na poruszaniu tego tematu zależy środowiskom pro-choice, które chcą podważać skuteczność obecnej ustawy i doprowadzić do jej zmiany. Zdaniem działaczy ruchów ochrony życia poczętego liczba przerwanych ciąż w podziemiu aborcyjnym w Polsce waha się w granicy kilku tysięcy, a zdaniem zwolenników dopuszczalności aborcji sięga kilkuset tysięcy rocznie.

Szacunki ruchów pro-choice są prawdopodobnie zawyżone, ale z kolei pro-life są na pewno mocno zaniżone. Trudno jednak ocenić wielkość podziemia aborcyjnego. Można stwierdzić, że działacze ruchów antyaborcyjnych skupiają się przede wszystkim na utrzymaniu obecnego stanu prawnego, co sprawia, że nie podejmują działań na rzecz weryfikacji skuteczności obowiązującej ustawy.

Niniejszy artykuł nie rozstrzyga problemu liczby nielegalnie wykonywanych aborcji w Polsce, ale ma na celu próbę odpowiedzi na pytanie o skuteczność regulacji prawnych dotyczących możliwości przerywania ciąży, poprzez sprawdzenie stopnia trudności dostępu do usług aborcyjnych. Artykuł przedstawia wyniki badań, w któ- 


\section{Część I}

Współczesna sytuacja demograficzna w Polsce

rych analizowano ogłoszenia sugerujące świadczenie usługi przerywania ciąży oraz wykonano rozmowy telefoniczne z ogłoszeniodawcami.

\section{Regulacje prawne aborcji w Polsce}

W XX w. w wielu państwach podjęto próbę regulacji prawnych nt. przerywania ciąży. Między innymi w ZSRR w 1920 r. uregulowano możliwość dokonywania legalnej aborcji, czy w Islandii w 1938

r. W Polsce zagadnienie to podjęto w latach 30. XX w. w Kodeksie karnym. Uchwalony w 1932 r. dokument zezwalał na aborcję, gdy ciąża powstała w wyniku gwałtu, kazirodztwa, nadużycia, stosunku z osobą niepoczytalną oraz problemów zdrowotnych zagrażających życiu matki. Jednak ten stan prawny nie trwał długo. Już podczas II wojny światowej sytuacja uległa zmianie ${ }^{1}$.W 1942 r. Adolf Hitler wyraził swoje poparcie dla wykonywania aborcji, co następnie znalazło wyraz w wydanym 9 marca 1943 r. rozporządzeniu. Akt prawny regulował możliwość legalnego przerywania ciąży przez Polki, jednocześnie podkreślając zakaz spędzania płodu wśród obywatelek Niemiec². Rozporządzenie to przestało obowiązywać wraz z końcem wojny, kiedy powrócono do wcześniejszych uregulowań prawnych. Ówczesne regulacje prawne zostały utrzymane aż do 1956 r., kiedy to pod wpływem prawodawstwa radzieckiego wprowadzono w Polsce ustawę z dnia 27 kwietnia 1956 r. o warunkach dopuszczalności przerywania ciąży. Podkreślono, że jej celem jest ochrona zdrowia kobiety przed ujemnymi skutkami zabiegów przerywania cią̇̇y, dokonywanych w nieodpowiednich warunkach lub przez osoby

Por. T. Pietrzykowski, Etyczne problemy prawa, Naukowa. Oficyna Wydawnicza., Katowice 2005, s. 243-244; J. Puzewicz-Barska, M. Tarasiewicz, Nasze ciała nasze życia, wyd. Stowarzyszenie Współpracy Kobiet, Gdańsk 2004, s. 397.

2 Por. A. Zięba, Historia legalizacji aborcji w Europie $i$ w Polsce. Ludobójcy Lenin i Hitler jako pierwsi w Europie zalegalizowali aborcje, <blog.pro-life. pl/opracowania/historia-legalizacji-aborcji/>, (dostęp: 17.08.2012). 
nie będace lekarzami ${ }^{3}$. Prawodawca do wspomnianych wcześniej przesłanek uprawniających do przerwania ciąży (czyn zabroniony oraz zagrożenie życie) dodał kolejna, czyli trudne warunki życiowe kobiety ciężarnej. Stwierdzono także, że ciąża mogła zostać przerwana ze względu na tę przesłankę po wcześniejszym złożeniu lekarzowi pisemnego oświadczenia o chęci dokonania aborcji. W innych przypadkach zainteresowana musiała uzyskać od lekarza orzeczenie o występowaniu jednej z dozwolonych przesłanek. Szacuje się, że aborcje, których podstawą była przesłanka społeczna stanowiły ok. 99\% ogółu przerwanych ciąży w latach obowiązywania ustawy ${ }^{4}$.

Wraz ze zmianami społecznymi i mentalnymi, jakie miały miejsce w lat 70. XX wieku w Polsce, rozpoczęto intensywną polemikę nad słusznością zapisów aborcyjnych. Wówczas środowiska związane z Kościołem katolickim, później określane mianem pro-life, podjęły liczne działania na rzecz zmiany istniejącego prawa. W 1970 r. Episkopat Polski wystosował list do władz PRL, w którym przekazano informację o ok. milionie wykonywanych aborcji w ciągu roku oraz o potrzebie pokuty, modlitwy i ofiary w obronie życia ludzkiego od poczęcia ${ }^{5}$. Inne działania podejmowane były m.in. przez Karola Wojtyłę, który był organizatorem licznych spotkań środowisk naukowych i medycznych mających na celu wymianę poglądów oraz poszerzanie wiedzy w temacie antykoncepcji i przerywania ciąży. Koniec lat 80. i początek lat 90. XX w. to czas kształtowania się ruchów pro-choice, które postulowały możliwość legalnego przerywania ciąży, oraz pro-life opowiadających się za zakazem przerywania ciążý.

3 Ustawa z dnia 27 kwietnia 1956 r. o warunkach dopuszczalności przerywania ciaży, <http://isap.sejm.gov.pl/DetailsServlet?id=WDU19560120061>, (dostęp: 18.04.2014).

4 Por. W. Bołoz, Bioetyka i prawa człowieka, Wyd. Uniwersytetu Kardynała Stefana Wyszyńskiego, Warszawa 2007, s. 113.

5 Por. 27 kwietnia - Narodowym dniem pokuty za grzechu przeciwko życiu człowieka, <http://blog.pro-life.pl/27-kwietnia-narodowym-dniem-pokutyza-grzechy-przeciwko-zyciu-czlowieka-2/>, (dostęp: 18.04.2014).

6 Por. E. Wejbert-Wąsiewicz, Kontrola urodzeń w Polsce - ideologia i polityka 


\section{Część I}

Współczesna sytuacja demograficzna w Polsce

Dnia 7 stycznia 1993 r. uchwalono Ustawe o planowaniu rodziny, ochronie płodu ludzkiego i warunkach dopuszczalności przerywania cią̇y, w której zakazano aborcji ze względów społecznych. W obliczu ożywionej debaty ws. zapisów prawnych, lewicowy parlament przyjął w 1996 r. poprawki łagodzące dotychczasowe uregulowania. Przeciwnikiem tych zmian był ówczesny prezydent Lech Wałęsa, który zawetował akt. Jednak niedługo potem jego następca Aleksander Kwaśniewski podpisał wypracowany dokument. Do art. 4 ustawy dodano ustęp czwarty brzmiący kobieta ciężarna znajduje się w ciężkich warunkach życiowych lub trudnej sytuacji osobistej, co w praktyce oznaczało możliwość dokonania aborcji na żądanie kobiety. Za sprawą grupy senatorów RP decyzja ta została zaskarżona do Trybunału Konstytucyjnego. 28 maja 1997r.orzekłonniezgodnośćzapisów ustawy z Konstytucją RP. Decyzję uzasadniono konstytucyjnym prawem ochrony życia, a w szczególności zasadami demokratycznego państwa prawa. Dodano również, że nie można różnicować fundamentalnego dobra człowieka, jakim jest ludzkie życie. Brak odpowiednich kryteriów do dokonania zróżnicowania sprawia, że ludzkie życie powinno być chronione od momentu poczęcia. Warto dodać, że ratyfikowana przez Polskę w 1991 r. Konwencja Praw Dziecka podkreśla, iż dziecko wymaga szczególnej opieki, troski i właściwej ochrony prawnej przed, jak i po urodzeniu ${ }^{7}$. Wówczas przywrócono początkowe zapisy prawne. W późniejszym okresie powstały projekty modyfikacji ustawy, jednak

a praktyka społeczna, <http://realia.com.pl/dzial_6/artykul_175.html, s. 43>, (dostęp: 15.07.2012); T. Pietrzykowski, dz. cyt., s. 251; W. Nowicka, Walki o legalna aborcje i przeciw niej, w: Rzecznictwo w sprawie dostepności przerywania ciąży: studium jedenastu krajów, red. B. Klugman, D. Budlender, The Women's Health Project, Warszawa 2001, s. 75.

7 Por. W. Nowicka, Ustawa antyaborcyjna w Polsce - stan prawny i rzeczywisty, w: Prawa reprodukcyjne w Polsce. Skutki ustawy antyaborcyjnej, red. W. Nowicka, Federacja na Rzecz Kobiet i Planowania Rodziny, Warszawa 2007, s. 19; J. Balicki, E. Frątczak, Ch. B. Nam, Przemiany Ludnościowe. Fakty - Interpretacje - Opinie, Wyd. Uniwersytetu Kardynała Stefana Wyszyńskiego, Warszawa 2007, s. 373; W. Bołoz, dz. cyt., s. 115; T. Pietrzykowski, dz. cyt., s. 254. 


\section{Część I}

Współczesna sytuacja demograficzna w Polsce

żaden z nich nie spowodował zmian w obowiązującym prawie. Taką próbę podjęła m.in. Liga Polskich Rodzin w 2006 r., która apelowała o dodanie do art. 38 Konstytucji słów o ochronie życia ludzkiego „od poczęcia do naturalnej śmierci" ${ }^{\prime}$.

Poniżej umieszczono tabelę przedstawiającą statystykę wykonywanych aborcji w latach 1965-2010. Aż do 2001 r. liczba przerwanych ciąż systematycznie spadała, z wyjątkiem 1997 r., kiedy zezwolono na legalną aborcję z przyczyn społecznych. W ostatnich latach odnotowuje się wzrost liczby legalnie przerwanych ciąż.

Tabela 1. Liczba leganie przerwanych ciąż w szpitalach publicznych w latach 1965-2011

\begin{tabular}{|c|c|c|c|}
\hline Rok & Liczba aborcji & Rok & Liczba aborcji \\
\hline 1965 & 168587 & 1993 & 1240 \\
\hline 1970 & 148219 & 1994 & 782 \\
\hline 1975 & 138634 & 1995 & 559 \\
\hline 1976 & 140909 & 1996 & 505 \\
\hline 1977 & 143486 & 1997 & 3047 \\
\hline 1978 & 145630 & 1998 & 310 \\
\hline 1979 & 140695 & 1999 & 151 \\
\hline 1980 & 137950 & 2000 & 138 \\
\hline 1981 & 132894 & 2001 & 124 \\
\hline 1982 & 138977 & 2002 & 159 \\
\hline 1983 & 130980 & 2003 & 174 \\
\hline 1984 & 132844 & 2004 & 193 \\
\hline 1985 & 135564 & 2005 & 225 \\
\hline 1986 & 129716 & 2006 & 340 \\
\hline 1987 & 123534 & 2007 & 322 \\
\hline 1988 & 105333 & 2008 & 499 \\
\hline 1989 & 82137 & 2009 & 538 \\
\hline
\end{tabular}

8 Por. W. Nowicka, Polskie zmagania o aborcje, <http://www.przestrzeniedialogu.org/download/drogi_rownosci_nowicka.pdf>, s. 35, (dostęp: 11.07.2012). 
Współczesna sytuacja demograficzna w Polsce

\begin{tabular}{|l|l|l|l|}
\hline 1990 & 59417 & 2010 & 641 \\
\hline 1991 & 30878 & 2011 & 669 \\
\hline 1992 & 11640 & 2012 & 752 \\
\hline
\end{tabular}

Źródło: E. Wejbert-Wąsiewicz, Kontrola urodzeń w Polsce - ideologia i polityka a praktyka społeczna, <http://realia.com.pl/pdf/2_2009/05_02_2009.pdf>, s. 50, (dostęp: 15.07.2012); Rada Ministrów, Sprawozdanie Rady Ministrów z wykonywania oraz o skutkach stosowania w roku 2012 ustawy z dnia 7 stycznia 1993 roku o planowaniu rodziny, ochronie płodu ludzkiego i warunkach dopuszczalności przerywania ciaży, <http://orka.sejm.gov.pl/Druki7ka.nsf/0/C170D861FC5D4A3AC1257C680033A257/\%24File/2067.pdf>, Warszawa 2014, s. 78 (dostęp: 15.07.2014).

Obowiązująca ustawa zezwala na legalne przerwanie ciąży w szpitalach państwowych w trzech przypadkach. Przesłanki wskazane zostały $\mathrm{w}$ art. 4a ustawy, a należą do nich: ciąża zagrażająca życiu lub zdrowiu matki, ciężkie i nieodwracalne prawdopodobieństwo upośledzenia płodu oraz ciąża powstała w wyniku czynu zabronione$\mathrm{go}^{9}$. Ustawa miała stanowić kompromis między środowiskiem pro-life i pro-choice poprzez ogólny zakaz aborcji, a jednoczesne zezwolenie na nią w kilku przypadkach. Dodatkowo Rada Ministrów zobowiązana została do sporządzania corocznych raportów z wykonywania i skutków ustawy.

Pierwszy przypadek pozwalający na legalną aborcję dotyczy ciąży zagrażającej życiu kobiety. Zaistnienie tej okoliczności musi być potwierdzone przez lekarza, jednak ostateczna decyzja dotycząca przebiegu ciąży należy do kobiety. W tym przypadku aborcja musi być przeprowa-

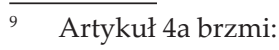

"1. Przerywanie cią̇̇y może być dokonane wyłacznie przez lekarza w przypadku, gdy:

1) ciąża stanowi zagrożenie dla życia lub zdrowia matki ciężarnej,

2) badania prenatalne lub inne przesłanki medyczne wskazuja na duże prawdopodobieństwo ciężkiego i nieodwracalnego upośledzenia płodu albo nieuleczalnej choroby zagrażającej jego życiu,

3) zachodzi uzasadnione podejrzenie, że ciaża powstała w wyniku czynu zabronionego."

Ustawa z dnia 7 stycznia 1993 r. o planowaniu rodziny, ochronie płodu ludzkiego $i$ warunkach dopuszczalności przerywania cią̇y,: <http://isap.sejm.gov.pl/ DetailsServlet?id=WDU19930170078>, s. 1, (dostęp: 17.07.2012). 
dzona przez innego lekarza niż tego, który wydał oświadczenie o spełnianiu tej przesłanki. Nieco inaczej uregulowane są przypadki bezpośredniego zagrożenia życia lub zdrowia ciężarnej, gdyż w takich okolicznościach aborcji może dokonać ten sam lekarz. Artykuł ten jest niedookreślony, co pozwala na swobodne podejmowanie decyzji przez lekarza o tym, co należy zakwalifikować jako zagrożenie życia lub zdrowia kobiety. Dodatkowo aborcja może być dokonana jedynie do 12 tygodnia ciąży.

Drugi przypadek wymieniony w ustawie dotyczy prawdopodobieństwa upośledzenia płodu. W zapisie prawnym użyto słów "duże prawdopodobieństwo" świadczących o tym, że wystarczą podejrzenia wad rozwojowych, aby dokonać legalnej aborcji. Konieczna jest jednak opinia lekarza o nieprawidłowościach w rozwoju płodu. W tym przypadku prawodawca nie określił maksymalnego czasu trwania ciąży do wykonania aborcji.

Ostatni przypadek dotyczy ciąż powstałych w wyniku czynu zabronionego. Przesłankę tę regulują również zapisy Kodeksu karnego. Wśród nich wyróżnia się gwałt, kazirodztwo, czynności seksualne z osobą poniżej 15. roku życia, czy wykorzystania seksualne osób bezradnych i upośledzonych. Podobnie jak w przypadku zagrożenia życia lub zdrowia, kobieta może zdecydować się na aborcję do 12 tyg. ciąży. W poniższej tabeli zaprezentowano liczbę aborcji wykonanych w latach 2002-2010 ze względu na wymienione przesłanki. 
Tabela 2. Oficjalne dane nt. przerwanych ciąż w latach 2002-2010

\begin{tabular}{|c|c|c|c|}
\hline \multirow{2}{*}{ Rok } & \multicolumn{3}{|c|}{ Przerwanie ciąży dokonane zgodnie z } \\
& $\begin{array}{c}\text { Z powodu } \\
\text { zagrożenia } \\
\text { życia lub } \\
\text { zdrowia } \\
\text { matki }\end{array}$ & $\begin{array}{c}\text { W wyniku } \\
\text { upośledzenia } \\
\text { płodu }\end{array}$ & $\begin{array}{c}\text { W wyniki } \\
\text { czynu zabro- } \\
\text { nionego }\end{array}$ \\
\hline 2002 & 71 & 82 & 6 \\
\hline 2003 & 59 & 112 & 3 \\
\hline 2004 & 62 & 128 & 3 \\
\hline 2005 & 54 & 168 & 3 \\
\hline 2006 & 82 & 246 & 12 \\
\hline 2007 & 37 & 282 & 3 \\
\hline 2008 & 32 & 467 & 0 \\
\hline 2009 & 27 & 510 & 1 \\
\hline 2010 & 27 & 614 & 0 \\
\hline 2011 & 49 & 620 & 0 \\
\hline 2012 & 50 & 701 & 1 \\
\hline
\end{tabular}

Źródło: Rada Ministrów, Sprawozdanie Rady Ministrów z wykonywania oraz o skutkach stosowania w roku 2012 ustawy z dnia 7 stycznia 1993 roku o planowaniu rodziny, ochronie płodu ludzkiego i warunkach dopuszczalności prz erywania ciąży, <http://orka.sejm.gov.pl/Druki7ka.nsf/0/C170D861FC5D4A3AC1257C680033A257/\%24File/2067.pdf >, Warszawa 2014, s. 78 (dostęp: 15.07.2014).

Omówione przesłanki plasują Polskę, podobnie jak Hiszpanię, czy Luksemburg, w grupie państw ustanawiających warunki kwalifikujące kobietę do legalnej aborcji. Inne grupy stanowią państwa całkowicie zakazujące przerywania ciąży (np. Malta) oraz te, w których występuje aborcja na żądanie kobiety. Do ostatniej grupy należą m.in.: Austria, Belgia, Czechy, Estonia, Bułgaria, Dania, Francja, Finlandia, Grecja, Włochy, Słowacja, Szwecja, Węgry, Hiszpania, czy Wielka Brytania. Oczywiście w każdym państwie występują dodatkowo inne przesłanki do usunięcia ciąży. Na przykład na Litwie i Łotwie 
kobiety mogą dokonać aborcji po 12 tygodniu trwania ciąży w przypadku śmierci męża, a także w przypadku przebywania w więzieniu ciężarnej lub ojca dziecka. Warto wspomnieć, że różne regulacje prawne w państwach przyczyniły się do powstania tzw. turystyki aborcyjnej. Polega ona na zorganizowanych lub indywidualnych wyjazdach do innych państw w celu usunięcia ciąży. Zjawisko to jest szczególnie widoczne w przypadku państw o zaostrzonych przepisach prawnych nt. aborcji. Wybór państwa najczęściej podyktowany jest m.in. łącznością komunikacyjna, cena, warunkami oraz nienaruszaniem obowiązującego w danym państwie prawa.

Polska ustawa regulująca przerywanie ciąży jest bardzo restrykcyjna w porównaniu do innych państw europejskich. Zmiana prawa spowodowała, że kobiety zainteresowane dokonaniem aborcji szukały alternatywnych możliwości, w wyniku czego zaczęło powstawać tzw. podziemie aborcyjne. Dla zwolenników ruchów pro-life podziemie aborcyjne to miejsce krzywdzące kobiety i nienarodzone dzieci. Inaczej uważają środowiska pro-choice, według których podziemie aborcyjne pozwala kobietom decydować o własnym ciele i życiu. Ruchy przedstawiają odmienne liczby nielegalnie wykonywanych aborcji. Przeciwnicy przerywania ciąży szacują, że wynosi ona od 7008 do 14321 aborcji1 $^{10}$. Zupełnie inne dane przedstawiają organizacje pro-choice. Według danych Federacji na Rzecz Kobiet i Planowania Rodziny przerywa się od 139000 do 279000 ciąż rocznie ${ }^{11}$. Dotychczas nie powstały jednak żadne badania określające dokładnie liczbę nielegalnych aborcji. Z całą pewnościa, można jednak stwierdzić, że w Polsce występuje podziemie aborcyjne, co zostanie przedstawione w dalszej części artykułu.

10 Por. J. Deszcze, M. Stachura, B. Trzcińska, J. Wronicz, Podziemie aborcyjne mity i fakty, <www.wychowawca.pl/miesięcznik/3_135/18.html>, (dostęp: 17.08.2012).

11 Por. W. Nowicka, Ustawa antyaborcyjna w Polsce, dz. cyt., s. 22-31. 


\section{Metodyka badań nt. przerwania ciąży}

Dotarcie do ogłoszeń oferujących aborcję nie stanowi problemu. Codziennie w gazetach i na stronach internetowych ukazuje się wiele anonsów sugerujących świadczenie usługi przerywania ciąży. Wielu ogłoszeniodawców nie używa w nich bezpośrednio słów takich jak aborcja, a przedstawia swoją ofertę tak, aby nie wskazywała na propozycję wykonania nielegalnego czynu. Wśród popularnych określeń używanych przez lekarzy należy wyróżnić „pełen zakres usług” oraz „przywracanie cyklu/miesiączki”.

Badania przeprowadzone zostały na podstawie ogłoszeń zamieszczonych w gazecie Oferta" Warszawska Gazeta Bezpłatnych Ogłoszeń. Analizie poddane zostały gazety z lutego i marca 2012 roku, o numerach 1753, 1756, 1759 oraz 1765, a następnie ogłoszenia zamieszczone na stronie internetowej gazety z dnia 17.08.2012, 23.08.2012, 31.09.2012 oraz 05.09.2012. Dodatkowo w tych samych dniach wzięto pod uwagę ogłoszenia ze strony internetowej dla innych regionów kraju. Gazeta została wybrana jako materiał badawczy dlatego, że jest ona jedną z największych gazet ogłoszeniowych w kraju.

Ostatnią częścią badań były wywiady telefoniczne, które przeprowadzone zostały we wrześniu 2012 r. Wybór ogłoszeń, które następnie zostały poddane sprawdzeniu telefonicznemu miał charakter próby celowej. Wywiady telefoniczne zostały przeprowadzone $\mathrm{w}$ dniach 5 i 6 września 2012 r. Łącznie wykonano 15 prób nawiązania kontaktu telefonicznego $\mathrm{z}$ ogłoszeniodawcami. Ostatecznie rozmowy przeprowadzone zostały z 11 osobami, a z jedną osobą wymiana wiadomości sms. Jedna $\mathrm{z}$ tych rozmów przeprowadzona była przez mężczyznę w celu sprawdzenia, czy usługa dostępna jest jedynie dla kobiet, czy też można otrzymać lek w przypadku aborcji farmakologicznej lub umówić się na zabieg w przypadku aborcji chirurgicznej bez bezpośredniego kontaktu kobiety z lekarzem. Z trzema ogłoszeniodawcami nie udało się nawiązać kontaktu telefonicznego. Przeprowadzając wy- 
wiady, podawano się za 23- lub 24-letnią kobietę we wczesnej fazie ciąży, a mężczyzna przedstawił się jako partner kobiety w ciąży. Podczas wywiadów starano się uzyskać informacje takie jak cena, termin, czy metoda aborcji oraz możliwe powikłania.

\section{Analiza prasowych i internetowych ogłoszeń aborcyj- nych}

W każdym badanym numerze gazety znajdowało się kilka ogłoszeń sugerujących świadczenie usługi aborcji. Wśród nich wiele określanych jest jako „przywracanie cyklu/miesiączki”, , pełen zakres usług”, czy "farmakologicznie, profesjonalnie, tanio". We wspomnianej gazecie znajduje się rozdział "Zdrowie”, a następnie kategoria usługi, gdzie można znaleźć ogłoszenia lekarzy oferujących aborcję. W numerze 1753 gazety z dnia 27.02.2012 r. znajdowało się 11 ogłoszeń, w kolejnym (1756) z dnia 05.03.2012 było ich 6. W dwóch następnych gazetach (1759 i 1765) z dnia 12.03.2012 oraz 26.03.2012 znajdowało się odpowiednia 5 i 8 ogłoszeń. Przywołane dane wskazuja, że nie występuje stała tendencja umieszczania ogłoszeń aborcyjnych, można jednak zauważyć, że w gazetach z końca miesiąca znajduje się więcej ogłoszeń o tej tematyce niż w innych. Łącznie we wskazanych gazetach umieszczono 30 anonsów.

Ogłoszenia można podzielić na dwie grupy: szczegółowe i ogólne. Do pierwszej z nich należą te, w których wskazuje się proponowaną metodę aborcji. Przykładem takiego ogłoszenia jest: GINEKOLOG A. B., 100\% bezpieczne i skuteczne, bezzabiegowe, przywracanie opóźniajacego się cyklu miesiaczkowego, różne metody, wieloletnie doświadczenie $w$ zakresie ginekologii i położnictwa, bezpłatna porada $i$ wizyta kontrolna. WARSZAWA t.XXX-XXX-XXX ${ }^{12}$. W tym ogłoszeniu lekarz proponuje aborcję farmakologiczna, czyli bezinwazyjną. Podkreślone zostało także doświadczenie

12 Ogłoszenie, w: Usługi, w: Zdrowie, w: „Oferta" Warszawska Gazeta Bezpłatnych Ogłoszeń, nr 1759 z 12.03.2012, s. 41. 
lekarza mające prawdopodobnie wzbudzić poczucie bezpieczeństwa u zainteresowanej kobiety oraz zaoferowana została bezpłatna porada i wizyta kontrolna. Innym przykładem takiego ogłoszenia może być GINEKOLOG - POŁOŻNIK M.A. Farmakologiczne przywracanie miesiaczki (wielokrotne) Petna opieka TANIO WARSZAWA t. XXX$X X X-X X X^{13}$. W tym przypadku oferuje się również aborcję farmakologiczną. Ogłoszeniodawca zaznaczył również, że wielokrotne aborcje nie są przeszkodą do wykonania kolejnej. Prawdopodobnie ważną informacją dla zainteresowanych kobiet może być podkreślenie niskiego kosztu przerwania ciąży. Drugą grupę stanowią ogłoszenia ogólne, których przykładem jest GINEKOLOG - PEŁNA POMOC TEL.XXX-XXX-XXX LUB XXX-XXX-XXX14. W tym przypadku nie podano żadnych dodatkowych informacji. Można uznać, że lekarze umieszczający takie informacje nie preferują jednej metody przerywania ciąży, ale świadczą aborcję farmakologiczna i chirurgiczną. W badanych gazetach tylko w czterech ogłoszeniach zaprezentowano świadczone usługi w sposób ogólny.

Wiele z ogłoszeń powtarzało się. Jednym z nich było GINEKOLOG - PEENA POMOC TEL. XXX-XXX-XXX LUB $X X X-X X X-X X X$, które znajdowało się we wszystkich badanych gazetach, czy ginekolog A. B. (zamieszczone wyżej), które znajdowało się w trzech gazetach. Podobnie było z ogłoszeniem GINEKOLOG, położnik, J. A. szybkie przywracanie miesiaczki, farmaceutycznie, 100\% skuteczne, opieki $24 h$, najtaniej, WARSZAWA t. XXX-XXX-XXX ${ }^{15}$. Powtarzalność ogłoszeń świadczy o ciągłości świadczenia usługi przerywania ciąży. Można również uznać, że występuje grupa lekarzy zajmujących się wykonywaniem aborcji. Niemniej należy zwrócić uwagę na ogłoszenia jednorazowe. Znaczna liczba takich ogłoszeń pokazuje, że występuje duże zainteresowanie tego typu usługami.

\footnotetext{
Tamże.

14 Ogłoszenie, w: Usługi, w: Zdrowie, w: „Oferta” Warszawska Gazeta Bezpłatnych Ogłoszeń, nr 1765 z 26.03.2012, s. 45.

15 Tamże.
} 
Ważną zmienną jest płeć lekarzy oferujących aborcję. Aż 15 ogłoszeń wskazywało, że osobą dokonującą aborcji jest kobieta, w kolejnych 7 był to mężczyzna, a w 8 nie podano płci lekarza. Nie widać różnic w przypadku opisu świadczonych usług w ogłoszeniu ze względu na płeć. Podobnie konstruowane są także ogłoszenia, w których nie określono płci lekarza. Należy jednak zwrócić uwagę, że znaczącą liczbę ogłoszeniodawców stanowią kobiety.

W miesiącach sierpień i wrzesień 2012 r. analizie poddano ogłoszenia umieszczone na stronie internetowej gazety „Oferta”. Przypadło to na dni 17.08.2012, 23.08.2012, 31.08.2012, 05.09.2012. W każdym

z nich na stronie znajdowało się wiele ogłoszeń. Pierwszego dnia w godzinach wieczornych umieszczonych było 12 ogłoszeń, kolejnego wskazanego dnia 15, następnie odpowiednio 11 i 14 ogłoszeń. Łącznie we wskazanych dniach zamieszczono 52 oferty aborcyjne.

Podobnie jak wcześniej ogłoszenia należy podzielić na dwa typy: szczegółowe i ogólne. Pierwszego rodzaju było 49 ogłoszeń, a drugiego tylko 3. Przykładem ogłoszenia pierwszego typu może być: GINEKOLOG, PRZYWRACANIE CYKLU MIESIACZKOWEGO, BEZPIECZNIE I TANIO. FARMAKOLOGICZNE I ZABIEGI. INDYWIDUALNY DOBÓR ŚRODKÓW W ZALEŻNOŚCI OD POTRZEB ORGANIZMU PACJENTA. DYSKRECJA I SKUTECZNOŚĆ GWARANTOWANA. JESTEM LEKARZEM WIEM JAK POMAGAĆ LUDZIOM. MOŻLIWOŚĆ WIZYTY DOMOWEJ ORAZ DOJAZDU DO PACJENTA. TEL. XXXXXXXXX WARSZAWA t. XXX-XXX-XXX ${ }^{16}$. W przypadku tego ogłoszenia lekarz dokładnie przekazał informacje o świadczonych usługach. Zaznaczył, że wykonuje aborcje farmakologiczne i zabiegowe, dodatkowo podkreślił bezpieczeństwo i niską cenę usługi oraz wskazał na możliwości dojazdu do pacjentki.

16 Ogłoszenie, <http://www.oferta.pl/strona_v2/gazeta_v2/ogloszenie/view/3235785>, (dostęp: 05.09.2012). 


\section{Część I}

Współczesna sytuacja demograficzna w Polsce

Podobnie jak w przypadku ogłoszeń zamieszczonych w formie papierowej gazety, najwięcej ogłoszeniodawców to kobiety. Były one autorkami 24 anonsów. Mężczyźni byli autorami 19 ogłoszeń.

W internecie również zamieszcza się ogłoszenia bez wskazania płci lekarza. W badanych dniach było ich 9 .

Na stronie internetowej gazety "Oferta" występują również ogłoszenia dla innych części Polski.

We wskazanych dniach pojawiły się także anonsy dla rejonu białostockiego, kieleckiego, lubelskiego, rzeszowskiego, katowickiego oraz radomskiego. Łącznie było 201 ogłoszeń. Najwięcej z nich (pomijając rejon warszawski) pochodzi z regionu rzeszowskiego (40), radomskiego (40) oraz kieleckiego (34), a najmniej z katowickiego (12) oraz białostockiego (3). Poniższa tabela przestawia liczbę zamieszczonych ogłoszeń, z podziałem na dni i rejony.

Tabela 3. Wykaz ogłoszeń zamieszczonych na stronie internetowej gazety "Oferta"

\begin{tabular}{|c|c|c|c|c|c|}
\hline Rejon & 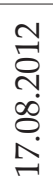 & 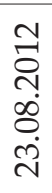 & 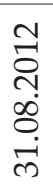 & 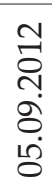 & 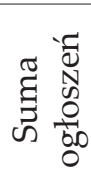 \\
\hline Warszawski & 12 & 15 & 11 & 14 & 52 \\
\hline Białostocki & 1 & 1 & 1 & 0 & 3 \\
\hline Kielecki & 6 & 9 & 2 & 17 & 34 \\
\hline Lubelski & 3 & 14 & 3 & 0 & 20 \\
\hline Rzeszowski & 7 & 11 & 9 & 13 & 40 \\
\hline Katowicki & 0 & 1 & 0 & 11 & 12 \\
\hline Radomski & 0 & 14 & 9 & 17 & 40 \\
\hline $\begin{array}{l}\text { Suma ogłoszeń } \\
\text { z danego dnia }\end{array}$ & 29 & 65 & 35 & 71 & 201 \\
\hline
\end{tabular}

Źródło: Opracowania własne.

Treść ogłoszeń zamieszczanych dla innych części kraju nie różni się od anonsów omawianych wcześniej. Podobnie, ogłoszenia charakteryzują się rozbudowaną treścią 
i większość sugerowała aborcję dokonywaną przez kobietę lekarza. Dokładniej 103 z 201 ogłoszeń wskazywało na płeć żeńska, 84 na męska, a w kolejnych 14 nie została określona płeć. Aż 197 ogłoszeń posiadało rozbudowaną treść m.in. ze wskazaniem metody przerwania ciąży, zapewnieniem opieki, czy darmowej wizyty kontrolnej. A jedynie 4 wskazywały ogólnie na świadczenie usługi aborcji. Należy jednak pamiętać, że analizie poddane zostało tylko jedno źródło, a zaprezentowane ogłoszenia pochodziły z czterech dni. Prawdopodobnie każdego dnia zamieszcza się znacznie większą liczbę takich ogłoszeń.

Jak wspomniano, informacje sugerujące świadczenie usługi przerywania ciąży ukazują się również na innych stronach internetowych. Przykładem takiej strony jest gumtree.pl, favore.pl, owi.pl, czy warszawa.oglaszamy24.pl. Na wspomnianej stronie favore.pl dnia 17.08.2012 roku widniało 18 ogłoszeń proponujących usługę przerwania ciąży. Jednym z nich było: Ginekolog-Szybkie przywracanie miesiaczki metoda farmakologiczna 100\% skuteczności do 14-16 tyg. Kontrola przez cały cykl. Badania USG 0 zł. Masz problem??? ZADZWOŃ! TEL. XXX-XXX-XXXX ${ }^{17}$. W tym przypadku lekarz proponuje aborcję aż do 16 tygodnia ciąży. Na stronie internetowej gumtee.pl zamieszczono 3 ogłoszenia typu Ginekolog 24h. - Bezbolesne Przywracanie cyklu, Petna Dyskrecja ${ }^{18}$. Z kolei pod adresem owi.pl znajdowały się 2 ogłoszenia. W obu umieszczono informacje o możliwości dokonania aborcji w późnych tyg. ciąży. W pierwszym był to 16 , a w drugim 12-14 tydzień. Na stronie warszawa.oglaszamy24.pl widniało 5 ofert nie różniących się znacznie treścią od wcześniejszych.

Na uwagę zasługuje również istniejący ranking lekarzy i miejsc świadczących usługi aborcji na stronie znanylekarz.pl. W dniu 17.08.2012 r. znajdowały się dwie

\footnotetext{
17 Ogłoszenie, <http://www.favore.pl/280815_ginekolog-przywracanie-cyklu-100-skutecznosc-warszawa-mazowieckie.html>, (dostęp: 17.08.2012).

18 Ogłoszenie, <http://warszawa.gumetree.pl/c-Firmy-Usługi-pielegnacjauroda-Ginekolog-24h-Bezbolesne-Przywracania-cyklu-Pelna-Dyskrecja-W0QQAdIdZ396209126>, (dostęp: 17.08.2012).
} 
listy. Pierwsza oceniająca lekarzy przerywających ciążę w Warszawie, oraz druga dotycząca lekarzy z całego kraju. Ranking specjalistów warszawskich liczył 6 pozycji, a ogólnopolski 21. Dodatkowo istnieje możliwość wystawienia wirtualnej oceny lekarzowi. Istnienie tego typu rankingów świadczy o tym, że kobiety poszukują lekarzy z rekomendacjami. Pokazuje to również, że kobiety decydujące się na aborcję poszukują poczucia bezpieczeństwa oraz pewności wiedzy i doświadczenia lekarza ${ }^{19}$.

\section{Przerywanie ciąży - analiza rozmów telefonicznych}

Jak przedstawiono w części „metodyka badań nt. przerywania ciąży" wykonano próbę połączenia telefonicznego z 15 ogłoszeniodawcami. Z 11 osobami podjęto rozmowę, a z 1 wymianę wiadomości sms. Jedną rozmowę przeprowadził mężczyzna, a z 3 osobami nie można było nawiązać kontaktu telefonicznego. Część z rozmówców znajdowało się w miejscach publicznych, a podczas jednej rozmowy było słychać płacz dziecka. Wśród rozmówców było 6 mężczyzn i 6 kobiet. Tylko jeden lekarz odmówił udzielenia "pomocy”, mimo, że ogłoszenie sugerowało świadczenie tego typu usług. Brzmiało ono GINEKOLOG A. M. - szybkie, bezinwazyjne przywracanie cyklu, porady na dyskretne tematy, możliwości indywidualnego dojazdu KIELCE t. $X X X-X X X-X X X^{20}$. Powodem tego mogły być przychodzące wiadomości tekstowe na telefon, z którego wykonywane było połączenia telefoniczne powodujące dźwięk podobny do nagrywanej rozmowy.

Rozmowa telefoniczna we wszystkich przypadkach pod względem technicznym wyglądała podobnie. Na po-

19 Ciąży lekarz prywatnie usuwanie Ginekolog, <http://www.znanylekarz. pl/ranking-lekarzy/ginekolog/ciazy-lekarz-prywatnie-usuwanie>, (dostęp: 17.08.2012); Ciąży usuwanie. Ranking lekarzy Warszawa, <http:// www.znanylekarz.pl/ranking-lekarzy/warszawa/ciazy-usuwanie>, (dostęp: 17.08.2012).

20 Ogłoszenie, <http://www.oferta.pl/strona_v2/gazeta_v2/ogloszenie/view/3212572> , (dostęp: 05.09.2012). 
czątku przedstawiono sytuację, w jakiej rzekomo znalazła się kobieta, a następnie w zależności od przebiegu rozmowy starano się uzyskać informacje takie jak cena zabiegu, metoda, czy możliwe skutki niepożądane. Wszystkie rozmowy trwały od kilku do kilkunastu minut. Badani lekarze podczas rozmów świadczone usługi nazywali najczęściej farmakologia, ale również podały określenia aborcja, czyszczenie, skrobanka, pozbycie się problemu, czy wywołanie miesiączki. Używanie tych określeń nie stanowiło wśród badanych problemu.

Lekarze podczas rozmów starali się uzyskać informacje nt. długość trwania ciąży. Część z badanych pytała bezpośrednio o datę ostatniej miesiączki, a innym wystarczała informacja, że jest to ok. 4-5 tydzień, na podstawie której samodzielnie obliczali poziom zaawansowania ciąży. Jeżeli miesiaczka była 5 tygodni temu, to poziom rozwoju płodu liczymy sobie nie od poczatku miesiaczki, ale od połowy cyklu. Te dwa tygodnie należałoby się cofnać wstecz, także u Pani byłby to mniej więcej trzeci tydzień poziomu rozwoju. Ze wszystkich rozmówców tylko jeden lekarz poprosił o wykonanie badania BHCG. Jest to badanie, na podstawie którego jesteśmy w stanie określić poziom rozwoju zarodka. Jest to badanie płatne, takie badanie proszę Pania wykonuje każde laboratorium przy czym jest to koszt około 50 złotych. W godzinach porannych robi sobie Pani. Pobieraja krew i się czeka na wynik z tym wynikiem by Pani do mnie zadzwoniła. Jest to badanie nie rejestrowane także jest tutaj petna dyskrecja - wyjaśnił. Jedenastu lekarzy zapytało o przebyte wcześniej ciąże, a pięciu o wiek pacjentki. Rozmówcy podkreślali, że brak wcześniejszych ciąż nie stanowi problemu do wykonania aborcji. Dodatkowo jedna osoba zapytała, czy kobieta jest pełnoletnia, jednak nastąpiło to dopiero po dłuższej rozmowie. Stwierdziła również, że sądziła, iż dzwoniąca kobieta nie ukończyła 18 roku życia. Takie podejrzenia nie stanowiły problemu w kontynuowaniu rozmowy. Inną informacja, która próbowali uzyskać lekarze, były przebyte choroby oraz uczulenia. Kilku lekarzy podchodziło do tego swobodnie, m.in. pytając ogólnie, czy pacjentka 
na „coś” choruje lub przyjmuje leki, uzyskując negatywną odpowiedź uznawali, że stan zdrowia pozwala na aborcję. Inni prowadzili dokładne wywiady, pytając, czy pacjentka chorowała lub choruje na: nadciśnienie tętnicze, serce, wątrobę, nerki, cukrzycę, problemy z krzepnięciem krwi, arytmię serca, anemię, jak również o to, czy były wcześniejsze ingerencje w szyjkę macicy oraz czy wykonywano badania cytologiczne. Lekarze, słysząc, że pacjentka nie choruje, stwierdzali, że nie ma przeciwwskazań do aborcji.

Obecnie w podziemiu aborcyjnym występują dwie metody przerywania ciąży: farmakologiczna i chirurgiczna. Wśród przeprowadzonych rozmów telefonicznych tylko dwóch lekarzy stwierdziło, że nie wykonuje zabiegów aborcyjnych. Jedną z nich była kobieta twierdząca, że oferuje jedynie farmakologię, a drugą mężczyzna, który stwierdził, że obecnie oferuje jedynie leki ze względu na ryzyko, jakie niesie ze sobą wykonywanie zabiegów w gabinecie. Lekarze podkreślali, że metoda zabiegowa jest bardziej ryzykowna od farmaceutycznej. Przy zabiegu, czyli skrobance, czyszczeniu, istnieje ryzyko zawsze, że później może być sytuacja taka w przyszłości, że nie będzie mogła Pani zajść w ciąże. Jest zawsze takie prawdopodobieństwo. Przy farmakologii nie ma. Jeśli nigdy wcześnie Pani nic takiego nie robita - powiedział jeden z lekarzy. Powiem Pani tak, kiedyś swego czasu robiono zabiegi w gabinecie to taka opcja istniata - nie?że mogło być, bład lekarza i po prostu można było tych dzieci nie mieć. Przy tej kuracji, przy tych lekach teraz w gabinecie tego nie robimy, bo ryzyko itd. A przeciwwskazań na pewno, na pewno może Pani mieć dzieci w przyszłości - potwierdził inny rozmówca. No to tu nie ma sensu jakiegokolwiek zabiegu. Bo zabieg przede wszystkim to jest tak, że potrzeba dokumentacji całej historii choroby wszystkich tak od urodzenia. Bo trzech anestezjologów musi mieć do usypiania wszystkie..., cała historię choroby, tak? Żeby Pania wybudzić. (...) Nie dość, że to jest kosztowne, po drugie farmakologiczne leki tak samo działaja jak zabieg - dodał lekarz. Rozmówcy wskazywali bardzo wysoką cenę za dokonanie aborcji metodą chirurgiczną. 
Ceny wahały się od 3,5 do 5 tys. Dodatkowo lekarze odradzali wykonania aborcji metodą inwazyjną na tak wczesnym etapie ciąży. Sugestie były jednak delikatne. Przykładem jednej z nich jest Zależy Pani na zabiegu, czy można to zrobić metoda bezinwazyjna nie rozwierając szyjki macicy? Wtedy jest dla Pani bezpieczniej.

Druga metoda jest użycie środków farmakologicznych powodujacych poronienie. Farmakologia (...) to sa tanie preparaty odpowiednio dobrane do wagi, wieku, czy byty dzieci, czy byty te porody, czy nie było. Te preparaty maja za zadanie wywołać odpowiednie skurcze macicy $i$ spowodować odklejenie się tego pęcherza płodowego łącznie z łożyskiem, prawda? To wyglada jak samoistne poronienie. Nawet jeśli jest ta ciąża $i$ dochodzi termin rozwiazania $i$ nie ma odpowiednich prawda skurczów wtedy podaje się wtaśnie preparaty naskurczowe w celu wywotania tych skurczy - wyjaśnił rozmówca. Przywrócenie całego procesu wiąze się tylko i wyłacznie na ustugach farmakologicznych. To co moge Pani tutaj zaproponować jest to forma stopniowa, zażywa Pani odpowiednią ilość farmaceutyków. W ciąu kilku godzin dochodzi do odpowiednich tutaj efektów pożądanych - objaśniła kolejna osoba. Następny lekarz przekonywał o lepszej jakości oferowanych przez niego leków, twierdząc, że różnią się od innych stężeniem substancji odpowiadających za jego działanie. Jest to opakowanie takie samo tylko przede wszystkim różni się jeden składnik mirostol. $\mathrm{Na}$ tych z Internetu i na tych z apteki ma Pani 0,02\%, 0,02 g. na jedna tabletke, a my szpitalne mamy 0,20. Także jedna tabletka szpitalna jest odnośnikiem 20 tabletek całego opakowania aptecznego - stwierdził. Część z badanych lekarzy zalecała przyjmowanie tabletek doustnie, a inni dopochwowo. Zdaniem zwolenników aplikowania leków dopochwowo, skutki występują szybciej niż w przypadku przyjmowania ich doustnie. Sa lekarze, którzy stosuja te tabletki dopochwowo. Czyli dopochwowo bierze się tam co ileś godzin. I faktycznie one skutkuja tym, że szybciej to schodzi, tak? Ale ten lek jest w przeciagu trzech miesięcy u Pani do wykrycia. Jeżeli Pani może to ryzyko jest bezsensowne w ogóle. Lepiej sobie poczekać te dwie godziny, rozpuścić je pod językiem, tak? Co dwie godzi- 
ny po dwie tabletki i mieć już problem z głowy. I powiem Pani, $\dot{z}$ gdy rano wstanie i nawet jeśli Pani trafi do szpitala, czy też na przychodnie, tak? To nie jest nikt w stanie Pani wykryć, że Pani jakakolwiek aborcję miała - wyjaśnił lekarz. Zdaniem badanych, aborcja farmakologiczna jest skuteczna na odpowiednim etapie ciąży. Minimalny jest czwarty tydzień ciąży. Górna granica do zastosowania leków zależała od lekarza, dla niektórych był do 7, czy 9, a dla innych nawet 12 tydzień. Przyjęcie leków w odpowiednim momencie jest ważne, gdyż wcześniej - zdaniem jednego rozmówcy - występuje zbyt mała liczba receptorów mogących wpłynać na nieskuteczność leków. Jeden z lekarzy stwierdził, że od 8 tyg. ciąży nie można mówić już o zarodku, a o tworzącym się płodzie. Dodał również, że jest to czas wykształcania się m.in. kończyn dziecka. W przypadku ciąży w 4-5 tygodniu zarodek może mierzyć ok. $1 \mathrm{~cm}$., a łożysko ok. 5-6 cm. Inni lekarze wskazuja że może on mieć wielkość 3-5 cm. Wizualnie jest to mała, jasnoróżowa plamka.

Aborcja farmakologiczna jest znacznie tańsza od chirurgicznej. Koszt tabletek w porównaniu do cen zabiegów stanowi atrakcyjną ofertę. Ceny tabletek wahają się w granicy od 500 do 2000 zł. Dwóch lekarzy oferowało je za 500 zł, kolejnych dwóch za 800 zł, następnie trzech za 1000 zł i dwóch za 1100 zł. Najwyższa cena wynosiła 2000 zł. Jeden z lekarzy podkreślił, że występują duże wahania cen za wykonanie aborcji. Teraz nie wiem dlaczego tak jest, że te ceny spadty, bo w zeszłym roku było 1,5 tys. Ale z roku na rok to jest co innego, tak? - powiedział.

Jak wygląda aborcja metodą farmakologiczną? Według badanych lekarzy aborcja trwa jeden dzień. Polega ona na przyjęciu kilku tabletek w odpowiednich odstępach czasowych. Większość lekarzy preferowało przyjmowanie tabletek $\mathrm{w}$ godzinach porannych. Przez kilka godzin kobieta powinna przyjmować odpowiednią ilość tabletek w ustalonych odstępach czasu. U niektórych lekarzy było to 10, a u innych 12, czy nawet 20 tabletek. W przypadku aborcji farmakologicznej działa się małymi 
stężeniami przez długi czas. Po aplikacji tych środków jest to wszystko rozpuszczone, wyptukiwane, zaczyna się krwawienie - powiedział jeden rozmówców. Podczas przyjmowania leków kobieta powinna kontrolować proces poprzez obserwację. Łożysko rozleci się na dwa, trzy $i$ jednocentymetrowe tak, że jest Pani w stanie zaobserwować. Proces ten odbywa się wtedy, kiedy najczęściej jest parcie podczas oddawania mo$c z u$ - stwierdził. Po przyjęciu tabletek powinno wystąpić u kobiety krwawienie, jednak lekarze w odpowiedziach nie byli jednogłośni. Jedni twierdzili, że ustąpi ono po 3 dniach, a inni, że może utrzymywać się nawet do kilku tyg. Jeden z lekarzy, przedstawiłając proces przyjmowania leków, powiedział: Musimy leki stosować cyklicznie, także dawkujemy je co godzina, dawkujemy je w miare delikatnie. Także od 7 dawkowanie jest do godziny 12, a tu odkleja nam się łożysko na godziny popołudniowe. Średnia statystyczna wskazuje nam godzine 14-15, tutaj nam to tożysko sie odkleja. W wyniku oderwania pojawia nam sie krwawienie - tak jak w normalniej miesiączce. Dopiero później rozczepia nam się tożysko i ono będzie cykliczne sptywało w przeciagu kilku godzin no nawet do późnych godzin wieczorowych. Nawet do godziny 20 to łożysko może spływać. Krwawienie płynne zazwyczaj nam trwa tutaj do około mniej więcej dwóch, trzech dni. Początkowo jest takie sino-bordowe, brudne, organizm się musi oczyszczać. Dopiero potem ono się zamyka to krwawienie płynne i później jest czas na regeneracje, bo po oderwaniu tożyska zostały naruszone naczynka krwionośne, które musza się zagoić, zabliźnić. Później będzie czas takich drobnych plamień. Tutaj kobiety, czy po porodach, czy po naturalnym poronieniu również maja bardzo często plamienia długotrwałe. Plamienia potrafia nam się około tygodnia przejawiać. Nie krwawienia płynne ale drobne plamienia. To jest wynikiem odkurczania ścianek macicy. Inny lekarz powiedział: Przez pierwszy dzień te krwawienie jest no takie najbardziej intensywne, najbardziej nasilone. Potem przez około 3-4 dni utrzymuje się coś bardziej na poziomie normalnego okresu miesięcznego. Tak to wyglada w przybliżeniu. Jeszcze inny lekarz stwierdził, że (...) przez dwa tygodnie, do trzech tygodni utrzymuj się plamienie takie większe, mniej- 
sze, bo organizm się z tego oczyszcza, ale nie ma tutaj potrzeby ingerencji lekarza i po około 4-6 tygodniach efekt miesiaczkowy. Prawdopodobnie proces ten wygląda nieco inaczej u każdej kobiety.

Rozmówcy przedstawiali różne podejście do aktywności fizycznej podczas brania leków. Część twierdziła, że sprzyja ona „kuracji”, a inni byli przeciwnego zdania. Jeden z lekarzy stwierdził, że powinno unikać się wysiłku fizycznego przez ok. 2 tyg., gdyż może to spowodować naruszenie ścianek szyjki macicy. Jednak, wszyscy lekarze byli zgodni, że kobieta powinna przyjmować leki, przebywając w domu. Podkreślali, że ważne jest, aby kobieta czuła swobodę, intymność, a także miała możliwość obserwacji. Najlepiej to sobie zaczać od rana i mieć wolne od pracy. Od pracy, bo to nie chodzi o zajęcia wręcz przeciwnie można nie wiem..., mycie okien, sprzątanie, ruch, goracy prysznic itd., ale chodzi o ta intymność po prostu. To też będzie dla Pani uciązliwie, jak będzie Pani pracowała chodzić do toalety i sprawdzać - dodał inny. W przypadku, gdy kobieta zaobserwuje działanie leków poprzez wydalenie łożyska i zarodka nie jest konieczne robienie dodatkowych badań. (...) Jeśli Pani zaobserwuje to nie ma potrzeby robienia USG, czy tak dalej. Chyba, że Pani nie zaobserwuje no, że to zeszło, co miało zejść to trzeba zrobić po prostu USG. Ale jeśli Pani zaobserwuje to nawet nie ma potrzeby robienia jakichkolwiek dodatkowych badań. Te leki załatwiaja sprawe od A do Z, czyli do końca wszystko. Kilku lekarzy mimo to zachęcało do wykonania, chociażby testu ciążowego, a jeszcze inni mają w swojej ofercie wizytę kontrolną.

Podczas przyjmowania leków wywołujących poronienie mogą występować skutki uboczne, które można podzielić na krótkoterminowe (występujące podczas przyjmowania leków) i długoterminowe (występujące w późniejszym terminie). W przypadku tych drugich występuje rozbieżność w opiniach lekarzy. Przykładam jest utrzymujące się krwawienie, w przypadku którego - jak wcześniej wspomniano - lekarze podają rozbieżne terminy oraz wpływ na przyszłe ciąże. Jeden z lekarzy stwier- 
dził, że po przyjęciu leków kobiety szybciej zachodzą w ciąże. (...) Na pewno może Pani mieć dzieci w przyszłości. Niech się Pani nie obawia po tej kuracji trzeba uważać, bo się szybko zachodzi w ciązę. Ja mam dużo takich przypadków, że po tej kuracji no z powrotem niestety ale sa w ciaży. Inna rozmówczyni była przeciwnego zdania, gdyż powiedziała: (...) Przez pót roku należy sobie darować jeżeli chodzi o dzidziusia. Następny dodał: Skutków ubocznych nie powinno być wie Pani.(..) Jest tak, że po prostu takie zwyżki zostaja i wtedy trzeba wyłożyskować, ale wtedy może Pani np. położyć się na oddziat i nikt nie rozpozna, że Pani coś brała. Znacznie więcej lekarze mówili na temat skutków krótkoterminowych. Zdaniem jednego badanego, leki farmakologiczne działają głównie na płód, a nie na kobietę. Wśród skutków lekarze wymieniają biegunkę, wymioty, podwyższoną temperaturę ciała w przedziale 37-38 stopni oraz występujące skurcze. Reakcja w postaci drobnych skurczy - bo nigdy nie da sie tego uniknać - tutaj macica będzie generowała drobne skurcze, aż doprowadza do wydalenia tego płodu. Będa drobne bóle skurczowe, będzie wzrost temperatury w przedziale 37-38 stopni, może być lekka biegunka. Tego nie jesteśmy w stanie uniknać, bo to sa rzeczy zwiazane z tym całym procesem. Tutaj stosujac takie leki my prowokujemy wydalenie płodu. Powodujemy poronienie - opisał jeden z rozmówców. Dokonanie aborcji metodą farmakologiczną niewiele różni się od naturalnego poronienia. Badani wskazuja że przebieg jest taki sam, a jedyną różnicą jest to, że to leki prowokują rozpoczęcie procesu. Jak już wcześniej wspomniano, po przyjęciu leków rozpoczyna się krwawienie. Jeden z lekarzy powiedział, że w niektórych przypadkach jest ono zbyt intensywne i wymaga konsultacji lekarskiej. Bo sa przypadki - 1\% - że jest zbyt silne krwawienie, wtedy skieruje Pania na oddziat do szpitala. Wtedy musi się Pani udać tam, w celu podania leków przeciwzakrzepowych, a on jest w kroplówce. Także to tak wyglada, ale to jest $1 \%$ także proszę się nie martwić. Rzadko kiedy się to zdarza - powiedział.

Jeden z rozmówców dodał, że bywają przypadki, gdy aborcja farmakologiczna nie powiedzie się. Wówczas ko- 
nieczne jest powtórzenie kuracji. (...) Zdarza się czasami sytuacja taka, że odklei się ten pęcherzyk natomiast zostanie część tożyska na macicy. Wtedy po około 6 dniach po zastosowaniu pierwszych, w takich przypadkach jeśli by zostało prawda pokaże się te krwawienie i wyjdzie ten pęcherz natomiast zostanie część łożyska, łożysko prawda. Zatrzymuje się niestety okres $i$ trzeba powtórzyć tę serię - powiedział lekarz. Dodał również, że w takich przypadkach drugą serię tabletek przekazuję bezpłatnie. Kuracja może również być nieudana jeżeli, kobieta nie przyjmie wszystkich przekazanych leków. Trzeba wybrać wszystkie leki do samego końca z tego względu żeby łożysko zeszło, żeby Pani później po 2 tygodniach nie trafiła do szpitala na czyszczenie. Lekarze zgodnie podkreślali, że kobieta podczas przyjmowania leków nie może nic jeść, gdyż nawet drobny posiłek może wpłynacć negatywnie na przebieg kuracji.

Badani twierdzili, że podczas spotkania, na którym przekazują leki, dokładnie informują pacjentkę o przebiegu kuracji oraz możliwych skutkach. Niektórzy oferują dodatkowo kartkę ze wskazówkami, a jeden badany zaoferował samą wysyłkę leków. (...) Sama rozmowa z takimi kobietami trwa mniej więcej około pół godziny, nawet do godziny., aby przekazać odpowiedni zasób informacji, żeby Pani wiedziała jak ten lek stosować i co po kolei tutaj będzie się odbywało, jak mamy reagować na jakiekolwiek efekty, czy na temperature, czy na biegunke, czy na jakieś inne rzeczy, które mogłyby Pania zaskakiwać". Podczas przyjmowania przez kobietę leków badani chcą być z pacjentką w stałym kontakcie. Nie jest to kontakt bezpośredni, a jedynie telefoniczny, albo smsowy. (...) W dniu stosowania jesteśmy cały czas w kontakcie telefonicznym. Jakiekolwiek krwawienia, czy plamienia, czy skurcze musi Pani do mnie dzwonić i informować mnie żeby wiedziat co się z organizmem dzieje" - powiedział rozmówca. Jeden z lekarzy dodał, że w przypadku nagłych sytuacji dojeżdża do domu pacjentki. Podał również przykład z własnego doświadczenia, kiedy przekazał leki kobiecie, która twierdziła, że jest w 6 tygodniu ciąży, a w rzeczywistości była w 24 tygodniu ciąży. Sytuacja ta pokazuje, że lekarze 
nie prowadzą dobrych wywiadów z potencjalnymi pacjentkami i swobodnie przekazują leki poronne.

Podczas rozmów wielu z lekarzy starało się przekonać potencjalną pacjentkę o jakości świadczonych usług. Starali się to robić, podkreślając wieloletnie doświadczenie lub oferując dodatkowe usługi, np. późniejszą kontrolę, czy stały kontakt podczas przyjmowania leków z lekarzem. Jeden z badanych powiedział, że od 12 lat świadczy usługę aborcji. Dodał także, że od tego czasu dostępny jest pod stałym numerem telefonu przeznaczonym do kontaktu z kobietami decydującymi się na aborcję. Warto również podkreślić, że podczas rozmowy padały określenia świadczące o dużym zainteresowaniu tego typu usługą. Jeden z lekarzy stwierdził, że ma dużo przypadków, że kobiety po aborcji wracają wykonać kolejna, a inny, że wiele $\mathrm{z}$ jego pacjentek ma obawy co do bezpieczeństwa kuracji lub zabiegu. Jednak używanie przez lekarzy słów „dużo”, czy „wiele” pacjentek świadczy o tym, że występuje zainteresowanie aborcją w podziemiu aborcyjnym.

Reasumując, należy zaznaczyć, że żaden z lekarzy nie naciskał na wykonanie aborcji. Podkreślali jednak, aby zastanowić się i "spokojnie” podjąć decyzję. Jak się Pani zdecyduje i będzie Pani pewna swojej decyzji to prosze w takim razie o telefon - powiedział jeden z lekarzy. U wszystkich badanych leki można było odebrać już nawet kolejnego dnia po rozmowie.

\section{Podsumowanie wyników badań}

Przeprowadzone badania wykazały, że w Polsce istnieje łatwy dostęp do ogłoszeń sugerujących świadczenie usługi przerywania ciąży. Jak wynika z przeprowadzonej analizy, każdego dnia w prasie i na stornach internetowych ukazuje się wiele ogłoszeń aborcyjnych. Większość anonsów była przedstawiona szczegółowo, ale w taki sposób, aby nie ukazywać, że oferuje się wykonanie nielegalnego czynu. 
W ogłoszeniach zaznacza się np. „pełną pomoc kobietom”, czy „przywracanie cyklu”. Znaczna liczba anonsów zawierała informacje m.in. o metodzie aborcji, kontroli lekarskiej, czy dodatkowych usługach takich jak późniejsza darmowa wizyta kontrolna.

W podziemiu aborcyjnym lekarze przerywają ciążę za pomocą dwóch metod: farmakologicznej i chirurgicznej. Pierwsza z nich była preferowana przez badanych we wczesnym etapie ciąży. Niemniej nie zaprzeczają oni możliwości wykonania zabiegu. Badani podkreślali, że aborcja za pomocą leków jest bezpieczniejsza dla kobiety, a wśród skutków ubocznych może ich zdaniem wystąpić biegunka, gorączka, czy ból związany ze skurczami. Rozmówcy twierdzili, że wykonanie aborcji farmakologicznej trwa jeden dzień i polega na przyjęciu odpowiedniej liczby farmaceutyków.

Badani proponowali rozbieżne ceny za leki aborcyjne. Wahały się one od 500 do 2000 zł. Znacznie więcej kosztuje aborcja chirurgiczna, gdyż kilka tys. zł. Podczas rozmowy telefonicznej lekarze byli bardzo życzliwi, chętnie odpowiadali na zadawane pytania oraz starali się dokładnie przedstawić świadczone usługi.

Reasumując, należy stwierdzić, że dotarcie do ogłoszeń sugerujących świadczenie usług aborcyjnych, nawiązanie kontaktu z osobą sprzedającą leki do aborcji farmakologicznej, czy umówienie się na zabieg nie stanowi problemu. Znaczna liczba lekarzy zajmujących się tego typu usługami świadczy o dużym zainteresowaniu kobiet przerywaniem ciąży w podziemiu aborcyjnym.

W świetle wyników badań można wysunąć wniosek, że ruchy pro-life większą uwagę zwracają nie na skuteczność ustawy z 7 stycznia 1993 r., ale na jej utrzymanie. W tym kontekście jeszcze gorzej wypadają skrajnie prawicowi politycy, którzy co jakiś czas podejmują spektakularne inicjatywy na temat konieczności jej zaostrzenia $\mathrm{w}$ sensie formalnym, nie robiąc natomiast nic na rzecz podniesienia jej praktycznej skuteczności. 


\section{Abortion: the legal status versus the actual state}

\section{Summary:}

The article describes the actual condition of abortion underground in Poland. It mentions legal regulations regarding abortion and also includes a study of the accessibility of illegal pregnancy interruption.

The main idea behind the research was to measure the actual effectiveness of legal regulations regarding abortion through the study of how difficult it actually is to perform the previously mentioned procedure. The study was based upon the analysis of abortion-related advertisements posted in newspapers by the name of "Oferta", Warszawska Gazeta Bezpłatnych Ogłoszeń or internet pages, i.e. gumtree.pl or owi.pl. Some of the aforementioned advertisements were afterwards validated by means of a phone conversation. The total number of 12 service providers were contacted and each of them was asked about the following aspects: the price, the possible date, possible undesired side effects and details of the procedure.

The research proved that the abortion procedure is fairly accessible through a number of doctors providing such services. All the supported data could be concluded with the following statement -current Polish law regulations regarding abortion are very often disregarded. 



\title{
Część II
}

\author{
OPINIE \\ RELACJE \\ SPRAWOZDANIA \\ ŚWIADECTWA
}





\section{Teresa Kapela}

Wiceprezes Związku Dużych Rodzin „Trzy Plus”

\section{Rodziny wielodzietne w Polsce}

\section{Zamiast wstępu}

Niniejsze przemyślenia nie są refleksją naukową ale spojrzeniem obserwatora życia społecznego i osoby mocno zaangażowanej w pracę stowarzyszeń rodzinnych, a również $\mathrm{w}$ wymianę międzynarodową - europejską dotyczącą doświadczeń w zakresie polityki rodzinnej. Podjęto i omówiono w tekście następujące kwestie:

- założenia programowe stowarzyszeń rodzinnych funkcjonujących w Europie;

- stereotypy dotyczące rodziny wielodzietnej w Polsce;

- terminologia i pojęcia towarzyszące planowaniu rodziny;

- odpowiedź na pytanie: kim są rodziny wielodzietne?;

- refleksje nad kilkoma stwierdzeniami wyniesionymi z konferencji europejskich.

\section{Przesłanki ideowe}

XIX i XX wiek przyniósł ogromne zmiany w funkcjonowaniu społeczeństw i funkcjonowaniu rynków pracy. Ponad sto lat temu zaczęto zauważać dysproporcję w sytuacji pracownika utrzymującego tylko siebie i pracownika mającego ma utrzymaniu żonę i dzieci. W ten sposób zaczęły powstawać zasiłki na dzieci, początkowo w firmach prywatnych, po drugiej wojnie światowej stały się powszechnym narzędziem przysługującym wszystkim rodzicom wychowującym dzieci. W większości krajów europejskich są jednym z mechanizmów wyrównujących sytuację osób inwestujących w dzieci i tych, którzy takiej 
inwestycji nie podejmują. Taka sytuacja miała miejsce również w Polsce do momentu transformacji.

W 1945 r we Francji została wprowadzona Karta Dużej Rodziny, Święto Matki i odznaczenia dla rodzin. W Polsce dość dobrze funkcjonuje Dzień Matki, choć można by się zastanawiać, czy nie jest zdominowany przez Dzień Dziecka - nieistniejący zresztą we Francji. Nasze stowarzyszenie mocno się zaangażowało w proces wprowadzenia Karty Dużych Rodzin i podkreślenia roli rodziców. W dniu 15 maja 2012 r. po raz pierwszy zostały odznaczone rodziny za ich trud i osiągnięcia przez Parę Prezydencką. W Europie przywiązuje się również dużą wagę do stowarzyszeń rodzinnych. Stowarzyszenia Rodzin Katolickich mają za sobą tradycję 100 lat działalności - wyrosły one na fali ustaw laicyzacyjnych, w obronie praw rodziny. Stowarzyszenia rodzinne są w Europie najlepiej zorganizowaną strukturą stowarzyszeniowa, z funkcją konsultacyjna, doradczą i opiniotwórczą. W zeszłym roku przeprowadziłam przegląd federacji stowarzyszeń rodzinnych podczas w konferencji w Gdańsku, opublikowany przez KAI w grudniu 2011 r. W Europie funkcjonuje szereg federacji i stowarzyszeń rodzinnych, a wśród nich najbardziej znane, to: COFACE, FAFCE, ELFAC, FEFAF, WFO - sekcja europejska, MMM - sekcja europejska. Paradoksem jest fakt, iż docierają do naszego stowarzyszenia konsultacje w sprawach dotyczących rodzin ze szczebla UE, natomiast nie ma takiej praktyki na szczeblu krajowym. Doprowadziliśmy w Polsce do sytuacji tak mocnego rozdrobnienia stowarzyszeń, że nie wiadomo, jak się w tym gąszczu odnaleźć. Jednocześnie dominuje brak elementarnej wiary w możliwość i skuteczność działań podejmowanych oddolnie.

\section{Rodziny wielodzietne}

W 2005 r powstała w Europie federacja Stowarzyszeń Rodzin Wielodzietnych ze znamiennym mottem "Rodziny wielodzietne nie są problemem, są rozwiązaniem”. 
Wydaje się, że rodziny wielodzietne w obliczu kryzysu demograficznego są faktycznie rozwiązaniem, ale mają też specyficzne potrzeby. Są najmocniej obciążone bardzo istotnym obecnie podatkiem - podatkiem VAT. Ulga podatkowa wprowadzona w Polsce jest jedynie zwrotem podatku zapłaconego od konsumpcji dziecka na poziomie 400 zł miesięcznie. Oblicza się, że rodzice nawet kosztem swoich potrzeb wydają przynajmniej 500 zł miesięcznie na każde dziecko. W kwestii korzystania ze środków transportu, zwłaszcza samochodów, sytuacja w Polsce także nie jest zbyt korzystna. Np. w Niemczech dopuszcza się przewożenie więcej niż 9 osób, kiedy są to własne dzieci, nawet jeśli z przepisów dotyczących prawa jazdy wynikają inne ograniczenia. Poza tym, w Polsce szereg banków żąda zgłoszenia kolejnych dzieci w przypadku zaciągniętego kredytu mieszkaniowego, a wynikający z tego brak zdolności kredytowej może postawić rodziców wobec wypowiedzenia warunków kredytu. Nie rozwiązujemy problemów stojących przed potencjalnymi rodzicami, a jedynie je pogłębiamy i dotyczy to nie tylko rodzin wielodzietnych, ale wszystkich rodzin żyjących w Polsce. Może warto się pochylić nad tymi zagadnieniami i sprawdzić, skąd się one biorą.

\section{Stereotyp rodziny wielodzietnej w Polsce}

$\mathrm{Na}$ początku podejmijmy kwestię rodzin wielodzietnych w ogóle. We Francji w odniesieniu do tego typu rodzin natychmiast pada określenie katolickie lub arystokratyczne, ostatnio zwykło się dodawać także emigranckie. W Polsce, niestety, najczęstszym skojarzeniem jest patologia. Jak to się dzieje? Podobny sposób ujmowania tej tematyki powtarza się na wykładach uniwersyteckich z różnych dziedzin. W pomocy społecznej także dominuje taki negatywny obraz, a z kolei ciekawą sprawą jest, iż badania prasy z ostatnich lat mówią raczej o pozytywnym obrazie, ukazywaniu wspaniałych rodzin wielodzietnych, tak z przeszłości, jak i współcześnie funkcjonujących. 
Chciałabym w tym kontekście wskazać na kilka czynników wpływających na tworzenie opinii. Demografowie europejscy z lat 1960-1980 zakładali, że dzieci rodzą się nie w tych środowiskach, w których oni by tego oczekiwali, że klasa średnia ogranicza się jedynie do dwójki dzieci. Lata 1990-2000 przyniosły lęk wobec wyżu demograficznego, obliczono między innymi, że 40\% młodzieży wchodzącej na europejski rynek pracy to Polacy. Decydenci zrezygnowali z polityki społecznej na rzecz doraźnej pomoc społecznej. Informacja o rodzinach zaczęła spływać jedynie za pośrednictwem pomocy społecznej. A rodziny nie chcą być wrzucane do pomocy społecznej i korzystają z niej jedynie w najdrastyczniejszych sytuacjach. Nota bene, bardzo rzadko mogą liczyć na faktyczną pomoc, będąc pełną rodziną. Zapisy o obowiązku alimentacyjnym są często wykorzystywane, aby tej pomocy nie udzielić - przenosząc obowiązek pomocy na rodziców oraz rodzeństwo. $\mathrm{W}$ związku z tym, jeżeli obraz rodzin wielodzietnych budowany jest jedynie przez pryzmat opieki społecznej, odbiega on całkowicie od obiektywnego obrazu. Niestety, nie dysponujemy innymi danymi, brak również rzetelnych badań dotyczących kondycji polskich rodzin. Te, które trafiają do nas $\mathrm{z}$ areny międzynarodowej OECD i UNESCO, przedstawiające obraz polskich dzieci jako najuboższych w Europie, żyjących w najgorszych warunkach mieszkaniowych, budzą autentyczne zdumienie. Wciąż brak odpowiedzi na pytanie postawione w $2010 \mathrm{r}$. w Sejmie RP przez sprawozdawcę OECD: Polsko, co z tym zrobisz?

\section{Dane ewidencyjne}

Dane ewidencyjne ludności są zbudowane wokół roczników podlegających edukacji. Pytanie o liczbę rodzin wielodzietnych pozostaje bez odpowiedzi - wymaga ręcznego przeglądania kartotek. W dowodach osobistych też nie mamy już dzieci, nie ma już rodzinnych książeczek ubezpieczeniowych. Jedynym dokumentem pozostaje akt 
urodzenia dziecka. To przedziwna sytuacja, która dziwi Europejczyków, podobnie jak brak uwzględnienia dzieci w podatkach osobistych. Wszystkie liberalne podręczniki mówią o podatku płaconym przez rodzinę, a nie osobę indywidualną.

\section{Planowanie rodziny}

Na te wszystkie zmiany nakłada się mocno ugruntowane nauczanie na temat planowania rodziny. To pojęcie sprawia coraz większe trudności. Oczywiście, w okresie, w którym dotyczyło bezpośrednio mojej osoby, wydawało mi się bardzo istotne i ważne i w miarę upływu czasu prowokuje postawienie bardzo konkretnych pytań. Pierwsze: czy osoba biedna ma prawo mieć dzieci? Drugie: kiedy postrzegamy kogoś za biednego? Trzecie: czy jesteśmy w stanie przewidzieć, jakie będą nasze losy przez najbliższe 20-30 lat, czy zawsze będziemy w stanie zabezpieczyć wszystkie potrzeby naszych dzieci? Czwarte: czy nauczanie o planowaniu rodziny nie jest zrzuceniem odpowiedzialności i szukaniem łatwych rozwiązań? I w końcu trzeba zapytać: jak wygląda nasza odpowiedzialność jako społeczeństwa za przyszłość? Rodzice inwestują w dzieci, a społeczeństwo przerzuca na nasze dzieci odpowiedzialność za system emerytalny, opiekę nad tymi, którzy nie zdecydowali się na dzieci, budowanie przyszłości, której sami nie chcieli.

\section{Kim są rodziny wielodzietne w Polsce}

Pozostaje pytanie, które sobie stawiam, ale chętnie postawiłabym je także i państwu: kim są właściwie rodziny wielodzietne w Polsce? Nie ma praktycznie żadnych badań na ten temat. Jedyne szersze badanie, jakie przeprowadzono, miało miejsce ponad 10 lat temu w środowisku poznańskim, z inicjatywy "Głosu dla życia” i wieloletniego radnego Pawła Wosickiego. Przeprowadzone zostało na bazie ksiąg parafialnych i z tego powodu jest kwestio- 
nowane przez badaczy. W wyniku badania określono, że liczba rodzin wielodzietnych z trudnościami jest zbliżona do wszystkich innych grup społecznych i wynosi około $10 \%$. Podobne wyniki dały badania węgierskie, które były bardziej dokładne i szczegółowe. Na uwagę zasługują badania KUL-u w ramach publikacji Skazani na wykluczenie, gdzie co prawda przebadano tylko 128 osób z rodzin wielodzietnych, ale tylko $8 \% \mathrm{z}$ nich było na poziomie wykształcenia podstawowego, a prognozy wskazywały, że 70\% osiągnie wykształcenie wyższe. Podobne wyniki otrzymano, badając młodzież z rodzin skupionych w Bielańskim Stowarzyszeniu Rodzin Wielodzietnych. Wydaje się, że rodziny wielodzietne są mocno skoncentrowane na „daniu w posagu” wykształcenia swoim dzieciom, nie mogąc im zapewnić innych dóbr, zwłaszcza materialnych, które zużywane są na bieżąco.

Ciekawym fenomenem wśród rodzin wielodzietnych są rodziny tzw. muzykujące,. Bardzo cenną dla mnie chwilą było zorganizowanie sceny rodzin wielodzietnych na zeszłorocznym święcie muzyki w dniu 21 czerwca. W koncercie wzięła udział rodzina Państwa Jarząbków (11-dzietna rodzina z Podhala - na różnych etapach kształcenia muzycznego), gdzie rodzeństwo pierwszy raz zagrało razem jako jeden zespół muzyczny. Kolejnym zespołem była „Kapela Dzieci Naszych”, muzykująca rodzina z Ełku. Poza tym, przecież wszyscy znamy inne muzykujące rodziny wielodzietne, takie jak rodziny Pospieszalskich, Steczkowskich, Malejonków czy Brodów.

\section{Praca $w$ domu}

Myślę, że koniecznie trzeba jeszcze powiedzieć o jednym fenomenie, a mianowicie wykluczeniu z pojęcia praca wszystkich czynności domowych. Oburzamy się, gdy słyszymy, że niektórzy domagają się pensji dla gospodyń domowych, matek ciężko pracujących w domu, uznając, że przecież to musi być z miłości, z ofiarności. Tak, ale biorąc pod uwagę, że te czynności muszą mieć miejsce, 
a zastąpienie ich usługami, powszechną gastronomią i pracownikami zawodowymi, to wymierny, wielki koszt, dlaczego nie docenić tej ciężkiej pracy? Ponadto, wprowadzenie usług bardzo ogranicza relacje rodzinne, które są wzorem i podstawą wszelkich innych relacji. W dobie obecnego kryzysu w Europie ma miejsce wielki powrót do dowartościowania rodziny. Nikt nie wątpi, że ona spełnia najlepiej i najtaniej wszystkie funkcje, jakie się przypisuje rolom społecznym. U nas obserwujemy coś przeciwnego. Tylko 8\% rodziców wie, jak wychowywać swoje dzieci deklaruje Rzecznik Praw Dziecka na bazie badań przeprowadzanych przez środowiska mające kontakt z tymi 10\% tzw. rodzin $\mathrm{z}$ trudnościami. I takie wzorce rzutują na to, w jaki sposób podejmuje się decyzje o kampaniach społecznych, wydawanych środkach z budżetu państwa. W konkursach ogłaszanych przez Ministerstwo Pracy i Polityki Społecznej nie ma żadnych adresowanych do zwykłej rodziny. Program „Rodzina w Warszawie” jest nastawiony tylko na poradnictwo, żadnych innych celów nie dostrzega i nie proponuje. Sami tworzymy świat deprecjonujący zajęcia domowe, nawet w potocznym określaniu matki jako kury domowej, a jej pracy jako jałowego siedzenia w domu, więc kto chciałby się identyfikować z tak opisywanymi zajęciami? Nie zetknęłam się nigdzie z takimi sformułowaniami, jak również żadne państwo nie pozwoliło sobie na ustawę o przemocy w rodzinie, $\mathrm{w}$ pewien sposób identyfikującą rodzinę $\mathrm{z}$ przemocą i wręcz zakładająca, w oparciu o bardzo nikłe badania, iż w 50\% rodzin dochodzi do przemocy. Polska jest tu ewenementem.

\section{Przyszłość rodzin}

W debacie przedstawicieli Unii Europejskiej zajmujących się rodziną pod hasłem "Przyszłość rodzin”, w Brukseli w październiku 2011 roku, padły dwa dla mnie kluczowe zdania: Dzieci obecnie posiadają ci, którym to przynosi radość, oraz dzieci są najważniejszym 
znakiem nadziei i pewności. I myślę, że w oparciu o te dwa stwierdzenia można budować przesłanie Kościoła na obecne czasy.

Choć jestem również pod dużym wrażeniem homilii kardynała Andre Vingt Trois w Mediolanie wypowiedzianych podczas Kongresu Rodzin. Jest to analiza sytuacji współczesnych rodzin, które muszą w trudzie budować od podstaw swoje osobiste, rodzinne szczęście, pozbawione wszelkich wzorców i wszelkiego zaplecza, jednocześnie mając poczucie, że ma to wpływ na całe społeczeństwo.

\section{Rodzina i stowarzyszenia rodzinne w Unii Europej- skiej}

Słowo rodzina nie pojawiło się do tej pory w żadnym z traktatów: Rzym, Maastricht, Amsterdam, Nicea - pada jedynie w tekstach Parlamentu Europejskiego. Karta Praw Podstawowych jest jedynym tekstem przywołującym rodzinę i brzmi on: Ochrona rodziny jest zapewniona na gruncie prawnym, ekonomicznym i społecznym. W prezydencjach narodowych kolejne kraje podejmują inicjatywy w zakresie polityki rodzinnej. W 2007 prezydencja niemiecka powołała Przymierze dla Rodziny, gdzie indziej tłumaczone jako Europejskie Porozumienie na Rzecz Rodzin. Przymierze to miało za zadanie stworzyć stałą formę wymiany dobrych rozwiązań sprzyjających rodzinie. Jedną z formuł jest stworzenie strony internetowej Europe Alliance for Family, zbierającej dane i rozwiązania funkcjonujące w poszczególnych krajach, zmiany w zakresie prawa, statystyki, informacje o konferencjach, badaniach itd. Inną z formuł są okresowe spotkania ministrów do spraw rodzin. Wiele krajów ma bowiem osobne ministerstwa rodziny. Niektóre przekazują te zagadnienia Ministerstwom Pracy i Spraw Socjalnych, co jest również przypadkiem Polski. Każdy kraj deleguje po trzech ekspertów ds. rodziny. Prezydencja czeska zwróciła uwagę, że nasze kraje pamiętają czasy, gdy 30\% dzieci było w żłobkach, 
a $90 \%$ w przedszkolach i nie chcą do tych czasów powracać. Zauważono, że jest to możliwe do zrealizowania jedynie przy przymusie finansowym, to znaczy z wycofaniem środków finansowych dla osób wybierających sprawowanie osobistej opieki nad dziećmi. Prezydencja belgijska zorganizowała konferencję „Rodziny Europy”, postulując ogłoszenie roku 2014 rokiem rodziny. Bardzo zapadło mi w serce przemówienie przewodniczącego Gezizbondu, czyli flamandzkiego stowarzyszenia rodzin, Rogera Pauly, w którym powiedział, że zajmujemy się tylko połową istotnych problemów: finansami, konsumpcja; prawdziwa katastrofa dotyka drugiej połowy - relacji, poczucia sensu istnienia. Kryzys w tej dziedzinie popycha ku depresjom, narkomanii, wyobcowaniu. Prezydencja węgierska podjęła zagadnienia dotyczące tej drugiej połowy, $\mathrm{w}$ powiązaniu $\mathrm{z}$ kwestiami demograficznymi. Tydzień Rodziny zgromadził naukowców, ministrów, a też bardzo licznie stowarzyszenia rodzinne.

Ciekawe jest prześledzenie protokołów z posiedzeń ministrów ds. rodziny. Polska ogranicza się do jednego tematu: godzenie ról zawodowych i rodzinnych. Okazuje się, że inne kraje mają dużo szerszą inwencję w tych sprawach. Są to kwestie bezrobocia młodzieży, coraz późniejszego usamodzielniania się, trudności napotykanych w zdobyciu odrębnego mieszkania, co ma wpływ na zakładanie rodzin. Tym tematom towarzyszą konkretne rozwiązania. W Hiszpanii był referowany program usamodzielniania się mieszkaniowego, wspomagania w robieniu prawa jazdy jako czynnika sprzyjającego zatrudnieniu.

Ostatnią inicjatywą i projektem UE było stworzenie programu „Family Platform”. Był to projekt badawczy zbierający istniejące badania dotyczące rodzin. Do uczestniczenia w tym projekcie zaproszone zostały wszystkie stowarzyszenia rodzinne. I mimo obaw i niepewności niewątpliwie był on przestrzenią otwartego dialogu i wymiany opinii. Jednym z ciekawych, prezentowanych w ramach „Family Platform”, materiałów był raport 
Światowego Ruchu Matek MMM. Ukazał on wybory matek w zakresie godzenia pracy zawodowej i obowiązków rodzinnych. Jedynie 11\% kobiet chce kontynuować pracę zawodową po urodzeniu dziecka. $25 \%$ chciałoby w pełni poświęcić się rodzinie, pozostałe kobiety pragnęłyby godzić bezkonfliktowo pracę i dom, w pełni oddając się pracy zawodowej dopiero po osiągnięciu przez dziecko pełnoletności. Trzeba podkreślić, ze europejski wskaźnik zatrudnienia kobiet mających dzieci do lat trzech waha się wokół $30 \%$, w sytuacji, gdy w Polsce przewyższa średnią zatrudnienia. Badania te korelują z obliczeniami prof. Adama Kurzynowskiego. W latach 80., po wprowadzeniu płatnego urlopu wychowawczego, tylko $8 \%$ kobiet nie skorzystało z niego. Podobnie w Finlandii, wprowadzenie prawa do płatnego urlopu wychowawczego w 2003 r. uchroniło kraj od kryzysu.

Komisja Europejska razem z Przymierzem dla Rodziny, powstałym w czasie prezydencji niemieckiej w UE, zorganizowała 12 października 2011 roku seminarium „Przyszłość rodzin”. Seminarium gromadziło w Brukseli 127 uczestników i prelegentów z różnych krajów. Byli wśród nich członkowie rządów, uniwersytetów, stowarzyszeń, federacji, instytutów naukowych oraz członkowie Komisji Europejskiej. Myślę, że jest to ciekawa forma wspólnego szukania dobrych rozwiązań dla przyszłości rodziny i rozwiązywania problemów, z którymi wszyscy się zderzamy. W ostatnich latach, w związku z kryzysem demograficznym, pojawia się cała gama tematyki pod hasłem „care” - opieka. Chodzi o ułatwianie opieki sprawowanej w domu, jako rozwiązania najlepszego i najtańszego, ale też ze zwróceniem uwagi na możliwości odpoczynku dla osoby opiekującej się. Bardzo ciekawy referat przedstawiła Holenderka zaprzeczająca schematowi, mówiącemu, iż osoby starsze są ciężarem dla młodszego pokolenia. Jest wręcz przeciwnie - pomoc starszych idzie od pokolenia emerytów do pokolenia dorosłych dzieci, łącznie z pomocą finansową. Natomiast potrzeba opieki pojawia się późno i rzadko dotyka sfery finansowej. 


\section{Przykłady skutecznych działań}

W dniu 1 października 2010 roku FAFCE zwróciło się z apelem do uczestników obrad plenarnych Rady Europy $\mathrm{w}$ sprawie wolności sumienia $\mathrm{w}$ wykonywaniu zawodu lekarskiego. Wcześniej opracowany i przedstawiony do zatwierdzenia raport proponował poważne ograniczenia w zakresie klauzuli sumienia w związku z ochroną życia. Głosowanie poprzedzone zostało dużą akcją informacyjną i konferencją zorganizowaną przez FAFCE. Wolność sumienia została obroniona, proponowany raport został zmieniony, zapewniając większy zakres wolności sumienia niż dotąd. Trzeba przyznać, że duży był tu udział posłów polskich w większości głosujących przeciw tej dramatycznej propozycji odchodzącej od tysiącletniej tradycji.

Innym przykładem jest ostania akcja AFC (francuskiego Stowarzyszenia Rodzin Katolickich). Zwróciło się ono do prezydenta Sarkozy'ego z petycją o wycofanie pojęcia "gender" z podręczników szkolnych. Argumentowano, że jest to pojęcie ideologiczne, za mało udowodnione i przedwcześnie podawane do wierzenia. Sarkozy przychylił się do opinii stowarzyszenia, wyrażając wdzięczność za zwrócenie uwagi na to zagadnienie.

Stowarzyszenia Rodzin Katolickich uważaja, że sprawy rodziny nie są w UE podejmowane w wymiarze, jakiego by oczekiwały. Ideałem byłoby, aby sprawy rodziny i jej potrzeb stanęły w centrum spraw podejmowanych przez Unię. Potrzebna byłaby również definicja rodziny, która mogłaby być zaakceptowana przez środowiska katolickie.

\section{Przyszłość polityki rodzinnej w Unii Europejskiej}

Sytuacja demograficzna i kryzys gospodarczy przyczynia się do szerszego szukania odpowiedzi w rozwiązaniach wzmacniających rodziny. Rodzina jest postrzegana jako najskuteczniejszy czynnik zabezpieczenia 
społecznego. Czy musimy podejmować kwestię definicji rodziny? Bardzo ważny wydaje się w tym względzie wyrok Trybunału Praw Człowieka w Strasburgu w sprawie komórek do sztucznego zapłodnienia. Chroni on naturalną potrzebę człowieka, aby wiedzieć, kto jest jego matką i ojcem. Jak ważna jest to sprawa, ukazują nam poszukiwania tych osób, którym tej wiedzy zabrakło. I dla mnie jest to ważną przesłanką do definicji rodziny. Wydaje się, że jest nieodzowny dialog miedzy rodzinami i politykami realizującymi zadania polityki rodzinnej. Skuteczna polityka rodzinna jest w krajach, gdzie rodziny biora na serio możliwość artykułowania swojego zdania. I tu muszę powiedzieć, że jestem pod wrażeniem umiejętności słuchania i chęci wzajemnego zrozumienia, pomimo barier językowych, kulturowych i różnic w sytuacjach prawnych i strukturalnych poszczególnych krajów. 


\section{Anna Magdalena Andrzejewska}

Przedstawicielka Związku Dużych Rodzin „Trzy Plus”

Socjolog, specjalista ds. problemów rodziny

\section{Sytuacja polskiej rodziny w kontekście prowa- dzonej polityki rodzinnej}

Jednym z najważniejszych elementów polityki państwa jest - obok polityki gospodarczej i finansowej, rolniczej ekologicznej i międzynarodowej-polityka społeczna. W ramach polityki społecznej można wyróżnić politykę zdrowotna, rodzinną czy kulturalną. W poniższym artykule zajmę się polityką rodzinną jako szczególnym elementem polityki społecznej.

Polityka rodzinna może mieć różne oblicza. Najważniejszym elementem polityki rodzinnej jest określenie miejsca rodziny i jej szczególnej roli w państwie i społeczeństwie. Jest to szczególnie ważne w państwie, w którym system zabezpieczenia społecznego opiera się na solidarności pokoleń. Polityka społeczna powinna określać, jaka jest pożądana struktura społeczna państwa obejmująca takie miary jak: liczebność społeczeństwa, struktura wiekowa, wykształcenie w poszczególnych grupach wiekowych i społecznych za 5, 10, 20 i 50 lat, oraz jakie działania powinno podjąć państwo i jakie przeznaczyć środki już dziś i w przyszłości, żeby to osiągnąć powyższe cele. Przykładowe działania ze strony państwa to chociażby:

- ochrona życia poczętego i małych dzieci poprzez szeroki zakres pomocy matkom i rodzinie oraz wspieranie rozwoju rodziny nie tylko w układzie nuklearnym,

- promowanie rodziny wielopokoleniowej jako najlepszego układu solidarności między pokoleniami (duży potencjał społeczny tkwi w osobach starszych, które przechowują tradycje i doświadczenie poprzednich pokoleń), 
- promowanie zdrowego trybu życia rodziny (jej funkcji wychowawczej i zdrowotnej),

- polityką rodzinną jest także promowanie antykoncepcji, aborcji, eutanazji, co oczywiście jest najbardziej jaskrawym przykładem prowadzenia pewnej „polityki wobec rodziny".

Dla potrzeb niniejszego artykułu przyjmuję definicję polityki rodzinnej, rozumiejąc ją jako: całokształt norm prawnych, działań i środków przeznaczanych przez państwo w celu stworzenia odpowiednich warunków życia dla rodziny, jej powstawania, prawidłowego funkcjonowania i pełnienia przez nią wszystkich ważnych społecznie ról1 ${ }^{1}$ Tak rozumiana polityka rodzinna nasuwa jednoznaczny wniosek, że każde działanie podjęte przez państwo, nawet jeżeli nie jest to jego celem, ma wpływ na rodzinę rozumianą jako podstawowa grupa społeczna, na której opiera się społeczeństwo ${ }^{2}$. Nie ma znaczenia, jakiego dotyczy obszaru: finansów, służby zdrowia czy bezpieczeństwa narodowego. Zastanawiające jest, że w ustawodawstwie polskim sprawdza się ustawy pod kątem ich wpływu na ochronę środowiska, rynek pracy itp., ale nie bada się wpływu ustaw na rodzinę! Oddzielnym elementem polityki rodzinnej jest polityka edukacyjna zarówno w odniesieniu do opieki i edukacji pozarodzinnej dedykowanej małym dzieciom, jak również do opieki i edukacji dzieci i młodzieży w różnych grupach wiekowych. Dobrze zrównoważona polityka rodzinna jako element polityki społecznej ma również pożądany wpływ na rozwój gospodarczy kraju. Polityka rodzinna obejmuje politykę migracyjną - zarówno emigracja z Polski, jak i sposób przyjmowania imigrantów i repatriantów ma wpływ na rozwój społeczeństwa (w tym politykę edukacyjną i kulturalną oraz rozwój gospodarki kraju).

Por. A. Kuzynowski, Rodzina w polityce społecznej państwa, Centralny Program Badań Podstawowych, Warszawa, 1991, s. 8-9.

2 Por. Z. Tyszka, Rodzina w świecie współczesnym - jej znaczenie dla jednostki i społeczeństwa, w: Pedagogika społeczna, red. T. Pilch, I. Leparczyk, Wydawnictwo Żak, Warszawa 1995, s. 137. 
Przedstawiciele wszystkich stron areny politycznej mówią wiele o polityce rodzinnej, warto więc (zwłaszcza w kontekście myślenia o Polsce jako kraju opiekuńczym) przyjrzeć się wchodzącym w życie ustawom dotyczącym rodziny bezpośrednio. Powstaje wiele ustaw dotyczących rodziny w oderwaniu od sytuacji społecznej polskiej rodziny. Poniżej przedstawię niektóre $\mathrm{z}$ nich.

Pierwsza ustawa, którą chciałam w skrócie omówić, jest Ustawa z dnia 4 lutego 2011 r. o opiece nad dzieckiem do lat trzech. Otóż ustawa ta w żaden sposób nie uwzględnia opieki rodzicielskiej nad dzieckiem - pieniądze idą za dzieckiem jedynie do instytucji. Ustawodawcy umyka rodzina, która chce mieć możliwość wyboru sposobu wychowania dziecka. Jednym słowem, celem ustawy jest zapewnienie dziecku do lat trzech opieki tylko i wyłącznie zinstytucjonalizowanej, a nie opieki uwzględniającej jej wszystkie formy (w tym wychowanie w rodzinie). Rodzicom zostaje narzucone zinstytucjonalizowane wychowanie dziecka, podczas kiedy to właśnie dzieci wychowywane $\mathrm{w}$ rodzinie (zwłaszcza w rodzinie wielopokoleniowej), a nie przez instytucje, zyskują wartość, jaką jest świadomość potrzeb wszystkich członków rodziny w różnym wieku i świadomość solidarności pokoleniowej na przykładzie relacji, obserwacji życia rodziny i w ramach działań podejmowanych na rzecz rodziny i domu. Nie wolno zapominać, że wszystkie badania psychologiczne wskazują jednoznacznie, że dziecko w pierwszych trzech latach pod względem emocjonalnym najlepiej rozwija się w rodzinie. Niedobory edukacyjne, jakie może mieć dziecko w domu (rodzic oczywiście często poświęca na edukację dziecka mniej czasu), maluchy są w stanie nadrobić bardzo szybko, jednak nic nie jest w stanie uzupełnić niedoborów emocjonalnych powstających w dziecku oddanym pod opiekę instytucji w pierwszych latach jego życia. System promuje pracę zawodową kobiet, pomijając potrzeby emocjonalne zarówno dziecka, jak i matki, a w wielu przypadkach pomijając także finansowe potrzeby rodziny. Jeżeli budżet państwa jest przygotowany 
na finansowanie pobytu w żłobku i przedszkolu wszystkich polskich dzieci, to czemu te środki nie mogą trafić do rodziców, zwłaszcza, że często zarobki rodziny nie wystarczają na pokrycie kosztów pobytu dziecka w placówce. Rodzice mają prawo do samodzielnego wychowania i edukacji dzieci, szczególnie w pierwszym okresie ich życia. Przeznaczanie środków na rozwój placówek wychowawczych z pominięciem rodziny dyskryminuje tych, którzy sami chcą wychowywać swoje dzieci. W sytuacji rodzin wielodzietnych, z trojgiem i więcej dzieci, często pójście mamy do pracy nie jest możliwe ze względów logistycznych - ustawa dyskryminuje zatem osoby pracujące $\mathrm{w}$ domu. Fundamentalnym zagrożeniem dla rodziny jest brak ekonomicznych podstaw do jej budowania. Jest to najbardziej zauważalny element prowadzonej polityki. Konstrukcja prawa wspierająca zinstytucjonalizowane wychowanie bez wsparcia rodziców decydujących się na osobistą opiekę nad dzieckiem, to szantaż ekonomiczny, a przymusowa praca matek, to współczesna forma niewolnictwa głęboko ingerująca w funkcjonowanie współczesnej rodziny. Z badań Światowego Ruchu Matek sekcji europejskiej, przeprowadzonych w ramach dużego projektu europejskiego „Family Platform” wynika, że tylko $11 \%$ kobiet jest silnie związana ze swoją pracą zawodową. Dodatkowo, znowu w polskiej regulacji prawnej nie uwzględniono dobra dziecka: dziecko do roku czasu rozłąkę z mamą odczuwa tak silnie, że dorosły człowiek umarłby, przeżywając takie emocje.

Oczywiście, trudno pominąć aspekt ekonomiczny pracy w domu. Przypomnę więc skrótowo, że:

- Badania noblisty Gary'ego Beckera wyceniają wkład pracy wykonywanej w domu przez kobiety na 30\% PKB każdego kraju, chodzi tu o liczne wewnątrzrodzinne zadania, jak edukacja i wychowanie dzieci, opieka zdrowotna itp.;

- Badania OECD (Organizacja Współpracy Gospodarczej i Rozwoju) nad pracą nieodpłatną w niektórych 
dziedzinach podają wartość 50\% PKB, czyli jeszcze więcej niż Gary Becker.

Kolejna ustawa pokazująca tendencje w polityce rodzinnej, to Ustawa z dnia 2 lipca 1991 r. o podatku dochodowym od osób fizycznych. Za rządów SLD (1999-2004) zlikwidowano Fundusz Alimentacyjny. Prawo, które w to miejsce uchwalono (ustawa o świadczeniach rodzinnych z 28 listopada 2003 r. Dz. U. Nr 288, poz. 2255 ze zm.), preferowało i nadal preferuje osoby samotnie wychowujące dzieci, co z kolei doprowadziło w krótkim czasie do znacznego (w samym 2004 roku o blisko 8 tys.) wzrostu rozwodów, zwłaszcza wśród rodzin z dwojgiem i więcej dzieci3. Przykładem „prorodzinności” w ustawie o podatku VAT może być porównanie VAT-u na pieluszki, który wynosi $23 \%$, z tym na prezerwatywy $-8 \%$ !

Ustawa z dnia 29 lipca 2005 r. o przeciwdziałaniu przemocy w rodzinie (nowelizacja 2011; już sam tytuł ustawy, deprecjonuje rodzinę, przedstawiając ją jako komórkę „przemocową"), ingeruje silnie w metody wychowawcze rodziny, kładąc nacisk na ,jedynie słuszne”, stając się jednocześnie narzędziem cenzury dla np.: literatury poradniczej (przykładem jest wycofanie ze sprzedaży książek Oficyny Wydawniczej „Vocatio”: „Mądra miłość" i „Jak trenować dziecko").

Budzącą naprawdę duże emocje jest Ustawa $\mathrm{z}$ dnia 20 kwietnia 2004 r. o promocji zatrudnienia i instytucjach rynku pracy (nowelizacja z 2011 r.). Art. 33 pkt 4d (Dz.U.08.69.415) brzmi: Starosta nie może pozbawić statusu bezrobotnego kobiety w ciaży oraz w okresie 30 dni po dniu porodu z powodu zwiąanej z ciąża i porodem niezdolności do pracy trwajacej przez nieprzerwany okres 90 dni, o którym mowa w ust. 4 pkt 9, z wyłaczeniem przypadku złożenia wniosku o pozbawienie tego statusu przez samą bezrobotna. W praktyce zapis ten oznacza, że kobieta 30 dni po porodzie ma sta-

3 Por. J. Hrynkiewicz, Polityka społeczna wobec rodzin wielodzietnych. Materiały z konferencji "Duże Rodziny bogactwem $i$ nadzieja Polski", Warszawa 2009, s. 129. 
wić się w urzędzie pracy, aby nie stracić przysługujących jej świadczeń! Przypomnę jedynie, że połóg to okres trwający sześć tygodni, w czasie którego dochodzi do cofania się większości zmian, które zaszły w organizmie kobiety w czasie ciąży i porodu. To czas fizjologicznie trudny, wymagający od matki szczególnej dbałości o zdrowie. Tymczasem ustawodawca nakazuje kobiecie chorej stawienie się w urzędzie pracy, przyjęcie oferty, jeżeli zostanie jej takowa przedstawiona, zostawienie niemowlęcia w pierwszych miesiącach życia pod opieką - oto kolejne pytanie - czyją?! To zapis, którego głupotę, ignorancję i antyrodzinność trudno nawet opisać...

Inne ustawy „wspierające rodzinę", to między innymi:

- ustawa emerytalna, nie uwzględniająca, że większość funkcji opiekuńczych podejmowana jest w rodzinie;

- ustawa o informacji oświatowej, gdzie bez zgody rodziców i prawnych opiekunów gromadzone są wrażliwe dane o każdym uczniu, w tym także o sytuacji rodzinnej;

- ustawy edukacyjne nie uwzględniające rozwoju dzieci, a jedynie ich szybsze wejście na rynek pracy.

Krótko podsumowując:

- wszelkie ustawy dotyczące zmian społecznych nie są w żaden sposób badane pod względem ich skutków dla rodziny i rozwoju społeczeństwa;

- od okresu transformacji Polska prowadzi politykę rodzinną i społeczną bez uwzględnienia w niej interesów rodziny, czyli antyrodzinną, o czym świadczą konkretne przykłady ustaw;

- poza Konstytucją RP trudno w polskim ustawodawstwie znaleźć ustawę uwzględniającą rzeczywiste prawa rodziny jako podstawowej komórki społecznej. 


\section{Zuzanna Krogulec}

\section{Wielodzietne rodziny uczestników Drogi Neokatechumenalnej}

Od samego początku uczestnictwa w Drodze Neokatechumenalnej interesowały mnie rodziny wielodzietne, które spotyka się często w tym ruchu Kościoła rzymskokatolickiego. Zastanawiało mnie,

co powoduje rodzicami licznego potomstwa, że decydują się mieć tyle dzieci. Jakie są ich intencje? Jakimi ludźmi sa, że podejmują taką decyzję? Jak żyja, mieszkaja funkcjonują? Dlatego, kiedy nadarzyła się okazja, wykorzystałam ja aby ich o to zapytać. Postanowiłam napisać pracę magisterska, w której odkryję przyczyny wielodzietności, co można wykorzystać do sformułowania wniosków i zaleceń dla polityki prorodzinnej państwa. Do tego celu wykorzystałam metodę badawczą wywiadów pogłębionych, polegającą na wywiadach z członkami Drogi. Praca magisterska pt. Rodziny wielodzietne z Drogi Neokatechumenalnej. Motywacje i wyzwania powstała w 2010 roku.

Rodziny wielodzietne stanowią w Polsce niewielki odsetek rodzin z dziećmi, wynoszący na początku nowego tysiąclecia $16,8 \%{ }^{1}$. Natomiast najbardziej popularnym i akceptowanym modelem rodziny jest model rodziny małodzietnej 2+2 (rodzice i dwoje dzieci) ${ }^{2}$. To samo potwier-

Por. Narodowy spis powszechny. Gospodarstwa domowe i rodziny. Polska, Zakład Wydawnictw Statystycznych, Warszawa 1990, s. 55, 59, 63; Spis ludności i mieszkań metoda reprezentacyjna 1995. Gospodarstwa domowe i rodziny. Polska, Główny Urząd Statystyczny, Warszawa 1996, s. 100; Narodowy spis powszechny ludności i mieszkań. Powszechny spis rolny 2002. Gospodarstwa domowe $i$ rodziny, Zakład Wydawnictw Statystycznych, Warszawa 2003, s. 46-47.

2 Por. Potrzeby prokreacyjne oraz preferowany $i$ realizowany model rodziny, oprac. B. Roguska, Komunikat CBOS BS/52/2006, s. 1-3, <http://www. 
dzają statystyki: od ponad dwudziestu lat współczynnik dzietności ${ }^{3}$ wskazuje natężenie urodzeń na poziomie niższym od prostej zastępowalności pokoleń, z utrzymującą się tendencją spadkową. Oznacza to, że większość kobiet rodzi dwoje dzieci lub mniej, podczas gdy do zachowania stabilizacji liczebnej kolejnych generacji potrzebne jest troje lub dwoje. Stanowi to problem dla instytucji państwa, ponieważ utrzymanie ich zależy od liczebności osób pracujących. Im mniejsze jest następne pokolenie pracujących, tym mniejsze są przychody z podatków, które są potrzebne do utrzymania instytucji sektora państwowego. Państwo już obecnie jest zadłużone ponad miarę w 2008 r. dług publiczny wyniósł 104,9\%4. W perspektywie jest wzrost zadłużenia, spowodowany m. in. wejściem w wiek emerytalny pokolenia wyżu powojennego.

Od lat 70. XX w. za rodzinę wielodzietną uznaje się rodzinę z co najmniej trojgiem dzieci. Wcześniej to pojęcie odnosiło się do rodzin większych, z co najmniej czworgiem dzieci. Zmiana została wprowadzona na wniosek specjalistów polityki społecznej, którzy w wyniku badań dostrzegli związek pomiędzy pojawieniem się trzeciego dziecka w rodzinie a obniżeniem standardu życia jej członków. Włączenie rodzin z trojgiem dzieci do definicji wielodzietności miało na celu materialną pomoc państwa dla tych rodzin 5 .

cbos.pl/SPISKOM.POL/2006/K_052_06.PDF>, (dostęp: 10.08.2012).

3 Współczynnik dzietności, całkowity współczynnik dzietności, Total Fertility Rate (TFR) - określa średnia liczbę dzieci, która urodziłaby kobieta w ciagu całego okresu rozrodczego, zakładając, że intensywność urodzeń pozostałaby niezmienna na poziomie roku badanego. J. Balicki, E. Frątczak, Ch. B. Nam, Przemiany Ludnościowe. Fakty - interpretacje - opinie, Wydawnictwo Uniwersytetu Kardynała Stefana Wyszyńskiego w Warszawie, Warszawa 2007, s. 86.

4 Por. M. Górski, Struktura systemu finansowego gospodarki, w: Wprowadzenie do finansów i rachunkowości, red. M. Górski, Wydawnictwo Naukowe Wydziału Zarządzania Uniwersytetu Warszawskiego, Warszawa 2010, s. 256.

5 Por. D. Graniewska, Pracownicze rodziny liczebnie duże w Polsce, Komitet Pracy i Płac, Warszawa 1971, s. 88-91; D. Graniewska, B. Balcerzak-Paradowska, Rodziny wielodzietne w Polsce. Problemy społeczno-ekonomiczne, 
Rodziny wielodzietne są w Polsce przedmiotem badań głównie polityki społecznej i demografii. Podstawowym źródłem informacji są spisy powszechne. Następnie wiedzy mogą dostarczyć dane kościelne (Kościoła rzymskokatolickiego), które są niepełne, ponieważ nie dotyczą wszystkich rodzin, np. tych odmiennego wyznania. $\mathrm{Z}$ najbardziej wiarygodnych publikacji, jakimi są wydawnictwa statystyki publicznej, można dowiedzieć się o tym, do jakich kategorii społecznych najczęściej przynależą rodzice wielodzietni. Wśród nich wyróżnia się osoby o niskim poziomie wykształcenia, utrzymujące się z pracy w gospodarstwie rolnym, zamieszkałe na wsi, rodziny w niekorzystnej sytuacji materialnej, o dochodzie rozporządzalnym ${ }^{6}$ niższym od przeciętnego, a także osoby pochodzące z rodzin o większej liczbie dzieci niż przeciętna ${ }^{7}$ W polskim społeczeństwie utrwalił się negatywny wizerunek rodzin wielodzietnych jako dysfunkcyjnych.

W wyniku obserwacji stwierdziłam, że rodzice wielodzietni uczestniczący w Drodze Neokatechumenalnej różnią się pod wieloma względami od statystycznego

Instytut Pracy i Spraw Socjalnych, Warszawa 1979, s. 5.

6 Dochód rozporządzalny obejmuje pieniężne i niepieniężne (...) bieżace dochody gospodarstwa domowego, pomniejszone o podatki od dochodów, spadków i darowizn oraz nieruchomości. Przeznaczony jest na cele konsumpcyjne, pozostate wydatki oraz przyrost oszczędności. GUS 1997a, s. XVI, cyt. za: D. Graniewska, B. Balcerzak-Paradowska, D. Głogosz, Warunki materialne rodzin wielodzietnych, w: Rodziny wielodzietne w Polsce. Teraźniejszość i przyszłość, red. B. Balcerzak-Baradowska, Instytut Pracy i Spraw Socjalnych, Warszawa 1997, s. 35.

7 Por. Narodowy spis powszechny. Gospodarstwa domowe i rodziny. Polska, dz. cyt., s. 55, 59, 63; Spis ludności i mieszkań metoda reprezentacyjna 1995. Gospodarstwa domowe i rodziny., dz. cyt., s. 100; Narodowy spis powszechny ludności i mieszkań. Powszechny spis rolny 2002. Gospodarstwa domowe $i$ rodziny, dz. cyt., s. 50-51, 54-55, 176-179, 194-201; D. Graniewska, B. Balcerzak-Paradowska, Rodziny wielodzietne w Polsce. Problemy społeczno-ekonomiczne, dz. cyt., s. 18-20; B. Balcerzak-Paradowska, D. Głogosz, Rodziny wielodzietne, w: Rodziny w Polsce. Ewolucja. Zróżnicowanie. Okres transformacji, red. S. Golinowska, B. Balcerzak-Paradowska, Instytut Pracy i Spraw Socjalnych, Warszawa 1995, s. 171-174; D. Graniewska, B. Balcerzak-Paradowska, Wielodzietność jako cecha środowiskowa, w: Rodziny wielodzietne w Polsce. Teraźniejszość i przyszłość, dz. cyt., s. 9, 14, 20, $36,39$. 
obrazu rodziców wielodzietnych. Moi rozmówcy mieli wykształcenie średnie lub wyższe, a także podobnie różnili się wykonywanym zawodem, miejscem zamieszkania, poziomem zamożności i dochodów. Do tego należy dodać, że większość respondentów pochodziła z rodzin małodzietnych. Stąd można wyciągnąć wniosek, że ich wielodzietność nie jest wzorem odziedziczonym, a wynikiem świadomej decyzji. Dlatego analiza konkretnych przypadków możne być podstawą do sformułowania skutecznych zachęt do poszerzenia rodziny.

Droga Neokatechumenalna jest ruchem religijnym w ramach Kościoła rzymskokatolickiego, powstałym w 1964 r. w Hiszpanii ${ }^{8}$. Jej celem jest ponowne odkrywanie chrześcijańskiego wtajemniczenia dorosłych już ochrzczonych, lecz dotąd niedostatecznie katechizowanych. Neokatechumenat proponuje wieloletnią formację, aby „wychować” jej uczestników do dojrzałej wiary ${ }^{9}$. Droga została zatwierdzona w obecnej formie w 2008 r. Jej główne założenia to wspomniana wyżej formacja katolicka jej uczestników poprzez proklamację nauki zgodnej z doktryną Kościoła. Akcentuje się takie elementy dorobku Kościoła, jak misyjność i rodzina chrześcijańska. Formacja następuje w małej wspólnocie, która spotyka się dwa razy w tygodniu. Co tydzień celebruje się liturgię słowa i Eucharystię (specjalną dla uczestników Drogi). Szczególne znaczenie ma także czytanie Pisma świętego ${ }^{10}$.

Jak już wspomniałam wyżej, badania wykorzystane do mojej pracy magisterskiej zostały przeprowadzone metodą wywiadów pogłębionych. Jest to metoda badawcza stosowana do eksploracji zjawisk trudnych lub mało znanych. Do takich zalicza się np. religijność. Badania

Por. E. Pasotti, Nota historyczna, w: Neocatechumenale Iter. Statuta, Lublin b. d. w., s. 125; Dekret Papieskiej Rady Do Spraw Świeckich 1390/02/AIC110, w: Neocatechumanale Iter. Statuta, Centrum Formacji Wspólnot Neokatechumenalnych Archidiecezji Lubelskiej, Lublin b. d. w., s. 11.

9 Por. Statut Drogi Neokatechumenalnej, w: Neocatechumenale Iter. Statuta, Centrum Formacji Wspólnot Neokatechumenalnych Archidiecezji Lubelskiej, Lublin 2008, s. 26.

10 Por. tamże, s. 34-51, 56-62. 
zostały zrealizowane w pierwszej połowie 2010 r. Wzięły w nich udział osoby zamieszkałe w Warszawie i miejscowościach położonych nieopodal. Wszyscy respondenci byli jednak związani z Warszawą za sprawą swojego miejsca pracy, szkół dzieci czy parafii, w której realizowali Drogę. Narzędziem badawczym był scenariusz wywiadu. Znajdowały się w nim pytania poruszające kwestie takie jak: poglądy na temat rodziny i wielodzietności wynikające ze społecznych cech respondentów i inspiracji czerpanych z otoczenia, wpływ Drogi Neokatechumenalnej na postawy respondentów względem rodziny i wielodzietności, obecne życie respondentów i konsekwencje ich postaw, a na końcu pytania „metryczkowe”. Respondentów podzielono na trzy grupy, różniące się pod względem wieku, stanu cywilnego i liczby dzieci. Było to spowodowane założeniem, że poglądy mogą się różnić w zależności od wieku i stanu cywilnego. Te grupy to młode osoby stanu wolnego, młodzi małżonkowie, rodzice wielodzietni. Przeprowadziłam piętnaście wywiadów ${ }^{11}$.

Charakterystyczne dla badań w formie wywiadów jest poruszanie przez respondentów wielu wątków nie związanych ściśle z badanym tematem. Dzięki temu otrzymuje się bardziej dokładny obraz sytuacji i wiele informacji dodatkowych, które z kolei mogą doprowadzić do nieoczekiwanych wniosków. Tak było również w przypadku moich badań. Wywiady dostarczyły wiele różnorodnych informacji na temat rodzin wielodzietnych, np. organizacji ich życia rodzinnego czy wzajemnych relacji członków rodziny. Jednak w przypadku moich badań najważniejsze było poznanie przyczyn, które powodują rodzicami licznego potomstwa, że mają wiele dzieci. Przeprowadzone wy-

11 Wnioski z badań, scenariusz wywiadu, a także niektóre wywiady w całości, zostały opublikowane w pracy magisterskiej mojego autorstwa pt. Rodziny wielodzietne z Drogi Neokatechumenalnej. Motywacje i wyzwania, obronionej na Uniwersytecie Kardynała Stefana Wyszyńskiego w Warszawie, Wydziale Nauk Historycznych i Społecznych w 2010 r. Cytaty wykorzystane $\mathrm{w}$ tym artykule pochodzą z przeprowadzonych przeze mnie wywiadów, będących w postaci nagrań cyfrowych w moim archiwum. 
wiady doprowadziły mnie do kilku wniosków. Oto one.

Najważniejszą przyczyną wielodzietności wśród uczestników Drogi Neokatechumenalnej jest przykład innych rodzin wielodzietnych i przebywanie w ich towarzystwie. Wśród uczestników Drogi Neokatechumenalnej jest wiele rodzin wielodzietnych. Jest to spowodowane najpierw położeniem akcentu $\mathrm{w}$ formacji na prowadzenie chrześcijańskiego życia rodzinnego. Jednym z jego aspektów jest „otwartość na życie”. Następnie przyszli rodzice obserwują rodziny wielodzietne i to zachęca ich do powielenia tego wzoru, ponieważ w wyniku tych obserwacji wyciągają pozytywne wnioski. Poniżej znajdują się cytaty z wypowiedzi respondentów, uzasadniające taką tezę.

Ojciec dziewięciorga dzieci: (...) Poznaliśmy ludzi, którzy sa we wspólnocie, nasi znajomi ze studiów. (...) zobaczyliśmy inny świat. (...) małżeństwa z szóstka, siódemka, ósemka dzieci, niektórzy bardzo biedni, niektórzy bardzo zasobni, ale bardzo szczéśliwi. Ten wpływ środowiska, (...) we wspólnocie byt istotny (...) myślę, że był decydujacy (...).

Matka czworga dzieci: (...) sama Droga ma ogromny wptyw na moja świadomość, też myśle, że dodawało mi odwagi, jak widziałam rodziny, które maja wiele dzieci i daja sobie rade, te dzieci sa dobrze wychowane (...).

Respondenci pochodzący $\mathrm{z}$ rodzin wielodzietnych (z co najmniej trojgiem lub czworgiem dzieci) byli bardziej skłonni sami mieć wiele dzieci, niż rodzice z rodzin małodzietnych. Taka rodzina wydawała im się naturalna, byli oswojeni z takim typem rodziny, nawet jeśli początkowo planowali mieć mniej dzieci niż ich rodzice. Potwierdza to tezę o wpływie obserwacji rodzin wielodzietnych na powielenie tego wzoru.

Ojciec ośmiorga dzieci: (...) Rodzina moja jest wielopokoleniowa, potężne klany to sa, to nie jest żadna nowość. Mój tata siedmioro, moja mama dziewięcioro rodzeństwa (...) Ja w tej chwili mam tylko siostre jedna, umarł mi brat $i$ zamordowano mi siostre. Było nas czworo.

Matka dziewięciorga dzieci: (...) Mam pięcioro rodzeństwa. Ja jestem szósta. (...) Nie zakładałam, że będę miała wię- 


\section{Część II}

Opinie, relacje, sprawozdania, świadectwa

cej dzieci niż dwoje, będąc, wzrastając w rodzinie wielodzietnej. I tak na dobra sprawe to, że mam więcej dzieci, to byt wptyw Neokatechumenatu. (...) Na katechezach, na różnego rodzaju sesjach, jest tak mocno zgłębiony temat rodziny, dzieci, małżeństwa $i$ to, myśle, że spowodowało, że otworzyły mi się oczy na to, że moje istnienie - to nie jest taki fakt oczywisty. (...) Nie musiałam się urodzić, że (...) życie - jest darem, (...) rzeczywiście Pan Bóg po coś... dał mi szansę się urodzić, (...) nie każdy ma tę szansę $i$ to też postawiło mnie w takiej pozycji (...) pewnej wdzięczności $i$ tego, że... że ja tak dobrze swojego życia nie zaplanuje.

Istotne jest także, że sytuacja materialna i mieszkaniowa nie ma decydującego wpływu na poglądy respondentów na temat wielodzietności. Respondenci nie czekali najpierw na osiągnięcie stabilizacji dochodowej, aby później zdecydować się na dzieci.

Ojciec dziewięciorga dzieci: (...) pracowałem trzeci rok. (...) może była to jakaś tam średnia krajowa, może troszke więcej. Mieszkaliśmy w wynajmowanym domu, pilnując go de facto (...) było trzecie dziecko (...) próbowaliśmy mieć własny kąt, który w większości (...) byt takimi rodzinnymi kredytami rwanymi budowany (...).

Matka siedmiorga dzieci: (...) Przed pojawieniem się trzeciego dziecka nasza sytuacja materialna

$i$ mieszkaniowa była dobra. (...) Zmienito się o tyle, że $w$ momencie, jak przybywało dzieci, mieszkanie się nie zmienito (...).

Ojciec ośmiorga dzieci: (...) pieniądze u nas nie miały wptywu na to, że się rodzity dzieci. (...) Materialna sytuacje mieliśmy taka, jak każdy (...) [wcześniej] Myśmy wynajmowali mieszkania, na dziko mieszkaliśmy, na jednym łóżku polowym spaliśmy, jak pierwsze dziecko mieliśmy (...).

Polityka państwa powinna wspierać takie zachowania obywateli, które są korzystne dla instytucji państwowych. Do zachowań korzystnych można zaliczyć posiadanie rodziny wielodzietnej, ponieważ urodzenie i wychowanie wielu dzieci powoduje stabilizację liczebną lub wzrost następujących po sobie generacji. Natomiast spadek li- 
czebny kolejnych generacji może zagrozić istnieniu wielu instytucji. Dlatego państwo powinno wspierać rodziny wielodzietne, tworzyć odpowiednie zachęty do rodzicielstwa, aby obiektywnie „opłacało się" wychowywać dzieci. Wiadomo, że wielodzietność niesie zwiększenie obciążeń rodziców, zarówno materialne, jak i obowiązkami rodzinnymi. Dlatego, na podstawie wniosków ze swoich badań, sformułowałabym następujące zalecenia dla polityki prorodzinnej, których wprowadzenie zachęciłoby do zakładania większych rodzin. Pierwsze dotyczą popularyzacji wielodzietności w mediach poprzez kampanie społeczne. Należy rozpowszechnić pozytywny wizerunek rodziny wielodzietnej, przedstawiać w mediach pozytywne przypadki takich rodzin, takie jak te, które zachęciły rodziców uczestniczących w Drodze Neokatechumenalnej. Samo stworzenie świadomości jakiegoś zjawiska jest pierwszym krokiem do zmian w jego postrzeganiu. Następnie potrzebne są realne udogodnienia, $\mathrm{np}$. podatkowe dla rodzin $\mathrm{z}$ trojgiem i więcej dzieci - aby przekonać ludzi, że dzieci „opłaca się” mieć i aby wcześniejsza kampania społeczna była skuteczna. Przykładem wspierania rodzin wielodzietnych poprzez system podatkowy jest zmniejszanie obciążeń podatkowych za sprawą urodzenia kolejnego dziecka. Jest to zrozumiały system, w którym władze nie redystrybuują dóbr, przyznając zasiłek, a jedynie zmniejszają obciążenia podatkowe. Taka forma wzmacnia przedsiębiorczość rodziców, wykluczając jakąkolwiek niechęć ze strony otoczenia, która powstaje w przypadku pobierania świadczeń. Możliwe są również inne rozwiązania w zakresie polityki prorodzinnej. Ważne jest jednak, aby tworzyły spójny system, dając sygnał społeczeństwu, że postępowanie zgodne z dobrem publicznym jest wspierane. 


\section{The large families of members of the Neocatechumenal Way}

\section{Summary}

The author of this article was interested in factors which may determine decision of having a large family. Inspiration came from large families participating in the Neocatechumenal Way, which are common in this Roman Catholic Church movement. But contrary to families engaged in the Neocatechumenal Way, huge majority of Polish families consist of less than three children. As a result of constant decline in number of births a family with three children or more in Poland is considered to be a large one. Because decline in births is disadvantageous for society families shall be encouraged to give birth to more than two children by support of governmental and local authorities' policies. An effective policy shall be based on research in this field. The author made a research in 2010 to discover what reasons encourage people to give birth to many children. This research was made by the method of individual deep interviews. The results and conclusions were published in master's thesis entitled Large families of the Neocatechumenal Way. Motivations and challenges written by Zuzanna Krogulec in 2010. The most important conclusion is that the major factor which determines decision of a large family is observation of other large families already participating in the Neocatechumenal Way. These observations lead to positive conclusions and are a strong incentive for future parents to replicate this pattern of a family. This is confirmed by the fact, that those parents who were raised in large families were more likely to give birth to more children than average. The reason was that they had been raised in such a family and it was normal for them. Finally, one of the important conclusions was that financial situation of a young family do not prevent them from intention of having a large family. These conclusions may provide a good base in order to support families. 

Małgorzata Pawlus

Instytut Politologii UKSW

\section{Sprawozdanie z konferencji Kościót wobec kryzysu demograficznego w Polsce w Falenicy w dniach 17-19 czerwca 2012 r.}

Ogólnopolska konferencja sekcji wykładowców katolickiej nauki społecznej, która miała miejsce w dniach 17-19 czerwca 2012 roku w Falenicy, została poświęcona problemom demograficznym i nosiła tytuł Kościół wobec kryzysu demograficznego w Polsce.

Referaty i przeprowadzona dyskusja obejmowały trzy zasadnicze sesje:

I. Demograficzny pejzaż i przyszłość Europy;

II. Kryzys demograficzny - perspektywa jednostki, państwa, Kościoła;

III.Kryzys demograficzny w Polsce - rodziny wielodzietne.

W pierwszym referacie p. Lucyna Nowak (Departament Badań Demograficznych GUS) przedstawiła perspektywy rozwoju demograficznego Polski w nawiązaniu do wyników spisu ludności z 2011 r. Omówiona została metodologia spisu, jak również wstępne wyniki. W opinii Nowak, dane spisowe jednoznacznie wskazują na zahamowanie procesu wzrostu liczby ludności Polski powodowane ruchem naturalnym, przy nieznaczącym wpływie procesów migracyjnych. Jej zdaniem powstrzymanie gwałtownego procesu depopulacji i utrzymanie liczby urodzeń na poziomie 400 tys. rocznie wymagałoby znaczących zmian w postawach i zachowaniach prokreacyjnych i rodzinnych. Konsekwencją postępującego spadku liczby urodzeń są przekształcenia w strukturze wieku ludności oraz zmiany w ekonomicznych grupach wieku i starzenie się zasobów siły roboczej. 
Z kolei Krzysztof Lewandowski (Wydział Analiz Migracyjnych MSW) w swoim referacie podjął kwestię: na ile migracje mogą zastąpić spodziewany ubytek polskiej ludności? Omówiona została skala emigracji Polaków (2 mln) i imigracji cudzoziemców (ok. 100 tys.). W odniesieniu do pesymistycznych prognoz demograficznych, znaczące zwiększenie napływu cudzoziemskiej siły roboczej staje się realnym wyzwaniem dla polskiej polityki migracyjnej w zakresie przygotowania i uruchomienia odpowiednich narzędzi i instrumentów służących większemu otwarciu polskiego rynku pracy na imigrantów oraz ich integrację. Autor w szczególności odniósł się do rządowego dokumentu Polityka migracyjna Polski, jak również do prac grupy roboczej ds. integracji cudzoziemców przy Międzyresortowym Zespole ds. Migracji. Najważniejszym celem grupy jest wypracowanie kierunków dla polskiej polityki integracji, dokonane w konsultacji i przy ścisłej współpracy z organizacjami pozarządowymi, w tym również z Caritas Polska.

Druga sesja konferencji dotyczyła kryzysu demograficznego w perspektywie jednostki, państwa oraz Kościoła. Prof. Andrzej Ochocki, w odniesieniu do teorii dzietności Gary S. Beckera, dokonał analizy współzależności decyzji matrymonialnych, prokreacyjnych i aktywności zawodowej matek oraz rzeczywistego przebiegu procesu zastępowalności pokoleń w pięciu państwach: Finlandii, Niemczech, Polsce, Republice Czeskiej i Włoszech. Autor podkreślił potrzebę formułowania nowych hipotez o uwarunkowaniach procesu zastępowalności pokoleń pozbawionych ekonomicznego redukcjonizmu. Zdaniem Ochockiego, przywrócenie naturalnych proporcji pokoleń rodziców i dzieci wymaga nie tylko godziwych dochodów gospodarstwa domowego, rozwiniętej instytucjonalnej opieki nad małymi dziećmi oraz pośrednich transferów finansowych związanych z edukacją i ochroną zdrowia dzieci i młodzieży, ale również upowszechnienia partnerskiego modelu rodziny nuklearnej, kiedy opiekę nad dzieckiem sprawuje także ojciec. Symptomy takiego 
procesu odnotowano już w tych krajach Europy, gdzie konsekwentnie realizowana jest polityka rodzinna, tj. w Finlandii, Francji, Irlandii, Islandii, Norwegii i Szwecji.

Prof. Ewa Frątczak, w swoim wystąpieniu zatytułowanym Przemiany płodności a plany prokreacyjne - Polska, wybrane kraje Europy. Kontekst: welfare state, skupiła się na prezentacji wyników dwóch projektów badawczych. Pierwszy z nich dotyczył planów prokreacyjnych młodych Polek (Diagnoza późnej dzietności - kohortowe badanie prospektywne czynników demograficznych, społeczno-ekonomicznych $i$ zdrowotnych, 2006-2011). Wyniki tych badań były interpretowane $\mathrm{w}$ odniesieniu do wybranych teorii ekonomicznych oraz nieekonomicznych i - zdaniem autorki - nie dają podstawy do optymistycznych wniosków: nie ma możliwości podniesienia dzietności w Polsce, nawet przy dużym podniesieniu nakładów na politykę rodzinna, bowiem kobiety nie realizują planów prokreacyjnych. Drugi omówiony projekt, Reconciling Work and Welfare in Europe. RECWOWE Network of Excellence (2006-2011), miał charakter międzynarodowego networku i dotyczył m.in. analizy intencji prokreacyjnych w pięciu krajach europejskich (Francja, Szwecja, Niemcy, Polska, Węgry). Zdaniem Frątczak interpretacja procesów demograficznych staje się coraz trudniejsza ze względu na tempo przemian i wyczerpanie dotychczasowych koncepcji. Takim nowym trendem dostrzeganym przez badaczy jest dodatnia korelacja między aktywnością zawodową a dzietnością oraz większa dzietność kobiet z wyższym wykształceniem i preferowanie przez nie stylu życia opartego na trwałości związku. Autorka podkreśla potrzebę nowych interpretacji zależności rodziny i płodności i wskazuje na prekursora reinterpretacji roli małżeństwa i rodziny dla procesów prokreacji, prof. Elaine Anderson.

Kolejne wystąpienie, dr Ireny Kowalskiej, dotyczyło zmian w systemie norm i wartości jako determinanty przemian demograficznych. Autorka podjęła kwestię zmiany tradycyjnych wzorców rodziny rozumianych jako utrata tożsamości i zmiana roli rodziny (m.in. utrata funkcji za- 
bezpieczającej, osłabienie lub zaniechanie funkcji socjalizujących). Zdaniem Kowalskiej, jednym z ważnych czynników sprzyjających przemianom rodziny jest pluralizm ideologiczny, a konkretnie rozchodzenie się ideologicznej drogi państwa, Kościoła i rodzin. W tym kontekście omawiana konferencja stała się przejawem dobrej woli budowania szerokiego konsensusu w kwestii rodziny. Autorka w swoim referacie przywołuje dane międzynarodowego projektu badawczego Population Policy Acceptance Study z 2002, w którym podjęto kwestię postaw i zachowań względem dziecka, małżeństwa, rodziny w kontekście preferowanych wartości materialistycznych i postmaterialistycznych. W Europie Środkowo-Wschodniej dominują wartości materialistyczne (m.in. wystarczający dochód, dobre warunki mieszkaniowe), natomiast w krajach zachodnich wartości postmaterialistyczne (m.in. czas dla siebie, samorealizacja). Polska wyróżniała się w tych badaniach wysoką pozycją deklarowanego poparcia dla wartości rodzinnych, a jednocześnie brakiem działań społeczno-ekonomicznych, wspierających dzisiejsze rodziny. Od wielu lat więcej uwagi skupia się na tworzeniu idei pożądanej polityki rodzinnej niż na skutecznym, stopniowym wdrażaniu ustalanych pozytywnych rozwiązań na rzecz rodziny.

Prof. Bożena Balcerzak-Paradowska w swoim wystąpieniu pt. Polityka rodzinna wobec wyzwań demograficznych. Unia Europejska a Polska, w pierwszej kolejności odniosła się do procesów demograficznych i ich skutków, następnie omówiła czynniki wpływające na postawy wobec małżeństwa, dzietności i rodziny. Kluczową częścią jej referatu była kwestia współczesnych uwarunkowań polityki rodzinnej w Polsce, w tym braku klimatu prorodzinnego. Autorka, stawiając pytanie: jaka polityka rodzinna?, podniosła problem, na ile ma mieć ona charakter dostosowawczy, a na ile stymulujący w kontekście potrzeby zahamowania tempa niekorzystnych zmian. Balcerzak-Paradowska, przywołując klasyfikacje polityk rodzinnych wg Espinga-Andersena, postuluje konieczność docenienia 
roli rodziny $\mathrm{w}$ tych modelach, m.in. włączenie w obszar polityki rodzinnej kwestii opieki nad osobami starszymi.

Ks. dr Józef Młyński podjął w swoim referacie temat stosunku Kościoła wobec demograficznych wyzwań. Podkreślił, iż płodność i zrodzenie potomstwa jest ważnym aspektem życia chrześcijańskiego, dlatego Kościół broni dzietności na wielu płaszczyznach: religijnej, kultycznej, ekonomicznej, społecznej i mentalnej. Najważniejszą wartością doczesną w świetle nauki Kościoła jest poszanowanie życia ludzkiego i godności człowieka, który został stworzony na obraz i podobieństwo Boże (Rdz 1,27). Troska Kościoła o godność osobową każdego człowieka i jego rozwój znajduje swój wyraz w działaniach na rzecz ochrony życia ludzkiego od poczęcia do naturalnej śmierci oraz we wspieraniu rodzin, w tym w szczególności rodzin wielodzietnych.

Ważnym aspektem omawianej konferencji było włączenie się w dyskusję, obok ekspertów oraz osób duchownych, przedstawicieli rodzin wielodzietnych. Pani Teresa Kapela, wiceprezes Związku Dużych Rodzin „Trzy Plus” w swoim wystąpieniu podjęła takie kwestie jak: założenia programowe stowarzyszeń rodzinnych funkcjonujących w Europie, stereotypy i realia dotyczące rodziny wielodzietnej w Polsce. Autorka, przywołując motto Europejskiej Federacji Stowarzyszeń Rodzin Wielodzietnych „Rodziny wielodzietne nie są problemem, są rozwiązaniem”, podkreśliła, iż rodziny wielodzietne w obliczu kryzysu demograficznego są faktycznie rozwiązaniem, ale mają też specyficzne potrzeby, których artykulacja i zaspokojenie stało się motywem samoorganizowania się rodzin z większą liczbą dzieci. Pani Kapela podkreśliła, iż brakuje naukowych badań na temat wielodzietności, które mogłyby być podstawą diagnozy, jak i rekomendacji adekwatnych działań w obszarze polityki społecznej.

Referat dr Małgorzaty Pawlus stanowił próbę spojrzenia na wielodzietność z perspektywy kobiety. Autorka odwołała się do symboli i stereotypu Matki-Polki oraz procesu przemiany wzorców macierzyństwa. Podjęta 
została kwestia, na ile kobiety świadomie decydujące się na większą liczbę dzieci wpisują się w model refleksyjnie i podmiotowo przeżywanego nowego macierzyństwa. Pawlus, w odwołaniu do dwuwymiarowej koncepcji sprawiedliwości społecznej Nancy Fraser, postuluje konieczność prowadzenia polityki rodzinnej integrującej skuteczne działania redystrybucyjne z klimatem przyjaznym rodzinie, społecznym uznaniem dla kobiet, które chcą mieć więcej dzieci.

Kolejny referat p. Anny Andrzejewskiej dotyczył sytuacji polskiej rodziny w kontekście prowadzonej polityki rodzinnej z perspektywy środowisk prorodzinnych. Autorka odwołała się m.in. do wybranych ustaw (Ustawa z dnia 4 lutego 2011 r. o opiece nad dzieckiem do lat trzech, Ustawa z dnia 2 lipca 1991 r. o podatku dochodowym od osób fizycznych, Ustawa z dnia 29 lipca 2005 r. o przeciwdziałaniu przemocy $\mathrm{w}$ rodzinie, Ustawa $\mathrm{z}$ dnia 20 kwietnia 2004 r. o promocji zatrudnienia i instytucjach rynku pracy). Zdaniem Andrzejewskiej, od okresu transformacji Polska prowadzi politykę rodzinną i społeczną bez uwzględnienia w niej autentycznych interesów rodziny, o czym świadczą tworzone zapisy ustaw, często nie konsultowane pod względem skutków dla rodziny i rozwoju społeczeństwa.

Polityka państwa w stosunku do rodzin była również tematem referatu Tomasza Józefowicza, w którym dokonano analizy, jak była ona formułowana i realizowana w Polsce od roku 1989 przez poszczególne rządy.

W ostatnim referacie p. Zuzanna Krogulec zaprezentowała częściowe wyniki i wnioski swojej pracy badawczej poświęconej postawom wobec wielodzietności uczestników katolickiego ruchu religijnego Droga Neokatechumenalna. Zdaniem autorki, najważniejszą przyczyną wielodzietności wśród uczestników Drogi Neokatechumenalnej jest przykład innych rodzin wielodzietnych oraz formacja ukierunkowana na prowadzenie chrześcijańskiego życia rodzinnego, którego jednym z aspektów jest „otwartość na życie”. 


\section{Omówienie dyskusji z konferencji Kościót wo- bec kryzysu demograficznego w Polsce w Fa- lenicy w dniach 17-19 czerwca 2012 r.}

\section{Dyskusja nr 1.}

Po pierwszej części konferencji, zatytułowanej Demograficzny pejzaż i przyszłość Europy, w której p. Lucyna Nowak (Departament Badań Demograficznych GUS) wraz z Krzysztofem Lewandowskim (Wydział Analiz Migracyjnych MSW) zaprezentowali polską perspektywę rozwoju demograficznego, rozpoczęła się dyskusja poświęcona problemom przez nich poruszonym.

Jako pierwsza głos zabrała profesor Biruta Skrępowicz. Zaczynając wypowiedź, wyraziła swój niepokój co do próby reprezentacyjnej osób poddanych badaniom socjologicznym (20\% populacji), uważając ją za zbyt małą. Tak niski procent Polaków ujętych w analizie sytuacji na pierwszy rzut oka może nasuwać wątpliwości co do rzetelności prezentowanych wyników badań. Ponadto prof. Skrępowicz wspomniała o "zadziwiającym nieszczęściu Polski”. Takim określeniem nazwała spadek narodzin, jaki wykazały prezentowane dane w stosunku do badań przeprowadzonych po II wojnie światowej. Różnica między współczesnymi a przedwojennymi wynikami wyniosła ponad $40 \%$. Kolejnym problemem, według oceny prof. Skrępowicz, jest wskaźnik dzietności, który co prawda nie uległ znacznym zmianom w ostatnich latach, jednak przy ogromnych zmianach społecznych, nowym modelu funkcjonowania młodych kobiet, powszechnej migracji, może okazać się bezużyteczny przy programowaniu polityki demograficznej na dalsze lata. Nie jesteśmy 
w stanie zapewnić, że ludzie w takich sytuacjach będą zachowywali się w sposób odpowiadający założeniom prowadzących badania. Jako kolejny wskaźnik, mogący okazać się bezużytecznym, wymieniła średnią ilość zgonów. Wskaźnik ten odnosi się bowiem nie do jednostek obecnie dorosłych, lecz do tych, które dopiero się rodzą i może on zostać zniekształcony poprzez kolejne narodziny, co do ilości których nie możemy mieć pewności. Następnie prof. Skrępowicz wskazała na prezentowaną w referatach liczbę osób aktywnych zawodowo, do której wliczeni zostali również bezrobotni, którzy, choć nie wykonują żadnej pracy, to jednak są potencjalnymi pracownikami. W rzeczywistości więc liczba osób aktywnych zawodowo nie równa się liczbie zatrudnionych. $Z$ tego wynika, iż nie każdy aktywny zawodowo przyczynia się do wypracowywania polskiego PKB. Wśród bezrobotnych znajduje się spora liczba osób z wyższym wykształceniem, która ze względu na brak możliwości podjęcia pracy adekwatnej do posiadanego wykształcenia, decyduje się na emigrację zarobkową lub stały pobyt zagranicą. Tam często również nie podejmuje pracy w wyuczonym zawodzie, ale pracuje za wyższe wynagrodzenie niż to, które otrzymałby za taką samą pracę w Polsce.

Kolejny uczestnik ${ }^{1}$ dyskusji podjął kwestię szeroko dyskutowanej sprawy podniesienia wieku emerytalnego. Nurtowało go zagadnienie, na ile decyzja o podniesieniu wieku emerytalnego może poprawić sytuację na rynku pracy. Kolejną sprawa, jaką poruszył pytający, była kwestia szarej strefy, w której zatrudniona jest spora ilość emigrantów z krajów byłego Związku Radzieckiego. Z kolei rozmówca Michał Dybalski, zadał pytanie panu Lewandowskiemu odnośnie do prorodzinnego charakteru dokumentu „Polska 2030” (w którym duży nacisk kładzie się na aktywność zawodową kobiet) oraz stopnia

Dziękując wszystkim uczestnikom dyskusji za ciekawe pytania, sugestie i dygresje, zaznacza się iż w dalszej części tekstu na określenie osób zabierających głos (z wyjątkiem prelegentów), pojawiać się będzie zamiennie sformułowanie: uczestnik lub rozmówca. 
jego realizacji. Następne pytanie dotyczyło polskiej racji stanu $\mathrm{w}$ polityce migracyjnej i wypracowywania przez napływową siłę roboczą polskiego PKB: Czy w polskiej polityce migracyjnej będziemy dążyć do tego, aby polskie PKB wytwarzane było przez pracowników z zagranicy, czy raczej zależy nam na może niższym wskaźniku, ale tworzonym przez samych Polaków?

Po serii pytań prelegenci podjęli próbę odniesienia się do nich. Lucyna Nowak zauważyła, że choć próba reprezentacyjna podczas prowadzonych badań składała się z $20 \%$ populacji, to jednak ułożona została przez specjalistów z zakresu matematyki, a nie socjologów. Próba ta daje rzetelne wyniki na poziomie powiatów i miast. Specjaliści z Uniwersytetu Ekonomicznego zajmą się dodatkowo desegregacją zebranych danych, tak aby były one miarodajne nawet dla gmin i małych miejscowości wiejskich. Rozbieżność wyników próby reprezentacyjnej i badań ekonomicznej aktywności ludzi (BAEL) wynikać mogą ze sporych braków odpowiedzi w ankietach próby reprezentacyjnej. W opinii profesor Nowak, pomimo braków odpowiedzi, próba reprezentacyjna 20\% powinna dawać wyniki bliższe prawdzie niż wskaźnik BAEL.

Odnosząc się do sprawy wydłużenia wieku emerytalnego, L. Nowak uznała obecny czas za najwłaściwszy dla takich zmian. W jej opinii, Polacy nie powinni martwić się perspektywą zajmowania miejsc pracy przez osoby, które do tej pory przechodziłyby na emeryturę. Zmniejszająca się z każdym rokiem liczba ludzi wchodzących na rynek pracy w ciągu najbliższych dziesięciu lat powinna zredukować bezrobocie do bezpiecznego poziomu 3\%, w którym znajdą się osoby, które nie chcą podejmować pracy lub zmieniają ją. L. Nowak stwierdziła, że w prognozie demograficznej są elementy łatwiejsze do przewidzenia (liczba zgonów, przemieszczanie się z jednej grupy wiekowej do drugiej - odnoszące się do osób aktualnie żyjących), jak i elementy trudniejsze (chociażby wspomniana przez prof. Skrępowicz liczba narodzin). Jednak zastoso 
wanie odpowiednich funkcji matematycznych pozwala na rzetelne szacowanie dzietności w kolejnych latach.

Poruszając sprawę polskiej polityki migracyjnej, L. Nowak zauważyła, iż jej stworzenie zależy nie od jednego organu państwa, lecz musi być swego rodzaju kompromisem między poszczególnymi ministerstwami, policją i strażą graniczna, które w różnym zakresie zainteresowane są uregulowaniem tej kwestii. W chwili obecnej pracą nad dokumentem regulującym politykę migracyjną zajmuje się Rada Ministrów. Uzupełnieniem tego projektu miałby być specjalny dokument określający odpowiedzialność poszczególnych organów państwa w zakresie polityki migracyjnej.

Następnie zabrał głos K. Lewandowski, zaznaczając, iż nie czuje się specjalistą od projektu „Polska 2030”. W jego opinii, imigracja nie jest lekarstwem na spadek narodzin w Polsce. Jedynym rozsądnym rozwiązaniem wydaje się sprawna polityka prorodzinna prowadzona przez rząd. Zapewnienie pracy i godziwych warunków życia powinno powstrzymać młodych Polaków przed emigracją i zachęcić do zakładania rodzin. Prelegent stwierdził także, że emigracja przestaje być palącym problemem polskiej polityki migracyjnej. Rynki pracy w zachodniej Europie zaczynają nasycać się pracownikami z ubożejących krajów Unii Europejskiej (jak np. Hiszpania i Grecja), co sprawia, że stają się mniej atrakcyjne dla Polaków. Nawiązując do pytania o szarą strefę, w której zatrudniani są nielegalni imigranci z państw byłego ZSRR, zaznaczył, że według szacunków Urzędu ds. Cudzoziemców szara strefa mieści około siedemdziesiąt tysięcy takich pracowników, z których większość zatrudniona jest w rolnictwie i budownictwie. W zjawisku imigracji nie należy jednak pokładać nadziei na polepszenie wskaźników demograficznych. Badania wykazuja, iż imigranci już w drugim pokoleniu zaczynają przejmować wzorce kulturowe środowisk, w których się osiedlili. Pomimo tego, migracja wykwalifikowanych pracowników jest pożyteczna dla polskiej gospodarki. Tym bardziej, jeśli pracownicy po- 
chodzą z kręgów kulturowo bliskich i łatwo się integruja, a nawet asymilują w nowym środowisku.

Ostatnią kwestią poruszoną przez Lewandowskiego była rzekoma nietolerancja Polaków względem cudzoziemców. Prelegent stwierdził, że nie powinniśmy mówić o nietolerancji, a raczej o braku świadomości. Polacy bowiem w większości [poza zamieszkującymi tzw. regiony pogranicza - dopisek własny] nadal nie są przyzwyczajeni do życia w środowisku wielonarodowym i wielokulturowym - co jest skutkiem wieloletniej izolacji państwa po II wojnie światowej. Na szczęście, sytuacja ta zaczyna się zmieniać i już dziś istnieją miejscowości, w których dzięki skutecznej akcji informacyjnej udało się założyć sprawnie działające ośrodki dla imigrantów.

\section{Dyskusja nr 2.}

Rozpoczynając drugą dyskusję, po sesji poświęconej kryzysowi demograficznemu i europejskiej polityce rodzinnej, prowadzący panel ks. Tomasz Biedrzycki zauważył, że rozwiązanie problemu podwyższenia dzietności i płodności Polek można określić mianem poczucia bezpieczeństwa. Bezpieczeństwo zatrudnionych na rynku pracy, bezpieczeństwo mężów utrzymujących rodziny, bezpieczeństwo matek wychowujących dzieci przy współudziale mężów, poczucie bezpieczeństwa całego społeczeństwa powinny pozytywnie zmienić poziom dzietności i płodności Polek. Brak poczucia bezpieczeństwa powoduje brak zadowolenia z życia i otaczającej rzeczywistości, co w naturalny sposób ma przełożenie na wspomniane wskaźniki. Zdaniem ks. Biedrzyckiego, dawny system polityczny dawał większe poczucie bezpieczeństwa i stabilizacji, pomimo niższego poziomu materialnej sfery życia obywateli oraz ograniczonej wolności obywatelskiej.

Kolejnym, o wiele poważniejszym problemem w kwestii dzietności wydaje się lansowanie kultury, w której przyznanie się do chęci posiadania rodziny i potomstwa 
jest czymś wstydliwym i niemodnym. Taki styl życia często postrzegany jest jako anachroniczny i szkodliwy dla rozwoju jednostki. Kwestiom kulturowym towarzyszy także sprawa sztucznie regulowanej płodności. Przykładem tragicznego w skutkach ograniczania płodności może okazać się obecny gigant gospodarczy - Chiny. Cały świat „drży wobec potęgi Chin”, jednak restrykcyjna polityka demograficzna tego państwa, sztucznie regulująca kwestie płodności (przymusowe stosowanie środków antykoncepcyjnych i aborcji oraz prawne ograniczanie ilości posiadanego potomstwa), może doprowadzić do zachwiania się naturalnej proporcji między ludźmi znajdującymi się w poszczególnych grupach wiekowych, a w konsekwencji doprowadzić do upadku gospodarczego Państwa Środka.

Ponadto, istotne wydaje się opóźnione wchodzenie Polski w kulturę związków partnerskich, w których rodzi się mniej dzieci. Już dziś obserwuje się spadek narodzin, pomimo tego, że Polacy nadal w większości zakładają rodziny. Należy mieć nadzieję, że problem wdzierających się do naszej kultury tzw. wolnych związków, będzie jedynie zjawiskiem przejściowym. O istotnym znaczeniu warunków kulturowych w perspektywie dzietności wśród kobiet świadczą zdaniem prowadzącego dyskusję, nie tylko Stany Zjednoczone, ale i niektóre polskie gminy, jak chociażby Sierakowice (jedna z najlepiej rozwiniętych gmin w Polsce) - gdzie wskaźnik dzietności jest wysoki.

Pierwszy uczestnik dyskusji, dr Aleksandra Ziębińska z Politechniki Śląskiej, zasugerowała rozwiązanie problemu dzietności poprzez stworzenie warunków umożliwiających połączenie rodzicielstwa z pracą zawodową kobiet. Przykładem takiego rozwiązania może być Finlandia, w której młode matki nie są skazane na zasiłki, lecz mogą spokojnie podejmować aktywność zawodową. Perspektywa posiadania dziecka bez rezygnacji z kariery zawodowej i życia kulturalnego miałaby zachęcać młode Polki do zakładania rodzin. 
Następnie dr Michał Michalski z Uniwersytetu Adama Mickiewicza w Poznaniu poruszył temat płacy rodzinnej, dającej młodym kobietom poczucie bezpieczeństwa i od strony psychologicznej zachęcającej do rodzicielstwa. Płaca taka, według koncepcji katolickiej nauki społecznej, powinna pozwolić utrzymać rodzinę jedynie z płacy męża, w sytuacji, gdy żona zajmuje się opieką nad potomstwem. Ponadto dr Michalski zadał pytanie o osobisty stosunek profesor Frątczak do terminu i idelogii gender - coraz bardziej powszechnej w kulturze europejskiej. Kolejnym tematem interesującym dr. Michalskiego okazała się teoria Beckera - głosząca, że praca kobiet w gospodarstwie domowym tworzy około $40 \%$ PKB. Poruszenie tematu Beckera spowodowało natychmiastową reakcję profesora Ochockiego. Stwierdził on, że nie wie, w jakich okolicznościach Becker wypowiedział taką tezę, ale dla Polski rzeczywiście szacuje się ten udział na poziomie zbliżonym do $40 \%$. Zdaniem profesora Ochockiego, teorie Beckera i Andersona są ze sobą kompatybilne. Natomiast płaca rodzinna, zdaniem profesora, może istotnie wpłynąć na zachowania prokreacyjne poprzez zwiększenie poczucia bezpieczeństwa socjalnego.

Po odpowiedziach na postawione wcześniej pytania, głos zabrała dawna współpracowniczka profesora Ochockiego ze Szkoły Głównej Handlowej, dziękując prelegentom za ukazanie społecznej wartości teorii Beckera, która do tej pory była uznawana za „odhumanizowaną” z powodu akcentowania czynników ekonomicznych. Sprawa, która niepokoiła uczestniczkę rozmowy, okazała się próba przenoszenia „modelu skandynawskiego na grunt polski”. Badania prowadzone przez nią wskazują na to, że coraz większa ilość ludzi odchodzi od Kościoła, od uniwersalnych wartości etycznych, od tradycyjnego modelu rodziny, zgadzając się na kohabitację [wspólne zamieszkanie - jedna z form współczesnych tzw. wolnych związków; dopisek własny] i różne związki partnerskie.

Kolejny uczestnik rozmowy poprosił profesor Frątczak o rozwinięcie użytego w referacie zwrotu „epide- 
miologia zagrożeń prokreacyjnych". Pytający poprosił także o komentarz w sprawie rosnącego w zachodniej Europie uznania dla związków małżeńskich, wśród których nie ma przełożenia na wzrostowy wskaźnik dzietności. Nadal bowiem najwyższe wskaźniki posiadają państwa skandynawskie, w których większość dzieci rodzi się z wolnych związków. Następnie pytający poprosił profesor Frątczak o ustosunkowanie się do, jego zdaniem, „przeciwstawnych dyskusji” doktora Michalskiego i doktor Ziębińskiej. Według niego prezentują oni dwie różne koncepcje wyjścia z kryzysu dzietności. Doktor Michalski koncentruje się na kwestii płacy rodzinnej, doktor Ziębińska natomiast na wspieraniu kobiet pracujących.

Następnie poruszono kwestię znaczenia zachowań i postaw mężczyzn w sprawie dzietności wśród kobiet. Zdaniem kolejnej uczestniczki dyskusji obniżenie się ilości urodzin spowodowane jest również zachowaniem mężczyzn. Decyzja o posiadaniu potomstwa jest przecież wspólną decyzją małżonków. Może się zdarzyć, że to mężczyzna nie chce posiadać potomstwa - co może być powszechne w dzisiejszej kulturze, w której obserwuje się kryzys ojcostwa. Jej zdaniem, kwestia dzietności kobiet w USA nie jest tak prosta, jak przedstawiono ją podczas prelekcji. Według badań, średnia dzietność kobiet w USA podnoszona jest głównie przez Afroamerykanki, które cieszą się często opieką socjalną państwa -wychowując dzieci samotnie, natomiast dzietność białych kobiet jest dużo niższa.

Doktor Sławomir Sowiński z Instytutu Politologii UKSW poruszył po raz kolejny kwestię „fenomenu skandynawskiego". Wyszedł od przykładu polityki prorodzinnej we Francji, polegającej na pomocy finansowej dla rodzin, która okazała się wg niego skuteczna na gruncie francuskim, ale jednak nie osiągnęła sukcesu w Niemczech. Natomiast inny model polityki prorodzinnej, z krajów skandynawskich, gdzie większy nacisk kładzie się na wspieranie aktywności zawodowej kobiet oraz powszechnie akceptuje się związki pozamałżeńskie, spowodował 
wzrost dzietności kobiet. Doktor Sowiński zasugerował jakoby wzrost dzietności spowodowany był zmianami kulturowymi. Model wolnych związków wytwarza poczucie niższej odpowiedzialności za dziecko i rodzinę. Posiadanie dziecka nie kojarzy się więc z tak dużą odpowiedzialnościa, jak w krajach południowej Europy. Drugie zagadnienie poruszone przez pracownika UKSW dotyczyło tzw. drugiej fali wzrostu demograficznego w Skandynawii. Pytający był zainteresowany możliwością wystąpienia takiej „drugiej fali wzrostu demograficznego w Polsce".

Przejmując głos, Małgorzata Kidawa z Uniwersytetu Jana Pawła II w Krakowie podziękowała za uchwycenie roli mężczyzny w decyzji o macierzyństwie. W jej opinii, w obecnych czasach rodzina przestaje być postrzegana łącznie. W zespołach tworzących programy aktywizacji ludzi zagrożonych wykluczeniem społecznym mówi się o aktywizacji chorych, niepełnosprawnych, ojców, matek, ale nie tworzy się programów dla rodzin. W ogóle termin „polityka na rzecz rodzin” staje się pojęciem z dawnej epoki. Reprezentantka UPJPII podkreśliła również oderwanie kulturowe współczesnych rodzin. Poczucie braku bezpieczeństwa wiąże się - jej zdaniem - nie tylko z bezpieczeństwem ekonomicznym, lecz również z kwestią fundamentu aksjologicznego, na którym młodzi rodzice mogliby oprzeć wychowanie dzieci.

Kolejny uczestnik dyskusji podjął kwestię niedawno zakończonego II Krajowego Kongresu Demograficznego. Podobne kongresy w krajach zachodnioeuropejskich wywołują poruszenie na szczeblach rządowych. Nie jest jednak pewne, czy „polski kongres” wywołał jakiekolwiek reakcje w polityce rodzinnej i demograficznej polskiego rządu. Z kolei, następny pytający, odnosząc się do referatu, w którym poruszono kwestię zaniku populacji białego człowieka oraz niedawno przedstawionych wyników wzrostu dzietności we Francji i Islandii, zadał pytanie o udział związków małżeńskich, związków autochtonicznych i imigracji w dynamice wspomnianego wzrostu 
dzietności. Jeśli wzrost dzietności miałby być spowodowany przez rodziny imigrantów, to należy zadać pytanie, w którym pokoleniu imigrantów następuje to zjawisko.

Po przedstawieniu pytań, profesor Frątczak podjęła próbę odpowiedzi na kilka z nich. Przede wszystkim, zdaniem prelegentki, należy wystrzegać się założenia, jakoby sposób rozwiązania problemów demograficznych, który sprawdził się w danym kraju, mógł zostać pomyślnie wprowadzony w innych. Systematycznie prowadzona we Francji, od zakończenia II wojny światowej, polityka demograficzna daje dziś efekty. Francja ma obecnie mniejsze problemy z zastępowalnością pokoleń, choć oczywiście trudności występują. Dodatkowym atutem demograficznego dynamizmu tego kraju jest napływowa ludność francuskojęzyczna z Afryki. Z kolei, model zastosowany w krajach skandynawskich czy anglosaskich również nie sprawdzi się $\mathrm{w}$ krajach takich jak Polska, Hiszpania czy Włochy. W społeczeństwach tych państw występuje tradycyjny, katolicki model rodziny rozumianej jako sakramentalny i nierozerwalny związek kobiety i mężczyzny. W krajach skandynawskich i anglosaskich nierozerwalność małżeństwa nie jest sprawą zasadnicza, nie jest traktowana tak, jak w ,krajach katolickich”. Jako przykład pani profesor podała sytuację, w której sama się znalazła. Będąc na drugim ślubie znajomej w Kościele Anglikańskim, miała okazję siedzieć przy jednym stole z byłą żoną pana młodego i jego dziećmi z poprzedniego związku. Wśród wszystkich zaproszonych jedynie ona była w pierwszym związku małżeńskim. Taka sytuacja nie jest, zdaniem profesor Frątczak, czymś niezwykłym w krajach kultury protestanckiej, natomiast jest trudna do zaakceptowania w środowiskach z kręgu kultury katolickiej. W rodzinach tworzonych w Skandynawii dziecko traktowane jest jako „pamiątka po związku”, o czym dała wyraz prelegentka w raporcie, jaki sporządziła na ten temat dla Rady Europy.

W odniesieniu do wspominanych kongresów demograficznych profesor Frątczak wyraziła rozczarowanie. 
Efekty pierwszego kongresu, w którym aktywnie uczestniczyła, pozostały jedynie deklaracjami zapisanymi na kartkach papieru. Nie miały one znaczenia w kształtowaniu polityki demograficznej rządu. Problem sformułowania sprawnej polityki demograficznej dla Polski wymaga przede wszystkim przyzwolenia politycznego i zgody ugrupowań politycznych zasiadających w Sejmie i Senacie RP. Ponadto, taka polityka musiałaby zyskać poparcie społeczne. Wzrost dzietności nie może zostać wprowadzony na drodze podobnej do wprowadzenia wieku emerytalnego. Decyzja o posiadaniu potomstwa na zawsze pozostanie indywidualną decyzją poszczególnych rodzin. Sprawę demografii Polski można jednak łagodzić poprzez stwarzanie warunków bezpieczeństwa, zapewnianie stabilnych miejsc pracy itp., co powinno zachęcać około trzymilionową populację polskich emigrantów do powrotu do ojczyzny.

Ogromnym problemem dzisiejszego świata staje się poczucie ryzyka. Obecnie, coraz częściej, zaczyna się mówić o towarzyszącym mu zjawisku napięcia pomiędzy różnymi sferami życia. Takie napięcie występuje również między karierą zawodową a rodzicielstwem. Te dwa odczucia w znacznej mierze odpowiadają za odwlekanie lub za rezygnację $\mathrm{z}$ rodzicielstwa.

Przełożenie wyników II Kongresu Demograficznego na politykę demograficzną zależy od zaangażowania rządu. Rząd jednak wydaje się dążyć w kierunku wyznaczonym przez Radę Europy, która zdecydowała się na zlikwidowanie Komitetu Demograficznego Rady Europy. Zakłada się, że Europa może zaspokoić potrzeby demograficzne poprzez migrację. Na pierwszy plan wysuwają się Chiny, które, rozwijając się w zastraszającym tempie, produkują coraz większe ilości specjalistów. Państwo Środka może "zalać" rynki Europy, tak jak zapełniło rynki afrykańskie. Dla Europy rysuje się czarna perspektywa wymarcia ludności autochtonicznej. Ratunkiem dla niej może być jedynie sprawna polityka demograficzna oparta o promocję i szacunek dla rodziny. 
Następnie profesor Frątczak odniosła się do doświadczenia wspólnej pracy z prof. Wojciechem Hanke w Łódzkim Instytucie Medycyny Pracy, podczas której zajmowano się między innymi epidemiologią zagrożeń prokreacyjnych. Prace dotyczyły zagrożeń związanych z płodnościa, bezpłodnościa, ciąża, porodem oraz pierwszym rokiem macierzyństwa. Według wyników badań profesor Parandowskiej, z którymi zgadza się prelegentka, coraz poważniejszy staje się problem bezpłodności młodych mężczyzn. Odnosząc się natomiast do teorii Beckera, pani profesor zauważyła, że jest ona tylko jedną z kilku racjonalnych teorii. Jej minusem wydaje się silne akcentowanie czynników ekonomicznych. W latach osiemdziesiątych i dziewięćdziesiątych ubiegłego wieku wprowadzono w badaniach demograficznych teorie hazardu i przeżycia. Pokładano w nich duże nadzieje. W dzisiejszych czasach teorie te nie tłumaczą wystarczająco rzeczywistości z powodu zmieniających się warunków środowiskowych. Podobnie będzie, zdaniem prelegentki, $\mathrm{z}$ teoriami obecnie tworzonymi.

Andrzej Ochocki, przejmując głos, zgodził się z opinią Ewy Frątczak na temat politycznych skutków II Kongresu Demograficznego. Drugą kwestia, jaką poruszył prelegent, była relacja między polityką demograficzną i polityką rodzinną. Zdaniem Ochockiego, termin "polityka demograficzna" bez uzupełnienia go o elementy związane z migracją międzynarodową jest anachroniczny. Natomiast istnieje ważny element polityki społecznej, zwany polityką rodzinna, który może zmieniać zachowania prokreacyjne młodych pokoleń. Co prawda, nie ma prostego przełożenia polityki skandynawskiej na grunt polski, jednak tworzenie odpowiednich warunków do realizacji aspiracji młodych kobiet i mężczyzn może jedynie polepszyć sytuację demograficzną Polski. W uboższych krajach Unii Europejskiej, do których należy Polska, należy wspierać rodziny poprzez transfer pośredni do budżetów rodzinnych - co dawać będzie większy poziom poczucia bezpieczeństwa. 
Dyskusja nr 3.

Po dwóch kolejnych częściach sympozjum zatytułowanych: Kryzys demograficzny jako wyzwanie dla Kościoła oraz Kryzys demograficzny w Polsce - rodziny wielodzietne, uczestnicy spotkania podjęli kolejną dyskusję.

$\mathrm{Na}$ początku prowadzący podkreślił rolę Kościoła w podejmowaniu działań na rzecz zwiększenia dzietności Polek. Jednak działania te, choć liczne, nie przynoszą - jak pokazuje doświadczenie - efektów. Około 95\% obywateli przez fakt przyjęcia chrztu stało się uczestnikami życia i misji Kościoła Katolickiego, którego nauczanie w sprawie posiadania potomstwa wydaje się nie mieć dla nich większego znaczenia. Kościół oficjalnie głosi pochwałę życia rodzinnego i posiadania potomstwa - o czym świadczy chociażby proces beatyfikacyjny polskiej rodziny Ulmów - podawanej nie tylko jako przykład męczeństwa, ale i wzorowej rodziny. Widać jednak, że podziw dla tak bohaterskich postaw nie rodzi naśladowców. Po przedstawieniu powyższej tezy prowadzący dyskusję poprosił o komentarz prelegentów.

Pierwsza z dyskutantów odniosła się do referatu Teresy Kapeli Kościół wobec wielodzietności (publikowanego w niniejszym opracowaniu pt: Rodziny wielodzietne w Polsce. Stwierdziła ona, iż obecnie nie tworzy się profesjonalnych opracowań poświęconych rodzinom wielodzietnym, takich jak przeprowadzane w latach osiemdziesiątych ubiegłego wieku. Dziś opracowania takie sporządzane są na potrzeby programów Europejskiego Funduszu Społecznego i nie cieszą się szczególna dokładnością (powodem jest pośpiech w ich tworzeniu i czysto utylitarna funkcja w pozyskiwaniu środków publicznych). Kolejną sprawą jest częste zmienianie ministerstw zajmujących się rodziną - od Ministerstwa Zdrowia do Ministerstwa Pracy i Opieki Społecznej. Od dłuższego czasu sprawa rodzin spychana jest w zakres odpowiedzialności samorządów terytorialnych. Obecnie istnieje ponad sześćd ziesiąt ustaw, które nakładają na samorządy 
obowiązki w stosunku do rodzin, a ustawom tym nie towarzyszy pomoc finansowa ze strony rządu. Prelegentka zaznaczyła także, iż Kościół podejmuje wiele inicjatyw na rzecz zażegnania kryzysu rodziny, łącznie z dużym nakładem środków finansowych. Środki te są jednak niewystarczające, brakuje również niekiedy organizacji i integracji wśród odpowiedzialnych za wspieranie rodzin ze strony Kościoła.

Kolejny uczestnik dyskusji wymienił trzy, jego zdaniem, najistotniejsze strefy wpływów Kościoła w relacji do rodzin i dzietności Polaków. Pierwszym z nich i podstawowym jest praca prowadzona $w$ parafiach. Drugim są wszelkie organizacje tworzone przez Kościół w celu wspierania rodzin i wychowania. Trzecią sfera jest wpływ Kościoła na decyzje podejmowane na szczeblu państwowym, zwłaszcza wpływ wywierany na rząd w celu wprowadzania korzystnych dla rodzin ustaw i rozporządzeń. Zdaniem zabierającego głos, ten ostatni element działania Kościoła jest niestety niedowartościowany i zbyt rzadko stosowany. Chrześcijanie głoszą „Ewangelię życia” - co jest celem Kościoła i jego działania oraz sensem istnienia na świecie, aby otwierać ludzkość na nowe życie w perspektywie wieczności i teraźniejszości. Tylko dlaczego, pyta uczestnik dyskusji, głos duchowych przywódców mija się z uznaniem wiernych i ma tak niską skuteczność w przemianie obecnej sytuacji świata. Jego zdaniem, winą za taką sytuację obarczyć można w znacznej mierze dzisiejszą kampanię skierowaną przeciwko Kościołowi w środkach społecznego przekazu. Przy okazji podkreślił, że warto zauważyć zgubny wpływ tychże środków na dzietność Polaków. Przeszczepianie do kultury narodu polskiego wzorców zlaicyzowanej, zsekularyzowanej i pozbawionej wartości chrześcijańskich, a często i ogólnoludzkich, Europy, nieuchronnie prowadzi do upodabniania się obywateli do bohaterów popularnych seriali i naśladowania zdemoralizowanych zachowań celebrytów.

Kolejny uczestnik rozmowy stanął w obronie Kościoła, stwierdzając, iż istnieją takie obszary funkcjonowania ro- 
dziny, w których państwo nie może być wyręczone przez jakąkolwiek inną instytucję. Zauważył on, że Kościół nie kończy się na hierarchach, lecz jest wspólnota, w której istotnie zadanie $\mathrm{w}$ przekazie myśli przypada każdemu wiernemu - nie tylko biskupom i prezbiterom. Ważny wydaje się być udział apostolatu lokalnego, złożonego głównie ze świeckich, w podejmowaniu działań na rzecz promocji rodziny i posiadania potomstwa. Natomiast wszelkie działania na płaszczyźnie politycznej, jako sfera profanum, należy się w pierwszej kolejności państwu. Kościół nie powinien stawać się ustawodawca, ale powinien zajmować stanowisko, radzić i upominać, jeśli trzeba, tak aby ustawodawca tworzył prawo, które w pierwszej kolejności nie będzie przeszkadzało rodzinom.

Zdaniem kolejnego uczestnika dyskusji, czynniki wpływające na spadający współczynnik dzietności podzielić można na dwie kategorie. Pierwszą z nich stanowią czynniki zewnętrzne dla człowieka - takimi są między innymi warunki dyktowane przez współczesną ekonomię. Druga grupa czynników, to te, które są w stosunku do człowieka wewnętrze, i właśnie na nie powinien w pierwszej kolejności zwrócić uwagę Kościół. Jest to sfera ludzkiego postrzegania świata, wizja własnej osoby i rodziny. Jako przykład skrzywienia wewnętrznej sfery człowieka, mówiący podał wypowiedź młodej kobiety, którą usłyszał osobiście. Dla młodej matki macierzyństwo kojarzyło się ze śmiercią. Nie było w niej radości z posiadania potomstwa, lecz dominującym uczuciem było uczucie wyrwania ze świata na czas ciąży i pierwszych miesięcy życia dziecka. Świata, do którego młoda matka musiała wracać powoli. Kolejnym czynnikiem wewnętrznym jest lęk, który ogarnia serce człowieka w perspektywie opieki nad dzieckiem.

Następnie głos w dyskusji jako matka wielodzietnej rodziny zabrała Małgorzata Pawlus. Stwierdziła, że Kościół to nie tylko księża, ale przede wszystkim poszczególni ludzie wierzący, to także rodziny wielodzietne, których obecność we wspólnocie jest formą świadectwa. 
Rodzinom tym potrzebne jest wsparcie od wspólnoty wierzących - takie, jakiego doświadczyła wypowiadająca się w swojej parafii - pełnego zrozumienia, szlachetności i bezinteresowności. O ile w mediach znaleźć można wypowiedzi deprecjonujące rodziny wielodzietne, o tyle w Kościele powinny znaleźć akceptację i pomoc. Przykładem takiej akceptacji są chociażby rodziny z ruchu neokatechumenalnego posiadające często więcej niż dwoje dzieci. Jednak brak uznania wielodzietności towarzyszy często środowisku najbliższemu rodzicom. W takiej sytuacji, konieczne wydaje się opracowanie nowego języka mówienia o macierzyństwie i ojcostwie w nauczaniu Kościoła, w taki sposób, aby zmienić nastawienie społeczeństwa do tych zagadnień. Posiadanie dużej rodziny w dzisiejszym świecie jest formą świadectwa wiary. Człowiek decyduje się na to, by raczej być dla innych, niż więcej mieć dla siebie. Tworzenie się grup rodzin wielodzietnych jako formy apostolstwa, jest - zdaniem mówiącej-znakiem czasu, jest to forma propagowania dobrych praktyk i wzorców pokazujących, że dziecko i rodzicielstwo są dla człowieka wartością przekraczającą egoistyczne dążenia jednostek.

Kolejny uczestnik dyskusji zgodził się z przedmówczynią. Jednym z podstawowych zadań Kościoła w dziedzinie dbania o dzietność i rodziny jest kształtowanie odpowiedniej prorodzinnej świadomości wiernych. Kształtowanie takiej świadomości powinno odbywać się za pomoca języka dostosowanego do mentalności odbiorców. Obecny język katechezy przedmałżeńskiej silnie przesycony "teologicznym zmanierowaniem" staje się nieskuteczny - co po części jest skutkiem niezrozumiałości tej formy przekazu. Należałoby więc mówić nie tylko językiem teologii, ale także językiem racjonalnym i wskazującym realne ekonomiczne i społeczne konsekwencje rezygnacji z rodziny oraz potomstwa.

Następnie jedna z uczestniczek rozmowy podzieliła się swoimi przemyśleniami na temat przyczyn omawianego kryzysu dzietności w Polsce. Zaproponowała ona, aby poruszony przez ks. dr. Tomasza Biedrzyckiego pro- 
blem braku poczucia bezpieczeństwa rozszerzyć na całe spektrum nieładu panującego w dzisiejszej kulturze, życiu publicznym i politycznym, który przekłada się na „brak wiary w perspektywy tworzenia nowego życia i rodziny". Drugą kwestią poruszoną przez dyskutantkę była moralna kwestia założenia rodziny. Nie chodzi tu jedynie o to, iż życie w nieformalnym związku, w którym łatwiej jest potraktować drugą osobę przedmiotowo, jest sprzeczne $\mathrm{z}$ zasadami moralnymi, ale samo posiadanie rodziny, macierzyństwo i ojcostwo jawią się jako powinność moralna człowieka, którą powinien on zrealizować.

Kolejna uczestniczka dyskusji zaprezentowała zdanie odbiegające od wypowiedzi poprzedników. Zdaniem mówiącej, problemem istniejącym we współczesnym Kościele jest "twardość stanowiska” polegająca na zakładaniu z góry sztywnych ram realizowania się kobiety w dzisiejszym świecie. W opinii mówiącej, Kościół nie widzi dla młodych kobiet innej roli życiowej poza macierzyństwem lub życiem zakonnym. Tymczasem bogactwo osobowe dzisiejszych kobiet popycha je do realizowania się w innych wymiarach. Następną kwestią jest sztywne stanowisko w sprawie antykoncepcji. Według dyskutantki, około 90\% kobiet żyjących w związkach nieformalnych używa środków antykoncepcyjnych i należy się im zrozumienie ze strony Kościoła. Następnie pytająca poprosiła o wskazanie przez panią Kapelę czynników, które jej zdaniem wpłynęły na demograficzny sukces Francji.

Po zakończeniu tej części dyskusji prowadząca podziękowała prelegentom za wypowiedzi i nawiązała do audycji radiowej, którą niedawno słyszała. W audycji tej pewien ksiądz zastanawiał się nad przyczynami spadku dzietności, który dotyka głównie krajów chrześcijańskich. Zdaniem prowadzącej, taka sytuacja może doprowadzić do tego, iż Kościół przestanie istnieć z powodu braku wiernych. Prowadząca zaznaczyła, iż w perspektywie teologicznej nie można mówić o czymś takim, ale w perspektywie demograficznej z pewnością można i należy to czynić. W interesie Kościoła jest więc wzrost dzietności 
wyznawców, na który powinien wpływać poprzez ewangelizację i głoszenie słowa życia.

Kolejny uczestnik spotkania zwrócił uwagę na projekt Karty Dużej Rodziny, który obecny jest jedynie w dwudziestu gminach w Polsce. Jego zdaniem, gminy nie są zainteresowane wprowadzaniem takich rozwiązań jak prezentowany projekt. Kolejną sprawą jest coraz większy polityczny sprzeciw wobec nauczania społecznego Kościoła, co przekłada się na prezentowaną w mediach wizję rodziny. Pytanie to doczekało się natychmiastowej odpowiedzi jednego z prelegentów. Ratunkiem dla takiej sytuacji może być jedynie rozwój mediów katolickich, w sposób szczególny tych adresowanych do młodych, rozwój szkolnictwa katolickiego i sprawnie prowadzona katecheza przedmałżeńska.

Następnie, pani redaktor, rozpoczynając podsumowywanie dyskusji, podkreśliła rolę Kościoła we wspomaganiu dzietności. Podkreśliła, że problemem staje się styl języka przepowiadania katechetycznego, który w dzisiejszych czasach pozostawia wiele do życzenia. Problemem jest także brak empatii niektórych kapłanów i biskupów, którzy nie potrafią lub nie chcą wczuć się w sytuację młodych małżeństw i rodzin. Powinni oni przestać stawiać się $\mathrm{w}$ roli autorytetów $\mathrm{w}$ sprawie rodzicielstwa - sami żyjąc w celibacie, a zacząć towarzyszyć rodzinom i być dla nich wsparciem duchowym i moralnym. Problemem pozostaje również katolickie poradnictwo rodzinne, które - zdaniem mówiącej - przeradza się często w katolicką antykoncepcję, a nie stawia sobie za cel budowania pozytywnej wizji rodziny i otwierania młodych małżeństw na dar potomstwa. Na czym polega zło antykoncepcji? Wtaśnie na tym polega, ̇̇e człowiek z Bożego błogosławieństwa uczynit Boże przekleństwo, przed którym trzeba się zabezpieczać. Bóg błogosławił człowiekowi, mówiąc 'bądźcie płodni, rozmnażajcie się'. Antykoncepcja, to jest właśnie traktowanie Bożego błogosławieństwa jako przekleństwo, przed którym trzeba się zabezpieczyć. Przecież nie istnieje, coś takiego jak zgodne z Ewangelia unikanie Bożego błogosławieństwa - zdaniem prelegentki. 
Następnie głos zabrała prowadząca dyskusję, zaznaczając, iż centralnym punktem wypowiedzi pozostawał Kościół. Zdaniem prowadzącej, występuje dziś błędne rozumienie tego słowa. Coraz częściej odczytuje się je jako pewną instytucję pożytku publicznego (co dało się odczuć w wypowiedzi K. Lewandowskiego), a zaprzestaje się myśleć o Kościele „przez duże K” - czyli o wspólnocie wiary, wspólnocie Jezusa Chrystusa. Takie rozmycie znaczenia słowa Kościół zaobserwować można również wśród duchownych, u których język teologiczny staje się „demagogicznym kaznodziejstwem”. W kazaniach coraz częściej dominują kwestie ogólnoludzkie (łącznie z politycznymi), a zapomina się o przekazywaniu kerygmatu wiary chrześcijańskiej.

Następnie rozpoczął się blok odpowiedzi zaproszonych specjalistów. Pani profesor Frątczak, odnosząc się do sprawy demograficznego sukcesu Francji, zauważyła, iż kraj ten, choć zlaicyzowany, w polityce rodzinnej wprowadził większość rozwiązań proponowanych przez Kościół katolicki. Francja to jedyny kraj w Europie, którego system podatkowy uwzględnia każdą osobę będącą na utrzymaniu rodziny. System pracy zawodowej został skorelowany z systemem edukacji i nie do pomyślenia jest, aby rodzic pracował w momencie, gdy jego dziecko kończy lekcje w szkole. Pomimo laicyzacji społeczeństwa, silną rolę w tworzeniu polityki rodzinnej odgrywają stowarzyszenia katolickie zrzeszające wiele rodzin. Istnieje także wiele innych praktycznych rozwiązań, które w znacznym stopniu ułatwiają funkcjonowanie rodzin. Całkowicie inna sytuacja ma miejsce w Polsce. Jesteśmy jedynym krajem Europy, w którym macierzyństwo nie jest otoczone pełną opieką. W Polsce opieką otoczone zostają jedynie te matki, które były zatrudnione przed urodzeniem dziecka. W efekcie około 50\% młodych matek pozostaje bez opieki państwa.

Kolejna z prelegentek, odnosząc się do dokumentu $O b$ raz rodziny polskiej jako instytucji społecznej w świetle badan empirycznych (2011-2012) - będącego wynikiem omówie- 
nia ankiet przeprowadzonych w czterdziestu jeden diecezjach - zaznaczyła, iż nauka katolicka na temat rodzicielstwa i rodziny jest dość dobrze znana polskim wiernych, jednak wiedza ta nie przekłada się na praktykę życia codziennego. Problem leży między innymi w mentalności ludzi, którzy stawiają rodziny wielodzietne na równi z ubogimi i patologicznymi. Nie raz słyszymy z ambony: „Przeprowadzamy zbiórkę na rzecz dzieci z rodzin ubogich, patologicznych i wielodzietnych". Tego typu zwroty powodują społeczne naznaczenie, stygmatyzację dużych rodzin. Kolejnym problemem, zdaniem prelegentki, jest próba sztucznego podtrzymywania kompromisów z władzą. Kościół nie staje w obronie rodziny, aby nie naruszać wypracowanego kompromisu. Tak stało się, zdaniem mówiącej, ze sprawą zamknięcia czternastu ośrodków adopcyjno-opiekuńczych, które zajmowały się blisko dwudziestoma tysiącami dzieci. W tej sytuacji potrzebne było jasne stanowisko Kościoła i publiczne przedstawienie katolickiej nauki społecznej na ten temat.

Ostatni, w tej części dyskusji, zabrał głos ks. dr Józef Młyński. Zaznaczył on, że towarzyszenie Kościoła rodzinom wielodzietnym rozumiane jest często (w gronie duchownych również) jako posługa sakramentalna. Tymczasem powinno ono jedynie brać początek z tejże posługi i rozszerzać się na inne sfery życia rodzin. Kapłan nie powinien jedynie spotykać się z rodziną w kościele, ale powinien być uczestnikiem procesu wychowania młodego pokolenia - czego przykładem mogą być zgromadzenia zakonne zajmujące się wspieraniem rodzin i wychowaniem dzieci i młodzieży.

Powyższa dyskusja ukazała aktualność problematyki rodzinno-wychowawczej, rolę i odpowiedzialność za pozytywną promocję małżeństw i rodzin przez pojedyncze osoby. Wskazała także na instytucje kościelne i państwowe, ich rolę i znaczenie, ale przede wszystkich podkreśliła wielką troskę o ochronę i wspieranie rodzin wielodzietnych, uznając w tym m.in. realną szansę na poprawienie sytuacji demograficznej w Polsce. 


\section{Bożena Pietras}

Przewodnicząca Koła Lubelskiego ZDR „Trzy Plus”

\section{Dom, rodzina - tu wszystko sie zaczyna. Sprawozdanie z II Ogólnopolskiego Zjaz- du Dużych Rodzin w Lublinie w dniach 20-22 czerwca 2014 r.}

\section{Związek Dużych Rodzin „Trzy Plus”}

Związek Dużych Rodzin „Trzy Plus” jest stowarzyszeniem zrzeszającym małżeństwa z trojgiem lub większą liczbą dzieci. Wśród celów tej organizacji znajdują się między innymi: poprawa warunków bytowych i społecznych takich rodzin, kształtowanie ich pozytywnego wizerunku oraz reprezentowanie interesów tej grupy społecznej wobec władz lokalnych i państwowych. W miarę, jak struktury związku rozwijały się, a członków stowarzyszenia przybywało, zarząd Związku Dużych Rodzin „Trzy Plus” zdecydował się na zorganizowanie zjazdu wielodzietnych rodzin. Zjazd ten jest ogólnopolskim spotkaniem dużych rodzin. Celem organizowanego trzydniowego zjazdu jest integracja środowiska rodzin wielodzietnych oraz promocja wartości rodzinnych.

Pierwszy Ogólnopolski Zjazd Dużych Rodzin odbył się w Grodzisku Mazowieckim w czerwcu 2013 roku. Wydarzenie to zostało bardzo entuzjastyczne przyjęte przez uczestników, co spowodowało, że na stałe zagościło w agendzie przyszłych działań związku. Wśród zasad dotyczących organizacji zjazdu było zastrzeżenie, że może się on odbywać w mieście przyjaznym rodzinie, ale także tam, gdzie istnieje dobrze zorganizowane i aktywne środowisko ZDR „Trzy Plus”. Po długich dyskusjach zdecydowano, że to Lublin jest idealnym miejscem spełniającym te kryteria i właśnie tam będzie kontynuowana ta tradycja. 


\section{Przygotowania do zjazdu w Lublinie}

Miasto Lublin i lubelskie koło ZDR „Trzy Plus” rozpoczęły wspólne przygotowania do drugiego zjazdu w Lublinie już w grudniu 2013 roku. Podmioty podzieliły się zadaniami między sobą. Władze miasta były odpowiedzialne za wynajęcie hali Targów Lublin jako miejsca zjazdu, zapewnienie wyżywienia rodzinom, organizację zajęć dla dzieci i młodzieży oraz zapewnienie uczestnikom bezpieczeństwa w trakcie imprezy. Koło Związku Dużych Rodzin „Trzy Plus” w Lublinie zobowiązało się do przeprowadzenia naboru uczestników, zapewnienia noclegów dla rodzin, organizacji warsztatów dla rodziców oraz integracji rodzin w dniu przyjazdu, a także przygotowania mszy polowej. Miasto Lublin i ZDR ,Trzy Plus" wspólnie ustaliły program zjazdu, promowały go w mediach oraz pozyskiwały sponsorów potrzebnych do realizacji zamierzonych przedsięwzięć.

Początkowo, pomimo ogłoszeń z prośbą o pomoc w lubelskich parafiach, dużą trudność sprawiało poszukiwanie noclegów. Związkowi Dużych Rodzin zależało na umieszczeniu uczestników zjazdu w lubelskich rodzinach, aby mieszkańcy Lublina doświadczyli, jaką wartością jest duża rodzina. Dodatkowo członkowie związku chcieli pokazać, że wielodzietność to nie patologia, z czym często błędnie jest kojarzona. Dzięki takiemu ulokowaniu rodzin nawiązały się przyjaźnie i nastąpiła wymiana cennych doświadczeń, a przede wszystkim przyjezdne rodziny doznały serdecznej gościnności i życzliwości od mieszkańców Lublina. Nie obyło się bez pomocy instytucji publicznych - dwa samorządy z miejscowości, z których przyjechały rodziny, podjęły się zorganizowania autokarów potrzebnych do przewozu osób w trakcie zjazdu. Caritas Archidiecezji Lubelskiej udostępniła swój dom rekolekcyjny na nocleg dla części osób. Pozostali uczestnicy mieszkali przez ten czas w gościnnych domach lubelskich rodzin. Wszystko było dopracowane $\mathrm{i}$ „zapięte na ostatni guzik”. 


\section{Honorowy patronat}

Organizatorom zależało na patronacie nad wydarzeniem Kościoła Katolickiego - wspólnie udali się do Księdza Arcybiskupa Stanisława Budzika z zaproszeniem, a także napisali list do Ojca Świętego Franciszka z prośbą o błogosławieństwo dla organizatorów zjazdu, uczestników i rodzin ich przyjmujących do swoich domów. Obie te inicjatywy spotkały się z pozytywną reakcją i zakończyły się powodzeniem. Odpowiedź Ojca Świętego Franciszka została odczytana w czasie inauguracji zjazdu przez arcybiskupa prof. dr. hab. Stanisława Budzika. II Ogólnopolski Zjazd Dużych Rodzin został także objęty Honorowym Patronatem Prezydenta Rzeczypospolitej Polskiej Bronisława Komorowskiego oraz Małżonki Prezydenta RP Anny Komorowskiej. Para Prezydencka osobiście przybyła na otwarcie zjazdu 20 czerwca 2014 roku i odebrała z rąk pani prezes ZDR „Trzy Plus" - Joanny Krupskiej - statuetkę Przyjaciela Dużej Rodziny. Takie wyróżnienie otrzymał również Minister Pracy i Polityki Społecznej - Władysław Kosiniak-Kamysz - za zaangażowanie w pracę nad wprowadzeniem ogólnopolskiej Karty Dużej Rodziny.

\section{Przebieg II Ogólnopolskiego Zjazdu Dużych Rodzin}

Po długich przygotowaniach i wielu wysiłkach podejmowanych przez organizatorów udało się doprowadzić do realizacji zjazdu. Na powodzenie zjazdu wpłynęło wiele znaczących szczegółów. Od początku zjazdu w hali Targów Lublin, gdzie odbywała się główna część zjazdu, funkcjonował kącik dla malucha z zabawkami, pufami, przewijakami, gdzie mogła się udać każda mama z małym dzieckiem. Ten pomysł bardzo się sprawdził i podobał całym rodzinom. Posiłki w czasie zjazdu spożywano przy dużych, okrągłych, pięknie nakrytych stołach. Dzięki temu wszyscy czuli się rodzinnie i świątecznie. 
Wieczorem pierwszego dnia zjazdu przewidziana była wspólna zabawa i integracja rodzin. Wystąpił zespół Orkiestra Świętego Mikołaja z Lublina. Przy wtórze muzyki dzieci tańczyły z rodzicami, a zabawy animacyjne prowadził wodzirej.

Drugi dzień zjazdu był podzielony na dwa bloki zajęć przedpołudniowych i popołudniowych dla dzieci, młodzieży i rodziców. Dla małych dzieci odbywały się zajęcia i przedstawienia teatralne $\mathrm{w}$ przedszkolu i żłobku. Starsze dzieci i młodzież brały udział w zajęciach sportowych, spływie kajakowym, animacjach integracyjno-edukacyjnych „Legendy o Sobótce”, zajęciach plastycznych i muzycznych. Zwiedzanie Zamku Lubelskiego połączone było z warsztatami drukarskimi, a zwiedzanie Skansenu Wsi Lubelskiej z warsztatami kowalskimi. Grupa uczestnicząca w tych działaniach liczyła aż około 900 dzieci i młodzieży. W tym samym czasie rodzice mieli możliwość wzięcia udziału w panelu ekonomicznym Bon opiekuńczo-wychowawczy jako element polityki rodzinnej przygotowanym przez zespół ekspertów ZDR „Trzy Plus”. Bon jest propozycją naszego stowarzyszenia, aby to rodzice sami decydowali, czy pieniądze przeznaczą na żłobek, czy wybiorą pozostanie z dzieckiem w domu. Panel ekonomiczny okazał się być ważnym elementem podejmowanych działań ZDR „Trzy Plus” na rzecz zmian w polityce rodzinnej.

Inną propozycją były oblegane warsztaty Gra Małżeńska, w czasie których można było uzyskać odpowiedź na nurtujące pytania często zadawane sobie przez współmałżonków. Jak się „dogadać” w małżeństwie, o „kłótniach o nic". O czym myślą kobiety, a czego pragną mężczyźni, czyli o komunikacji w małżeństwie. Spotkanie, w trakcie którego próbowano odpowiedzieć sobie na powyższe i inne podobne pytania, poprowadzili Agnieszka i Jakub Kołodziejowie - pomysłodawcy i redaktorzy czasopisma dla małżeństw "Zbliżenia". Następne spotkanie z rodzicami animowali dr Anna i dr Ireneusz Siudemowie. Tematem poprowadzonego przez nich szkolenia była 
Profilaktyka ryzykownych zachowań młodzieży. Prowadzący przedstawiali możliwość działań profilaktycznych $\mathrm{w}$ rodzinie, w kontaktach $\mathrm{w}$ cyberprzestrzeni oraz $\mathrm{z}$ mediami. Rozmowy dotyczyły różnych zagrożeń, takich jak uzależnienia, stosowanie przemocy oraz zbyt wczesna inicjacja seksualna. Dobre wychowanie w rodzinie, to kolejne warsztaty zaproponowane rodzicom w trakcie Zjazdu Dużych Rodzin w Lublinie. Poprowadził je Wacław Czakon - prezes fundacji "Szczęśliwe Dzieciństwo”. W trakcie spotkania uczestnicy mieli szanse zdobyć umiejętności budowania strategii wychowawczych, komunikacji pomiędzy rodzicami a dziećmi. Wzmacniały pozycję rodziców i aktywizowały ich do działań w momencie wystąpienia problemów wychowawczych. Ostatnią propozycją czynnego spotkania dla rodziców były warsztaty Jak dogadać się z nastolatkiem?, moderowane przez dr Elżbietę Trubiłowicz. Pozwoliły one poznać odpowiedź między innymi na pytania: jak reagować w sytuacji buntu nastolatka?, czy odróżniamy kaprys od potrzeby?, kto ma kłopoty w rozmowach na trudne tematy: rodzice czy nastolatek?, jak podchodzić do trudnych tematów?, jakie są lęki współczesnych rodziców?

Wszystkie opisane powyżej spotkania cieszyły się ogromną popularnością i miały wymierne korzyści. Dzięki nim rodzice mogli wymienić się doświadczeniami, zobaczyli, że inni zmagają się z podobnymi problemami. Jak wynikało z relacji samych zainteresowanych, uświadomienie sobie tego faktu okazało się mieć działanie uspokajające, dające nadzieję, a także bardzo potrzebne, zwłaszcza młodym rodzicom. Atrakcje popołudniowe były skierowane do całych rodzin, miedzy innymi odbył się seans filmowy, zwiedzanie zabytków Lublina oraz zajęcia sportowe. W Hali Targów Lublin miał miejsce również kolejny koncert - wystąpił Joszko Broda z dziećmi, który ku uciesze wszystkich zebranych wykonał hymn zjazdu „Pełna chata” i wiele innych utworów. Na koncert, oprócz uczestników całego zjazdu, zostały również zaproszone rodziny z miasta. $W$ tym samym czasie odbywał 
się kiermasz rękodzieła oraz była możliwość obejrzenia wystawy. Rodziny mogły także skorzystać z porad lekarskich i edukacyjnych. Wieczorem odbyło się zebranie członków ZDR „Trzy Plus”, w trakcie którego omawiano sprawy organizacyjne stowarzyszenia. Po spotkaniu uczestnicy zjazdu zostali zaproszeni do Skansenu - Muzeum Wsi Lubelskiej na uroczystości związane z Nocą Świętojańską.

\section{Zakończenie zjazdu}

Uwieńczeniem całego zjazdu była Eucharystia, którą celebrował biskup Ryszard Karpiński. Po Mszy Świętej został ponownie odczytany list od Ojca Świętego Franciszka, owacyjnie przyjęty przez rodziny uczestniczące w zjeździe. Na zakończenie wystąpił dziecięcy chór „Kasjopea" z Oratorium o mieście Lublinie. Po wspólnym posiłku rodziny zaczęły się rozjeżdżać do swoich domów, niektóre $\mathrm{z}$ nich miały przed sobą długą drogę.

Dla wielu osób Ogólnopolski Zjazd Dużych Rodzin był pierwszą możliwością wspólnego wyjazdu z całą rodziną. Żegnając się, wszyscy zgodnie podkreślali znaczenie zjazdu i dziękowali za życzliwość i gościnność, z jakimi zostali w Lublinie przyjęci. Rodziny wyjeżdżały z Lublina wzmocnione, docenione i utwierdzone w drodze, jaką wybrały. To wydarzenie idealnie wpisało się w obchodzony „Rok Rodziny” ogłoszony przez Organizację Narodów Zjednoczonych oraz w październikowy Synod poświęcony rodzinie w Watykanie. Zjazd był przede wszystkim miejscem spotkania dużych rodzin z całej Polski w spokojnej i świątecznej atmosferze. W czasie organizacji tego zjazdu ZDR „Trzy Plus” przyświecało motto, że rodziny są najważniejsze. Po zjeździe organizatorzy dostali wiele e-maili ze zdjęciami, a także podziękowania wraz z potwierdzeniem, że taka formuła zjazdu się sprawdziła. Przede wszystkim podkreślano potrzebę warsztatów. Kontynuacją wydarzeń zjazdowych jest projekt „Rodzinni” - cykliczny program nagrywany w telewizji „Nieza- 
leżny Lublin" dotyczący problematyki poruszonej w trakcie warsztatów, które miały miejsce na II Ogólnopolskim Zjeździe Dużych Rodzin.

\section{Home, family - here it all begins}

\section{Report of the 2nd National Congress of Large Families in Lublin 20th-22nd June 2014}

\section{Summary}

Nowadays it is necessary to understand the problems, as well as the strengths of large families. The answer for this topic was the $2^{\text {nd }}$ National Congress of Large Families which took place in Lublin between $20^{\text {th }}$ and $22^{\text {nd }}$ of June 2014. An report of this event shows that it was difficult and laborious project but it was worth all the effort. Families' reactions were overwhelmingly positive, indicating a sense of home, family while the congress. The atmosphere was vibrant and families' members were full of energy. It is curious that large families, which for so long have been marginalized by the dominant society, have precisely the enthusiasm and the good attitude to face all tough problems. During congress there were many activities organized and it all ended with a great success. 

Ks. Mariusz Chamarczuk SDB

WSD TS w Lądzie

Ks. Dominik Chmielewski SDB

Duszpasterz Akademicki UKSW

\section{Świadectwa osób dojrzewających do świado- mego macierzyństwa i ojcostwa we wspólno- cie Nazaret przy duszpasterstwie akademic- kim UKSW}

\section{1. Świadectwo o roli jaką odegrała wspólnota Nazaret} $w \dot{z} y c i u .$.

Powstanie wspólnoty Nazaret było owocem wielu wysłuchanych modlitw, w tym naszej, gdyż poszukiwaliśmy takiej wspólnoty około 2 lata... wspólnoty ludzi o podobnym systemie wartości, gdzie Bóg jest na pierwszym miejscu, i mających wspólne cele, jakimi są: chrześcijańska formacja małżonków w komunii z Kościołem i wychowanie dzieci w wierze. Owocami tej 1,5 rocznej formacji jest otwarcie na współmałżonka i jego lepsze zrozumienie poprzez szczególnie podkreślenie roli mężczyzny i ojca oraz roli kobiety, matki w małżeństwie i w rodzinie. Jednym z narzędzi służącym budowaniu takich postaw jest dialog małżeński czy wspólna modlitwa małżeńska, wspólny różaniec czy też Liturgia Domowa - wspólne cotygodniowe rodzinne czytanie i rozważanie Słowa Bożego, modlitwa i Błogosławieństwo. Tego wszystkiego uczymy się właśnie w naszej wspólnocie, dzięki czemu nasze małżeństwo jest nieustannie uzdrawiane $\mathrm{z}$ wielu zranień. Poprawiają się nasze wzajemne relacje, wzrasta szacunek do współmałżonka, co przekłada się bezpośrednio na relację naszą do dzieci, a co za tym idzie na uzdrawianie całej rodziny. 
Wspólnota Nazaret to również otwarcie na drugiego człowieka poprzez dzielenie się świadectwem życia, doświadczeniem wiary, małżeństwa, wychowania dzieci. Zawiązują się między nami przyjaźnie, spotykamy się również poza oficjalnym harmonogramem spotkań. Nasze dzieci również nawiązują między sobą głębsze relacje, co daje im wzmocnienie $\mathrm{w}$ zderzeniu $\mathrm{z}$ często brutalną rzeczywistością szkolną, gdzie w obecnych czasach dzieciaki, które regularnie chodzą do kościoła i spowiadają się, należą do mniejszości (np. w klasie naszego syna tylko 4 dzieci praktykuje swoją wiarę). To wszystko daje odwagę do życia w zgodzie z Ewangelią.

Nasza formacja jako świadomych chrześcijan zaczęła się jeszcze przed powstaniem wspólnoty Nazaret i przebiegała początkowo we wspólnocie Jeshua. Tam otwarliśmy się na życie, mimo iż wcześniej nie wyobrażaliśmy sobie, że moglibyśmy mieć więcej dzieci. Obecnie mamy ich troje. W Nazarecie zdobyliśmy podstawy naturalnych metod planowania rodziny. Nieraz słyszymy wobec NPR takie ośmieszające metodę określenia jak np. watykańska ruletka. Dzięki temu, że formujemy się wśród małżeństw, które te metody również z powodzeniem stosuja, możemy podjacć dialog z tymi, którzy wyśmiewają te metody.

\section{2. Świadectwo o życiu rodzinnym w kontekście otwar- cia na życie, o formacji w Nazarecie, o odwadze do życia wartościami Ewangelii.}

Z Pawłem poznaliśmy się 11 lat temu, krocząc w pielgrzymce do Matki Bożej Częstochowskiej. Od razu zwróciliśmy na siebie uwagę i po pielgrzymce zaczęliśmy się spotykać. Już pierwsze dwa lata były dla nas sprawdzianem, gdyż mieszkaliśmy o 7 godzin jazdy pociaggiem od siebie. Ja w Chełmie, gdzie chodziłam do liceum, Paweł na studiach w Krakowie. Po 3 latach znajomości zamieszkaliśmy w Warszawie, a po 4 pobraliśmy się. Nie planowaliśmy od razu powiększać rodziny. Wynajmowaliśmy 
małą kawalerkę, ja co prawda pracowałam, ale bez umowy. Paweł rozpoczynał pracę w swoim zawodzie. Jednak nie zamykaliśmy się zupełnie na poczęcie. Stosowaliśmy NPR, ale było to bardziej z mojej inicjatywy. Paweł nie był do końca przekonany do tych metod. Nie mieliśmy wtedy relacji z Panem Bogiem, jednak ważne były dla nas kwestie wiary, nauka Kościoła, także w sferze bliskości małżeńskiej i otwarcia na życie. Mimo obaw, chcieliśmy żyć zgodnie z nauką Ewangelii. Oddaliśmy tę sprawę Panu Bogu, który sam wszystko zorganizował.

Pół roku później dowiedzieliśmy się, że jestem w ciąży. Na początku byliśmy zaskoczeni, ale byliśmy wdzięczni za to małe życie, które w jednym momencie przewartościowało naszą codzienność. Musieliśmy zapewnić naszej istotce to, co najlepsze i odpowiedzialnie zaplanować najbliższy czas. Początki ciąży nie były dla nas łatwe. Dzień, w którym powiedziałam w pracy, że jestem w ciąży, był ostatnim dniem mojej pracy. Zostałam bez dochodu, z trudnościami w znalezieniu odpowiedniego lekarza, gdyż pierwszy specjalista zaproponował nam możliwość usunięcia ciąży w razie jakichkolwiek problemów (byłam od początku ciąży na podtrzymujących lekach, więc pan doktor zalecił zrobienie prenatalnych badań, żeby sprawdzić, czy dziecko rozwija się prawidłowo, jeśli nie, to jest przecież aborcja!; kiedy na badanie się nie zgodziliśmy, usłyszeliśmy, że jesteśmy nieodpowiedzialnymi rodzicami). Jednak nie wątpiliśmy w Opatrzność Bożą i opiekę Pana Boga nad nami. Udało się znaleźć odpowiedniego lekarza, pod koniec ciąży wynajęliśmy większe mieszkanie w tej samej cenie, a mąż dostał podwyżkę w pracy.

Po roku wzięliśmy kredyt i przeprowadziliśmy się do nowego mieszkania. Przyszedł czas, kiedy zapragnęłam kolejnego dziecka. Paweł nie podzielał do końca mojego pragnienia, jednak pół roku później dowiedzieliśmy się o kolejnej ciąży. Pojawiła się obawa przed realiami życia codziennego, ja dwa miesiące wcześniej zaczęłam pracę, kredyt do spłacenia, małe dziecko w domu, które potrzebuje mamy dla siebie, a ja w ciąży, ale bardzo ucieszyli- 
śmy się z tej wiadomości. Wiedzieliśmy, że Pan Bóg zatroszczy się o nas. Obdarował nas dwiema wspaniałymi córkami, które bardzo kochamy i staramy się im dać od siebie wszystko, co najlepsze.

Wiedzieliśmy zawsze, że Pan Bóg jest z nami i troszczy się o nas, mimo, że my nie zawsze byliśmy blisko Niego. Szukaliśmy Go, ale tak po swojemu. Modliliśmy się rano i wieczorem, chodziliśmy do kościoła w niedziele, ale czuliśmy, że to jest za mało.

Trafiliśmy na rekolekcje dla małżeństw. Tam Pan Bóg zaczął otwierać nasze serca i oczy. Zaczęliśmy widzieć sytuacje w naszym życiu, w których był obecny Pan Bóg. Zaczęliśmy widzieć, że On jest blisko nas, jeśli tylko zaprosimy Go do naszego domu, do naszego małżeństwa, do naszego życia. Pragnęliśmy być w jakiejś kościelnej wspólnocie. Krążyliśmy wokół Domowego Kościoła, żeby należeć do Wspólnoty razem z dziećmi, ale teraz wiemy, że Pan Bóg miał dla nas inne plany. Chwilę później dołączyliśmy do Wspólnoty Jeshua. Kiedy na spotkaniu ksiądz powiedział, że powstaje nowy odłam Wspólnoty - Wspólnota Nazaret dla małżeństw i rodzin z dziećmi, byliśmy zachwyceni. To była możliwość, aby rozwijać się razem z innymi małżeństwami, aby dzieci miały możliwość uczęszczać tam razem z nami.

Wspólnota Nazaret spotyka się już ponad rok. Zaczęliśmy w gronie kilku rodzin, teraz grupa powiększyła się do prawie 30 rodzin. Rodziny potrzebują i szukają możliwości wspólnotowej formacji. Każdy z nas ma swoją historię, problemy, ale patrząc na siebie, dzieląc się swoimi doświadczeniami z zakresu duchowości, małżeństwa, rodzicielstwa razem wzrastamy, staramy się być lepszymi małżonkami i rodzicami. Nasze dzieci przebywają ze sobą, modlą się razem $\mathrm{z}$ nami. W ten sposób staramy się w nich zaszczepić wartości życia chrześcijańskiego. Bycie we Wspólnocie Nazaret pozwala nam się spotykać z ludźmi o podobnych wartościach, nasze dzieci mają znajomych, którym Pan Bóg jest bliski. Mogą one formować się, patrząc na przykłady innych rodzin, które chcą wzrastać 
w wierze. W dzisiejszych czasach bardzo trudno jest być chrześcijaninem i potrafić bronić swoich poglądów, kiedy wszyscy wokoło są innego zdania. Dlatego, należąc do Wspólnoty dla rodzin, chcieliśmy pokazać naszym dzieciom, że są dorośli oraz dzieci, którzy też kochają Pana Boga i modlą się. Wierzymy, że dzięki temu będą kiedyś potrafiły przeciwstawić się światu, który będzie im wmawiał co innego.

Zaczęliśmy praktykować w naszym domu modlitwę rodzinną. Najpierw sami z mężem zaczynaliśmy odmawiać Różaniec lub Koronkę do Bożego Miłosierdzia. Na początku nasze dzieci szalały wokół nas, wchodząc nam na plecy, próbując odwrócić naszą uwagę. Jednak nie zmuszaliśmy ich, aby grzecznie klęczały przy nas. Po kilku razach nasze dziewczynki zaczęły chociaż na chwile dołączać do nas, a potem chciały prowadzić te modlitwy. Oczywiście nie za każdym razem, ale przez to, że obserwują rodziców klęczących przed Kimś większym, wiedza, że w naszej rodzinie Pan Bóg jest najważniejszy. Ciągle powtarzamy im też, że one są nam dane w prezencie od Pana Boga i to do Niego należą. My jesteśmy tylko wdzięczni za to, że Pan Bóg pozwolił nam je wychować i w swojej ułomności staramy się to zrobić jak najlepiej. Wiemy, że bycie we Wspólnocie bardzo nam to ułatwia.

W naszej Wspólnocie praktykowana jest także Liturgia Domowa. Jest to wyjątkowa modlitwa prowadzona przez głowę rodziny, przez męża, ojca, który jest (w pewnym sensie) kapłanem naszego domu. Gromadząc się razem, całą rodziną trzymając się za ręce, modlimy się wspólnie do Ducha Świętego, mąż czyta fragment niedzielnej Ewangelii i wspólnie ją rozważamy. Mamy możliwość razem usiąść i podzielić się Słowem. Prośby, które kierujemy później do Pana Boga pozwalają nam się otworzyć, zobaczyć wspólne pragnienia i potrzeby. Kolejnym etapem tej modlitwy jest błogosławieństwo udzielane przede wszystkim przez ojca i męża. On nakłada swoje ręce na nasze głowy i ochrania naszą rodzinę przez Boże Błogosławieństwo. Ta modlitwa daje mi niesamowite poczucie bezpieczeństwa. 
W życiu nie zawsze odczuwamy, że Pan Bóg jest blisko, i czasami ciężko nam rozumieć sytuacje, których doświadczamy, ale z perspektywy czasu widzimy, że nawet najtrudniejsze problemy oddane w modlitwie Panu Bogu przynoszą dobre owoce. Najważniejsze jest, aby całkowicie powierzać się Panu Bogu, oddać całe życie w Jego opiekę z pełnym zaufaniem, że cokolwiek nas spotka, jest dla nas dobre. Oczywiście, nie zawsze robimy to z łatwością, ale na Nim jeszcze nigdy się nie zawiedliśmy.

Marta i Pawet Rozwoda

\section{3. Świadectwo o otwarciu się na Boga i jego wpływie na życie rodzinne}

\section{Drodzy!}

Nasze wejście do wspólnoty Nazaret niesamowicie pogłębiło nasze relacje z Panem Bogiem i między nami w rodzinie. Bóg wszedł do naszego życia i poukładał wszystko na nowo - wyznaczył priorytety, codziennie mówi do nas przez swoje Słowo i dzięki temu wyznacza kierunek, w którym podążamy. To niesamowite, jak otwarcie się na Boga zmienia podejście do otaczającego świata. Kiedyś zabieganie, ciagły stres o przyszłość, brak czasu dla najbliższych, praca na pierwszym miejscu, ciągłe wypalanie się, zmęczenie, frustracja, zniechęcenie, brak sensu...

Kiedy powierzyliśmy to wszystko Bogu, to nagle cały ten życiowy chaos, ten bałagan, zaczynał się porządkować, układać, tworzyć jakiś spójny obraz, poczucie sensu... Dzisiaj, po roku naszej obecności we wspólnotowych spotkaniach, jesteśmy w zupełnie innym miejscu. Spokój, zaufanie, głęboka wiara w to, że Bóg realnie działa w naszym życiu - nawet, jeżeli coś nie idzie po naszej myśli, to i tak potem okazuje się, że nie ma tego złego, co by na dobre nie wyszło. Kiedyś było to dla mnie tylko zwykłe porzekadło ludowe - dziś jest głęboką wiarą w to, że Bóg z najbardziej beznadziejnych sytuacji potrafi wyprowadzić dobro...

I tyle od nas... 


\section{4. Świadectwo o nawróceniu i nadziei w kontekście daru życia}

\section{Letni katolik}

Jesteśmy małżeństwem od 15 lat. Nasza droga nawrócenia rozpoczęła się po narodzeniu drugiej córki, tj. ok 5 lat temu. Wcześniej byłem tzw. letnim katolikiem. Chodziłem do kościoła, ale raczej z tradycji aniżeli z wiary czy potrzeby serca. Bardziej ze strachu przed karą i ewentualnym piekłem (jeżeli w ogóle miało by istnieć), aniżeli z miłości czy pragnienia spotkania z Bogiem. I tak żyło nam się całkiem dobrze, nie brakowało nam niczego, była praca, mieszkanie, znajomi, dzieci - czegóż chcieć więcej? Niektórzy nie mieli nawet połowy tego, co my - byliśmy szczęściarzami. Nigdy nie prosiłem Boga o pomoc, bo przecież sami sobie damy radę. Skończyliśmy dobre szkoły, mamy dobrą pracę, robimy karierę, mamy dużo znajomych, jesteśmy zaradni.

\section{Małżeństwo}

Jednak coś było nie tak w naszym małżeństwie. Zamiast radości był smutek. Zamiast zbliżania się do siebie było oddalenie. Kłótnie, wyrzuty, wzajemne obwiniane się. Nie pomagało robienie kariery, zakupy, nowe mieszkanie, podróże itd. Wszystko to było na chwilę, a później znowu to samo. Nie dawałem żonie poczucia bliskości, miłości, ciepła, opieki, zainteresowania, partnerstwa itd. Doprowadziłem do tego, że zaczęliśmy myśleć o rozwodzie. Nawet łatwo było go przeprowadzić, mieliśmy przecież dwa mieszkania - każde z nas weźmie po jednym i nikt nie powinien czuć krzywdy.

\section{Nawrócenie}

Przez tzw. „przypadek” (choć dziś wiem, że przypadków nie ma, gdyż jest to reżyseria Boża) trafiliśmy na 
weekendowe rekolekcje. I od tego czasu wszystko zaczęło się zmieniać.

Do tej pory to ja byłem panem sytuacji. Chodziłem do pracy, zarabiałem, budowałem majątek, opiekowałem się dziećmi. I chociaż w pracy szło mi świetnie, to pozostałe aspekty życia, w tym nasze małżeństwo, były w coraz gorszym stanie. Podczas rekolekcji Pan otworzył mi oczy. Pokazał, gdzie jestem i dokąd zmierzam - i że jeśli jestem taki "odpowiedzialny” za rodzinę, za jakiego się uważałem - to $\mathrm{w}$ takim razie warto $\mathrm{w}$ końcu wziąć odpowiedzialność za rodzinę, bo obecne moje samodzielne starania prowadzą raczej do nieuchronnej klęski, rozkładu rodziny i małżeństwa. Był taki moment całkowitego oddania się, zawierzenia. Miałem z tym ogromny problem, nie chciałem oddać wszystkiego, co mam. Przecież to wszystko było moje, tak ciężko przeze mnie zapracowane. Moja praca, moja żona, moje dzieci, mój majątek i wszystkie dobra, które zgromadziłem też są moje. Dlaczego mam to oddawać???

Z chwila, kiedy szczerze przyznałem się przed samym sobą, że nie jestem w stanie sam wszystkiego załatwić, że potrzebna jest mi pomoc, kogoś naprawdę Wszechmogącego, kiedy otworzyłem się na pomoc i na słowo Boga - to wtedy wszystko zaczęło się zmieniać. Pan otrzymał z powrotem wszystko to, co do Niego od samego początku należało. I zaczęły się cuda.

\section{Obecność}

Bóg zaczął zmieniać nasze życie. Nawet nieproszony, sam wiedział, co jest dla nas dobre i po prostu działał. Uzdrowił fizycznie, psychicznie i duchowo. Uzdrowienie fizyczne: zaraz po rekolekcjach, nawet nieproszony, sprawił dla nas wielki cud uzdrowienia fizycznego z nowotworu naszej drugiej córeczki. Narośl, która rosła jej przez półtora roku, w ciagu jednej doby zaraz po rekolekcjach zniknęła i operacja nie była już potrzebna. W ciągu następnych miesięcy okazało się, że mój teść jest chory na 
nowotwór z przerzutami do kości. Jedyna rada specjalistów to leczenie paliatywne i wyrok - zostało pół roku życia. Pan Bóg wkroczył i uzdrowił: przerzuty się cofnęły i tata zachował życie. I choć to niewiarygodne, wiem, że dla Pana Boga nie ma rzeczy niemożliwych. Również moja żona zachorowała na nowotwór, a Pan Bóg w swej łaskawości również ją uzdrowił. Ktoś może powiedzieć, nie, to nie możliwe, a jednak - jesteśmy namacalnym przykładem wielkości Boga. Uzdrowienie psychiczne i duchowe: od momentu wspomnianych rekolekcji do dziś nasza wiara wzrasta. Pan nas do siebie przyciąga, zachęca do głębszej relacji. Leczy nasze zranienia z przeszłości, uwalnia $\mathrm{z}$ grzechów (w tym grzechów ciężkich popełnianych latami), uwalnia od „starych” nas, zabierając przekonanie o własnych możliwościach, uzdrawiając ze złości, agresji, kłótliwości, buntów.

Dziś jest obecny w naszym codziennym życiu. Nie tylko w niedzielę czy na obrazku na ścianie, ale realnie w każdej chwili dnia i nocy. Każdą decyzję konsultujemy wspólnie, prosząc o rozeznanie, znak, słowo. I widzimy, że to jest dobre.

\section{Wspólnota}

Dzisiaj wiemy, że wszystko, co mamy i kim jesteśmy, zawdzięczamy Bogu. Dużo dostaliśmy, a plany Boga są jeszcze wspanialsze. Sami możemy niewiele, ale w grupie jesteśmy silniejsi. Dlatego od początku przylgnęliśmy do wspólnoty Jeshua, w której dzięki spotkaniom i rekolekcjom Pan Bóg kształtował nas na nowo - nas jako odrębnych ludzi - jednostki. Z czasem powstał pomysł kształtowania się wspólnie - jako małżeństwa i rodziny. I tak powstała decyzja, aby powołać do życia wspólnotę rodzin Nazaret. Przykład i świadectwo to doskonały sposób na to, aby inni również się przyłączyli. Wzrostowi w tej wspólnocie towarzyszy wielka łaska i błogosławieństwo Boże - w ciaggu niespełna 1,5 roku funkcjonowania 
we wspólnocie, mamy już blisko 40 małżeństw z dziećmi. Ogromną radość daje widok innych rodzin i ich zmian, które się dokonują z pomocą Bożą niemal na naszych oczach.

Przykład idzie z góry, po nas był czas na nasze dzieci. Zależało nam, aby nasze dzieci widziały inne, normalne życie - po Bożemu. Aby mogły się bawić i wzrastać z rówieśnikami o podobnych wartościach. Aby widziały, że Bóg jest wszechobecny, wszyscy o Nim wiedzą i wszyscy o Nim mówią.

\section{Przyszłość}

Jesteśmy szczęśliwą rodziną. Pan nam błogosławi. Jest super, czasami tylko trochę trudno. Ale co by się nie działo, to przejdziemy przez to wszystko cało i zdrowo tylko wtedy, kiedy będziemy się trzymać razem - jako małżeństwo, jako rodzina, jako katolicy. Przyznałem się do Boga, a Bóg przyznał się do mnie. Mam nadzieję, że to dopiero początek wspólnej drogi.

Anna i Piotr Zworscy 


\section{Aneks 1.}

\section{Teresa Kapela}

\section{Europejskie federacje stowarzyszeń rodzinnych}

Pomimo, iż rodzina należy do kwestii nie podlegających prawodawstwu unijnemu, to jej znaczenie jest coraz mocniej akcentowane w Europie, a decyzje podejmowane w Brukseli mają bezpośredni wpływ na jej losy. Widzi to wyraźnie szereg stowarzyszeń rodzinnych starających się wnieść podejście do problemów społecznych z punktu widzenia poszczególnych rodzin.

COFACE (Confederation of Family Organisations in the EU - Konfederacja Stowarzyszeń Rodzinnych w UE)

Najszerszą federacją stowarzyszeń rodzinnych jest COFACE, stawiające sobie za cel obronę interesów każdej rodziny. Jest organizacją pluralistyczną grupująca ponad 50 rożnych stowarzyszeń. Nie próbuje definiować rodziny, ale szuka rozwiązań problemó w dotykających potrzeb wszystkich rodzin, również rodzin w specyficznych sytuacjach: z dziećmi niepełnosprawnymi, mniejszości narodowych, samotnych rodziców.

Polityka rodzinna, to nie tylko wspieranie samych rodzin, ale tworzenie środowiska, w którym rodziny mają możliwość wyboru sposobu funkcjonowania, w którym maksymalnie podkreśla się godność rodziny. Tak definiował COFACE jej długoletni dyrektor na ostatniej konferencji „Przyszłość rodzin” (Bruksela 2011): COFACE wspótpracuje ze wszystkimi organami Unii Europejskiej, bierze czynny udziat w pracach $i$ dialogu, podejmuje prace $w$ pięciu głównych działach:

- Polityki rodzinne i społeczne;

- Polityki przeciwdziałające wykluczeniu społecznemu - włączające osoby niepełnosprawne, niesamodzielne i ich rodziny; 
- Problemy dotyczące ochrony konsumenta, zdrowia i usług i zrównoważonego rozwoju;

- Problemy kształcenia i nowych technologii, informatyzacja komunikacji;

- Wymiana doświadczeń i informacji, pogłębienie kompetencji.

FAFCE (Fédération des Associations Familiales Catholiques en Europe - Federacja Stowarzyszeń Rodzin Katolickich w Europie)

Federacja stowarzyszeń katolickich obchodziła niedawno dwudziestolecie swojej działalności. Od trzech lat ma swoją stałą siedzibę w Brukseli przy Konferencji Episkopatów Europejskich. Nowe wyzwania przyniosło rozszerzenie Unii Europejskiej. Integracja 75 milionów osób nie może się odbyć bez zaangażowania w nia rodzin. Europa środkowa i wschodnia potrzebuje naszej chrześcijańskiej solidarności. FAFCE podejmuje działania na szczeblu europejskim na rzecz uznania i docenienia wartości rodziny i jej miejsca w społeczeństwie. Pilnujemy, aby każde prawo stanowione na szczeblu europejskim było egzaminowane pod katem skutków dla rodziny. Zależy nam, aby organizacje rodzinne nowo przyjętych państw podjęty wspótpracę z nami. Sa już naszymi członkami organizacje rodzinne z Czech, Stowacji i Wegier. Naszym celem jest dotarcie do wszystkich krajów, aby stworzyć petna strukture stowarzyszeń rodzin katolickich, aby wzmocnić wptyw organizacji rodzinnych na poziomie narodowym i europejskim na wszystkie decyzje dotyczace polityki rodzinnej. W 25 krajach Unii Europejskiej żyje 239 miliony katolików.

Jedna $\mathrm{z}$ szerokich akcji protestacyjnych przeprowadzonych przez tę organizację, to protest przeciwko praktyce „Handel pracujących w niedziele”. Powody naszego protestu: powoduje on rozmijanie się dzieci, które mają wolne, i rodziców, którzy pracujaj podważa prawo do wolnej niedzieli jako czasu poświęcanego rodzinie, przyjaciołom, jest przeszkodą w praktykach religijnych. Ogłoszono stosowną deklarację - problem ten szczególnie dotyczy nowo przyjętych państw do UE. 
ELFAC (The European Large Families Confederation Europejska Konfederacja Rodzin Wielodzietnych)

Reprezentuje 50 milionów osób żyjących w rodzinach wielodzietnych Europy. Głównym celem ELFAC jest promowanie i popieranie wartości, jakie reprezentuje rodzina, oraz uzyskanie prawnej ochrony rodzin wielodzietnych w całej Europie. Nie domaga się specjalnych praw dla rodzin wielodzietnych, ale sprawiedliwego traktowania. Chcemy, żeby wszyscy mogli mieć tyle dzieci, ile chca, bez dyskryminacji i z takimi samymi szansami. Chcemy przekonywać władze i społeczeństwo, że duże rodziny to nie problem, że duże rodziny to rozwiazanie. Dla promowania wyznawanych wartości, ELFAC organizuje konferencje i seminaria oraz wydaje szereg publikacji. ELFAC - Europejska Konfederacja Dużych Rodzin została formalnie ukonstytuowana w Lizbonie 27 marca 2004 r., zrzeszając Związki Dużych Rodzin z całej Europy. Pomysł stworzenia ELFAC powstał w trakcie I Europejskiej Konferencji Dużych Rodzin, która miała miejsce w 2002 r. w Madrycie. Spotkanie założycielskie ELFAC miało miejsce przy okazji II Europejskiej Konferencji Dużych Rodzin w Lizbonie w 2004 r. W tym roku spotkanie miało miejsce w Estonii. Celem konfederacji jest reprezentowanie społecznych i ekonomicznych interesów rodzin z dziećmi, a w szczególności dużych rodzin, jako najbardziej odpowiedniego środowiska dla wychowywania dzieci, wprowadzania ich do społeczeństwa i zapewniania wzajemnego oparcia i solidarności pomiędzy pokoleniami. Ważna jest również współpraca w celu obrony i ulepszania praw przyznanych dużym rodzinom przez europejskie ustawodawstwo. W skład federacji wchodzi w chwili obecnej 17 krajów, w tym - od momentu powstania w 2007 - ZDR 3+.

FEFAF (Fédération Européenne Des Femmes Actives Au Foyer - Europejska Federacja Osób Aktywnych w Domu)

Obserwatorem i uczestnikiem prac w Brukseli jest również FEFAF. Europejska Federacja Osób Aktywnych w Domu FEFAF jest federacją osób, które za przestrzeń 
swojej pracy przyjmują dom i obowiązki opiekuńcze. W ramach ewolucji rynku pracy coraz mniej jest zauważana praca w domu, pomimo, że według obliczeń ekonomistów ma 30\% -50\% wkładu w PKB. Nie jest mimo to uwzględniana $\mathrm{w}$ rachunkach ekonomicznych i często także $\mathrm{w}$ rozwiązaniach systemowych. Podział pracy był jednym $z$ elementów postępu, wobec tego powstaje pytanie, dlaczego wyklucza się pracę wychowawczą i opiekuńczą rodziców? FEFAF podejmuje te zagadnienia. W Polsce, we współpracy z FEFAF, powstał ciekawy raport „Zrobione-zapłacone". W 2011 r., w ramach roku wolontariatu, w Brukseli miała miejsce konferencja o „pracy niewidzialnej”, podkreślająca jej ogromne znaczenie i nieodzowność.

WFO (World Family Organisation - Światowa Organizacja Rodzin)

W Europie działa również sekcja Światowej Organizacji Rodzin, której przewodniczącą jest dłuższy czas Brazylijka, która w latach 70-tych studiowała w Polsce. W 2007 roku miał miejsce w Warszawie międzynarodowy szczyt WFO. Polskim organizatorem była Pani Jolanta Kwaśniewska. 


\section{Aneks 2.}

Kard. Andre Vingt Trois, Rodzina-szczęście, które trzeba zbudować, przemówienie wygłoszone podczas Kongresu Rodzin w Mediolanie 1-9.06.2012,

$<$ http://www.paris.catholique.fr/Enseignement-du-Cardinal-Andre,23398.html>, [tłum. T. Kapela].

\section{Drodzy Przyjaciele,}

jestem szczęśliwy, że dana jest mi okazja zwrócenia się do Was. Chciałbym zacząć od zwrócenia waszej uwagi na sytuację paradoksalna, a jednocześnie bardzo wymowna, dotyczącą świadomości naszego społeczeństwa. Dziś we Francji jest oczywiste, że rodzina jest rzeczywistością jednogłośnie podkreślaną: wszyscy oczekują wiele od swojej rodziny, każdy życzyłby sobie udanego życia rodzinnego i liczy na to, że rodzina będzie ważnym źródłem wsparcia. Ale i to jest źródłem paradoksu: oczekiwania wzrastają w miarę rozsypywania się rzeczywistej rodziny. A więc rodzi się pytanie, czego dotyczą te oczekiwania? Wydaje się, że wszyscy marzą o posiadaniu silnej rodziny, która dawałaby schronienie, ale nie stawiają sobie pytania, jakie warunki należy spełnić, aby taka rodzina mogła istnieć.

Jednocześnie znajdujemy się w czasie trudności ekonomicznych, wielu młodych czeka długo na znalezienie zatrudnienia i możliwość stabilizacji. Często przez długie lata są zależni od swoich rodziców i swoich rodzin. Ta niepewność ekonomiczna wzmacnia również potrzebę wsparcia, pomocy i ochrony - rodzina wydaje się być dobrym parasolem. Pozostaje problemem, iż rodzina - wykorzystana i po przekształceniach - nie jest już parasolem, a jedynie parasolką nie dającą schronienia wobec nadchodzącej burzy. Wobec tych wszystkich oczekiwań, musimy się zastanowić, jak można sprawić, aby te wszystkie oczekiwania stawiane rodzinie były możliwe do spełnienia. Chcę zaproponować trzy płaszczyzny odniesienia, które mogą być interesujące dla rodzin obecnie i w przyszłości. 
Rodzina wymaga pracy. Istnienie rodziny wymaga zainwestowania sił i środków, a może należy powiedzieć pracy. Nie mówię o tym, że rodzina jest zapleczem do odzyskania sił dla tych, którzy pracują zawodowo. To samo życie rodzinne wymaga nakładów pracy. Musimy podjąć refleksję, jak zmagać się z zagrożeniami, którym rodzina jest poddana, jak budować rodzinę pomimo ataków, jakie ją spotykają.

Nasz Kościół we Francji od dziesięcioleci podejmuje wiele działań w tym kierunku. Antoine Renard przypomniał stulecie działalności Stowarzyszeń Rodzin Katolickich. Cały dwudziesty wiek był naznaczony inicjatywami, aby wspierać życie małżeńskie, rodzinne, rodzicielskie. Stopniowo zauważaliśmy, że przygotowanie do tych ról jest konieczne, przestało być instynktowne. (Bycie rodzicami wymaga lektury, która zresztą buduje fortuny wydawców). Myślę również o ruchach rodzinnych, grupach przygotowań do ślubu, o wszystkich tych, którzy tak masowo uczestniczą w duszpasterstwie, wspierając Kościół, i pracują w służbie rodziny, małżonków, dzieci i młodzieży. Rozbudowało się duszpasterstwo rodzin, mające służyć centralnemu powołaniu małżeństwa, jakim jest budowanie rodziny.

Ażeby lepiej zrozumieć naturę tej pracy na rzecz rodziny, musimy zauważyć, że wiek XX przyniósł zasadniczą zmianę $\mathrm{w}$ rozumieniu rodziny: ze zjawiska oczywistego stała się zjawiskiem zadanym. Wiek temu, a może i pół, rodzina stanowiła oczywistość nie kwestionowaną i nie podlegającą dyskusji w życiu społecznym. Tak jak nie zastanawiamy się nad oddychaniem, pomimo, że wszyscy cały czas oddychamy, rodzina z kilkoma rzadkimi wyjątkami stanowiła element życia, nie podlegający refleksji. Rodziliśmy się w rodzinie, tworzyliśmy rodzinę, zawierając związek małżeński, powiększaliśmy rodzinę, rodząc kolejne dzieci, i jakoś życie się toczyło pośród codziennych zmartwień. W życiu małżeńskim stawialiśmy na porozumienie. Cieszyliśmy się, gdy wszystko się układało, martwili, gdy było trudniej. W kwestiach wychowania 
dzieci przejmowaliśmy zasady rodziców, nie zastanawiając się zbytnio nad teoriami wychowawczymi, w każdym razie większość z nas. Solidarność międzypokoleniowa nie stawiała specjalnych wyzwań: życie trwało krócej niż dziś, pokolenie starszych było mniej liczne, młodzież bardzo liczna. Przodek miał 20-30 osób, które dzieliły się opieka, gdy tymczasem obecnie jest odwrotnie. Są liczne osoby mające pod opieką 4-8 osób z pokolenia dziadków i pradziadków. Obecnie relacje międzypokoleniowe nie są zdominowane przez młodych, dynamicznych, raczej są przejmowane przez starsze pokolenie, które przechyla szalę na swoją stronę. To zresztą nie jest dramatem i nie ogranicza szczęśliwego życia, ale jest to zmiana warunków życia, sposobu patrzenia na świat i organizowania swojego otoczenia.

Stopniowo zdaliśmy sobie sprawę, ze rodzina nie jest już instytucją mocno wspieraną i zintegrowaną ze społeczeństwem, której wystarczą nasze uczucia i hojność. Nie jest już dobrze budowanym domem, w który każdy inwestuje swoje zdolności i umiejętności, bez konieczności zastanawiania się nad funkcjonalnością architektury. Obecnie budynek stracił kształt. Poszczególne elementy, które składały się na rodzinę, stały się wymienne. Małżeństwo często nie jest już wzajemnym zaangażowaniem się mężczyzny i kobiety na trwałe i podjęciem wychowania dzieci, które będą mieli. Charakter wyłączny i trwały nie jest dziś podstawowy, podobnie jak chęć, a wręcz myśl o posiadaniu dzieci. Inne warunki tworzenia rodziny są kwestionowane teoretycznie, jak na przykład związek mężczyzny i kobiety. I - jak wiemy - są silne tendencje, aby ten teoretyczny postulat stał się możliwy w praktyce.

Żyliśmy w stanie równowagi i jasnej wizji instytucji, która wspierała osobiste zaangażowanie i podtrzymywała tych, którzy napotykali trudności. Obecnie każda i każdy jest zapraszany nie aby wejść w projekt, który jest jasno zdefiniowany, ale aby podjąć budowanie tej instytucji, aby stała się pewna. Mamy wciąż gdzieś zakodowany projekt, ale nikt nie znajduje go już wybudowanym. Dla każdego 
zostaje praca nad zbudowaniem rodziny, nad znalezieniem materiałów, zakasaniem rękawów i zbudowaniem domu, w którym przyjdzie mu żyć. Jak każda praca i ta praca jest męcząca, wymaga czasu, energii i środków. W tych, którzy wyobrażają sobie rodzinę jako port pomiędzy innymi wyzwaniami, zdumienie budzi konieczność podjęcia tego wysiłku. Ten, kto liczył na oparcie w rodzinie, nie jest gotowy na to, żeby rodzina opierała się na nim!

Jesteśmy więc w okresie kryzysu, nie w sensie negatywnym tego słowa kryzysu-upadku, ale w sensie konieczności podjęcia decyzji. Zadanie nie polega na dołączeniu do batalionu normalnych rodzin, ponieważ nie wiadomo, gdzie można by go znaleźć! Pytanie jest następujące: czy chcę stworzyć rodzinę, jak się do tego zabrać, jaką cenę jestem gotowy zapłacić? Ile czasu, jaki wysiłek jestem gotów poświęcić, jak podejmować relacje przebaczenia i miłosierdzia, aby rodzina istniała? Jesteśmy więc daleko od stereotypu, który gdzieś istnieje w podświadomości, mimo że całkowicie rozmija się z rzeczywistością - rodzina jako miejsce odpoczynku dla wojownika. Obecnie wojownik, który równie często jest wojowniczka, jest pracownikiem, który cały dzień podlega napięciom i konfliktom. Kiedy wraca do domu, prawdopodobnie liczy na spokój, odpoczynek, bez konieczności planowania wieczorów i weekendów, myślenia, co trzeba powiedzieć lub zrobić. Tymczasem, życie rodzinne musi być budowane, podtrzymywane, przemyślane i nieustannie tworzone..., nie można odpocząć, trzeba dalej zadawać sobie trud. 



$$
28
$$

